Installation Technology Transfer Program

\title{
Development of Army Facility Functionality Assessment Criteria and Procedures
}

Michael N. Grussing, Lance R. Marrano,

September 2010

and Matthew C. Walters 



\section{Development of Army Facility Functionality Assessment Criteria and Procedures}

Michael N. Grussing, Lance R. Marrano, and Matthew C. Walters

Construction Engineering Research Laboratory

U.S. Army Engineer Research and Development Center

2902 Newmark Drive

Champaign, IL 61822

Final report

Approved for public release; distribution is unlimited.

Prepared for U.S. Army Corps of Engineers

Washington, DC 20314-1000

Under Project FY09-38, "Functionality of Existing Buildings" 


\begin{abstract}
This report describes the process for identifying building functionality criteria and assessing the functional capability of Army facility real property. The criteria are to be incorporated into a process to measure the functionality and performance of existing Army buildings for support of sustainment, restoration, and modernization (SRM) decisions. This process is based on a general functionality assessment framework developed for the BUILDER ${ }^{\text {TM }}$ Sustainment Management System (SMS). BUILDER includes an algorithm and procedure for calculating a building functionality index (FI) based on a predefined set of criteria. The FI indicates any decrease in building performance due to technical obsolescence, user requirement changes, or new codes or standards. These generalized criteria are supplemented with Army-specific criteria based on current Army Standards and Army Standard Designs. In addition, facility functionality-related criteria from the Army Installation Status Report for Infrastructure (ISR-I) are identified and mapped to BUILDER criteria. This linkage provides a way to exchange information between ISR-I and BUILDER, creating the technical basis for an integrated facility management environment. This report presents the results of the work and offers recommendations pertaining to future integration efforts.
\end{abstract}




\section{Executive Summary}

\section{Background}

The Assistant Chief of Staff for Installation Management (ACSIM) is responsible for developing and publishing Army Facility Standards, and the U.S. Army Corps of Engineers (USACE) Centers of Standardization (COS) are responsible for implementing them in Army Standard Designs. These documents specify requirements and features for a newly constructed facility, but a vast majority of existing Army facilities were not built to comply with them. Nevertheless, it is necessary to evaluate the performance of existing facilities against the current facility requirements in order to understand how these facilities can support the Army's current and future projected technology and weapons systems. The Army's process to assess the condition, performance, and readiness of facilities is the Installation Status Report for Infrastructure (ISR-I). While the ISR-I criteria have been updated to distinguish between condition-related quality issues and mission-related issues, current Army Standards and Standard Designs are not fully incorporated into these mission criteria.

The BUILDER ${ }^{\circledR}$ Sustainment Management System (SMS) ${ }^{*}$ has a generalized methodology to assess and measure the functional performance of a building. This functional performance relates to how effectively, safely, and efficiently a building performs its mission at any time during its life cycle. A building's functional performance state relates to the facility's suitability to function as intended and required for the mission. Changes in functionality are driven by factors such as user requirements, building codes, or obsolescence of materials and technology. Loss in functionality is qualitatively described through characteristics making a building less suitable for its mission as compared with a new facility specifically constructed for the same mission. By integrating the BUILDER functionality framework, the ISR-I mission criteria, and the Army design standards, an ISR-I facility assessment can identify the gaps between an existing facility and newly constructed facility built to the latest standard. This integration also allows assessment criteria from the ISR-I process to feed into BUILDER to calculate a Building Functionality Index.

* BUILDER is a registered trademark of the Department of the Army, Washington, DC. 


\section{Objective and approach}

The objective of this project was to identify the specific building configuration criteria embodied in Army Standards and Standard Designs to serve as the mission-related criteria for ISR. This project categorized the criteria for four Tier 1 mission-critical facility types: the Tactical Equipment Maintenance Facility (TEMF), the Company Operations Facility (COF), the Battalion Headquarters Facility, and the Brigade Headquarters Facility. These criteria were then organized and linked to BUILDER functionality subissues and ISR-I mission criteria, and a data element map was created. Guidance for incorporating information and assessment criteria was developed as part of this project. In addition, guidance was developed to explain how this information is incorporated into Army facility management systems.

\section{Benefits}

Inappropriate building layout, poorly chosen materials or equipment, code violations, etc., interfere with a building's capability to support its mission requirements. While the ISR-I assessment process attempts to identify facility requirements affecting readiness and mission, a formalized process to incorporate current Army Standards and Standard Designs into the assessment does not exist. The development of a formalized process for that purpose makes it possible for Army installations to evaluate their buildings and collect data relevant to current facility requirements and allows consistent comparison against the latest Army Standards and Standard Designs. In addition, the information collected for the ISR-I can feed into the BUILDER functionality assessment framework to calculate a Functionality Index value. It provides an impartial metric for justifying modernization needs and directly supports Goal 1 of the 2007 Defense Installations Strategic Plan (2007 Defense Installations Strategic Plan, http://www.acc.osd.mil/ie/download/DISP2007_final.pdf, p 6): to locate, size, and configure defense installation assets to meet the required capabilities of military forces. The Functionality Index promotes better targeted revitalization of existing inventories by identifying where SRM or facility repurposing is cost effective as compared with new construction. Finally, the ISR-I information serves as a sort of user manual for the facility, training the occupants on the latest features of their newly constructed facility to better understand how the facility was designed to be used. 


\section{Costs}

Integration of the procedure into the existing Army process will result in at most incremental additional data collection effort.

\section{Implementation and maintenance requirements}

Army ISR-I criteria require modification to standardize the missionrelated facility criteria and incorporate current Army Standards and Standard Design requirements. These modifications make it possible to assess facilities of different ages in comparison with a common and current baseline.

When the ISR-BUILDER data exchange linkage is in place, maintenance of the data in the BUILDER system may be accomplished during the normal ISR-I inspection process, by in-house personnel as usual, or through a contract work group. A training program will be necessary to ensure the accurate collection of facility data during assessment. Training consists of entering data into system, performing facility analysis, and running reports.

Finally, to address security and information assurance issues, the BUILDER SMS system requires Army and DoD Information Technology (IT) accreditation. BUILDER went through the Department of Defense Information Assurance Certification and Accreditation Process (DIACAP) in J une 2009, and was granted an Authority to Operate (ATO) by the U.S. Army Information Systems Engineering Command in March 2010. Although the Army demonstration database for BUILDER is hosted on servers at ERDC-CERL, eventually the servers must be moved to an Armycentral location to ensure optimized connection times across installations and to provide helpdesk support. This activity leverages the Army enterprise contract (CHESS) for services, per directive by the Assistant Chief of Staff for Installation Management (ACSIM), thereby lowering operating costs.

\section{Recommendation}

The research team recommends the ISR-I mission criteria be modified and appended to include facility-specific Army Standards and Standard Designs, as identified in the appendices to this report. In addition to including the latest standards as a baseline, such modifications will allow 
BUILDER to import data from ISR-I component ratings to initially populate the installation database and then use that information to calculate a Functionality Index value. The technology to import these data was implemented as a data map, developed as part of this project, that links BUILDER functionality information to ISR-I criteria and Army Standard Design criteria. 


\section{Table of Contents}

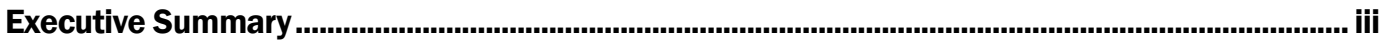

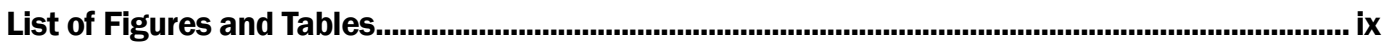

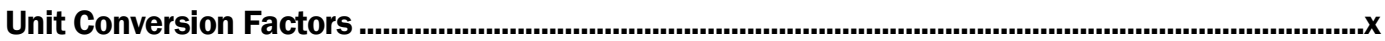

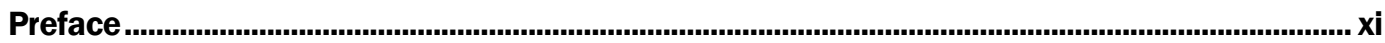

1 Introduction

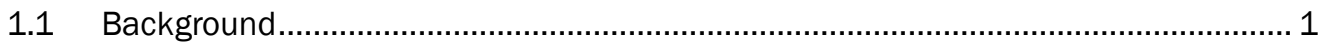

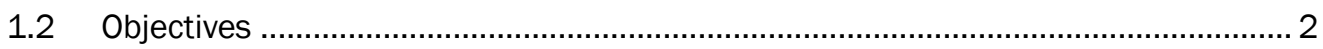

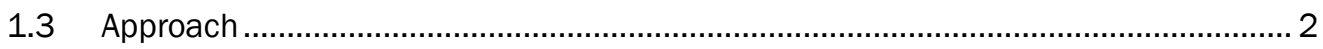

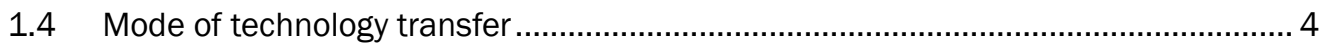

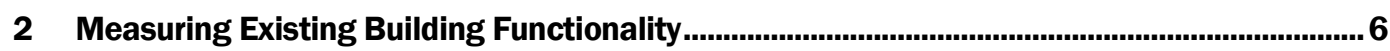

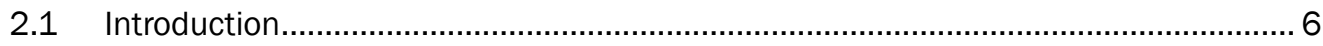

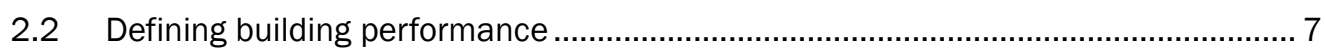

2.3 Condition state ............................................................................................ 7

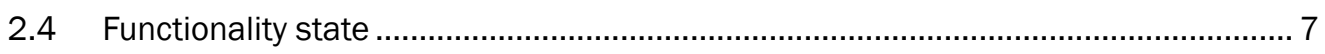

2.5 Functionality assessment framework ................................................................. 8

2.6 Development of functionality deduct value models .............................................. 12

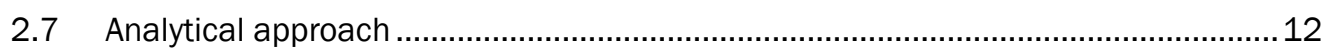

2.8 Adjusting for impact of multiple functionality issues............................................ 14

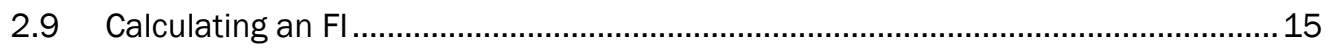

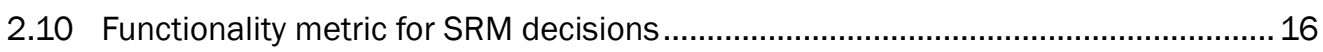

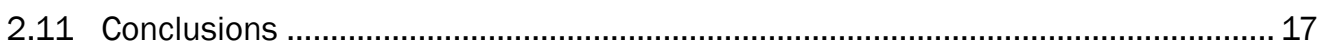

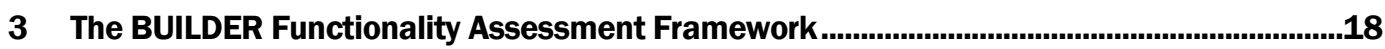

3.1 Functionality assessment overview................................................................ 18

3.2 Overview of the first tier of assessment............................................................... 19

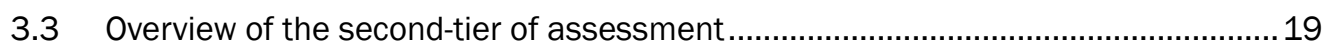

3.4 Functionality Index computation overview ..........................................................20

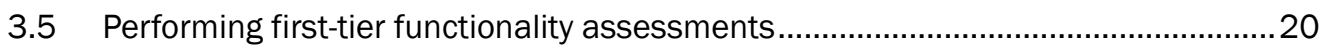

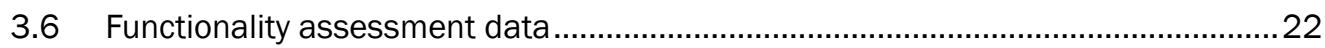

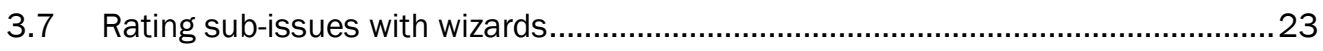

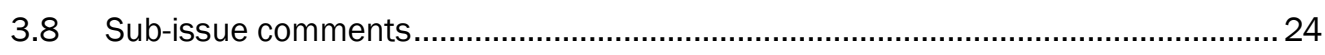

4 Linkage of Army Standard Design Criteria to the FI Assessment Framework .....................25

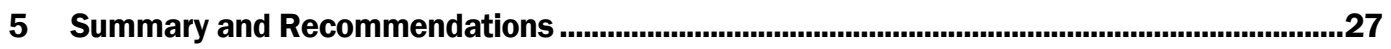

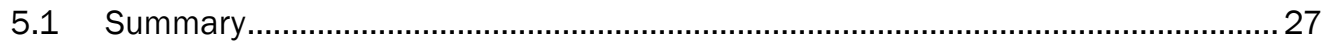

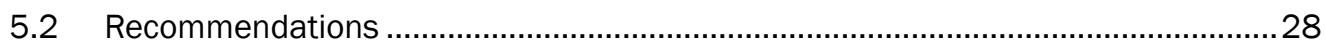

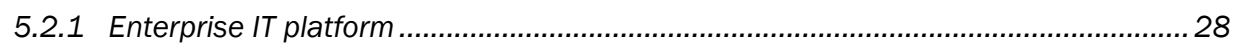

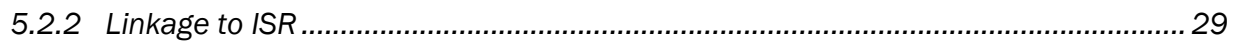


5.2.3 Integration with the General Fund Enterprise Business System (GFEBS).................29

5.2.4 Linking with Army Mapper ................................................................................. 30

References ....................................................................................................................................31

Acronyms and Abbreviations ....................................................................................................32

Appendix A: BUILDER SMS Building Level Functionality Issues....................................................34

Appendix B: BUILDER Functionality Index Interval Definitions...................................................36

Appendix C: Example Building Functionality Assessment Sheet ...............................................37

Appendix D: Army Standard Design Criteria for Brigade Headquarters Facility.........................41

Appendix E: Army Standard Design Criteria for Battalion Headquarters Facility..........................50

Appendix F: Army Standard Design Criteria for Company Operations Facilities (COF)................56

Appendix G: Army Standard Design Criteria for Tactical Equipment Maintenance Facilities (TEMF)....................................................................................................................65

Appendix H: User Input Design Issues for Tactical Equipment Maintenance Facilities

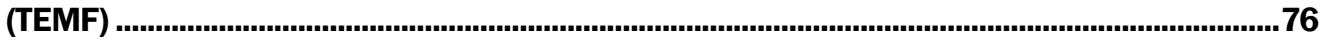

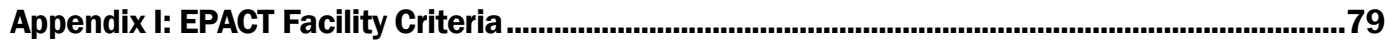

Appendix J: BUILDER FI Interval Mapping to ISR-I Definitions...................................................8

Appendix K: Army ISR-I Mapping to BUILDER Functionality Criteria, Administrative Facilities................................................................................................................................82

Appendix L: Army ISR-I Mapping to BUILDER Functionality Criteria, Maintenance Facilities...

Appendix M: Army ISR-I mapping to BUILDER Functionality Criteria, Unit Operation Building

Appendix N: Army ISR-I Mapping to BUILDER Functionality Criteria, Warrior Transition Units.

Report Documentation Page 


\section{List of Figures and Tables}

\section{Figures}

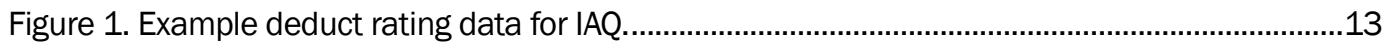

Figure 2. Adjusted deduct factor for multiple issues............................................................................14

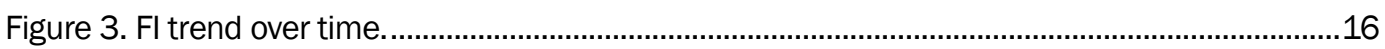

Figure 4. Functionality assessment hierarchy. ...................................................................................19

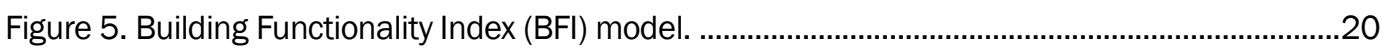

Figure 6. Access to the BUILDER functionality assessment module...............................................21

Figure 7. BUILDER functionality assessment screen. ....................................................................21

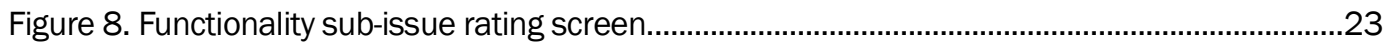

Figure 9. Example Army Standard Design Criteria......................................................................26

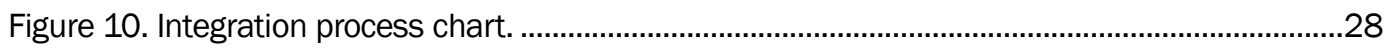

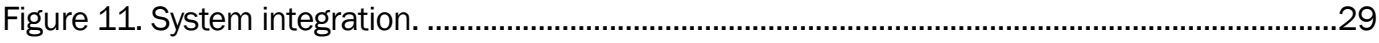

\section{Tables}

Table 1. Functionality Index interval descriptions...............................................................................

Table 2. Functionality issue categories. .........................................................................................10 


\section{Unit Conversion Factors}

\begin{tabular}{|c|c|c|}
\hline Multiply & By & To Obtain \\
\hline Acres & $4,046.873$ & square meters \\
\hline cubic feet & 0.02831685 & cubic meters \\
\hline cubic inches & 0.00001638706 & cubic meters \\
\hline degrees (angle) & 0.01745329 & radians \\
\hline degrees Fahrenheit & $(5 / 9) \times\left({ }^{\circ} \mathrm{F}-32\right)$ & degrees Celsius \\
\hline degrees Fahrenheit & $(5 / 9) \times\left({ }^{\circ} \mathrm{F}-32\right)+273.15$ & kelvins \\
\hline Feet & 0.3048 & meters \\
\hline gallons (U.S. liquid) & 0.003785412 & cubic meters \\
\hline horsepower (550 ft-lb force per second) & 745.6999 & watts \\
\hline Inches & 0.0254 & meters \\
\hline kips per square foot & 47.88026 & kilopascals \\
\hline kips per square inch & 6.894757 & megapascals \\
\hline miles (U.S. statute) & 1.609347 & kilometers \\
\hline pounds (force) & 4.448222 & newtons \\
\hline pounds (force) per square inch & 0.006894757 & megapascals \\
\hline pounds (mass) & 0.4535924 & kilograms \\
\hline square feet & 0.09290304 & square meters \\
\hline square miles & $2,589,998$ & square meters \\
\hline tons (force) & $8,896.443$ & newtons \\
\hline tons $(2,000$ pounds, mass $)$ & 907.1847 & kilograms \\
\hline Yards & 0.9144 & meters \\
\hline
\end{tabular}




\section{Preface}

This study was conducted for the U.S. Army Assistant Chief of Staff for Installation Management (ACSIM) under Installation Technology Transfer Program (ITTP) Project FY09-38, "Functionality of Existing Buildings." The technical reviewer for U.S. Army Installation Management (IMCOM) was Samuel Morris, Chief, Engineering Division, White Sands Missile Range; and the technical reviewer for ACSIM was Philip Columbus, DAIM-ODF.

The work was performed by the Engineering Processes Branch (CF-N) of the Facilities Division (CF), U.S. Army Engineer Research and Development Center - Construction Engineering Research Laboratory (ERDCCERL). The ITTP Program Manager was Kelly M. Dilks, CEERD-CF-N. At the time of publication, Donald K. Hicks was Chief, CEERD-CF-N; L. Michael Golish was Chief, CEERD-CF; and Martin J . Savoie was the Technical Director for Installations, CEERD-CV-ZT. The Deputy Director of ERDC-CERL was Dr. Kirankumar Topudurti and the Director was Dr. Ilker Adiguzel.

COL Gary E. J ohnston was the Commander and Executive Director of ERDC, and Dr. J effery P. Holland was the Director. 



\section{Introduction}

\subsection{Background}

Army installations and infrastructure will require reconfiguration to comply with new Army policies related to transformation and modernization, realignment and joint basing, and federal facilities energy initiatives. Inappropriate building layout, poorly chosen materials or equipment, code violations, etc., interfere with a building's capability to support these mission requirements. Although the Installation Status Report for Infrastructure (ISR-I) is currently being restructured to more clearly distinguish mission-related issues from quality-related issues, a formalized process to incorporate Army design standards into the mission assessment criteria for the ISR-I does not exist.

The BUILDER ${ }^{\circledR}$ Sustainment Management System (SMS) ${ }^{*}$ has a generalized methodology to assess and measure the functional performance of a building. This functional performance relates to how effectively, safely, and efficiently a building performs its mission at any time during its life cycle. A building's functional performance state relates to the facility's suitability to function as intended and required for the mission. Changes in functionality are driven by factors such as user requirements, building codes, or obsolescence of materials and technology. Loss in functionality is qualitatively described through characteristics making a building less suitable for its mission as compared with a new facility specifically constructed for the same mission. By integrating the BUILDER functionality framework with the ISR-I mission criteria and Army design standards, an ISR-I facility assessment can identify the gaps between an existing facility and newly constructed facility built to the latest standard. This integration also allows assessment criteria from the ISR-I process to feed into BUILDER to calculate a Building Functionality Index (BFI).

The BFI provides an objective metric for justifying facility modernization needs. This directly supports goal 1 of the 2007 Defense Installations Strategic Plan - to locate, size, and configure defense installation assets to meet the required capabilities of military forces. The BFI supports better-

\footnotetext{
* BUILDER is a registered trademark of the Department of the Army, Washington, DC.
} 
targeted revitalization of existing inventories by identifying where SRM is cost effective as compared with new construction. Other key policy drivers related to this project include:

- Army Regulation AR 420-1, Defense Readiness Reporting System (DRRS) Requirements for $\mathrm{Q}$ ratings

- Executive Order EO 13327, Federal Real Property Asset Management.

\subsection{Objectives}

The objectives of this project were to identify the specific building configuration criteria embodied in the Army Standards and Standard Designs to serve as the mission-related criteria for the ISR, and to identify methods and practices necessary to implement the criteria with a BFI that can function within the BUILDER SMS environment and support the ISR-I.

\subsection{Approach}

This project categorized Army Standards and Standard Design criteria for four Tier 1 mission-critical facility types: the Tactical Equipment Maintenance Facility (TEMF), the Company Operations Facility (COF), the Battalion Headquarters Facility, and the Brigade Headquarters Facility. The criteria were then organized and linked to BUILDER functionality sub-issues and ISR-I mission criteria, and a data element map was created. Guidance for incorporating information and assessment criteria was developed as part of this project. In addition, guidance was developed to explain how this information is incorporated into Army facility management systems.

The term building performance refers to how effectively, safely, and efficiently a building performs its mission at any time during its life cycle. A building's performance state, which changes during time in service, is reflected by two different indicators: the physical condition state and the functionality state. The physical condition state relates to a facility's general "physical fitness," and the functionality state relates to the facility's suitability to function as intended and required for the mission.

Changes in functionality are driven by factors such as user requirements, building codes, or obsolescence of materials and technology. Loss in functionality is qualitatively described through characteristics that make a building less suitable for its mission versus a new facility specifically constructed for the same mission. A qualitative value for loss of functionality 
is established by identifying the percentage of the building that does not suit the mission well and determining the degree of adverse impact created by those characteristics.

A building-level functionality assessment and indexing approach captures both qualitative issues and quantitative functionality-loss metrics affecting facility performance. This approach considers 14 comprehensive functionality categories, listed below, related to current or future expected user requirements, technical obsolescence, codes, laws, and regulations:

1. Location - suitability of building location for mission performance

2. Building Size/ Configuration - suitability of building size and layout for the mission

3. Structural Adequacy - capability of structure to support anticipated loads

4. Access - capability of building to support entry, navigation, and egress

5. Accessibility - level of compliance with the Architectural Barriers Act (ABA)

6. AT/FP - compliance with DoD antiterrorism/ force protection requirements

7. Building Services - suitability of power, plumbing, telecommunications, security, and fuel distribution systems

8. Comfort - suitability of temperature, humidity, noise, and lighting for occupants

9. Efficiency/ Obsolescence - addresses energy efficiency, water conservation, etc.

10. Environmental/Life-Safety - addresses issues such as asbestos abatement, lead-based paint, air quality, fire protection

11. Missing/Improper Components - availability and suitability of components necessary to support the mission

12. Aesthetics - suitability of interior and exterior building appearance for the mission

13. Maintainability - ease of maintenance for operational equipment

14. Cultural Resources - historic significance and integrity issues impacting utilization and modernization.

The BUILDER SMS provides a generalized framework for structuring a facility functionality assessment. The Assistant Chief of Staff for Installation Management (ACSIM) is responsible for developing and publishing Army Facility Standards, and the U.S. Army Corps of Engineers (USACE) 
Centers of Standardization (COS) are responsible for implementing them in Army Standard Designs. These documents specify requirements and features for a newly constructed facility, providing a baseline from which to evaluate the performance of existing facilities against the latest facility requirements. The Army Standards and Standard Designs make it possible to better understand how the vast portfolio of existing facilities can support the Army's current and future projected technology and weapons systems, and thus they supplement BUILDER functionality criteria and the BFI. Facility functionality-related criteria from the Army Installation Status Report booklets for Infrastructure (ISR-I) are identified and mapped to BUILDER criteria as well. This linkage allows for information to be exchanged between the ISR-I and BUILDER, thus comprising an integrated facility management environment.

\subsection{Mode of technology transfer}

This project incorporates technology into the BUILDER SMS for future use by Army Department of Public Works (DPW) personnel to manage the sustainability and life cycle of building assets. Technology transfer efforts will include:

- development of Army functionality assessment process guidance

- linkage of BUILDER with Army Standards, Standard Designs, and ISRI criteria

- information technology (IT) system integration into the Army facility management process and the corporate data warehouse.

BUILDER is a fully web-based enterprise software platform which currently supports SQL Server 7.0, 2000, and 2005 (including Express Edition). Support for Oracle is also planned for the near future. All user interface elements run in web browsers using standard HTML and J avaScript. The pilot implementation of the BUILDER database is currently hosted on servers located and supported at ERDC-CERL, Champaign, IL. Wide-scale usage of BUILDER at several Army installations will be transitioned to a centralized data server/ support center as appropriate. The configuration provides fast, secure multiuser access and automatic periodic backups of the Army BUILDER database. BUILDER went through the Department of Defense Information Assurance Certification and Accreditation Process (DIACAP) in J une 2009, and was granted an Authority to Operate (ATO) by the U.S. Army Information Systems Engineering Command in March 2010. 
Support to Army BUILDER users requiring access to facility functionality information is provided via email or telephone. This support will be provided by the Army's enterprise contract (CHESS) for services. Technical assistance addresses detailed software and how-to questions, diagnoses problems, and documents software errors or bugs to be communicated to the system developer. Periodic onsite support may be required to configure server and database setup of the BUILDER SMS and coordinate IT integration with other Army facility management systems, including HQIIS, Army Mapper, ISR-I, and GFEBS. Annual user group meetings are planned to help identify and prioritize program enhancements and new features with the input by the user base. 


\section{Measuring Existing Building Functionality}

\subsection{Introduction}

Building assets represent a significant portion of the infrastructure capital held by federal, state, and local agencies, as well as private organizations. In the United States alone, the total value of this building infrastructure capital runs well into the trillions of dollars. For example, the active military services are responsible for nearly 380,000 building facilities, estimated at a Plant Replacement Value (PRV) of $\$ 435$ billion (GAO 2003). In addition to the substantial investment these facilities represent, they also contribute a major role in support of the military's many missions.

Like all infrastructure domains, buildings provide services that enable the performance of processes and missions. When designing a building, the location, materials, and configuration are chosen to best support that purpose under the consideration of cost. As the building operates in service and ages, building materials, components, and systems deteriorate, leading to some less-than-optimal performance. This loss is determined through a condition assessment process and is measured by a condition metric. Building mission performance is also affected by obsolescence, which generally is not a result of condition deterioration. Instead, obsolescence is a result of changes in building user requirements, changes in building technologies, and changes in codes or regulations. For example, as mission and user requirements change, which is likely for permanent facilities, the building's capability to perform a new mission is also affected. This loss is determined through a functionality assessment and is measured by a functionality metric. While building condition is improved through repair and or restoration, an improvement in functionality is accomplished through facility modernization.

A consistent, measurable, and meaningful functionality metric related directly to building performance can help facility managers make more well informed building infrastructure investment decisions. This chapter describes the development of a standard building functionality assessment that produces in a functionality state metric. 


\subsection{Defining building performance}

Building performance is defined as the behavior in service of a building for a specified use at a point in time (ASTM E 1480-92). It encompasses issues of mission support, building safety, resource efficiency, life-safety, etc. The building performance state is dependent on two individual but sometimes linked building attributes: the physical condition state and the functionality state. Together, the functionality index and condition index measures define a comprehensive performance index for the facility.

\subsection{Condition state}

The physical condition state relates the general health of the building. Physical deterioration of the building due to normal aging, excessive or abusive use, or poor maintenance causes a reduction in the building's ability to perform its mission as required. For example, a deteriorated and leaking roof can reduce the building's ability to provide a comfortable, moisture-free environment. Past facility maintenance management research has focused on defining, quantifying, and measuring the condition state of a building in a consistent, objective, and repeatable fashion. One such methodology is the distress survey condition assessment process that produces a Condition Index (CI) metric. The CI relates the condition of building components, systems, and the building as a whole on a 0-100 scale and reflects the presence of distresses adversely affecting the condition of the asset.

\subsection{Functionality state}

The functionality state is related to the building's inherent suitability to provide services for the functions or mission it was designed or is required to support. In theory the functionality state is independent of the condition state; it indicates the capability of a building to perform as required in the absence of all physical condition deterioration. Functionality loss due to an inefficient building layout, improper choice of materials or equipment, code violations, etc., can affect the building's ability to perform mission and meet user requirements. For example, a maintenance shop building that does not have the proper size and configuration to efficiently service current vehicles and equipment is less than fully suitable to perform its mission of supporting vehicle maintenance even if the building is in excellent physical condition. 
Loss of functionality is qualitatively described by identifying issues inherent in the building and its design that lead to some less-than-optimal performance of mission when compared with a newly constructed building designed to incorporate all current requirements for mission support service. To classify the broad range of issues affecting the functionality state, building functionality loss is a result of one of three factors:

1. User requirements. As tenant requirements change, or the underlying designated mission changes, the building's capability to provide service to its users is affected.

2. Codes and regulation. As new building codes, regulations, or organizational policies take effect, the building must be adapted to the changes.

3. Materials and technology. As new technologies improve efficiency, maintainability, and overall performance of buildings, existing building components become obsolete and have lower capabilities in relation to the new baseline.

\subsection{Functionality assessment framework}

The functionality metric proposed here was developed to quantitatively describe the functionality state of a building, or a logical subset of a building such as an area or component. Since functionality is the counterpart to condition in describing total building performance state, for consistency this metric follows the methodology established for the CI. The CI is an ASTM standard for pavement condition measurement, and the procedure has been replicated for building, roof, and railroad track structure condition state measurements (ASTM D 5340-93). All index scales ranges from 100- 0 , with 100 being the ideal state.

In order to measure building functionality, a scale was first defined to correlate varying degrees of qualitative functionality descriptors. This scale is shown in Table 1. (See Appendix B for a full description of this table.) The intervals on the scale are arranged so the degree of functionality loss is proportional to a similar condition loss on the CI scale. The FI scale provides a way to communicate the suitability of the building to provide necessary service in support of its specified mission. 
Table 1. Functionality Index interval descriptions.

\begin{tabular}{|c|c|}
\hline $\mathrm{FI}$ & Building Functionality Description \\
\hline 100 & $\begin{array}{l}\text { No functionality problems exist in building. All user requirements are met, no components are obsolete, and } \\
\text { the building is in full compliance with all codes and regulations. }\end{array}$ \\
\hline $86-99$ & $\begin{array}{l}\text { One or more, up to a very few, non-critical or critical components suffer from varying degrees of functionality } \\
\text { loss; and/or } \\
\text { Up to a small number of components suffer from varying degrees of functionality loss; and/or } \\
\text { One or more areas are experiencing slight functional impairment; and/or } \\
\text { Building, as a whole, is only slightly functionally impaired. }\end{array}$ \\
\hline $71-85$ & $\begin{array}{l}\text { More than a very few, but not many, non-critical or critical components suffer from varying degrees of } \\
\text { functionality loss; or combinations of a few non-critical and critical components suffer from varying degrees } \\
\text { of functionality loss, and/or } \\
\text { Many components are experiencing varying degrees of functionality loss; and/or } \\
\text { One or more areas are experiencing minor functional impairment, and/or } \\
\text { Building, as a whole, is functionally impaired but only to a minor degree. }\end{array}$ \\
\hline $56-70$ & $\begin{array}{l}\text { Many, non-critical and critical components suffer from varying degrees of functionality loss; and/or } \\
\text { Large numbers of components are experiencing varying degrees of functionality loss, and/or } \\
\text { One or more critical areas are experiencing moderate functional loss and other areas may be experiencing } \\
\text { functional loss to a moderate or a lesser degree; and/or } \\
\text { Building, as a whole, is functionally impaired to a moderate degree. }\end{array}$ \\
\hline $41-55$ & $\begin{array}{l}\text { One or more critical areas are experiencing significant functional loss and other areas may be experiencing } \\
\text { functional loss to a significant or lesser degree; and/or } \\
\text { Building, as a whole, is functionally impaired to a significant degree. }\end{array}$ \\
\hline $26-40$ & $\begin{array}{l}\text { One or more critical areas are experiencing extensive functional loss and other areas may be experiencing } \\
\text { functional loss to an extensive or lesser degree; and/or } \\
\text { Building, as a whole, is functionally impaired to an extensive degree. }\end{array}$ \\
\hline $11-25$ & $\begin{array}{l}\text { The majority of areas are experiencing a functional loss to some degree with one or more being severe (total } \\
\text { or nearly so); or } \\
\text { Building, as a whole, is barely able to serve its intended or proposed use. }\end{array}$ \\
\hline $0-10$ & Building is totally unable to serve its intended or proposed use. \\
\hline
\end{tabular}

\section{The FI methodology links the physical observations identified during a} building functional assessment to the aforementioned functionality scale. Building characteristics that adversely affect functionality are generically referred to as issues.* Through literature review and input from building subject matter experts (SMEs), the research identified 14 discrete functionality issue categories related to (1) user requirements, (2) technical obsolescence, or (3) codes, laws, and regulations. The 14 issue categories are listed in Table 2.

\footnotetext{
* In the FI methodology, an issue is defined as one of 14 generalized categories affecting the functionality of a building; a sub-issue is defined as a detailed subordinate issue within any issue category that an assessor uses for rating purposes. The sub-issue pertains to the level at which observable problems are documented.
} 
Table 2. Functionality issue categories.

\begin{tabular}{|l|l|}
\hline Category & Description \\
\hline Location & Suitability of building location to mission performance \\
\hline Building Size/Configuration & Suitability of building/area size and layout for the mission required \\
\hline Structural Adequacy & Capability of structure to support seismic, wind, snow, and mission-related loads \\
\hline Access & Capability of building/area to support entry, navigation, and egress as required \\
\hline Accessibility & Level of compliance with the Architectural Barriers Act \\
\hline AT/FP & Compliance with Antiterrorism/force protection requirements \\
\hline Building Services & Suitability of power, plumbing, telecom, security, and fuel distribution \\
\hline Comfort & Suitability of temperature, humidity, noise, and lighting for facility occupants \\
\hline Efficiency/Obsolescence & Addresses energy efficiency, water conservation, and HVAC zoning issues \\
\hline Environmental/Life-Safety & $\begin{array}{l}\text { Addresses issues such as asbestos abatement, lead paint, air quality, and fire } \\
\text { protection }\end{array}$ \\
\hline Missing/Improper Components & Availability and suitability of components necessary to support the mission \\
\hline Aesthetics & Suitability of interior and exterior building appearance \\
\hline Maintainability & Ease of maintenance for operational equipment \\
\hline Cultural Resources & Historic significance and integrity issues impacting utilization and modernization \\
\hline
\end{tabular}

While these categories provide a general classification of building functionality issues, they do not provide the depth and detail required to appropriately measure functionality loss. Therefore, associated with each functionality issue category are one or more sub-issues. Each sub-issue uniquely describes a building-related problem that is actionable through application of a corrective procedure. For example, the Environmental / Health category includes sub-issues for asbestos, air quality, radon, lead paint, etc. Each of these sub-issues individually affects the functionality of the building to support mission in a safe and efficient manner for its occupants.

Each sub-issue has a specific definition and visual or technical criteria to be observed. The definition and criteria provide a building technician or professional assessing the building functionality with a set of instructions for evaluating whether a particular sub-issue is affecting the building. Using the standardized list of building sub-issues and the explicitly stated criteria for each sub-issue, the functionality evaluation procedure is a consistent and repeatable process. Sub-issues are detailed in Appendix A.

In addition to identifying sub-issues affecting a building's functionality, the assessment also determines a level of "severity." The severity indicates the effect a sub-issue has on operational, mission, and life safety service 
capabilities. Three severity categories are distinguished using a Green / Amber / Red convention and are each discussed below:

1. Green - fully complies with the requirements of the sub-issue; it does not affect suitability to perform mission.

2. Amber - the issue is evident, affecting suitability to perform mission, but not to as significant a degree as described by Red.

3. Red - the issue is evident, greatly affecting suitability and capability to support performance of mission, and it creates significant risk in terms of life-safety and mission accomplishment.

In addition to identifying and recording the present functionality issues, the amount or density of each sub-issue negatively affecting building performance is also recorded. For example, an indoor air quality issue affecting approximately one quarter of the building based on total square footage would be assigned a density of $25 \%$.

The presence and determined severity of each sub-issue, in addition to the measured density or percentage of the total building affected, is used to quantify functionality. Functionality loss is a function of (1) functionality sub-issue type, (2) sub-issue severity, and (3) sub-issue density. This relation is expressed mathematically through the weighted deduct-density model (Shahin 1976):

$$
F I=100-\sum_{i=1}^{I} \sum_{j=1}^{J} a\left(I_{i}, S_{j}, D_{i j}\right) \times F(t, d)
$$

where

$$
\begin{aligned}
\mathrm{FI}= & \text { Functionality Index measure } \\
\mathrm{I}= & \text { number of individual building functionality sub-issues present } \\
\mathrm{J}= & \text { number of individual severity levels present for } \mathrm{i}^{\text {th }} \text { issue. } \\
\mathrm{a}(\mathrm{)}= & \text { functionality deduct value for sub-issue type I, severity } \mathrm{S}, \text { and } \\
& \text { density } \mathrm{D} \text {. } \\
\mathrm{F}(\mathrm{)}= & \text { adjustment factor when multiple sub-issues are present based } \\
& \text { on total summed deduct } \mathrm{t} \text {, and number of sub-issues present } \\
& \text { d. }
\end{aligned}
$$




\subsection{Development of functionality deduct value models}

The FI is developed and designed to simulate the rating obtained by an evaluation from a panel of SMEs. This is accomplished by applying rating scale theory (Hutchison 1963). In effect, the rating scale provides a translation between the functionality loss issues defined and discussed above with a meaningful numerical FI. This is done by soliciting the expertise of a panel of experts in a rigidly controlled rating session. To develop the FI using this method, the following assumptions are invoked:

- Functionality is a measurable attribute.

- Raters are capable of making quantitative judgments about functionality.

- The judgment of each rater can be expressed directly on an interval scale.

- Variability of judgment is a random error.

- Raters are interchangeable.

- Average individual rating values can be used to estimate rating scale values.

During the rating session, each rater was individually presented with a number of different functionality loss scenarios for a hypothetical building. To isolate the concept of condition from development of the functionality metric, the raters were instructed not to consider condition as a reason for functionality degradation. Each functionality sub-issue was presented, along with varying levels of severity and density. The panel was instructed to numerically rate the overall building functionality based on the individual sub-issue, severity, and density presented in each scenario. Each rating was based on the $0-100$ scale described in Table 1, which explicitly describes functionality loss for discrete intervals on the index. This scale provides the guidelines for judging the functionality scenario presented, determining which interval was the best fit, and selecting the actual score within the interval. Adherence to the guidelines ensured consistency and reduced error.

\subsection{Analytical approach}

The functionality rating data obtained from the panel was compiled and analyzed to develop the models for translating the functionality sub-issues into quantitative deduct values. Results were organized based on functionality sub-issue type, severity, and density. Figure 1 shows data plotted for 
the functionality sub-issue of Indoor Air Quality (IAQ), Medium Severity. This issue was rated by the panel at density levels of $1,10,25,50,100 \%$ of building affected, and the associated deduct in functionality is plotted for each rater. After outlier data were removed, the mean deduct value was computed and is represented on Figure 1 by the solid data points. Consequently, the middle trend line represents the density-deduct curve for the issue of medium-severity inadequate IAQ.

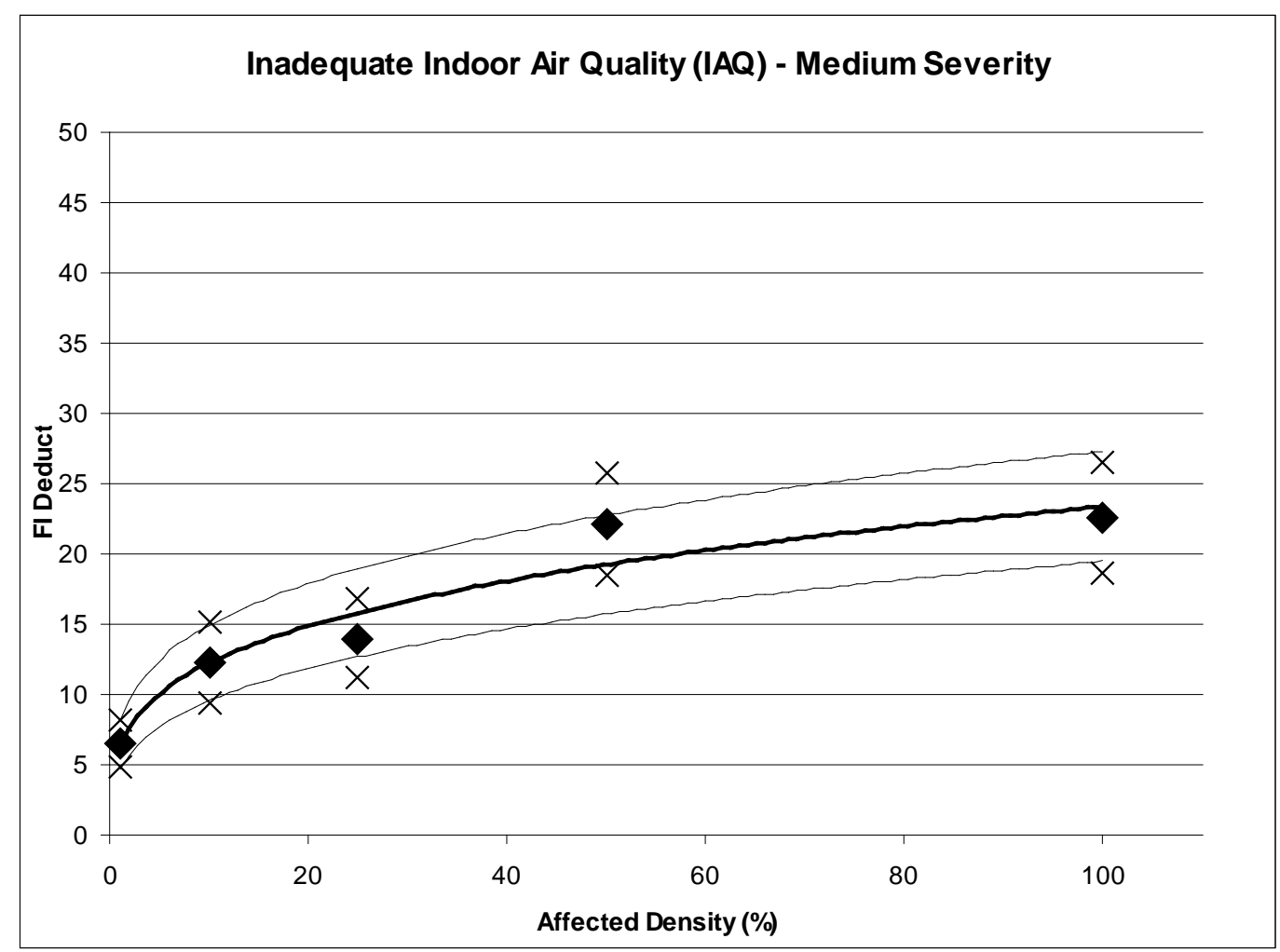

Figure 1. Example deduct rating data for IAQ.

The dotted envelope curves on Figure 1 represent the 95\% confidence interval based on the rating data. The study required a sufficiently large pool of raters to limit the confidence interval to plus or minus 5 points of the mean density/ deduct curve. This constraint allows a consistent and meaningful index to represent the SME panel with statistical rigor.

This data analysis was performed for each of the 126 unique functionality sub-issues affecting a building. Where the collected data indicated a large standard deviation for a sub-issue, that sub-issue was re-rated to correct rater mistakes and narrow the confidence intervals. As a result of this analysis, a mean density/ deduct curve was developed for each functionality sub-issue type. 


\subsection{Adjusting for impact of multiple functionality issues}

When multiple functionality sub-issues exist, the affect on functionality loss is not purely cumulative. If so, it is conceivable several functionality sub-issues could result in a overall building FI less than 0 , which exceeds the bounds of the index metric. In addition, the phenomenon of "psychophysics" results in a reduction in the influence of any given issue when additional issues are present (Weaver 1977). Therefore, a deduct correction factor is applied to the sum of the individual deducts to reflect the nonlinear effect of additional functionality loss issues.

The adjusted deduct factor was derived by providing the SME panel with several scenarios containing multiple functionality loss issues. Depending on the nature of the issue and number of issues present, this overall rating score will result in a functionality deduct value somewhat lower than the sum of the individual issue deduct values as obtained above. By plotting the sum of the individual deduct values on the x-axis of a graph and the direct rating of the combined multiple issues on the y-axis, a correction factor for multiple issues was derived. This correction factor is represented by the slope of each line for the number of issues shown in Figure 2.

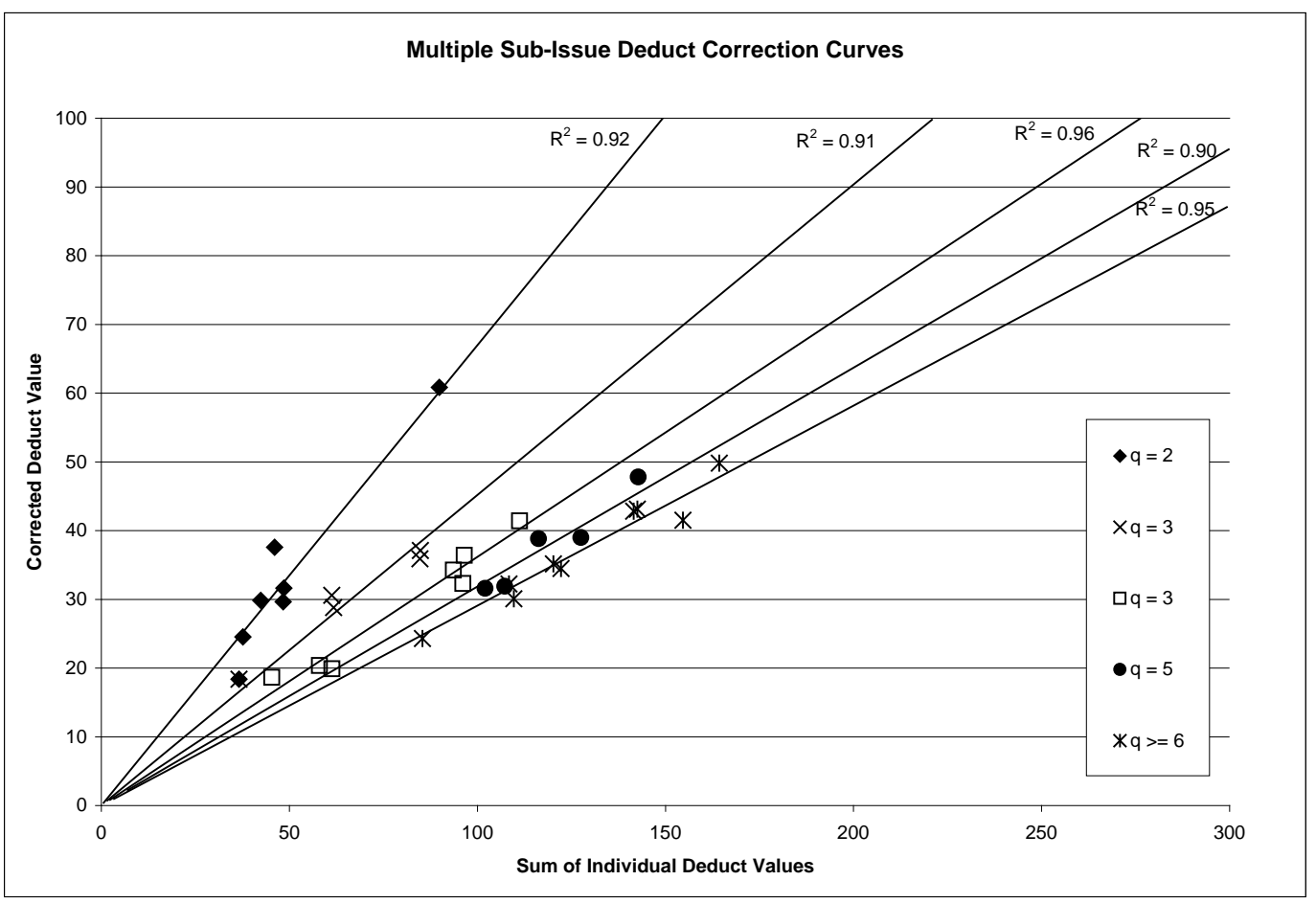

Figure 2. Adjusted deduct factor for multiple issues. 


\subsection{Calculating an FI}

The data models for the functionality density/ deduct curves and the multiple issue adjustment factors have been incorporated into the BUILDER SMS (BUILDER 2005), making BUILDER capable of automated calculation of an FI.

Each sub-issue is essentially presented as a question that the evaluator answers to determine the severity and affect on the building's suitability to support its mission. The answers to these issue questions determine the rating for the functionality issue category and are used to calculate the FI value for the building as a whole. These results are based on the observations of the functionality evaluator, with input from building users and maintenance personnel. The completion of the evaluation allows for a consistent, repeatable, and objective measure of functionality easily used to communicate the suitability of the building to its designated use and mission.

An example calculation for the FI is given below. In this example, two functionality issues have been identified that affect overall performance:

1. Medium Severity, Inadequate Indoor Air Quality. It is determined that an inadequate indoor air quality issue exists in the building, but it is not deemed to be a life-safety issue; therefore, the severity is rated as medium. This indoor air quality affects $50 \%$ of the total building area. Referring to the density/ deduct curve in Figure 1 for this sub-issue, the functionality deduction is 19 points.

2. High Severity, Inadequate Electrical Distribution. It is determined that the facility has inadequate electrical distribution, which significantly impacts mission accomplishment; therefore, the severity is rated as high. This inadequate electrical distribution issue affects $10 \%$ of the overall facility, resulting in a deduction of 31 points.

Using the formula from page 11,

$$
F I=100-\sum_{i=1}^{I} \sum_{j=1}^{J} a\left(I_{i}, S_{j}, D_{i j}\right) \times F(t, d)
$$

the total sum of all deductions from the sub-issues identified is $19+31=$ 50. However, since there are multiple issues, the aggregate index value is 
reduced by the multiple issue correction factor, which is 0.67 for two issues. Thus, the overall building deduction is 34 points, and the building FI is measured to be $100-34=66$, which indicates moderate degradation.

\subsection{Functionality metric for SRM decisions}

The FI is important to building sustainment, restoration, and modernization (SRM) decisions because it is an objective metric. It indicates how suitably the building's inherent characteristics (size, location, configuration, etc.) support its designated purpose, including the safety and overall wellbeing of the building occupants. As planners evaluate different scenarios, the FI produced by the functionality assessment serves as a practical measure of the capabilities and performance of the existing infrastructure portfolio.

The FI also serves the dual role as an execution metric. When the functionality measure for a building falls below the minimum threshold standard defined by policy, as illustrated in Figure 3, modernization requirements are generated. Because the FI is an objectively obtained metric, it provides a defendable way to justify modernization needs.

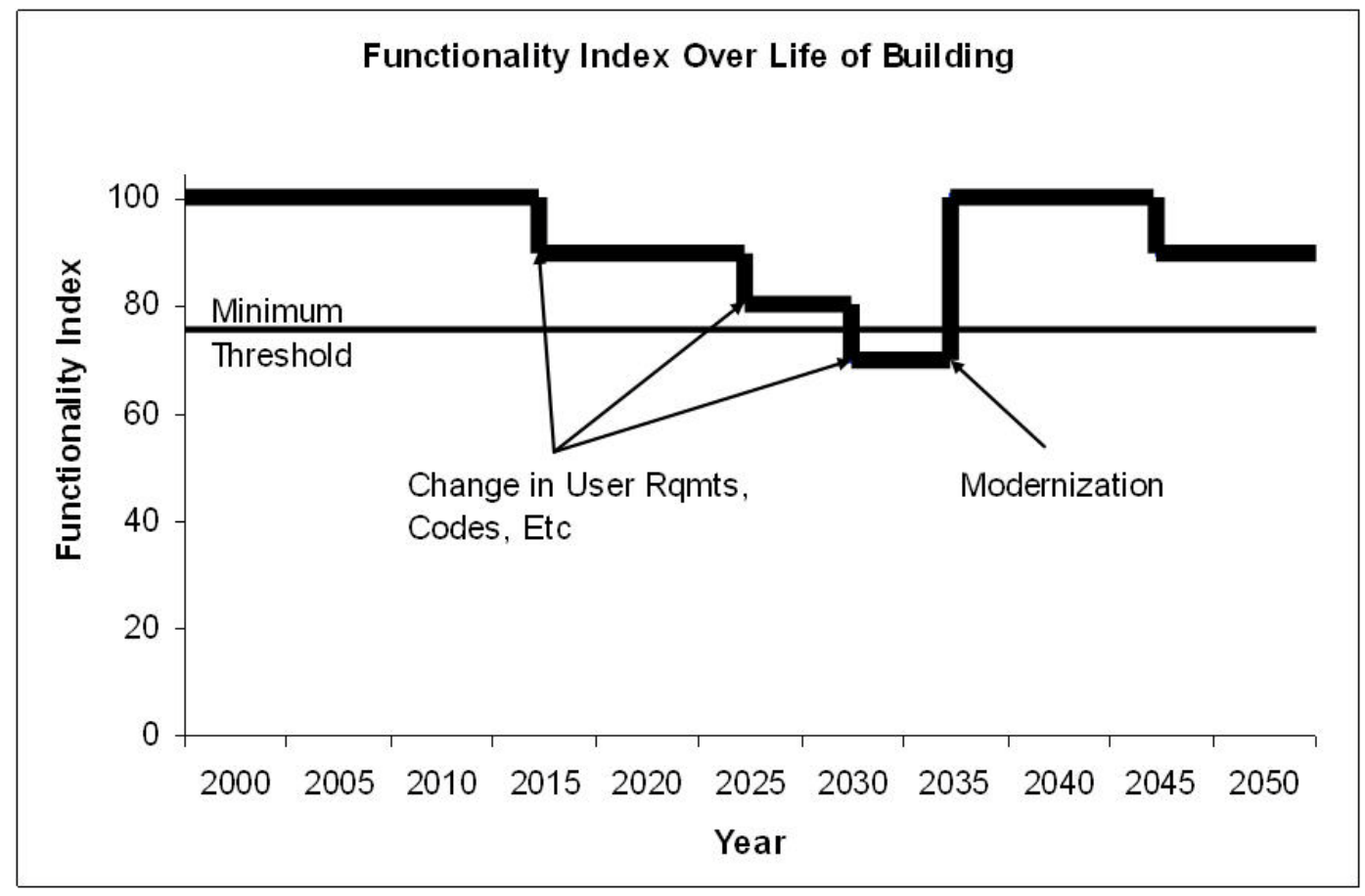

Figure 3. Fl trend over time. 
In addition to determining functionality requirements for a building's current purpose, the approach described here is used to perform functionality assessments to determine future requirements for a proposed purpose. For example, military base closures would require missions (along with the supporting personnel, material, and equipment) being transferred to other bases. The functional characteristics of existing buildings on the receiving bases are assessed to measure their ability to support a new proposed mission. This is the case if a new type of vehicle is scheduled to be stationed at the installation, and infrastructure modernization is required to support this new mission. Multiple what-if scenarios for different building uses and configurations can be assessed, and the results are used in the analysis of modernization requirements.

The building FI, coupled with the CI, provides a means for justifying building rehabilitation - which includes restoration and modernization - versus demolition and new construction. This method supports short- and long-range work plans developed on sound investment strategies, prioritization criteria, and budget constraints.

\subsection{Conclusions}

The functionality assessment process fills a previous gap with information necessary to more completely describe and quantify building performance. It provides a logical, scientific approach to quantifying the effects of changes in user requirements, codes, efficiency, and obsolescence. The resulting FI provides an objective, meaningful, and auditable measure of the infrastructure's capability to provide services to meet mission requirements. Together, the assessment process and index, in conjunction with previously developed condition-based metrics, enhances building SRM decision support by providing transparency to better realize and execute mission-focused facility objectives. 


\section{The BUILDER Functionality Assessment Framework}

BUILDER system implementation is accomplished through the creation of a BUILDER database that consists of building- and component-level inventory information and periodically collected condition survey data. BUILDER analysis and simulation models are then applied to help managers determine candidate building work actions and the estimated cost of work. This chapter identifies the procedures for collecting facility-related data and populating the BUILDER system.

\subsection{Functionality assessment overview}

A new feature included in BUILDER 3.0 is the ability to perform functional assessments to measure a building's functionality state, as described in Chapter 2. Although the functionality assessment is not a detailed engineering assessment, it does satisfy the requirements necessary for routine facility management activities, including long-range budgeting and modernization planning. It also helps to quickly identify problem areas requiring detailed assessments. There are times when detailed engineering assessments may be required to diagnose specific problems.

Functional assessments are structured into a three-tiered, top-down approach to narrow the focus and provide greater assessment detail to the identified issues. This approach saves effort, reduces cost, and directs attention where needed. It also allows the identification and development of modernization requirements to efficiently flow from a broad strategic planning phase to a detailed execution phase. The assessment approach encompasses the three levels shown in Figure 4. 


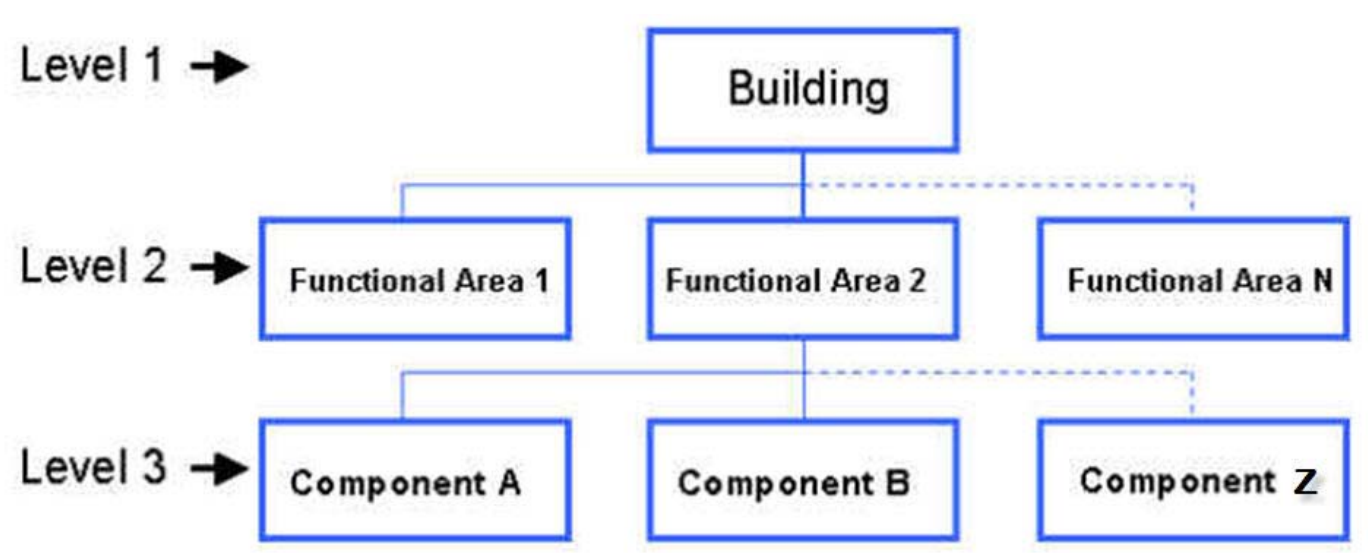

Figure 4. Functionality assessment hierarchy.

In BUILDER 3.0, functionality assessments are performed at the first and second tiers, i.e., the building and functional area levels. Later versions of BUILDER will include the third tier of functionality assessment at the component-section level.

\subsection{Overview of the first tier of assessment}

The first tier of the functionality assessment is a rapid scoping buildinglevel assessment. Using a limited set of questions addressing general functionality issues throughout the building, the first tier provides a quick and accurate way to remove non-problem areas from further assessment, identify problem areas within the building requiring further assessment, and compute the Building Functionality Index (BFI). This level of assessment is performed when an overall indication of building functionality is desired to identify areas requiring further assessment.

\subsection{Overview of the second-tier of assessment}

The second tier of the functionality assessment is a methodical building functional area assessment. This level of assessment produces more accurate results than the first tier, but it usually requires more time. A complete list of functionality questions is used in the second-tier assessment to identify the specific functionality deficiencies in each functional area, compute the Functional Area Functionality Index (FAFI), and refine the $\mathrm{BFI}$. This level of assessment is used when the functionality deficiencies within functional areas need to be identified and results from the first tier need refinement. 


\subsection{Functionality Index computation overview}

All tiers of functionality assessment directly support the computation of the overall FI and the building's functional areas. The BFI and the FAFI both are general obsolescence metrics addressing the issues related to user requirements, technical obsolescence, and regulatory/ code compliance at their respective levels of assessment.

As noted previously, all FI metrics are based on a scale of 0- 100 that correlates with the CI metric used in the BUILDER SMS. BUILDER contains the model algorithms to compute FIs automatically after the functionality assessment data are entered. The algorithms use the data entered about the functionality issues present in the building, the severity of the issues, and the density of the issue to calculate the BFI. The process is illustrated in Figure 5.

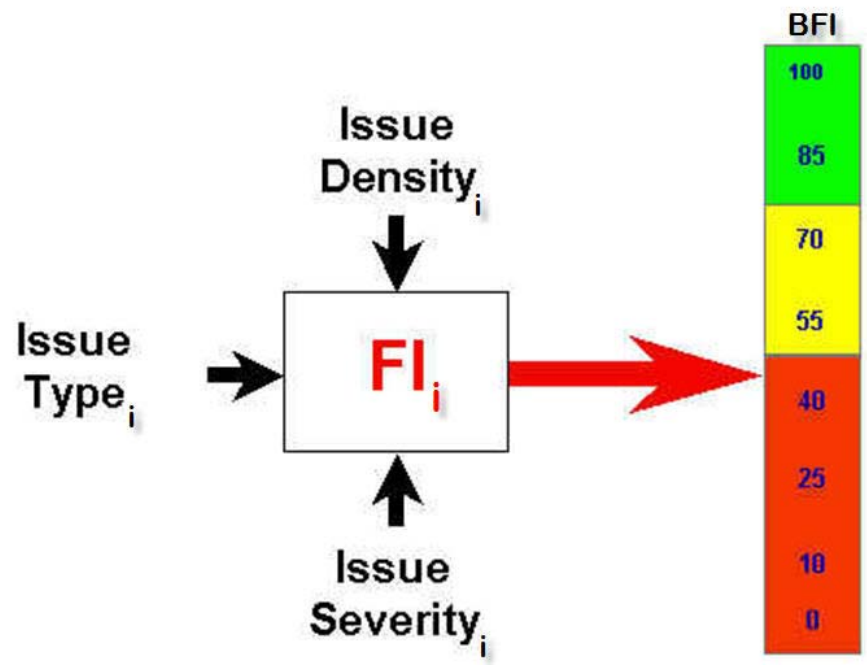

Figure 5. Building Functionality Index (BFI) model.

It is important to note the FI metrics are time-step functions - unlike the continuous functions seen in the CIs - because functionality, unlike condition, does not change gradually. Building or area functionality depends on user needs, degree of technical obsolescence, and compliance with code or regulations. These factors change at discrete points in time, not gradually like the condition of a roofing or electrical system.

\subsection{Performing first-tier functionality assessments}

First tier functionality assessments are associated with the building as a whole. With the addition of the Building Status property in BUILDER 3.0 
it is possible to perform a functionality assessment considering the future (non-current) state of a building. This could be the case if a building is to be leased, transferred, or repurposed at some point in the near future. Assessments of non-current building states are performed in the same manner as current building states. Building-level functionality information is collected in the field using the assessment worksheet provided in Appen$\operatorname{dix} \mathrm{C}$.

In BUILDER, the functionality assessment module is accessed by clicking on the Functionality Assessment button on the main menu bar (Figure 6).

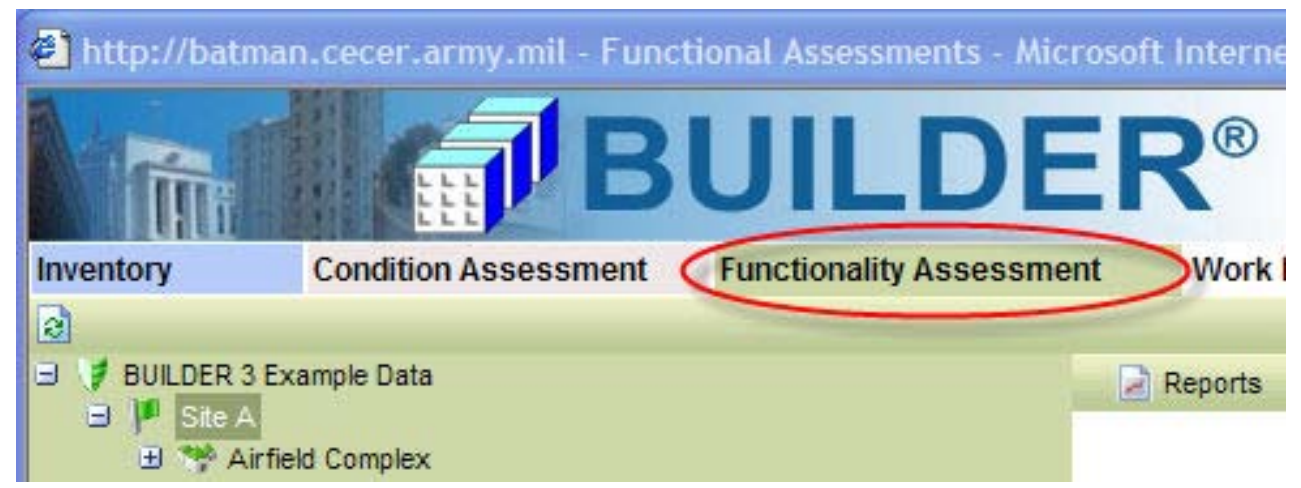

Figure 6. Access to the BUILDER functionality assessment module.

The functionality assessment navigation window appears. Navigate the tree to the building for which the functionality assessment is to be performed. The window shown in Figure 7 appears.

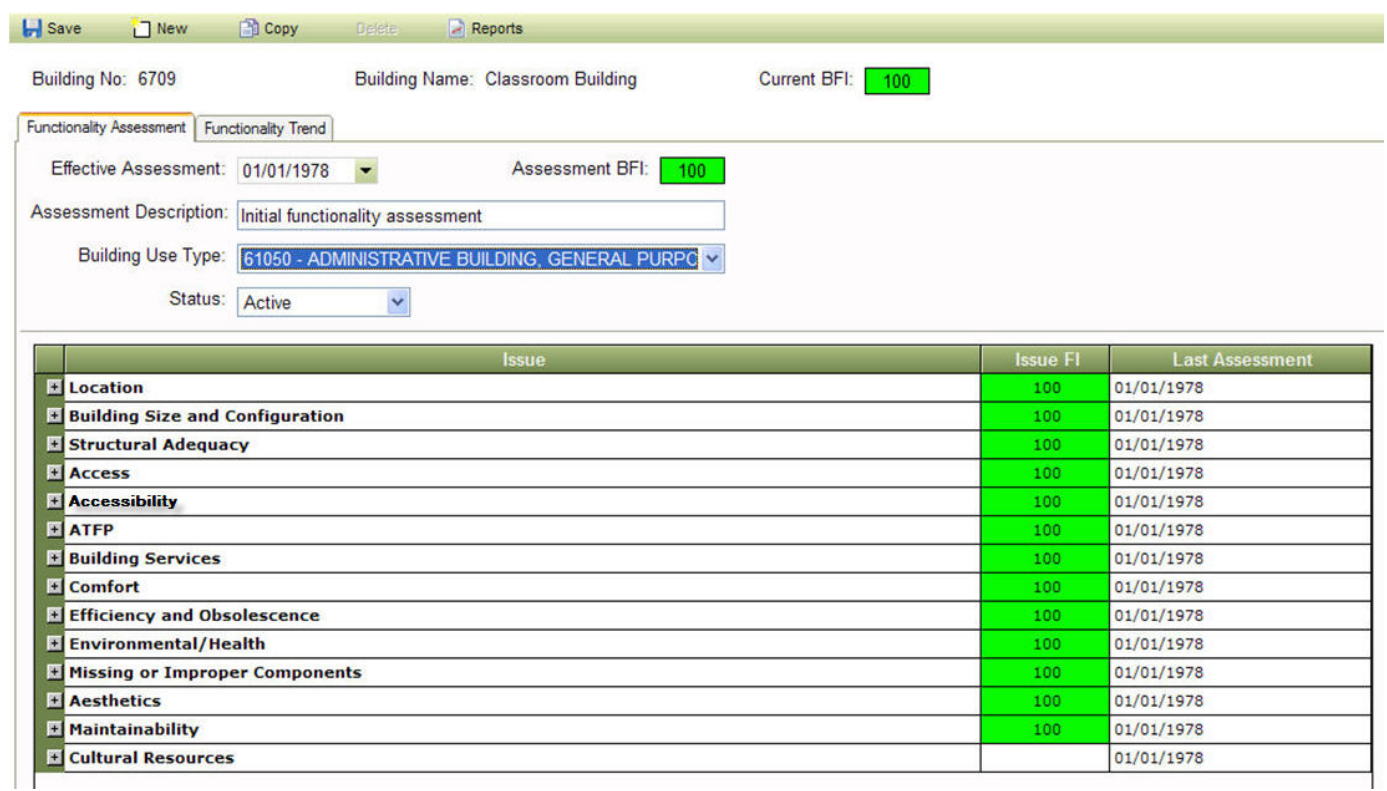

Figure 7. BUILDER functionality assessment screen. 


\subsection{Functionality assessment data}

After a building is selected, general data about the building are shown at the top of the screen. These data include the building number, building name, and the current BFI. Below this is additional information associated with functional assessments of the building:

- Effective Assessment (Required). Select the date of the functionality assessment you wish to see data for from the dropdown list. All functionality assessments previously recorded are accessible from this list. If you have created a new functionality assessment, the current date is shown in this field.

- Assessment BFI (Read-Only). Displays the BFI computed based on the data recorded for the assessment currently selected.

- Assessment Description (Optional). Enter a brief description on the functionality assessment.

- Building Use Type (Required). Select the building use type from the dropdown list most closely matching the building. If you are a Department of Defense activity, BUILDER displays familiar category codes for your service. This field is helpful when a building is being assessed against many use types to determine its optimal use type.

- Status (Required). Select the status of the current assessment from the dropdown list. The status options available for a functionality assessment in BUILDER 3.0 are:

o Active - This is the functionality assessment currently applied to the building and is used to compute the current BFI.

o Past - This is a past functionality assessment. These assessment data are not used when computing the current BFI.

o To Take Effect - This sets the current functional assessment to a future year when user requirements, codes, or obsolescence are expected to change and affect the functionality of the building. These assessments are particularly useful for running long-range work planning scenarios.

- Effective Year of Status. Enter the year the status of the assessment becomes active, or effective in the building. This field will only appear if the status is set to "To Take Effect."

The actual assessment data are displayed and recorded in the grid in the lower portion of the screen and includes: 
- Issue (Read-Only). Displays the 14 first tier functionality issues included in BUILDER 3.0. Expand the issues to show its sub-issues by using the "+" button next to the issue. If the sub-issues are expanded, they can be collapsed by clicking the "-" button next to the issue.

- Rating (Read-Only). Displays the FI rating for the issue computed from the ratings of its sub-issues.

- Last Assessment (Read-Only). Displays the date of the last functionality assessment for the issue.

- Sub-Issue (Read-Only). If the issues have been expanded, its sub-issues are shown in this column on the grid.

- Sub-Issue Rating. Enter the applicable rating data for the functionality sub-issues in the building. The rating for each sub-issue consists of a severity color rating along with a density range for some sub-issues. The hyperlinked text for each sub-issue provides a link to the definition and rating guidelines of the sub-issue.

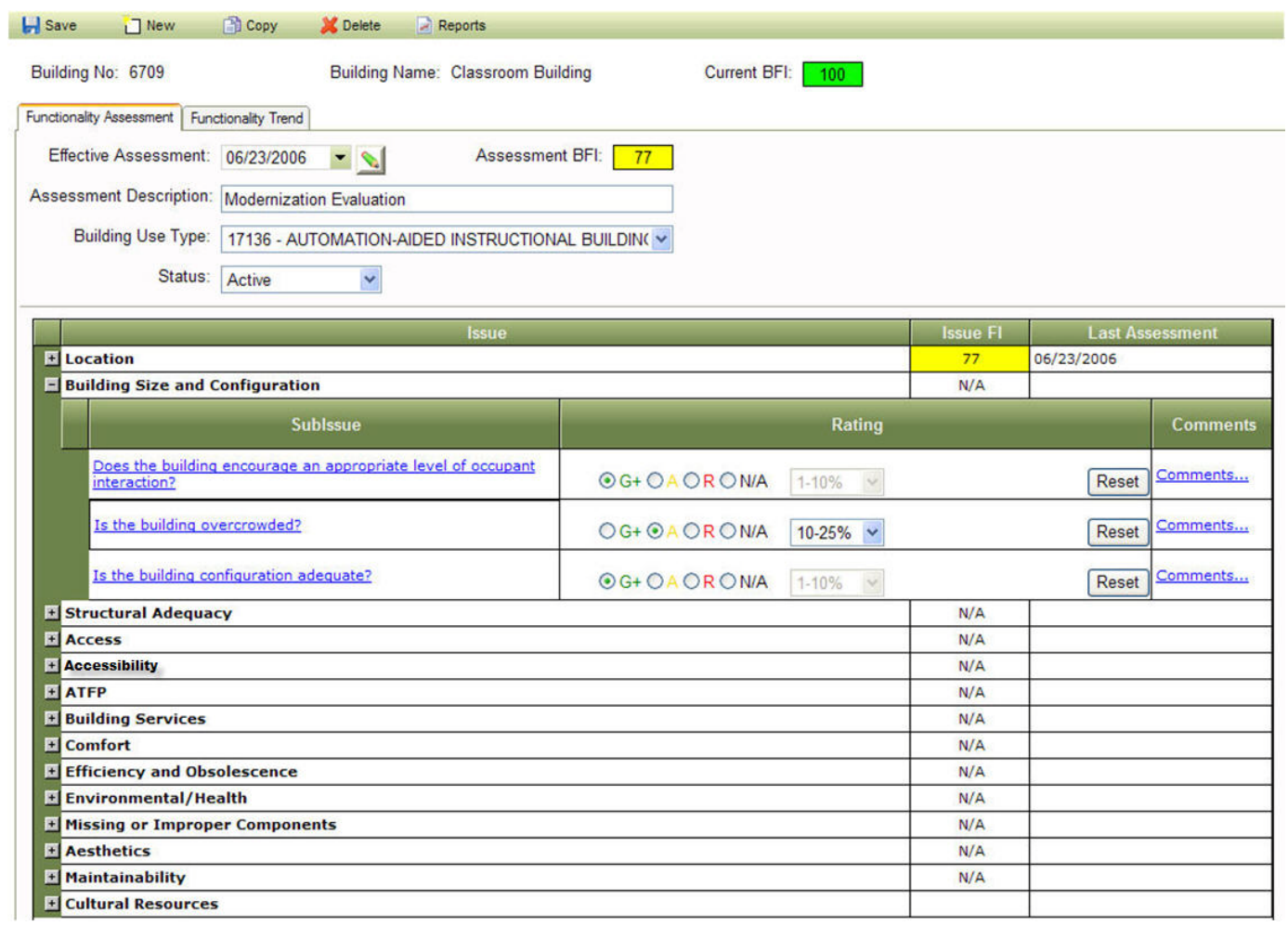

Figure 8. Functionality sub-issue rating screen.

\subsection{Rating sub-issues with wizards}

A wizard is required to help guide the rating for some sub-issues. To launch the wizard, click the WIZARD link included in the sub-issue row. The wizard for the sub-issue will appear in a new window, in which you 
can complete the rating. Note you are not able to directly enter the severity rating or density from the sub-issue grid without going through the wizard.

\subsection{Sub-issue comments}

Additionally, comments shall be added as appropriate for each sub-issue by clicking the COMMENTS button in the sub-issue row. The comments window will appear in a new window. Enter any comments about the rating of the sub-issue and click CLOSE to close the window and save the changes. 


\section{Linkage of Army Standard Design Criteria to the FI Assessment Framework}

Inappropriate building layout, poorly chosen materials or equipment, code violations, etc., interfere with a building's capability to support its mission requirements. The Army's existing process to assess the condition, performance, and readiness of facilities is the Installation Status Report for Infrastructure (ISR-I). While the ISR-I assessment attempts to identify facility requirements affecting readiness and mission, there is no formal process for incorporating current Army Standards and Standard Designs into the assessment procedure. By incorporating design standards into the ISR-I assessment, Army installations can evaluate their existing buildings and collect data based on the latest facility design requirements. Such an approach allows consistent comparison against the latest Army Standards baseline. In addition, the information collected from the ISR-I feeds into the BUILDER functionality assessment framework to help calculate an FI.

As previously noted, the ACISM is responsible for developing and publishing Army Facility Standards, and the USACE COSs are responsible for implementing them in Army Standard Designs. These documents specify requirements and features for a newly constructed facility, but a vast majority of existing Army facilities were not built to comply with them. Nevertheless, it is necessary to evaluate the performance of existing facilities against the current facility requirements in order to understand how these facilities can support the Army's current and future projected technology and weapons systems.

This project categorized the standard design criteria for four Tier 1 mission-critical facility types: the Tactical Equipment Maintenance Facility (TEMF), the Company Operations Facility (COF), the Battalion Headquarters Facility, and the Brigade Headquarters Facility. That information was then linked to BUILDER functionality sub-issues and ISR-I mission criteria, and a data element map was created. Several appendices to this report document guidance for incorporating information and assessment criteria and how that information is incorporated into Army facility management systems. Army standard design criteria categories for Tier 1 facilities are presented in detail in appendices D- G. An example breakdown and categorization of the design standard criteria for the TEMF is shown in Figure 


\section{The figure shows a small subset of standard design criteria organized by functional space, building components affected, and functionality issues affected, along with the actual requirement criteria.}

\begin{tabular}{|c|c|c|c|}
\hline \multicolumn{4}{|c|}{ Brigade Headquarters - BOC (if required) determined by TOE } \\
\hline Components Affected & issue & Requirement & Reference Code \\
\hline Floor & Configuration & Raised access flooring or On ground flooring & \\
\hline \multicolumn{4}{|c|}{ Brigade Headquarters - NOC } \\
\hline Components Affected & Issue & Requirement & Reference Code \\
\hline Floor & Configuration & Raised access flooring or On ground flooring & \\
\hline \multicolumn{4}{|c|}{ Brigade Headquarters - SCIF } \\
\hline Components Affected & issue & Requirement & Reference Code \\
\hline Floor & Configuration & Raised access flooring or On ground flooring & \\
\hline \multirow[t]{4}{*}{ Intrusion Detection } & Security & Access control and intrusion detection for monitoring and controlling access & \\
\hline & Access & Ground level access to the TSOA & \\
\hline & Security & Protection from surreptitious entry & \\
\hline & Security & Protection from forced entry & \\
\hline \multirow[t]{4}{*}{ Insulation } & Sound Proof & Protection form Classified discussions being heard outside & \\
\hline & Security & Protection from Implantation of technical surveillance devices & \\
\hline & Security & Protection from visual observation & \\
\hline & Security & Protection from stand-off technical attack & \\
\hline \multicolumn{4}{|c|}{ Brigade Headquarters - Tactical SCIF Operations Areas (TSOA) } \\
\hline \multirow[t]{6}{*}{ Components Affected } & issue & Requirement & Reference Code \\
\hline & & Ground floor location & \\
\hline & Location & Adjacent to the permanent SCIF & \\
\hline & & Vehicle shelters IAW DCID $6 / 9$ or ICD 704 & \\
\hline & & Telecom routed through DIAVAC-22 approved PDS from Perm SCIF to TSOA & \\
\hline & & Fenced with CCTV monitored $24 / 7$, locks, access control, intrusion detection & \\
\hline Parking & Availability & Parking area for tow HMMW vehicles with trailer provided adjacent to SCIF. & \\
\hline Fencing & Security & $\begin{array}{l}\text { A perimeter fence consisting of a } 6 \text {-foot high chain link fabric topped by a single outrigger } \\
\text { with thre e-strand barbed wire designed in accordance with STD } 872-90-03 \text {, FE-6. }\end{array}$ & STD 872-90-03, FE-6 \\
\hline Pavement & Size & $\begin{array}{l}\text { Provide } 30 \text {-fo ot wide by } 40 \text { foot long rigid concrete pavement designed to support HMMWN } \\
\text { vehicles with trailers }\end{array}$ & \\
\hline Landscape & Spacing & $\begin{array}{l}\text { A } 10 \text {-foot wide zone clear of trees and shrubs is required on each side of the fence. Should } \\
\text { require minimal maintenance, and the area } 5 \text { feet each side of the fence should have } \\
\text { grayel. }\end{array}$ & \\
\hline Transformers & Location & Not above ground in this area & \\
\hline Generat ors & Location & Not above ground in this area & \\
\hline Mechanic al Equipment & Location & Not above ground in this area & \\
\hline
\end{tabular}

Figure 9. Example Army Standard Design Criteria.

This information is structured to fit within the component and subcomponent fields in the ISR-I criteria. It is also organized to fit within the BUILDER component inventory structure and functionality sub-issue framework. 


\section{Summary and Recommendations}

\subsection{Summary}

The integration of the BUILDER SMS FI assessment framework into existing Army systems and processes offers implementation opportunities based on best practices and least costs. The Army ISR-I process is already in place to assess facilities, and it includes some mission-related functional aspects. (Army ISR-I criteria related to several Tier 1 facility types are listed in detail in appendices K- N.)

The research team concludes that integration of the Army Standards and Standard Designs with existing Army ISR-I mission performance criteria will provide more accurate data and better correlate with the latest Army design standards, which are based on current requirements for new stateof-the-art facilities. The leveraging of effective systems that are already in place will contain costs to only resources dedicated to incremental additional data collection. This integrated approach will make it possible to compare the performance of existing buildings with a common baseline. To accomplish this, Army ISR-I criteria would require some modification (i.e., standardization) in order to incorporate the latest Army Standards and Standard Design requirements.

Once ISR-I facility criteria are standardized, they would be linked to the BUILDER SMS functionality assessment framework in such a way that data collected through the ISR-I would be uploaded automatically to BUILDER. This automated linkage would produce a Building Functionality Index (BFI) value for each facility based on ISR-I mission criteria ratings. Using this approach, BUILDER data updates would be accomplished during the routine ISR-I inspection process. Figure 10 charts an overview of the integration process.

A training program is needed to support accurate and consistent collection of facility functionality information through the ISR-I criteria rating process. Annual ISR-I training is already provided for Army users, so any modifications to the mission-related facility criteria rating guidelines, system data entry, or reports generation will need to be included as part of this training process. 


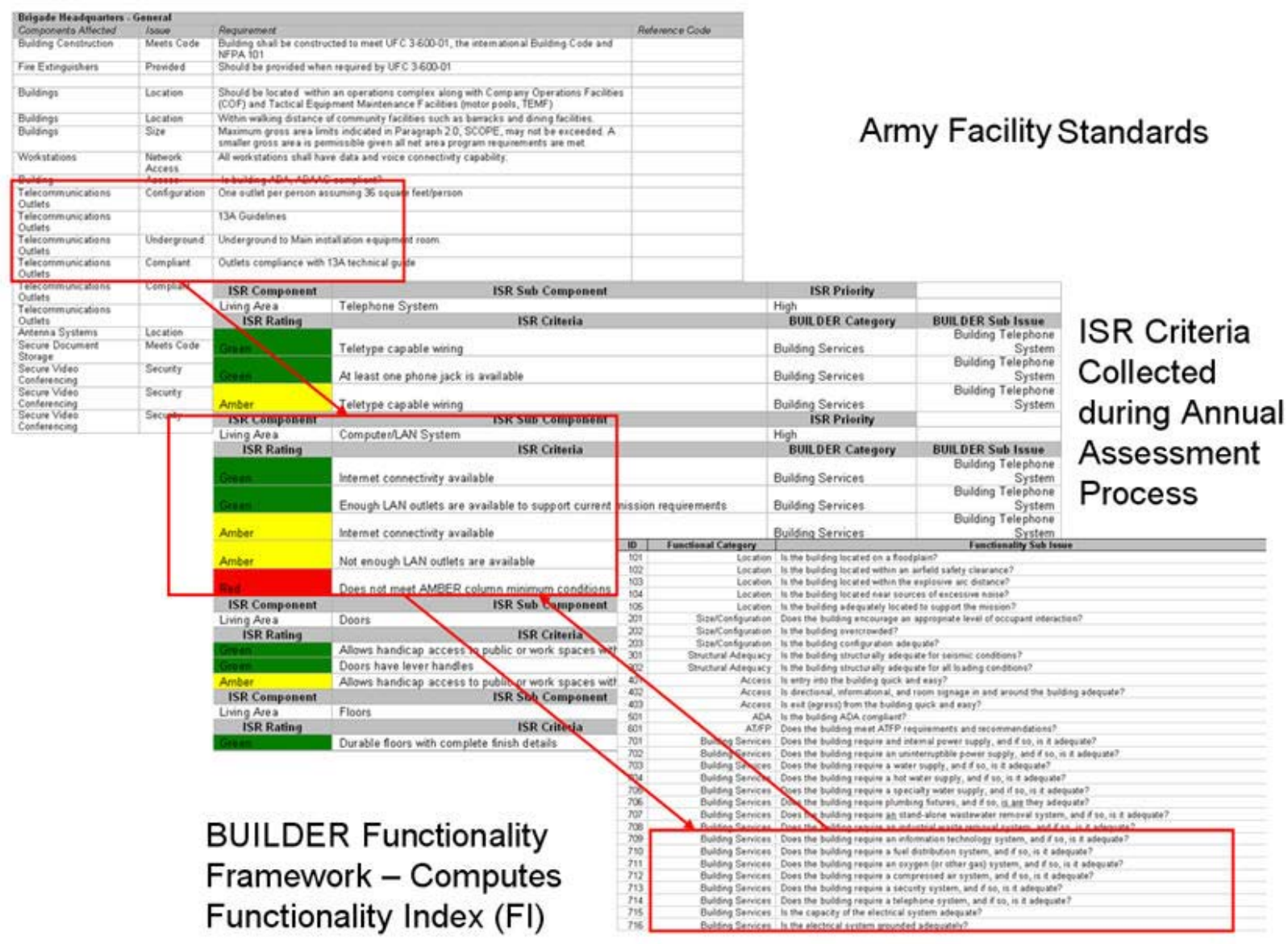

Figure 10. Integration process chart.

\subsection{Recommendations}

\subsubsection{Enterprise IT platform}

To effectively employ the BUILDER SMS for Army facilities, integration with other Army systems is required to provide a seamless management and reporting process (Figure 11). The project team recommends that detailed facility functionality criteria be stored in the BUILDER SMS for analysis of facility metrics used in SRM planning. BUILDER's open data architecture permits free communication with other electronic Army facility management systems and data repositories. Communication links between those systems and BUILDER can be created using web services and Extended Markup Language (XML) exchange features. 
Army Corporate Systems

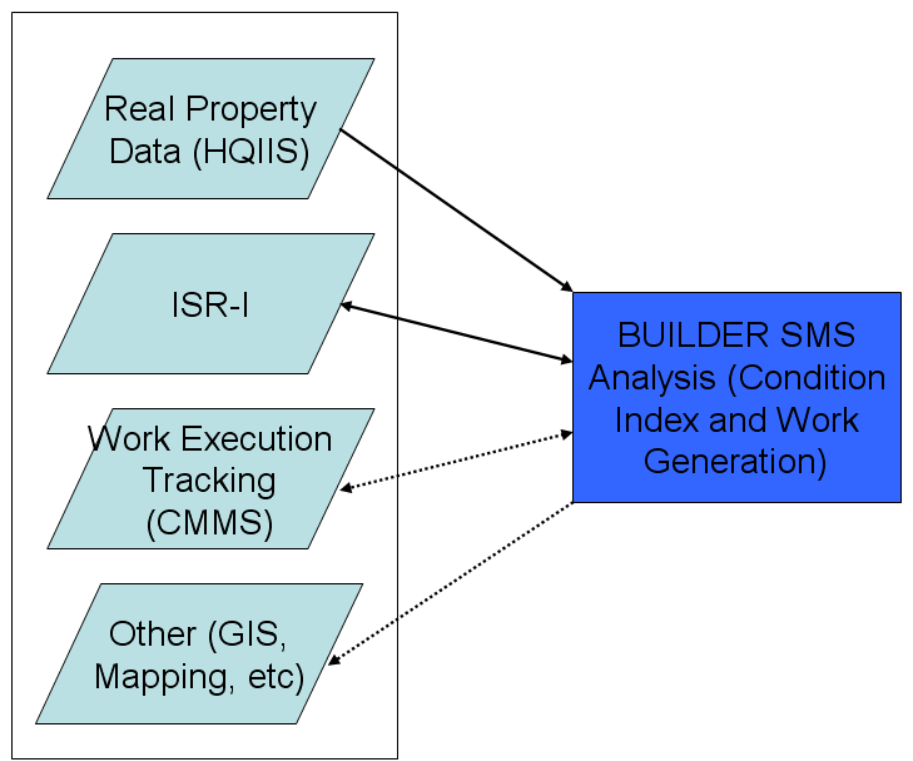

Figure 11. System integration.

\subsubsection{Linkage to ISR}

The ISR-I is the Army process that installation personnel use to report the condition and readiness of facility assets. Building tenants are primarily responsible for providing a condition/ readiness rating based on standardized guidelines that consider several aspects of the facility. This process produces a green, amber, or red rating for each the building, which eventually gets rolled up by building Category Code. While the ISR-I assessment process attempts to identify facility requirements affecting readiness and mission, there is no formal process to incorporate current Army Standards and Standard Designs into the assessment. Development of a formal linkage between the ISR-I, Army Standards, and Standard Designs is recommended to enable Army installations to evaluate their existing buildings and to collect data based on the latest facility design. The linkage will facilitate consistent comparison of ISR-I results with the latest Army standards baseline. In addition, information collected from the ISR-I can feed into the BUILDER functionality assessment framework to calculate an FI value.

\subsubsection{Integration with the General Fund Enterprise Business System (GFEBS)}

GFEBS is an Army system being deployed to replace several major financial systems, and is used extensively by installation DPWs. Under GFEBS 
architecture, BUILDER information would directly support the management of Property, Plant, and Equipment (PP\&E) Inventory. Potential benefits include the tracking of asset value changes; depreciation, amortization, and depletion of assets; and maintenance, repair, and replacement of assets. To most effectively accomplish these tasks, Army personnel need an integrated approach that allows them to seamlessly develop annual work plans in BUILDER while utilizing GFEBS to actively manage the execution of these work projects. Because these systems will share real property and work information, an integration plan is required. To comprehensively identify the information and data flows required, a system analyst will need to evaluate the policy and guidance documents to align how assets are stored in each system, what external interfaces are available for exchanging data between systems, and the format for the messages passed between these systems.

\subsubsection{Linking with Army Mapper}

Army Mapper provides enterprise-wide GIS support. It is a geographic data repository for all installation infrastructures, and is used for master planning purposes. BUILDER open architecture allows for linkage of BUILDER data tables to this Army corporate GIS system for integration. The research team recommends this linkage, which would allow for building information, displayed via building footprint shapefiles, to be overlaid with other infrastructure domains, such as pavements, railroads, airfields, and other utilities. The integration of BUILDER and Army Mapper would provide a comprehensive view of the installation in native GIS architecture format. 


\section{References}

ASTM D 5340-93, 1993 Annual Book of ASTM Standards (ASTM, Philadelphia, PA 1993), pp 630-636.

BUILDER (2005). BUILDER Engineered Management System, http:// dwww.cecer.army.mil / td/ tips/ product/ details.cfm?ID=64\&TOP=1

GAO (2003). Changes in Funding Priorities and Strategic Planning Needed to Improve Condition of Military Facilities, www.gao.gov.

Hutchison, B.G (1963), Principles of Subjective Rating Scale Construction, Highway Research Record No. 46 (Highway Research Board of the National Academy of Sciences, National Research Council), pp 60-70.

Shahin, M.Y., M.I. Darter, and S.D. Kohn (1976). Development of a Pavement Maintenance Management System, Volume 1. Airfield Condition Rating, AFCECTR-76-27, Air Force Civil Engineering Center.

Uzarski, D.R. and L.A. Burley (1997). Assessing Building Condition by the Use of Condition Indexes, Proceedings of the ASCE Specialty Conference Infrastructure Condition Assessment: Art, Science, Practice, pp.365-374.

Weaver, R.J ., and R.O. Clark (1977), Psychophysical Scaling of Pavement Serviceability, Soils Engineering Manual SEM-9 (New York State Department of Transportation). 


\section{Acronyms and Abbreviations}

ACSIM - Assistant Chief of Staff for Installation Management

BCI - Building Condition Index

BFI - Building Functionality Index

BPI - Building Performance Index

CERL - Construction Engineering Research Laboratory

CI - Condition Index

COBIE - Construction Operations Building Information Exchange

DPW - Directorate of Public Works

ERDC - Engineer Research and Development Center

FCI - Facility Condition Index

FI - Functionality Index

GFEBS - General Fund Enterprise Business System

GIS - Geographic Information System

HQ - Headquarters

HQIIS - Headquarters Installation Information System

IFS - Integrated Facilities System

IMCOM - Installation Management Command

ISR-I - Installation Status Report 
IT - Information Technology

MDI - Mission Dependency Index

M\&R - Maintenance and Repair

O\&M - Operations and Maintenance

OSD - Office Secretary of Defense

PP\&E - Property, Plant, and Equipment

PRV - Plant Replacement Value

RPUID - Real Property Unique ID

ROI - Return on Investment

SMS - Sustainment Management System

SRM - Sustainment, Restoration, Modernization 


\section{Appendix A: BUILDER SMS Building Level Functionality Issues}

\begin{tabular}{|c|c|c|}
\hline ID & Functional Category & Functionality Sub Issue \\
\hline 101 & Location & Is the building located on a floodplain? \\
\hline 102 & Location & Is the building located within an airfield safety clearance? \\
\hline 103 & Location & Is the building located within the explosive arc distance? \\
\hline 104 & Location & Is the building located near sources of excessive noise? \\
\hline 105 & Location & Is the building adequately located to support the mission? \\
\hline 201 & Size/Configuration & Does the building encourage an appropriate level of occupant interaction? \\
\hline 202 & Size/Configuration & Is the building overcrowded? \\
\hline 203 & Size/Configuration & Is the building configuration adequate? \\
\hline 301 & Structural Adequacy & Is the building structurally adequate for seismic conditions? \\
\hline 302 & Structural Adequacy & Is the building structurally adequate for all loading conditions? \\
\hline 401 & Access & Is entry into the building quick and easy? \\
\hline 402 & Access & $\begin{array}{l}\text { Is directional, informational, and room signage in and around the building } \\
\text { adequate? }\end{array}$ \\
\hline 403 & Access & Is exit (egress) from the building quick and easy? \\
\hline 501 & Accessibility & Is the building ABA compliant? \\
\hline 601 & AT/FP & Does the building meet ATFP requirements and recommendations? \\
\hline 701 & Building Services & $\begin{array}{l}\text { Does the building require and internal power supply, and if so, is it } \\
\text { adequate? }\end{array}$ \\
\hline 702 & Building Services & $\begin{array}{l}\text { Does the building require an uninterruptible power supply, and if so, is it } \\
\text { adequate? }\end{array}$ \\
\hline 703 & Building Services & Does the building require a water supply, and if so, is it adequate? \\
\hline 704 & Building Services & Does the building require a hot water supply, and if so, is it adequate? \\
\hline 705 & Building Services & Does the building require a specialty water supply, and if so, is it adequate? \\
\hline 706 & Building Services & $\begin{array}{l}\text { Does the building require plumbing fixtures, and if so, is are they } \\
\text { adequate? }\end{array}$ \\
\hline 707 & Building Services & $\begin{array}{l}\text { Does the building require an stand-alone wastewater removal system, and } \\
\text { if so, is it adequate? }\end{array}$ \\
\hline 708 & Building Services & $\begin{array}{l}\text { Does the building require an industrial waste removal system, and if so, is } \\
\text { it adequate? }\end{array}$ \\
\hline 709 & Building Services & $\begin{array}{l}\text { Does the building require an information technology system, and if so, is it } \\
\text { adequate? }\end{array}$ \\
\hline 710 & Building Services & $\begin{array}{l}\text { Does the building require a fuel distribution system, and if so, is it } \\
\text { adequate? }\end{array}$ \\
\hline 711 & Building Services & $\begin{array}{l}\text { Does the building require an oxygen (or other gas) system, and if so, is it } \\
\text { adequate? }\end{array}$ \\
\hline 712 & Building Services & $\begin{array}{l}\text { Does the building require a compressed air system, and if so, is it } \\
\text { adequate? }\end{array}$ \\
\hline 713 & Building Services & Does the building require a security system, and if so, is it adequate? \\
\hline
\end{tabular}




\begin{tabular}{|c|c|c|}
\hline ID & Functional Category & Functionality Sub Issue \\
\hline 714 & Building Services & Does the building require a telephone system, and if so, is it adequate? \\
\hline 715 & Building Services & Is the capacity of the electrical system adequate? \\
\hline 716 & Building Services & Is the electrical system grounded adequately? \\
\hline 717 & Building Services & Are the electrical outlets adequate? \\
\hline 801 & Comfort & Does the building have the HVAC capacity to be heated adequately? \\
\hline 802 & Comfort & Does the building have the HVAC capacity to be cooled adequately? \\
\hline 803 & Comfort & Does the building have the HVAC capacity to be dehumidified adequately? \\
\hline 804 & Comfort & Does the building have the HVAC capacity to be humidified adequately? \\
\hline 805 & Comfort & Does the building have the HVAC capacity to be ventilated adequately? \\
\hline 806 & Comfort & Are the HVAC controls adequate? \\
\hline 807 & Comfort & Is there disruptive noise in the building? \\
\hline 808 & Comfort & Is the building adequately lit? \\
\hline 809 & Comfort & Are the lighting controls adequate? \\
\hline 901 & Efficiency/Obsolescence & Is the equipment energy efficient? \\
\hline 902 & Efficiency/Obsolescence & Is the building adequately zoned for HVAC? \\
\hline 903 & Efficiency/Obsolescence & Are efficient lighting controls in use and adequate where applicable? \\
\hline 904 & Efficiency/Obsolescence & Are efficient light fixtures in use and adequate where applicable? \\
\hline 905 & Efficiency/Obsolescence & $\begin{array}{l}\text { Are water conservation mechanisms in use and adequate where } \\
\text { applicable? }\end{array}$ \\
\hline 906 & Efficiency/Obsolescence & $\begin{array}{l}\text { Are energy efficient windows and doors in use and adequate where } \\
\text { applicable? }\end{array}$ \\
\hline 907 & Efficiency/Obsolescence & Does the insulation meet building requirements? \\
\hline 1001 & Environment/Life Safety & Is the lightning protection adequate? \\
\hline 1002 & Environment/Life Safety & Is asbestos present in the building? \\
\hline 1003 & Environment/Life Safety & Is the indoor air quality of the building adequate? \\
\hline 1004 & Environment/Life Safety & Is lead paint present in the building? \\
\hline 1005 & Environment/Life Safety & Is lead present in the building's water? \\
\hline 1006 & Environment/Life Safety & Are PCBs present in the building? \\
\hline 1007 & Environment/Life Safety & Is radon present in the building? \\
\hline 1008 & Environment/Life Safety & Is the fire and smoke detection/warning system adequate? \\
\hline 1009 & Environment/Life Safety & Are flammable and combustible materials adequately stored? \\
\hline 1010 & Environment/Life Safety & Is the fire suppression equipment adequate? \\
\hline 1101 & Missing/Improper Comps & Are all the necessary components present? \\
\hline 1102 & Missing/Improper Comps & Is the correct type of each component present? \\
\hline 1201 & Aesthetics & $\begin{array}{l}\text { Does the quality and appearance of the exterior create a positive } \\
\text { impression on the public and building occupants? }\end{array}$ \\
\hline 1202 & Aesthetics & $\begin{array}{l}\text { Does the quality and appearance of the interior create a positive } \\
\text { impression on the public and building occupants? }\end{array}$ \\
\hline 1301 & Maintainability & $\begin{array}{l}\text { Does the design of or placement of equipment allow for easy } \\
\text { maintenance? }\end{array}$ \\
\hline 1401 & Cultural Resources & Does this building have any cultural resources (historical significance)? \\
\hline
\end{tabular}




\section{Appendix B: BUILDER Functionality Index Interval Definitions}

\begin{tabular}{|c|c|c|}
\hline $\mathrm{FI}$ & Rating Definition & Modernization Needs \\
\hline 100 & $\begin{array}{l}\text { No functionality problems exist in building. All occupant/user } \\
\text { requirements are met, no component-sections are obsolete, and the } \\
\text { building is in full compliance with all codes and regulations. }\end{array}$ & None \\
\hline $86-99$ & $\begin{array}{l}\text { One or more, up to a very few, non-critical or critical component- } \\
\text { sections suffer from varying degrees of functionality loss; and/or Up } \\
\text { to a small number of component-section inventory items suffer from } \\
\text { varying degrees of functionality loss; and/or One or }\end{array}$ & \multirow{2}{*}{$\begin{array}{l}\text { Up to total modernization desired } \\
\text { or required for up to a few } \\
\text { component-sections or few } \\
\text { inventory items (i.e. items that } \\
\text { collectively make up a component- } \\
\text { section) for given component- } \\
\text { sections; or } \\
\text { Minor modernization desired or } \\
\text { required to certain building }\end{array}$} \\
\hline $71-85$ & $\begin{array}{l}\text { More than a very few, but not many, non-critical or critical component- } \\
\text { sections suffer from varying degrees of functionality loss; or } \\
\text { combinations of a few non-critical and critical component-sections } \\
\text { suffer from varying degrees of functionality loss, and }\end{array}$ & \\
\hline $56-70$ & $\begin{array}{l}\text { Many, non-critical and critical component-sections suffer from varying } \\
\text { degrees of functionality loss; and/or Large numbers of component- } \\
\text { section inventory items are experiencing varying degrees of } \\
\text { functionality loss, and/or One or more critical building fu }\end{array}$ & \multirow{3}{*}{$\begin{array}{l}\text { Up to total modernization required } \\
\text { to significant numbers of } \\
\text { component-sections or the } \\
\text { inventory items for given } \\
\text { component-sections; or } \\
\text { Significant modernization required } \\
\text { to one or more building functional } \\
\text { areas; or major modernization } \\
\text { required to small b }\end{array}$} \\
\hline $41-55$ & $\begin{array}{l}\text { One or more critical building functional areas are experiencing } \\
\text { significant functional loss and other building functional areas may be } \\
\text { experiencing functional loss to a significant or lesser degree; and/or } \\
\text { Building, as a whole, is functionally impaired to }\end{array}$ & \\
\hline $26-40$ & $\begin{array}{l}\text { One or more critical building functional areas are experiencing } \\
\text { extensive functional loss and other building functional areas may be } \\
\text { experiencing functional loss to an extensive or lesser degree; and/or } \\
\text { Building, as a whole, is functionally impaired to an }\end{array}$ & \\
\hline $11-25$ & $\begin{array}{l}\text { The majority of building functional areas is experiencing a functional } \\
\text { loss to some degree with one or more being severe (total or nearly } \\
\text { so); or } \\
\text { Building, as a whole, is barely able to serve its intended or proposed } \\
\text { use. }\end{array}$ & \multirow[t]{2}{*}{$\begin{array}{l}\text { Major modernization required to } \\
\text { large portions of or the entire } \\
\text { building; or } \\
\text { Building relocation required. }\end{array}$} \\
\hline $0-10$ & Building is totally unable to serve its intended or proposed use. & \\
\hline
\end{tabular}




\section{Appendix C: Example Building Functionality Assessment Sheet}

\begin{tabular}{|c|c|c|c|c|}
\hline \multicolumn{5}{|l|}{ Functionality Assessment Details } \\
\hline \multicolumn{5}{|l|}{ General Information } \\
\hline \multicolumn{5}{|l|}{ Bldg Number: } \\
\hline \multicolumn{5}{|l|}{ Building Name: } \\
\hline \multicolumn{5}{|l|}{ Building Use Type: } \\
\hline \multicolumn{5}{|l|}{ Year Constructed } \\
\hline \multicolumn{5}{|l|}{ Number Floors } \\
\hline \multirow{2}{*}{\multicolumn{5}{|c|}{$\begin{array}{l}\text { POC Name: } \\
\text { Assessor Name: }\end{array}$}} \\
\hline & & & & \\
\hline \multicolumn{5}{|l|}{ Assessment Date: } \\
\hline \multicolumn{5}{|l|}{ Note: * Denotes Requirement } \\
\hline \multicolumn{2}{|l|}{ Issue: Location } & & \multicolumn{2}{|l|}{ Date: } \\
\hline \multicolumn{2}{|l|}{ Sub-Issue } & & Rating & Density \\
\hline \multicolumn{2}{|l|}{ Floodplain } & & $G / A / R$ & $N / A$ \\
\hline \multicolumn{2}{|l|}{ Airfield Safety Clearance } & & $G / A / R$ & $N / A$ \\
\hline \multicolumn{2}{|l|}{ Explosive Arc } & & $G / A / R$ & $N / A$ \\
\hline \multicolumn{2}{|l|}{ Excessive Noise } & & $G / A / R$ & $N / A$ \\
\hline \multicolumn{2}{|c|}{ Adequate for Mission Support } & & $G / A / R$ & $N / A$ \\
\hline \multicolumn{2}{|l|}{ Building Size and configuration } & & Date: & \\
\hline \multicolumn{2}{|l|}{ Sub-Issue } & & Rating & Density \\
\hline \multicolumn{2}{|l|}{ Occupancy Interaction } & & $G / A / R$ & $\%$ \\
\hline \multicolumn{2}{|l|}{ Overcrowding } & & $G / A / R$ & $\%$ \\
\hline \multicolumn{2}{|l|}{ Configuration } & & $G / A / R$ & $\%$ \\
\hline \multicolumn{2}{|l|}{ Structural Adequacy } & & Date: & \\
\hline \multicolumn{2}{|l|}{ Sub-Issue } & & Rating & Density \\
\hline \multicolumn{2}{|l|}{ Seismic } & & $G / A / R$ & $\%$ \\
\hline \multicolumn{2}{|l|}{ Other Loading Conditions } & & $G / A / R$ & $\%$ \\
\hline Access & POC: & & Date: & \\
\hline \multicolumn{2}{|l|}{ Sub-Issue } & & Rating & Density \\
\hline \multicolumn{2}{|l|}{ Building Entry } & & Green & $\%$ \\
\hline \multicolumn{2}{|l|}{ Directional Information } & & Amber & $\%$ \\
\hline Egress & & & Red & $\%$ \\
\hline
\end{tabular}




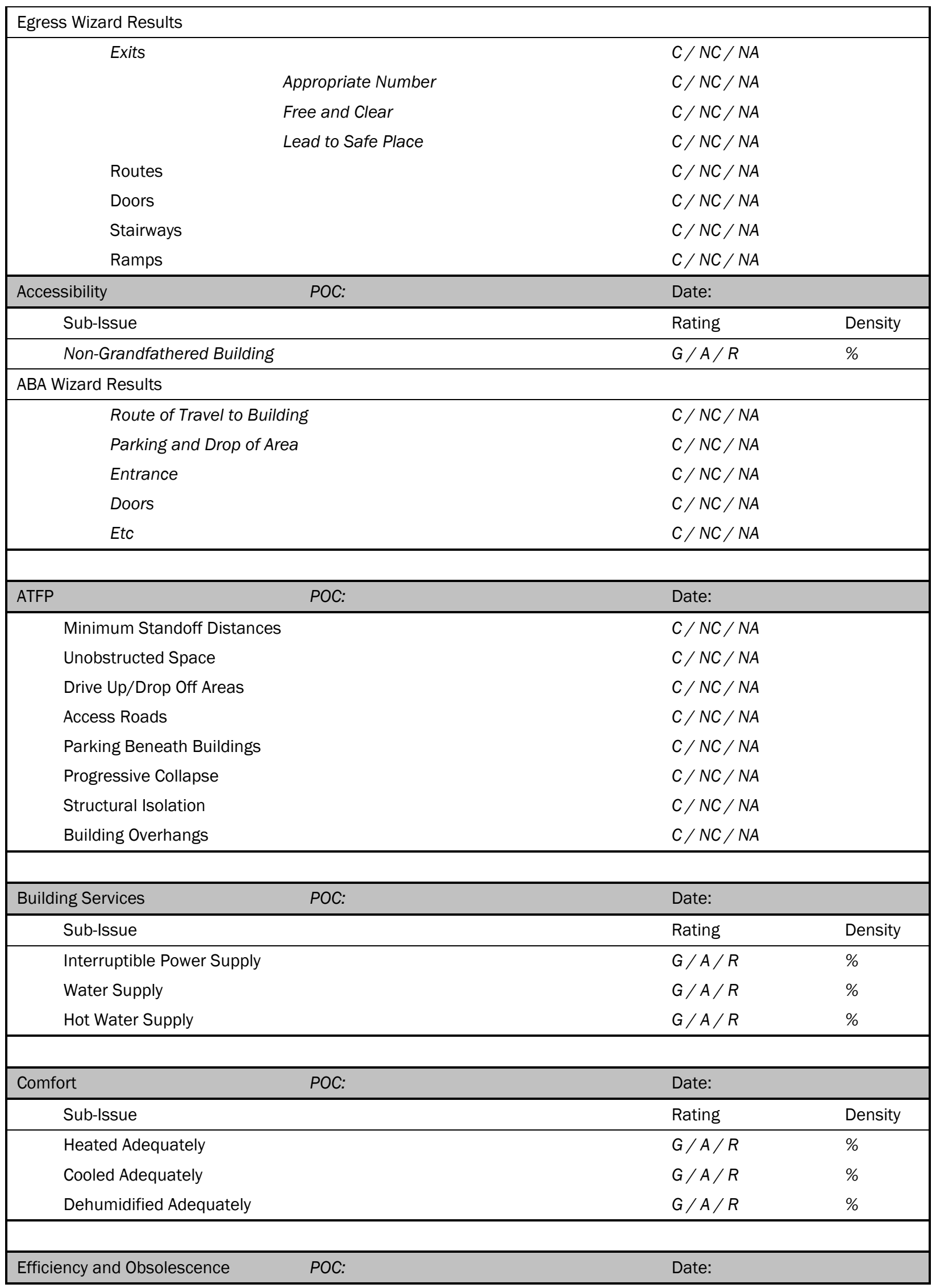




\begin{tabular}{|c|c|c|}
\hline Sub-Issue & Rating & Density \\
\hline Equipment Energy Efficient & $G / A / R$ & $\%$ \\
\hline \multicolumn{3}{|l|}{ Efficiency Wizard Results } \\
\hline Electrical & Non-Efficient & \\
\hline HVAC & Non-Efficient & \\
\hline Other & Non-Efficient & \\
\hline Adequately Zoned & $G / A / R$ & $\%$ \\
\hline Efficient Lighting Controls & $G / A / R$ & $\%$ \\
\hline Efficient Lighting Fixtures & $G / A / R$ & $\%$ \\
\hline Water Conservation Mechanisms & $G / A / R$ & $\%$ \\
\hline Energy Efficient Windows and Doors & $G / A / R$ & $\%$ \\
\hline Building Insulation & $G / A / R$ & $\%$ \\
\hline Environmental/Health & Date: & \\
\hline Sub-Issue & Rating & Density \\
\hline Lightning Protection & $G / A / R$ & $\%$ \\
\hline Asbestos & $G / A / R$ & $\%$ \\
\hline Indoor Air Quality & $G / A / R$ & $\%$ \\
\hline Lead Paint & $G / A / R$ & $\%$ \\
\hline Lead Water Levels & $G / A / R$ & $\%$ \\
\hline PCBs & $G / A / R$ & $\%$ \\
\hline Radon & $G / A / R$ & $\%$ \\
\hline Fire Detection System & $G / A / R$ & $\%$ \\
\hline Fire Suppression Equipment & $G / A / R$ & $\%$ \\
\hline Combustible Materials Storage & $G / A / R$ & $\%$ \\
\hline Missing or improper components $\quad$ POC: & Date: & \\
\hline Sub-Issue & Rating & Density \\
\hline Missing Components & $G / A / R$ & $\%$ \\
\hline Incorrect Component Types & $G / A / R$ & $\%$ \\
\hline
\end{tabular}




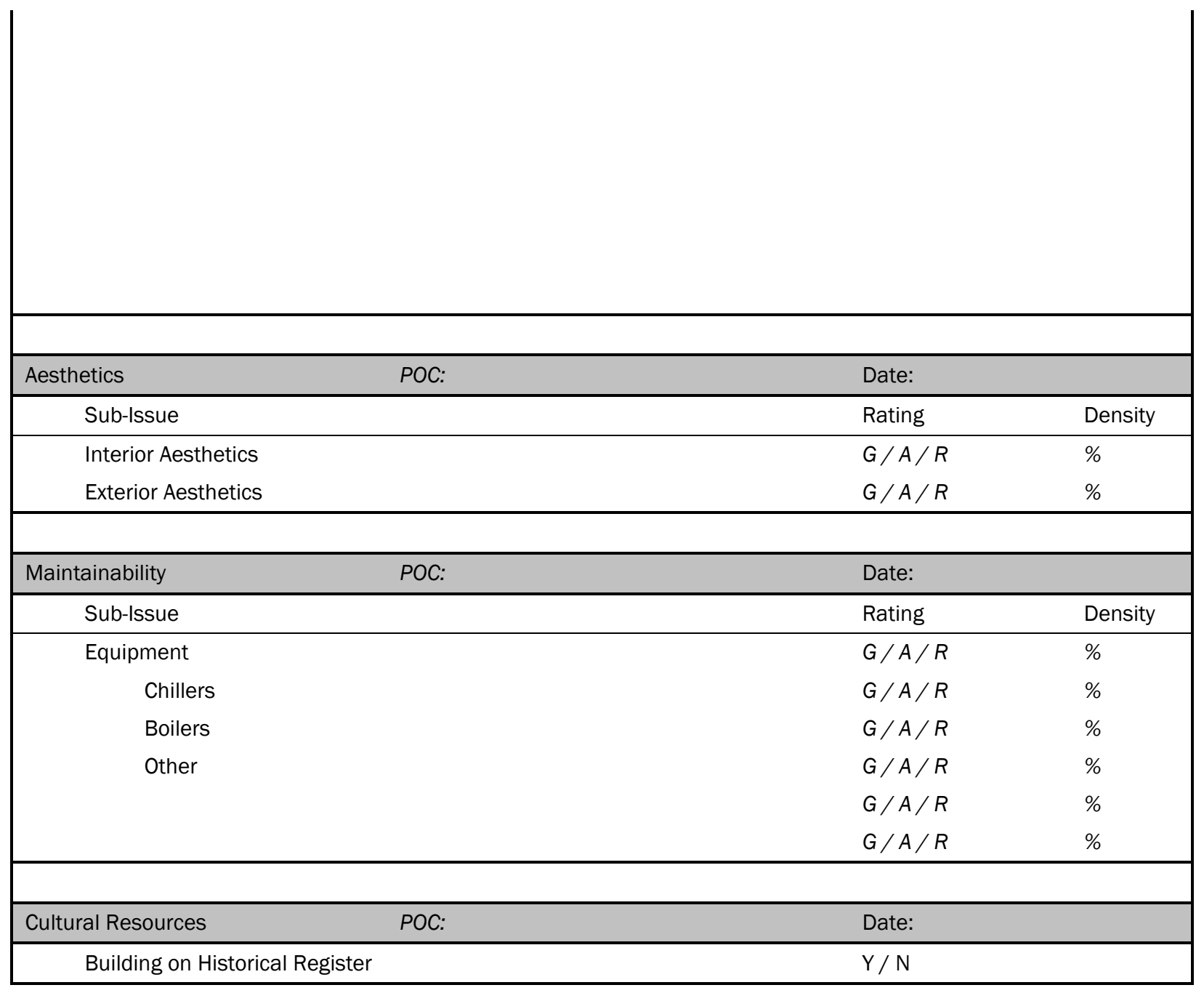




\section{Appendix D: Army Standard Design Criteria for Brigade Headquarters Facility}

\begin{tabular}{|c|c|c|}
\hline \multicolumn{3}{|c|}{ Brigade Headquarters - General } \\
\hline Components Affected & Issue & Requirement \\
\hline Building Construction & Meets Code & $\begin{array}{l}\text { Building shall be constructed to } \\
\text { meet UFC 3-600-01, the } \\
\text { international Building Code and } \\
\text { NFPA } 101\end{array}$ \\
\hline Fire Extinguishers & Provided & $\begin{array}{l}\text { Should be provided when } \\
\text { required by UFC 3-600-01 }\end{array}$ \\
\hline Buildings & Location & $\begin{array}{l}\text { Should be located within an } \\
\text { operations complex along with } \\
\text { Company Operations Facilities } \\
\text { (COF) and Tactical Equipment } \\
\text { Maintenance Facilities (motor } \\
\text { pools, TEMF) }\end{array}$ \\
\hline Buildings & Location & $\begin{array}{l}\text { Within walking distance of } \\
\text { community facilities such as } \\
\text { barracks and dining facilities. }\end{array}$ \\
\hline Buildings & Size & $\begin{array}{l}\text { Maximum gross area limits } \\
\text { indicated in Paragraph } 2.0 \text {, } \\
\text { SCOPE, may not be exceeded. A } \\
\text { smaller gross area is } \\
\text { permissible given all net area } \\
\text { program requirements are met. }\end{array}$ \\
\hline Workstations & $\begin{array}{l}\text { Network } \\
\text { Access }\end{array}$ & $\begin{array}{l}\text { All workstations shall have data } \\
\text { and voice connectivity } \\
\text { capability. }\end{array}$ \\
\hline Building & Accessibility & Is building ABA compliant? \\
\hline $\begin{array}{l}\text { Telecommunications } \\
\text { Outlets }\end{array}$ & Configuration & $\begin{array}{l}\text { One outlet per person assuming } \\
36 \text { square feet/person }\end{array}$ \\
\hline $\begin{array}{l}\text { Telecommunications } \\
\text { Outlets }\end{array}$ & & 13A Guidelines \\
\hline $\begin{array}{l}\text { Telecommunications } \\
\text { Outlets }\end{array}$ & Underground & $\begin{array}{l}\text { Underground to Main } \\
\text { installation equipment room. }\end{array}$ \\
\hline $\begin{array}{l}\text { Telecommunications } \\
\text { Outlets }\end{array}$ & Compliant & $\begin{array}{l}\text { Outlets compliance with } 13 \mathrm{~A} \\
\text { technical guide }\end{array}$ \\
\hline $\begin{array}{l}\text { Telecommunications } \\
\text { Outlets }\end{array}$ & Compliant & $\begin{array}{l}\text { SCIF compliant with DCID 6/9, } \\
\text { Annex G or Intelligence } \\
\text { Community Directive }\end{array}$ \\
\hline $\begin{array}{l}\text { Telecommunications } \\
\text { Outlets }\end{array}$ & & $\begin{array}{l}\text { Data outlets per } 13 \mathrm{~A} \text { - user } \\
\text { special ops requirements }\end{array}$ \\
\hline Antenna Systems & Location & $\begin{array}{l}\text { Accommodation for line-of-sight } \\
\text { to geostationary equatorial } \\
\text { satellites }\end{array}$ \\
\hline
\end{tabular}

Reference Code 


\begin{tabular}{|c|c|c|}
\hline $\begin{array}{l}\text { Secure Document } \\
\text { Storage }\end{array}$ & Meets Code & $\begin{array}{l}\text { Secure documents storage IAW } \\
\text { AR } 380-5 \text { requirements }\end{array}$ \\
\hline $\begin{array}{l}\text { Secure Video } \\
\text { Conferencing }\end{array}$ & Security & $\begin{array}{l}\text { Secure VTC in command } \\
\text { conference room }\end{array}$ \\
\hline $\begin{array}{l}\text { Secure Video } \\
\text { Conferencing }\end{array}$ & Security & Secure VTC in BOC \\
\hline $\begin{array}{l}\text { Secure Video } \\
\text { Conferencing }\end{array}$ & Security & Secure VTC in SCIF \\
\hline Private Offices & Size & $\begin{array}{l}\text { Number specified by Brigade } \\
\text { Size }\end{array}$ \\
\hline Emergency Power & Backup & $\begin{array}{l}\text { Backup power auto switch for } \\
\text { power list and HVAC in Coms } \\
\text { Rooms, Server Room, BOC, } \\
\text { NOC, SCIF, TSOA }\end{array}$ \\
\hline
\end{tabular}

\begin{tabular}{|c|c|c|c|}
\hline \multicolumn{4}{|c|}{ Brigade Headquarters - BOC (if required) determined by TOE } \\
\hline Components Affected & Issue & Requirement & Reference Code \\
\hline Floor & Configuration & $\begin{array}{l}\text { Raised access flooring or On } \\
\text { ground flooring }\end{array}$ & \\
\hline \multicolumn{4}{|c|}{ Brigade Headquarters - NOC } \\
\hline Components Affected & Issue & Requirement & Reference Code \\
\hline Floor & Configuration & $\begin{array}{l}\text { Raised access flooring or On } \\
\text { ground flooring }\end{array}$ & \\
\hline \multicolumn{4}{|c|}{ Brigade Headquarters - SCIF } \\
\hline Components Affected & Issue & Requirement & Reference Code \\
\hline Floor & Configuration & $\begin{array}{l}\text { Raised access flooring or On } \\
\text { ground flooring }\end{array}$ & \\
\hline \multirow[t]{4}{*}{ Intrusion Detection } & Security & $\begin{array}{l}\text { Access control and intrusion } \\
\text { detection for monitoring and } \\
\text { controlling access }\end{array}$ & \\
\hline & Access & Ground level access to the TSOA & \\
\hline & Security & $\begin{array}{l}\text { Protection from surreptitious } \\
\text { entry }\end{array}$ & \\
\hline & Security & Protection from forced entry & \\
\hline \multirow[t]{4}{*}{ Insulation } & Sound Proof & $\begin{array}{l}\text { Protection form Classified } \\
\text { discussions being heard outside }\end{array}$ & \\
\hline & Security & $\begin{array}{l}\text { Protection from Implantation of } \\
\text { technical surveillance devices }\end{array}$ & \\
\hline & Security & $\begin{array}{l}\text { Protection from visual } \\
\text { observation }\end{array}$ & \\
\hline & Security & $\begin{array}{l}\text { Protection from stand-off } \\
\text { technical attack }\end{array}$ & \\
\hline \multicolumn{4}{|c|}{ Brigade Headquarters - Tactical SCIF Operations Areas (TSOA) } \\
\hline \multirow[t]{4}{*}{ Components Affected } & Issue & Requirement & Reference Code \\
\hline & & Ground floor location & \\
\hline & Location & Adjacent to the permanent SCIF & \\
\hline & & $\begin{array}{l}\text { Vehicle shelters IAW DCID 6/9 } \\
\text { or ICD } 704\end{array}$ & \\
\hline
\end{tabular}




\begin{tabular}{|c|c|c|c|}
\hline & & $\begin{array}{l}\text { Telecom routed through } \\
\text { DIA/DAC- } 22 \text { approved PDS from } \\
\text { Perm SCIF to TSOA }\end{array}$ & \\
\hline & & $\begin{array}{l}\text { Fenced with CCTV monitored } \\
24 / 7 \text {, locks, access control, } \\
\text { intrusion detection }\end{array}$ & \\
\hline Parking & Availability & $\begin{array}{l}\text { Parking area for tow HMMWV } \\
\text { vehicles with trailer provided } \\
\text { adjacent to SCIF. }\end{array}$ & \\
\hline Fencing & Security & $\begin{array}{l}\text { A perimeter fence consisting of } \\
\text { a } 6 \text {-foot high chain link fabric } \\
\text { topped by a single outrigger with } \\
\text { three-strand barbed wire } \\
\text { designed in accordance with } \\
\text { STD 872-90-03, FE-6. }\end{array}$ & STD 872-90-03, FE-6 \\
\hline Pavement & Size & $\begin{array}{l}\text { Provide } 30 \text {-foot wide by } 40 \text { foot } \\
\text { long rigid concrete pavement } \\
\text { designed to support HMMWV } \\
\text { vehicles with trailers }\end{array}$ & \\
\hline Landscape & Spacing & $\begin{array}{l}\text { A } 10 \text {-foot wide zone clear of } \\
\text { trees and shrubs is required on } \\
\text { each side of the fence. Should } \\
\text { require minimal maintenance, } \\
\text { and the area } 5 \text { feet each side of } \\
\text { the fence should have gravel. }\end{array}$ & \\
\hline Transformers & Location & Not above ground in this area & \\
\hline Generators & Location & Not above ground in this area & \\
\hline $\begin{array}{l}\text { Mechanical } \\
\text { Equipment }\end{array}$ & Location & Not above ground in this area & \\
\hline
\end{tabular}

\section{Brigade Headquarters - Physical Security Zones}

Security Zone 1 - limited access for physical and personnel security for:

Security Zone 2 - Controlled access for operational \& information security for:

Security Zone 3 - Restricted access with electronic access control (BOC, NOC, SCIF, TSOA)

$\begin{array}{lll}\text { Brigade Headquarters - Administrative Facilities } \\ \text { Components Affected } & \text { Issue } & \text { Requirement } \\ \text { Interior Construction } & \text { Configuration } & \begin{array}{l}\text { Provide centralized areas for } \\ \text { photocopier, laser printer and } \\ \text { fax machine with waste and } \\ \text { paper recycling receptacles and } \\ \end{array} \\ & \text { supply cabinet for paper storage } \\ & \text { in each office area. }\end{array}$




\begin{tabular}{|c|c|c|c|}
\hline \multicolumn{4}{|c|}{ Brigade Headquarters - Showers } \\
\hline Components Affected & Issue & Requirement & Reference Code \\
\hline Showers & Provided & $\begin{array}{l}\text { Provide } 1 \text { female shower and } 2 \\
\text { male shower }\end{array}$ & \\
\hline \multicolumn{4}{|c|}{ Brigade Headquarters - Staff Duty Station } \\
\hline Components Affected & Issue & Requirement & Reference Code \\
\hline Staff Duty Station & Location & $\begin{array}{l}\text { Located at each } \\
\text { entrance/reception area }\end{array}$ & \\
\hline \multicolumn{4}{|c|}{ Brigade Headquarters - Exterior Lighting } \\
\hline Components Affected & Issue & Requirement & Reference Code \\
\hline Exterior Lighting & Access & $\begin{array}{l}\text { Sidewalks, service yards and } \\
\text { parking areas shall have } \\
\text { exterior lighting. }\end{array}$ & \\
\hline \multicolumn{4}{|c|}{ Brigade Headquarters - Privately Owned Vehicles (POV) Parking } \\
\hline Components Affected & Issue & Requirement & Reference Code \\
\hline Parking & Availability & $\begin{array}{l}\text { POV parking to be provided at } \\
\text { the ratio of one space for } 90 \% \\
\text { of the intended HQ staff } \\
\text { capacity }\end{array}$ & \\
\hline
\end{tabular}

$\begin{array}{llll}\text { Brigade Headquarters } & \text { - Building Entrances } & \\ \text { Components Affected } & \text { Issue } & \text { Requirement } & \text { Reference Code } \\ \text { Building Entrance } & \text { Aesthetics } & \text { Provide attractive entry features } & \\ & & \text { such as canopies and large } & \\ & & \text { glass wall surfaces, ensuring } \\ & \text { compliance with Anti- } \\ & \text { Terrorism/Force Protection } \\ & \text { requirements. }\end{array}$

\begin{tabular}{|c|c|c|c|}
\hline \multicolumn{4}{|c|}{ Brigade Headquarters - Office and Admin Areas } \\
\hline Components Affected & Issue & Requirement & Reference Code \\
\hline Staff Sections & Configuration & $\begin{array}{l}\text { Office sections should be } \\
\text { separated by walls or floors. }\end{array}$ & \\
\hline Private Offices & Configuration & $\begin{array}{l}\text { Private offices should be } \\
\text { separated by walls or floors and } \\
\text { should have doors for privacy. }\end{array}$ & \\
\hline Command Offices & Configuration & $\begin{array}{l}\text { Should be built as a more } \\
\text { permanent construction with } \\
\text { sound insulation, but still with } \\
\text { minimal load bearing walls so } \\
\text { as to accommodate future } \\
\text { reconfiguration. }\end{array}$ & \\
\hline Headquarters & Configuration & $\begin{array}{l}\text { Should be built as a more } \\
\text { permanent construction with } \\
\text { sound insulation, but still with } \\
\text { minimal load bearing walls so } \\
\text { as to accommodate future } \\
\text { reconfiguration. }\end{array}$ & \\
\hline
\end{tabular}

\section{Brigade Headquarters - Message Center}

Components Affected Issue

Mail Room

Security

\section{Requirement}

Reference Code

Provide adequate security for mail storage and distribution. 


\begin{tabular}{|c|c|c|}
\hline Doors & Components & $\begin{array}{l}\text { Structural requirements are as } \\
\text { follows: Provide doors with } \\
\text { suitable locks and door hinges. }\end{array}$ \\
\hline Lock & & $\begin{array}{l}\text { Shall be key-operated, mortised, } \\
\text { or rim-mounted lock; have a } \\
\text { dead bolt throw one inch; be a } \\
\text { double cylinder design; have } \\
\text { five pin tumbler cylinders; with } \\
\text { two of mushroom or spool-type } \\
\text { drive pin design. }\end{array}$ \\
\hline Windows & Security & $\begin{array}{l}\text { Ground-level windows shall } \\
\text { have bars. }\end{array}$ \\
\hline Windows & Security & $\begin{array}{l}\text { Cover above ground level } \\
\text { windows with wire mesh } \\
\text { security screen. }\end{array}$ \\
\hline Walls & Material & $\begin{array}{l}\text { Shall be made of material to } \\
\text { prevent forcible entry. }\end{array}$ \\
\hline Ceilings & Material & $\begin{array}{l}\text { Shall be made of material to } \\
\text { prevent forcible entry. }\end{array}$ \\
\hline Security System & Provided & $\begin{array}{l}\text { Provide provisions for ICIDS } \\
\text { (Internal Commercial Intrusion } \\
\text { Detection System) in facilities } \\
\text { that are not operational on a } \\
\text { 24-hour basis. }\end{array}$ \\
\hline
\end{tabular}

\section{Brigade Headquarters - Secure Documents Room}

\begin{tabular}{|c|c|c|c|}
\hline Components Affected & Issue & Requirement & Reference Code \\
\hline $\begin{array}{l}\text { Secure Documents } \\
\text { Room }\end{array}$ & Configuration & $\begin{array}{l}\text { Located in the S- } 2 \text { area of } \\
\text { building and constructed in } \\
\text { accordance with AR } 380-5 \text { and } \\
\text { classified for Open Storage. }\end{array}$ & AR 380-5 \\
\hline
\end{tabular}

\begin{tabular}{|c|c|c|c|}
\hline \multicolumn{4}{|c|}{ Brigade Headquarters - Network Operations Center } \\
\hline Components Affected & Issue & Requirement & Reference Code \\
\hline $\begin{array}{l}\text { Network Operations } \\
\text { Center }\end{array}$ & Configuration & $\begin{array}{l}\text { The NOC shall be designed and } \\
\text { constructed as a secure room in } \\
\text { accordance with AR } 380-5 \text { and } \\
\text { classified for Open Storage }\end{array}$ & AR 380-5 \\
\hline
\end{tabular}

\section{Brigade Headquarters - Brigade Operations Center}

Components Affected

Issue

Requirement

Reference Code

Brigade Operations Configuration The BOC will accommodate Gov-

Center

Furn television screens and monitors. Designed and constructed as a secure room in accordance with AR 380-5 and classified for Open Storage.

\section{Brigade Headquarters - Sensitive Compartmented Information Facility}

Components Affected

Sensitive

Compartmented

Information Facility

\section{Requirement}

Reference Code 


\begin{tabular}{|c|c|c|c|}
\hline \multicolumn{4}{|c|}{ Brigade Headquarters - Telecommunications Rooms } \\
\hline Components Affected & Issue & Requirement & Reference Code \\
\hline HVAC & Provided & $\begin{array}{l}\text { Served by an independent and } \\
\text { dedicated air-handling system. } \\
\text { Air handling system(s) shall not } \\
\text { be floor-space mounted within } \\
\text { the actual space served. }\end{array}$ & \\
\hline Network & Provided & $\begin{array}{l}\text { Space for classified network, } \\
\text { unclassified network, and voice. } \\
\text { Space shall be added for users } \\
\text { secure and non-secure } \\
\text { telecommunications equipment } \\
\text { such as Private Branch } \\
\text { Exchange (PBX), network } \\
\text { switches, routers, servers, and } \\
\text { storage. }\end{array}$ & \\
\hline Room & Size & $\begin{array}{l}\text { Sized and designed in } \\
\text { accordance with the } 13 \mathrm{~A} \text { guide } \\
\text { and ANSI/EAI/TIA-569-B. } \\
\text { Approximate allocation (total of } \\
\text { all rooms) shall be } 2 \text { percent of } \\
\text { the net building area. }\end{array}$ & \\
\hline Room & Location & Locate in a lower level. & \\
\hline Room & Construction & $\begin{array}{l}\text { Plywood backboard ( } 3 / 4 \text { inch } \\
\text { thick) around interior perimeter. }\end{array}$ & \\
\hline \multirow[t]{2}{*}{ Room } & Configuration & $\begin{array}{l}\text { Three foot wide door opening } \\
\text { out of the room. }\end{array}$ & \\
\hline & & $\begin{array}{l}\text { [(Brigade Headquarters Only) } \\
\text { Dedicated emergency power } \\
\text { panel for all active equipment.] }\end{array}$ & \\
\hline \multirow[t]{2}{*}{ Lighting } & Brightness & 50 foot-candle & \\
\hline & & $\begin{array}{l}\text { Accessed from within the } \\
\text { building. No exterior access } \\
\text { shall be provided. }\end{array}$ & \\
\hline Cabinets & Security & $\begin{array}{l}\text { Lockable cabinets shall be } \\
\text { provided for security } \\
\text { classification segregation. }\end{array}$ & \\
\hline
\end{tabular}

\section{Brigade Headquarters - Secure Communications Rooms}

Components Affected

HVAC

Room

\section{Issue}

Provided

Configuration
Requirement

Reference Code
Served by an independent and dedicated air-handling system. Air handling system(s) shall not be floor-space mounted within the actual space served.

Designed and Constructed in accordance with the Technical Guide for the Integration of Secret Internet Protocol Router Network. Minimum size shall be 6'x6' 
Signal Ground Busbar

SIPRNet

Secure Video

Teleconferencing

$\begin{array}{lll}\text { JWICS } & \text { Present } & \begin{array}{l}\text { Joint Worldwide Intelligence } \\ \text { Communications System } \\ \text { (JWICS) }\end{array} \\ \text { SIPRNet } & \text { Present } & \begin{array}{l}\text { Secret Internet Protocol Router } \\ \text { Network (SIPRNet) }\end{array}\end{array}$

Brigade Headquarters - Other Site Features

Components Affected Issue

Fire Protection

Meets Code

All fire protection and life safety features shall be in accordance with UFC 3-600-01 and the criteria referenced therein.

Sprinkler System Provided

The facility shall be fully protected with automatic sprinkler systems. All floors and all areas of the facilities shall be protected. The sprinkler design shall be in accordance with UFC

Sprinkler System Drainage

Sprinkler Service Main and Riser
Each room shall include a communication signal ground usbar, connected to the main properly sized ground wire (see MIL-HDBK-419-A) and one dedicated 20-amp circuit for the SIPRNet rack/safe. Secure Internet Protocol Routing Network (SIPRNet) access, installed in accordance provisions of Technical SIPRNet.

each Battalion Headquarters

Command Conference Room and each Brigade Headquarters Command Conference Room, BOC and SCIF.

Communications System Network (SIPRNet)

\section{3-600-01 and NFPA 13}

All sprinkler system drains, including main drains, test drains, and auxiliary drains, shall be routed to a 2 - foot by 2 foot splash block at exterior grade.

Water Supply The sprinkler service main shall be a dedicated line from the distribution main. Sprinkler service and domestic service shall not be combined.
UFC 3-600-01

UFC 3-600-01, NFPA 13 


\begin{tabular}{|c|c|c|c|}
\hline $\begin{array}{l}\text { Sprinkler Service } \\
\text { Main and Riser }\end{array}$ & Signage & $\begin{array}{l}\text { The sprinkler service main shall } \\
\text { be provided with an exterior } \\
\text { post indicator valve with tamper } \\
\text { switch reporting to the fire } \\
\text { alarm control panel (FACP) }\end{array}$ & \\
\hline $\begin{array}{l}\text { Sprinkler Service } \\
\text { Main and Riser }\end{array}$ & Components & $\begin{array}{l}\text { Ground floor entry penetration } \\
\text { shall be sleeved per NFPA } 13 \\
\text { requirements for seismic } \\
\text { protection. }\end{array}$ & NFPA 13 \\
\hline $\begin{array}{l}\text { Sprinkler Service } \\
\text { Main and Riser }\end{array}$ & Components & $\begin{array}{l}\text { All control valves shall be OS\&Y } \\
\text { gate type and shall be provided } \\
\text { with tamper switches connected } \\
\text { to the FACP. }\end{array}$ & \\
\hline $\begin{array}{l}\text { Sprinkler Service } \\
\text { Main and Riser }\end{array}$ & Components & $\begin{array}{l}\text { The floor control valve assembly } \\
\text { shall be in accordance with UFC } \\
3-600-01\end{array}$ & \\
\hline Exterior Hose Stream & Capacity & $\begin{array}{l}\text { Exterior hose stream demand } \\
\text { shall be in accordance with UFC } \\
3-600-01 \text {. This shall be } 250 \\
\text { GPM for light hazard and } 500 \\
\text { GPM for ordinary hazard. }\end{array}$ & UFC 3-600-01 \\
\hline Backflow Preventer & Components & $\begin{array}{l}\text { Double check valve backflow } \\
\text { preventer shall be provided on } \\
\text { the fire water main serving each } \\
\text { building. }\end{array}$ & \\
\hline Backflow Preventer & Location & Located within the building. & \\
\hline Backflow Preventer & Components & $\begin{array}{l}\text { OS\&Y valves and meets NFPA } \\
13 \text { requirements }\end{array}$ & NFPA 13 \\
\hline $\begin{array}{l}\text { Fire Department } \\
\text { Connection }\end{array}$ & Provided & $\begin{array}{l}\text { A fire department connection } \\
\text { shall be provided for each } \\
\text { building with sprinkler } \\
\text { protection. These shall be } \\
\text { located to be directly accessible } \\
\text { to the fire department. }\end{array}$ & \\
\hline Elevators & Provided & $\begin{array}{l}\text { The fire protection features of } \\
\text { elevators, hoist ways, machine } \\
\text { rooms and lobbies shall be in } \\
\text { accordance with UFC 3-600-01, } \\
\text { ASME A17.1, NFPA 13, NFPA } 72\end{array}$ & $\begin{array}{l}\text { UFC 3-600-01, ASME } \\
\text { A17.1, NFPA 13, NFPA } 72\end{array}$ \\
\hline $\begin{array}{l}\text { Sprinkler System } \\
\text { Hardware }\end{array}$ & Components & $\begin{array}{l}\text { Materials for the sprinkler } \\
\text { system, fire pump system, and } \\
\text { hose standpipe system shall be } \\
\text { in accordance with NFPA } 13 \text {, } \\
\text { NFPA } 20\end{array}$ & NFPA 13, NFPA 20 \\
\hline $\begin{array}{l}\text { Earthquake Piping } \\
\text { Protection }\end{array}$ & Components & $\begin{array}{l}\text { Sprinkler and fire pump piping } \\
\text { systems shall be protected } \\
\text { against damage from } \\
\text { earthquakes. Flexible and rigid } \\
\text { couplings, sway bracing, seismic } \\
\text { separation assemblies at } \\
\text { seismic separation joints as } \\
\text { required by NFPA } 13\end{array}$ & NFPA 13 \\
\hline Fire Water Supply & Capacity & $\begin{array}{l}\text { Fire test flow data provided in } \\
\text { Appendix } D\end{array}$ & Appendix D \\
\hline
\end{tabular}


Fire Pump

Meets Code

Comply with requirements of UFC 3-600-01, NFPA 13, NFPA

20
UFC 3-600-01, NFPA 13, NFPA 20 


\section{Appendix E: Army Standard Design Criteria for Battalion Headquarters Facility}

\begin{tabular}{|c|c|c|}
\hline $\begin{array}{l}\text { General Building } \\
\text { Components Affected }\end{array}$ & Issue & Requirement \\
\hline Physical Security & Security & $\begin{array}{l}\text { Zone } 1 \text { - limited access for physical and personnel } \\
\text { security for: }\end{array}$ \\
\hline Physical Security & Security & $\begin{array}{l}\text { Zone } 2 \text { - Controlled access for operational and } \\
\text { information security for: }\end{array}$ \\
\hline $\begin{array}{l}\text { Video } \\
\text { Teleconferencing }\end{array}$ & Components & VTC provide in command conference room \\
\hline Private offices & Size & 13 total \\
\hline Building Construction & Meets Code & $\begin{array}{l}\text { Building shall be constructed to meet UFC 3-600- } \\
01 \text {, the international Building Code and NFPA } 101\end{array}$ \\
\hline Fire Extinguishers & Provided & $\begin{array}{l}\text { Should be provided when required by UFC 3-600- } \\
01\end{array}$ \\
\hline Buildings & Location & $\begin{array}{l}\text { Should be located within an operations complex } \\
\text { along with Company Operations Facilities (COF) } \\
\text { and Tactical Equipment Maintenance Facilities } \\
\text { (motor pools, TEMF) }\end{array}$ \\
\hline Buildings & Location & $\begin{array}{l}\text { Within walking distance of community facilities } \\
\text { such as barracks and dining facilities. }\end{array}$ \\
\hline Buildings & Size & $\begin{array}{l}\text { Maximum gross area limits indicated in Paragraph } \\
2.0, \mathrm{SCOPE} \text {, may not be exceeded. A smaller } \\
\text { gross area is permissible given all net area } \\
\text { program requirements are met. }\end{array}$ \\
\hline Workstations & $\begin{array}{l}\text { Network } \\
\text { Access }\end{array}$ & $\begin{array}{l}\text { All workstations shall have data and voice } \\
\text { connectivity capability. }\end{array}$ \\
\hline Building & Access & Is building ABA compliant? \\
\hline $\begin{array}{l}\text { Telecommunications } \\
\text { Outlets }\end{array}$ & Configuration & $\begin{array}{l}\text { One outlet per person assuming } 36 \text { square } \\
\text { feet/person }\end{array}$ \\
\hline $\begin{array}{l}\text { Telecommunications } \\
\text { Outlets }\end{array}$ & & 13A Guidelines \\
\hline $\begin{array}{l}\text { Telecommunications } \\
\text { Outlets }\end{array}$ & Underground & $\begin{array}{l}\text { Underground to Main installation equipment } \\
\text { room. }\end{array}$ \\
\hline $\begin{array}{l}\text { Telecommunications } \\
\text { Outlets }\end{array}$ & Compliant & Outlets compliance with $13 \mathrm{~A}$ technical guide \\
\hline $\begin{array}{l}\text { Telecommunications } \\
\text { Outlets }\end{array}$ & Compliant & $\begin{array}{l}\text { SCIF compliant with DCID 6/9, Annex G or } \\
\text { Intelligence Community Directive }\end{array}$ \\
\hline $\begin{array}{l}\text { Telecommunications } \\
\text { Outlets }\end{array}$ & & $\begin{array}{l}\text { Data outlets per } 13 \mathrm{~A} \text { - user special ops } \\
\text { requirements }\end{array}$ \\
\hline
\end{tabular}




\begin{tabular}{|c|c|c|c|}
\hline $\begin{array}{l}\text { Administrative Facilities } \\
\text { Components Affected }\end{array}$ & Issue & Requirement & Reference Code \\
\hline Interior Construction & Configuration & $\begin{array}{l}\text { Provide centralized areas for photocopier, laser } \\
\text { printer and fax machine with waste and paper } \\
\text { recycling receptacles and supply cabinet for paper } \\
\text { storage in each office area. }\end{array}$ & \\
\hline \multicolumn{4}{|l|}{ Showers } \\
\hline Components Affected & Issue & Requirement & Reference Code \\
\hline Showers & Provided & Provide 1 female shower and 2 male shower & \\
\hline \multicolumn{4}{|l|}{ Staff Duty Station } \\
\hline Components Affected & Issue & Requirement & Reference Code \\
\hline Staff Duty Station & Location & Located at each entrance/reception area & \\
\hline \multicolumn{4}{|c|}{ Tactical SCIF Operation Areas } \\
\hline Components Affected & Issue & Requirement & Reference Code \\
\hline Parking & Availability & $\begin{array}{l}\text { Parking area for tow HMMWV vehicles with trailer } \\
\text { provided adjacent to SCIF. }\end{array}$ & \\
\hline Fencing & Security & $\begin{array}{l}\text { A perimeter fence consisting of a 6-foot high chain } \\
\text { link fabric topped by a single outrigger with three- } \\
\text { strand barbed wire designed in accordance with } \\
\text { STD 872-90-03, FE-6. }\end{array}$ & STD 872-90-03, FE-6 \\
\hline Pavement & Size & $\begin{array}{l}\text { Provide } 30 \text {-foot wide by } 40 \text { foot long rigid } \\
\text { concrete pavement designed to support HMMWV } \\
\text { vehicles with trailers }\end{array}$ & \\
\hline Landscape & Spacing & $\begin{array}{l}\text { A } 10 \text {-foot wide zone clear of trees and shrubs is } \\
\text { required on each side of the fence. Should require } \\
\text { minimal maintenance, and the area } 5 \text { feet each } \\
\text { side of the fence should have gravel. }\end{array}$ & \\
\hline Transformers & Location & Not above ground in this area & \\
\hline Generators & Location & Not above ground in this area & \\
\hline $\begin{array}{l}\text { Mechanical } \\
\text { Equipment }\end{array}$ & Location & Not above ground in this area & \\
\hline \multicolumn{4}{|l|}{ Exterior Lighting } \\
\hline Components Affected & Issue & Requirement & Reference Code \\
\hline Exterior Lighting & Access & $\begin{array}{l}\text { Sidewalks, service yards and parking areas shall } \\
\text { have exterior lighting. }\end{array}$ & \\
\hline \multicolumn{4}{|c|}{ Privately Owned Vehicles (POV) Parking } \\
\hline Components Affected & Issue & Requirement & Reference Code \\
\hline Parking & Availability & $\begin{array}{l}\text { POV parking to be provided at the ratio of one } \\
\text { space for } 90 \% \text { of the intended HQ staff capacity }\end{array}$ & \\
\hline \multicolumn{4}{|l|}{ Building Entrance } \\
\hline Components Affected & Issue & Requirement & Reference Code \\
\hline Building Entrance & Aesthetics & $\begin{array}{l}\text { Provide attractive entry features such as canopies } \\
\text { and large glass wall surfaces, ensuring } \\
\text { compliance with Anti-Terrorism/Force Protection } \\
\text { requirements. }\end{array}$ & \\
\hline
\end{tabular}




\begin{tabular}{|c|c|c|c|}
\hline \multicolumn{4}{|l|}{ Office and Admin Areas } \\
\hline Components Affected & Issue & Requirement & Reference Code \\
\hline Staff Sections & Configuration & $\begin{array}{l}\text { Office sections should be separated by walls or } \\
\text { floors. }\end{array}$ & \\
\hline Private Offices & Configuration & $\begin{array}{l}\text { Private offices should be separated by walls or } \\
\text { floors and should have doors for privacy. }\end{array}$ & \\
\hline Command Offices & Configuration & $\begin{array}{l}\text { Should be built as a more permanent construction } \\
\text { with sound insulation, but still with minimal load } \\
\text { bearing walls so as to accommodate future } \\
\text { reconfiguration. }\end{array}$ & \\
\hline Headquarters & Configuration & $\begin{array}{l}\text { Should be built as a more permanent construction } \\
\text { with sound insulation, but still with minimal load } \\
\text { bearing walls so as to accommodate future } \\
\text { reconfiguration. }\end{array}$ & \\
\hline \multicolumn{4}{|l|}{ Message Center } \\
\hline Components Affected & Issue & Requirement & Reference Code \\
\hline Mail Room & Security & $\begin{array}{l}\text { Provide adequate security for mail storage and } \\
\text { distribution. }\end{array}$ & \\
\hline Doors & Components & $\begin{array}{l}\text { Structural requirements are as follows: Provide } \\
\text { doors with suitable locks and door hinges. }\end{array}$ & \\
\hline Lock & & $\begin{array}{l}\text { Shall be key-operated, mortised, or rim-mounted } \\
\text { lock; have a dead bolt throw one inch; be a double } \\
\text { cylinder design; have five pin tumbler cylinders; } \\
\text { with two of mushroom or spool-type drive pin } \\
\text { design. }\end{array}$ & \\
\hline Windows & Security & Ground-level windows shall have bars. & \\
\hline Windows & Security & $\begin{array}{l}\text { Cover above ground level windows with wire mesh } \\
\text { security screen. }\end{array}$ & \\
\hline Walls & Material & $\begin{array}{l}\text { Shall be made of material to prevent forcible } \\
\text { entry. }\end{array}$ & \\
\hline Ceilings & Material & $\begin{array}{l}\text { Shall be made of material to prevent forcible } \\
\text { entry. }\end{array}$ & \\
\hline Security System & Provided & $\begin{array}{l}\text { Provide provisions for ICIDS (Internal Commercial } \\
\text { Intrusion Detection System) in facilities that are } \\
\text { not operational on a } 24 \text {-hour basis. }\end{array}$ & \\
\hline
\end{tabular}

\section{Secure Documents Room}

Components Affected

Secure Documents

Room
Requirement

Configuration

Located in the S-2 area of building and constructed in accordance with AR 380-5 and classified for Open Storage.
Reference Code

AR 380-5

\section{Network Operations Center}

Components Affected Issue

Requirement

Reference Code

Network Operations

Center

\section{Configuration} secure room in accordance with AR 380-5 and classified for Open Storage
AR 380-5 


\begin{tabular}{|c|c|c|c|}
\hline \multicolumn{4}{|c|}{ Brigade Operations Center } \\
\hline Components Affected & Issue & Requirement & Reference Code \\
\hline $\begin{array}{l}\text { Brigade Operations } \\
\text { Center }\end{array}$ & Configuration & $\begin{array}{l}\text { The BOC will accommodate Gov-Furnished } \\
\text { television screens and monitors. Designed and } \\
\text { constructed as a secure room in accordance with } \\
\text { AR 380-5 and classified for Open Storage. }\end{array}$ & \\
\hline \multicolumn{4}{|c|}{ Sensitive Compartmented Information Facility } \\
\hline Components Affected & Issue & Requirement & Reference Code \\
\hline $\begin{array}{l}\text { Sensitive } \\
\text { Compartmented } \\
\text { Information Facility }\end{array}$ & Configuration & $\begin{array}{l}\text { The SCIF shall be designed and constructed for } \\
\text { accreditation in accordance with DCI Directive 6-9 } \\
\text { and classified for open storage. }\end{array}$ & \\
\hline \multicolumn{4}{|c|}{ Telecommunications Rooms } \\
\hline Components Affected & Issue & Requirement & Reference Code \\
\hline HVAC & Provided & $\begin{array}{l}\text { Served by an independent and dedicated air- } \\
\text { handling system. Air handling system(s) shall not } \\
\text { be floor-space mounted within the actual space } \\
\text { served. }\end{array}$ & \\
\hline Network & Provided & $\begin{array}{l}\text { Space for classified network, unclassified } \\
\text { network, and voice. Space shall be added for } \\
\text { users secure and non-secure telecommunications } \\
\text { equipment such as Private Branch Exchange } \\
\text { (PBX), network switches, routers, servers, and } \\
\text { storage. }\end{array}$ & \\
\hline Room & Size & $\begin{array}{l}\text { Sized and designed in accordance with the 13A } \\
\text { guide and ANSI/EAI/TIA-569-B. Approximate } \\
\text { allocation (total of all rooms) shall be } 2 \text { percent of } \\
\text { the net building area. }\end{array}$ & \\
\hline Room & Location & Locate in a lower level. & \\
\hline Room & Construction & $\begin{array}{l}\text { Plywood backboard ( } 3 / 4 \text { inch thick) around } \\
\text { interior perimeter. }\end{array}$ & \\
\hline Room & Configuration & $\begin{array}{l}\text { Three foot wide door opening out of the room. } \\
\text { [(Brigade Headquarters Only) Dedicated } \\
\text { emergency power panel for all active equipment.] }\end{array}$ & \\
\hline \multirow[t]{2}{*}{ Lighting } & Brightness & 50 foot-candle & \\
\hline & & $\begin{array}{l}\text { Accessed from within the building. No exterior } \\
\text { access shall be provided. }\end{array}$ & \\
\hline Cabinets & Security & $\begin{array}{l}\text { Lockable cabinets shall be provided for security } \\
\text { classification segregation. }\end{array}$ & \\
\hline \multicolumn{4}{|c|}{ Secure Communications Rooms } \\
\hline Components Affected & Issue & Requirement & Reference Code \\
\hline HVAC & Provided & $\begin{array}{l}\text { Served by an independent and dedicated air- } \\
\text { handling system. Air handling system(s) shall not } \\
\text { be floor-space mounted within the actual space } \\
\text { served. }\end{array}$ & \\
\hline Room & Configuration & $\begin{array}{l}\text { Designed and Constructed in accordance with the } \\
\text { Technical Guide for the Integration of Secret } \\
\text { Internet Protocol Router Network. Minimum size } \\
\text { shall be 6'x6' }\end{array}$ & \\
\hline
\end{tabular}


Signal Ground Busbar

SIPRNet

Secure Video

Teleconferencing

JWICS

SIPRNet

Other Site Features

Components Affected

Fire Protection

Sprinkler System

Sprinkler System

Sprinkler Service Main and Riser

Sprinkler Service Main and Riser

Sprinkler Service Main and Riser

Sprinkler Service Main and Riser

Sprinkler Service Main and Riser

Exterior Hose Stream

Backflow Preventer

Backflow Preventer

Backflow Preventer
Present

Present

Issue

Meets Code

Provided

Drainage

Water Supply

Signage

Components

Components

Components

Capacity

Components

Location

Components

Each room shall include a communication signal ground busbar, connected to the main telecom room signal busbar via properly sized ground wire (see MIL-HDBK-419-A) and one dedicated 20-amp circuit for the SIPRNet rack/safe.

Twenty-five percent of all staff in each headquarters shall require Secure Internet Protocol Routing Network (SIPRNet) access, installed in accordance with provisions of Technical Guide for the Integration of SIPRNet.

Secure VTC shall be provided in each Battalion Headquarters Command Conference Room and each Brigade Headquarters Command Conference Room, BOC and SCIF.

Joint Worldwide Intelligence Communications System (JWICS)

Secret Internet Protocol Router Network (SIPRNet)

\section{Requirement}

All fire protection and life safety features shall be in accordance with UFC 3-600-01 and the criteria referenced therein.

The facility shall be fully protected with automatic sprinkler systems. All floors and all areas of the facilities shall be protected. The sprinkler design shall be in accordance with UFC 3-600-01 and NFPA 13

All sprinkler system drains, including main drains, test drains, and auxiliary drains, shall be routed to a 2-foot by 2-foot splash block at exterior grade.

The sprinkler service main shall be a dedicated line from the distribution main. Sprinkler service and domestic service shall not be combined.

The sprinkler service main shall be provided with an exterior post indicator valve with tamper switch reporting to the fire alarm control panel (FACP)

Ground floor entry penetration shall be sleeved per NFPA 13 requirements for seismic protection.

All control valves shall be OS\&Y gate type and shall be provided with tamper switches connected to the FACP.

The floor control valve assembly shall be in accordance with UFC 3-600-01

Exterior hose stream demand shall be in accordance with UFC 3-600-01. This shall be 250 GPM for light hazard and 500 GPM for ordinary hazard.

Double check valve backflow preventer shall be provided on the fire water main serving each building.

Located within the building.

OS\&Y valves and meets NFPA 13 requirements
Reference Code

UFC 3-600-01

UFC 3-600-01, NFPA 13

NFPA 13

UFC 3-600-01

NFPA 13 


\begin{tabular}{|c|c|c|c|}
\hline $\begin{array}{l}\text { Fire Department } \\
\text { Connection }\end{array}$ & Provided & $\begin{array}{l}\text { A fire department connection shall be provided for } \\
\text { each building with sprinkler protection. These } \\
\text { shall be located to be directly accessible to the } \\
\text { fire department. }\end{array}$ & \\
\hline Elevators & Provided & $\begin{array}{l}\text { The fire protection features of elevators, hoist } \\
\text { ways, machine rooms and lobbies shall be in } \\
\text { accordance with UFC 3-600-01, ASME A17.1, } \\
\text { NFPA 13, NFPA } 72\end{array}$ & $\begin{array}{l}\text { UFC 3-600-01, ASME } \\
\text { A17.1, NFPA 13, } \\
\text { NFPA } 72\end{array}$ \\
\hline $\begin{array}{l}\text { Sprinkler System } \\
\text { Hardware }\end{array}$ & Components & $\begin{array}{l}\text { Materials for the sprinkler system, fire pump } \\
\text { system, and hose standpipe system shall be in } \\
\text { accordance with NFPA 13, NFPA } 20\end{array}$ & NFPA 13, NFPA 20 \\
\hline $\begin{array}{l}\text { Earthquake Piping } \\
\text { Protection }\end{array}$ & Components & $\begin{array}{l}\text { Sprinkler and fire pump piping systems shall be } \\
\text { protected against damage from earthquakes. } \\
\text { Flexible and rigid couplings, sway bracing, seismic } \\
\text { separation assemblies at seismic separation } \\
\text { joints as required by NFPA } 13\end{array}$ & NFPA 13 \\
\hline Fire Water Supply & Capacity & Fire test flow data provided in Appendix D & Appendix D \\
\hline Fire Pump & Meets Code & $\begin{array}{l}\text { Comply with requirements of UFC 3-600-01, NFPA } \\
\text { 13, NFPA } 20\end{array}$ & $\begin{array}{l}\text { UFC 3-600-01, NFPA } \\
13 \text {, NFPA } 20\end{array}$ \\
\hline
\end{tabular}




\section{Appendix F: Army Standard Design Criteria for Company Operations Facilities (COF)}

\begin{tabular}{|c|c|c|}
\hline \multicolumn{3}{|l|}{ COF - General } \\
\hline Components Affected & Issue & Requirement \\
\hline & & $\begin{array}{l}\text { Battalion centric design that } \\
\text { consolidates COFs for an entire } \\
\text { battalion in a single building }\end{array}$ \\
\hline & & $\begin{array}{l}\text { Open, flexible design for both admin } \\
\text { and readiness modules, easy to } \\
\text { reconfigure in response to changes } \\
\text { in force structure, equipment and } \\
\text { doctrine }\end{array}$ \\
\hline & Cost Efficient & Economy of construction \\
\hline Site & Location & $\begin{array}{l}\text { Located near the unit motor pool. } \\
\text { Should be located within walking } \\
\text { distance of unit admin and barracks. }\end{array}$ \\
\hline Fire Protection & Design & Meets Code \\
\hline Audio/Visual & Provided & $\begin{array}{l}\text { Provisions for a Government- } \\
\text { furnished Government-installed } \\
\text { projector shall be provided in each } \\
\text { conference room. }\end{array}$ \\
\hline Backflow Preventer & Availability & $\begin{array}{l}\text { A double check backflow preventer } \\
\text { shall be provided on the fire water } \\
\text { main serving each building. This } \\
\text { shall be located within the building. } \\
\text { An exterior wall hydrant with dual } \\
\text { hose connections with OS\&Y valve } \\
\text { shall be provided to allow testing of } \\
\text { backflow preventer at design at } \\
\text { design flow as required by NFPA } 13 \text {. }\end{array}$ \\
\hline Design & Security Threat & $\begin{array}{l}\text { Constructed to meet requirements of } \\
\text { a Risk Level II analysis in accordance } \\
\text { with AR 190-51 and AR 190-13 }\end{array}$ \\
\hline $\begin{array}{l}\text { Domestic Hot Water } \\
\text { Supply }\end{array}$ & & $\begin{array}{l}\text { The main water heating equipment } \\
\text { shall be located within a mechanical } \\
\text { room, and also located on the } \\
\text { ground floor level only. No } \\
\text { Instantaneous water heaters except } \\
\text { for Readiness Area. }\end{array}$ \\
\hline Electrical System & Adequate & $\begin{array}{l}\text { Power system provides a safe, } \\
\text { efficient, and economical distribution } \\
\text { of power, based upon the size and } \\
\text { types of loads to be served. }\end{array}$ \\
\hline
\end{tabular}

Reference Code

NFPA 13

AR 190-51 and AR 190-13 


\begin{tabular}{|c|c|c|c|}
\hline Electrical System & $\begin{array}{l}\text { Grounded } \\
\text { Properly }\end{array}$ & $\begin{array}{l}\text { The ground counterpoise shall be } \\
\text { provided around the building } \\
\text { perimeter and shall be utilized for } \\
\text { grounding incoming service, building } \\
\text { steel, telephone service, piping, } \\
\text { lightning protection, and internal } \\
\text { grounding requirements. }\end{array}$ & $\begin{array}{l}\text { NFPA } 70 \text { National Electrical Code, } \\
\text { NFPA } 780 \text { Lightning Protection } \\
\text { Code, local codes, US Army 13A } \\
\text { Guide }\end{array}$ \\
\hline Exterior Hose Stream & Capacity & $\begin{array}{l}250 \text { gpm for light hazard and } 500 \\
\text { gpm for ordinary hazard }\end{array}$ & \\
\hline Exterior Wall & Material & $\begin{array}{l}\text { Consisting of } 26 \text { gauge metal wall } \\
\text { panels with insulation and interior } \\
\text { metal liner panel extended to a } \\
\text { height of } 8 \text { ' above the finished floor. }\end{array}$ & AR 190-51, Appendix B \\
\hline Exterior Wall Hydrants & Availability & $\begin{array}{l}\text { One additional freeze-proof exterior } \\
\text { wall hydrant of wall faucet per } \\
\text { company shall be provided at the } \\
\text { hardstand }\end{array}$ & \\
\hline Floor Plan & Size & $\begin{array}{l}\text { Increased interior space - } 40 \text { SF } \\
\text { layout areas for } 50 \% \text { of intended } \\
\text { personnel }\end{array}$ & \\
\hline Fire Alarm & Provided & $\begin{array}{l}\text { Complies with UFC 3-600-01 and } \\
\text { NFPA 72. Integrated with local } \\
\text { Installation wide Fire Alarm System }\end{array}$ & UFC 3-600-01 and NFPA 72 \\
\hline Fire Alarm & Connected & $\begin{array}{l}\text { All initiating devices shall be } \\
\text { connected, Class A, Style } 6 \text {, to signal } \\
\text { line circuits (SLC). Alarm appliances } \\
\text { shall be connected to notification } \\
\text { appliance circuits (NAC), Class A. A } \\
\text { looped conduit system shall be } \\
\text { provided so that if the conduit and all } \\
\text { conductors within are severed at any } \\
\text { point, all NAC and SLC shall remain } \\
\text { functional. }\end{array}$ & \\
\hline Fire Alarm & & $\begin{array}{l}\text { Break glass manual fire alarm } \\
\text { stations shall not be used. }\end{array}$ & \\
\hline Fire Alarm & Electric Power & $\begin{array}{l}\text { Over-voltage and surge protection } \\
\text { shall be provided at the input power } \\
\text { of all panels. }\end{array}$ & \\
\hline Fire Protection & Design & Meets specified code & UFC 3-600-01 and NFPA 13 \\
\hline Fire Protection & Drainage & $\begin{array}{l}\text { All drains lead to a } 2^{\prime} \times 2 \text { ' splash } \\
\text { block }\end{array}$ & \\
\hline Fire Protection & Components & $\begin{array}{l}\text { Main and Riser are separate from } \\
\text { domestic water lines }\end{array}$ & \\
\hline Fire Protection & Components & $\begin{array}{l}\text { Ground floor entry penetration shall } \\
\text { be sleeved per NFPA } 13 \\
\text { requirements for seismic protection. }\end{array}$ & \\
\hline Fire Protection & Connectivity & $\begin{array}{l}\text { A fire department connection shall } \\
\text { be provided for each building with } \\
\text { sprinkler protection. These shall be } \\
\text { located to be directly accessible to } \\
\text { the fire department. }\end{array}$ & \\
\hline
\end{tabular}


Fire Protection

Fire Water Supply $\quad$ Flow

Interior Lighting Meets Code

Interior Wall

Lighting

Lighting Controls

$\begin{array}{ll}\text { Lightning Protection } & \text { Safe } \\ \text { Lockers } & \text { Material } \\ \text { Lockers } & \text { Signage } \\ \text { Lockers } & \text { Components } \\ \text { Lockers } & \text { Mounting } \\ \text { Lockers } & \text { Paint }\end{array}$

Material

Adequatly lit

Light Quality
Materials for the sprinkler system, fire pump system, and hose standpipe system shall be in accordance with NFPA 13 and NFPA 20

Dependent on the flow test data from the project site and fire protection system design requirements for the project.

Fire flow test is provided in Appendix D

Interior Lighting. Interior ambient illumination shall provide a generally glare free, high quality lighting environment and conform to IESNA RP-1-04

Contracted for devising walls between company readiness areas shall consist of a stud wall with impact resistant gypsum wall board each side

Lighting and lighting controls shall comply with the recommendations of the Illumination Engineering Society of North America (IESNA) and the requirements of ASHRAE 90.1

Local manual controls supplement automatic controls in offices and specialized such as conference rooms. Occupancy sensor controls shall be provided in restrooms, electrical rooms, telecommunications rooms and similar spaces. Interior ambient light provides a glare free, high quality lighting environment and conform to IESNA RP-1-04

Lightning protection system is in accordance with NFPA 780 and other referenced criteria.

16 gauge thick cold sheet steel; 1 " $x$ $1 " x$ 1/8" angle iron frames

Aluminum number plate (numbered in sequential order)

Full width shelf located 12" from the top with clothes hangar rod and three locker hooks mounted below

Mounted to concrete floor per manufacturer's guidelines

Covered with high quality durable finish with color to be manufacturer's standard tan or grey
NFPA 13 and NFPA 20

UFC 3-600-01, NFPA 13, and NFPA 20

Appendix D

ASHRAE 90.1

IESNA RP-1-04 


\begin{tabular}{|c|c|c|}
\hline Lockers & Size & $\begin{array}{l}\text { Enlarged TA-50 lockers } 42 "(\mathrm{w}) \mathrm{x} \\
24 "(\mathrm{~d}) \times 78 \text { ( }(\mathrm{h}) \text { for } 100 \% \text { of intended } \\
\text { personnel in each company }\end{array}$ \\
\hline Network Connection & Provided & $\begin{array}{l}\text { All COF workstations have voice and } \\
\text { data connection capability. All } \\
\text { conference rooms have voice and } \\
\text { data connection capability. }\end{array}$ \\
\hline Receptacles & Adequate & $\begin{array}{l}\text { Receptacles provided per NFPA } 70 \\
\text { and in conjunction with the proposed } \\
\text { equipment and furniture layouts. } \\
\text { Power connectivity to each } \\
\text { workstation. Power poles shall not be } \\
\text { used. Provide duplex receptacles } \\
\text { adjacent to each duplex (voice/data) } \\
\text { outlet and CATV outlet. }\end{array}$ \\
\hline Riser & Components & $\begin{array}{l}\text { Equipped with a double backflow } \\
\text { preventer and control valve. Facilities } \\
\text { with multiple floors should have } \\
\text { control valve at each floor. }\end{array}$ \\
\hline Showers & & $\begin{array}{l}\text { Consolidated showers for combined } \\
\text { building occupancy }\end{array}$ \\
\hline Sprinklers/Fire Pump & $\begin{array}{l}\text { Earth quake } \\
\text { resilient }\end{array}$ & $\begin{array}{l}\text { Mounted with flexible and rigid } \\
\text { couplings, sway bracing, seismic } \\
\text { separation assemblies where piping } \\
\text { crosses building seismic separation } \\
\text { joints, and other features as required } \\
\text { by NFPA } 13 .\end{array}$ \\
\hline $\begin{array}{l}\text { Telecommunications } \\
\text { Rooms }\end{array}$ & Provided & $\begin{array}{l}\text { Minimum of one room per floor, } \\
\text { located as near the center of the } \\
\text { building as practicable, and stacked } \\
\text { between floors. The } \\
\text { telecommunications rooms shall be } \\
\text { designed in accordance with the 13A } \\
\text { Guide and ANSI/EIA/TIA-569-B }\end{array}$ \\
\hline Water Heater Storage & Size & Minimum of $600 \mathrm{GAL}$ \\
\hline
\end{tabular}

NFPA 70

UFC 3-600-01, Figure 4-1

NFPA 13

13A Guide and ANSI/EIA/TIA-569-

$B$

Tank

\section{COF - Fire Extinguisher Cabinets and Brackets}

\section{Components Affected}

Fire Extinguisher

Issue

Requirement

Mounting

Cabinets and Brackets
Semi-recessed cabinets shall be provided in finished areas and brackets shall be provided in nonfinished areas.

\section{Reference Code}

UFC 3-600-01 and NFPA 10 and NFPA 101

\section{COF - Interior Wall and Ceiling Finishes Components Affected \\ Issue}

Interior Wall and

Ceiling Finishes
Requirement

Interior wall and ceiling finishes and movable partitions shall conform to the requirements of UFC 3-600-01 and NFPA 101

\section{COF - Administrative \\ Components Affected}

Window

Window

\section{Issue}

Lighting

Ventilation

\section{Requirement}

\section{Reference Code}

Reference Code

UFC 3-600-01 and NFPA 101

Natural Lighting provided

Natural ventilation is available 


\begin{tabular}{|c|c|c|c|}
\hline Insulation & Sound & $\begin{array}{l}\text { STC } 42 \text { at walls and floor/ceiling } \\
\text { assemblies, and STC } 33 \text { rating for } \\
\text { doors }\end{array}$ & \\
\hline Conference Area & Sound & Noise Criteria (NC) 30 rating & ASHRAE \\
\hline Doors & Material & Solid core wood in a metal frame. & \\
\hline Floor Plan & Configuration & $\begin{array}{l}\text { Flexibility for future rearrangement } \\
\text { within office and admin areas }\end{array}$ & \\
\hline Command Offices & Sound & $\begin{array}{l}\text { STC } 42 \text { at walls and floor/ceiling } \\
\text { assemblies, and STC } 33 \text { rating for } \\
\text { doors }\end{array}$ & \\
\hline Walls & Structure & $\begin{array}{l}\text { Non-load bearing walls for } \\
\text { reconfiguration in future }\end{array}$ & \\
\hline \multirow[t]{2}{*}{ HVAC } & & $\begin{array}{l}\text { Shall be temperature-controlled by } \\
\text { the DDC system. Temperature set } \\
\text { point adjustment shall be } \\
\text { accomplished via DDC System by } \\
\text { authorized personnel }\end{array}$ & \\
\hline & Construction & $\begin{array}{l}\text { Constructed in accordance with } \\
\text { Technical Guide for the Integration of } \\
\text { Secret Internet Protocol Router } \\
\text { Network (SIPRNet) }\end{array}$ & \\
\hline Electrical & & $\begin{array}{l}\text { Provide one dedicated } 20 \text {-amp } \\
\text { breaker for the SIPRNet rack/safe, in } \\
\text { addition to convenience outlets in } \\
\text { the SIPRNet room. }\end{array}$ & \\
\hline
\end{tabular}

\begin{tabular}{|c|c|c|c|}
\hline \multicolumn{4}{|c|}{ COF - Administrative - Private Offices for the Commander, First Sergeant, Exec } \\
\hline \multirow[t]{2}{*}{ Components Affected } & Issue & Requirement & Reference Code \\
\hline & Configuration & $\begin{array}{l}\text { Private offices for the Commander, } \\
\text { First Sergeant, Executive Officer and } \\
\text { Training Room }\end{array}$ & \\
\hline \multicolumn{4}{|c|}{ COF - Administrative - Printer Area } \\
\hline \multirow[t]{2}{*}{ Components Affected } & Issue & Requirement & Reference Code \\
\hline & Configuration & $\begin{array}{l}\text { Space for printer and fax machines, } \\
\text { waste and paper recycling } \\
\text { receptacles, and supply closet for } \\
\text { storage }\end{array}$ & \\
\hline
\end{tabular}

COF - Administrative - Shared Office Space
Components Affected Issue

Configuration

COF - Administrative - Conference

Components Affected Issue

Configuration

Requirement

Reference Code

Shared Office space for platoon

leaders and platoon sergeants

Requirement

Reference Code

Conference space for meetings and/or training

$\begin{array}{lll}\text { COF - Administrative - Shower Area } & \\ \text { Components Affected } & \text { Issue } & \text { Requirement } \\ \text { Plumbing } & \begin{array}{l}\text { Plumbing } \\ \text { Service }\end{array} & \begin{array}{l}\text { A place for commuters to shower and } \\ \text { change after PT }\end{array}\end{array}$

COF - Administrative - Shower Area

Reference Code 


\begin{tabular}{|c|c|c|c|}
\hline \multicolumn{4}{|c|}{ COF - Administrative - Consolidate Utility Areas } \\
\hline Components Affected & Issue & Requirement & Reference Code \\
\hline \multicolumn{4}{|l|}{ Utility Areas } \\
\hline \multicolumn{4}{|c|}{ COF - Administrative - Communications SIPRNet Rooms } \\
\hline Components Affected & Issue & Requirement & Reference Code \\
\hline HVAC & $\begin{array}{l}\text { Air handling } \\
\text { unit }\end{array}$ & $\begin{array}{l}\text { Served by an independent and } \\
\text { dedicated air-handling system. Shall } \\
\text { not be floor space mounted within } \\
\text { the actual space reserved. Rooms } \\
\text { shall maintain } 72 \text { degrees F and } 50 \\
\text { relative humidity year-round. Assume } \\
1775 \text { BTU per hour for equipment } \\
\text { heat dissipation. }\end{array}$ & \\
\hline Cable Television & Adequate & $\begin{array}{l}\text { Cable system consists of cabling, } \\
\text { pathways, and outlets. Meets } \\
\text { applicable criteria. }\end{array}$ & UFC 3-580-01 \\
\hline Intrusion Detection & Components & $\begin{array}{l}\text { Contractor shall install the necessary } \\
\text { conduit, electrical power, and wiring, } \\
\text { to support installation of an ICIDS } \\
\text { system in each of the Arms Room } \\
\text { and SIPRNet Room. The Government } \\
\text { shall install the signal devices and } \\
\text { equipment necessary to activate the } \\
\text { system }\end{array}$ & \\
\hline Audio/Visual System & Components & $\begin{array}{l}\text { Provisions (consisting of a power } \\
\text { receptacle and conduit for signal } \\
\text { wiring) for a Government-furnished } \\
\text { Government-installed projector shall } \\
\text { be provided in each conference } \\
\text { room. }\end{array}$ & \\
\hline Intercom & Provided & $\begin{array}{l}\text { Mass notification system provided. } \\
\text { Including; speakers, strobes, cabling, } \\
\text { pathways, activator stations, and a } \\
\text { main console/amplifier utilizing a } \\
\text { telephone and wireless input for } \\
\text { local facility wide instruction shall be } \\
\text { provided to provide coverage } \\
\text { throughout facility. }\end{array}$ & UFC 4-010-01 \\
\hline \multicolumn{4}{|l|}{ COF - Readiness Module } \\
\hline Components Affected & Issue & Requirement & Reference Code \\
\hline Structure & Code & Built to code specs. & AR 190-51 \& AR 190-13 \\
\hline Exterior Wall & Material & $\begin{array}{l}\text { Consists of } 26 \text { gauge metal wall } \\
\text { panels with insulation and an interior } \\
\text { metal liner panel extended to a } \\
\text { height of } 8 \text { ' above the finished floor } \\
\text { will satisfy the minimum Risk Level II } \\
\text { requirements }\end{array}$ & $\begin{array}{l}\text { AR 190-51, Appendix B-2, } \\
\text { paragraph c }\end{array}$ \\
\hline Interior Wall & Material & $\begin{array}{l}\text { Consist of a stud wall with impact } \\
\text { resistant gypsum wall board each } \\
\text { side }\end{array}$ & \\
\hline Windows & Secure & Locks & \\
\hline Walls & Structure & $\begin{array}{l}\text { Non-load bearing walls for } \\
\text { reconfiguration in future }\end{array}$ & \\
\hline
\end{tabular}




\author{
HVAC \\ Future Soldier LAN \\ Warrior System
}

Ventilated adequately
Arms Vault

Security Storage

Availability
Should be heated and air conditioned. Indoor design temperature for heating shall be 55 degrees $F$, and cooling shall be 80 degrees $F$ with maximum 60 percent humidity.

Provide an empty 3-inch conduit (with pull wire and capped) from the main distribution panel to a location in this room for a future power panel and an empty 2 -inch conduit (with pull wire and capped) from the main telephone backboard to a location in this room for the future data connection system.

Enlarged arms vaults - option of prefabricated/modular vaults

Provision for non-sensitive items secure storage

\section{COF - Readiness Module - Readiness Bays Components Affected Issue Configuration}

\begin{abstract}
Maintenance Area
\end{abstract}
Size

Forklift

Access

Sinks

Provided

Sinks

Occurrence

\section{COF - Readiness Module - Supply Bays}

\section{Requirement}

\section{Provide accommodation for} individual combat equipment lockers for all unit personnel, plus co-located area for equipment maintenance, training, and pre-deployment preparations.

Big enough for $50 \%$ of unit personnel to have a 5' x 8' space to layout TA50 gear

Floor should support forklift movement throughout area.

Interior mud wash utility sink shall be provided in Readiness areas.

\section{Reference Code}

$\begin{array}{ccl}\text { Configuration } & \begin{array}{l}\text { Provide storage space for company } \\ \text { supplies and equipment: weapons } \\ \text { and consumable supplies }\end{array} \\ \text { Configuration } & \begin{array}{l}\text { Provides accommodation for supply } \\ \text { sergeant, supply clerks, and the } \\ \text { armorer in performing sipping and } \\ \text { receiving functions }\end{array} \\ \text { Components Affected } \quad \text { Issue } & \text { Security } & \begin{array}{l}\text { Requirement } \\ \text { Cecure storage room for non- } \\ \text { sensitive items }\end{array} \\ & \text { Configuration } & \begin{array}{l}\text { Nuclear, biological, and chemical } \\ \text { (NBC) equipment storage } \\ \text { Communications equipment storage }\end{array}\end{array}$

Requirement Reference Code

\section{Reference Code}




\begin{tabular}{|c|c|c|c|}
\hline \multirow{2}{*}{ Intrusion Detection } & \multirow{2}{*}{$\begin{array}{l}\text { Configuration } \\
\text { Security }\end{array}$} & \multicolumn{2}{|l|}{ Consumable unit storage } \\
\hline & & \multicolumn{2}{|l|}{$\begin{array}{l}\text { Contractor shall install the necessary } \\
\text { conduit, electrical power, and wiring, } \\
\text { to support installation of an ICIDS } \\
\text { system in each of the Arms Rooms. }\end{array}$} \\
\hline \multicolumn{4}{|c|}{ COF - Readiness Module - Overflow } \\
\hline Components Affected & Issue & Requirement & Reference Code \\
\hline Mezzanine & & $\begin{array}{l}\text { Utilization of mezzanine for } \\
\text { overflow/expansion storage within } \\
\text { the area limitations }\end{array}$ & IBC NFPA 101 \\
\hline \multicolumn{4}{|c|}{ COF - Site - Exterior Covered Hardstand } \\
\hline Components Affected & Issue & Requirement & Reference Code \\
\hline & Size & Varying & Paragraph 2.0 SCOPE \\
\hline \multirow[t]{2}{*}{ Canopy } & Size & $\begin{array}{l}\text { Minimum height of } 14 \text { ' or such } \\
\text { height as required to allow for } \\
\text { operational truck access. Minimum } \\
\text { clear depth is } 30^{\prime}\end{array}$ & \\
\hline & Location & Adjacent to the readiness module. & \\
\hline Electrical & Outlets & $\begin{array}{l}\text { Provide weatherproof lighting and } \\
\text { weatherproof general purposes } \\
\text { receptacles with GFCl. One duplex } \\
\text { receptacle for every two columns }\end{array}$ & \\
\hline Ext Maintenance Areas & Size & $\begin{array}{l}\text { Covered exterior maintenance areas } \\
\text { - } 40 \text { SF for } 25 \% \text { of intended } \\
\text { personnel }\end{array}$ & \\
\hline
\end{tabular}

\section{COF - Site - Service Yard}

Components Affected Issue

Pavement

Size

Drainage

Slope

Components

Components

\section{Requirement}

Reference Code

Rigid Concrete

Deep enough for a 35-foot long vehicle with 45-foot turning radius along entire Readiness Module.

Sloped to drain away from Readiness Facility

Provide one boot/TA-50 gear washing station per company.

Each station shall include four freeze proof hose bibb and drying rack (handrail)

\begin{tabular}{|c|c|c|}
\hline $\begin{array}{l}\text { COF - Site - Entrance } \\
\text { Components Affected }\end{array}$ & Issue & Requirement \\
\hline Entrance Pavement & Size & Entrance is 28 -foot wide \\
\hline Entrance Pavement & Location & $\begin{array}{l}\text { Entrances are on opposite sides of } \\
\text { the service yard }\end{array}$ \\
\hline \multicolumn{3}{|l|}{ COF - Site - Bollards } \\
\hline Components Affected & Issue & Requirement \\
\hline Bollards & Size & 6 -inch diameter by 5 -foot high \\
\hline Bollards & & schedule 80 galvanized steel pipe \\
\hline
\end{tabular}

Reference Code

Reference Code

6-inch diameter by 5-foot high

galvanized steel pipe 
Bollards Configuration 5-foot O.C. spacing, 5-feet from edge of electrical and mechanical equipment

Bollards Paint Painted safety yellow

COF - Site - Privately Owned Parking

Components Affected Issue

POV Parking

Size
Requirement

Reference Code

One space for every two people for the maximum design capacity of all COF 


\section{Appendix G: Army Standard Design Criteria for Tactical Equipment Maintenance Facilities (TEMF)}

\begin{tabular}{|c|c|c|c|}
\hline \multicolumn{4}{|c|}{ Repair and Maintenance Areas - General } \\
\hline $\begin{array}{l}\text { Components } \\
\text { Affected }\end{array}$ & Issue & Requirement & $\begin{array}{l}\text { Reference } \\
\text { Code }\end{array}$ \\
\hline $\mathrm{N} / \mathrm{A}$ & Size & $32 ' x 96 '$ & \\
\hline Structure & $\begin{array}{l}\text { Interior } \\
\text { Columns }\end{array}$ & None in Structural Bays & \\
\hline Structure & $\begin{array}{l}\text { Ceiling } \\
\text { Height }\end{array}$ & Min $20^{\prime}$ to crane hook cradle & \\
\hline Concrete Floor & Slope & & $\begin{array}{l}\text { NFPA 30A, } \\
\text { IBC/IPC }\end{array}$ \\
\hline $\begin{array}{l}\text { Internal Partition } \\
\text { Walls }\end{array}$ & Type & Fixed walls adjacent to core areas & \\
\hline Trench Drains & Location & $\begin{array}{l}\text { Outside wall near doors, centerline of central } \\
\text { corridor }\end{array}$ & \\
\hline Trench Drains & Size & 6" & \\
\hline Overhead doors & Size & 24' wide $\times 14$ ' 8" wide & \\
\hline Overhead doors & Type & Coiling, (or sectional, telescopic), heavy duty & \\
\hline Overhead doors & Location & Each end of structural bay & \\
\hline Overhead doors & Operation & $\begin{array}{l}\text { Electric w/Manual chain, interior operation only, } \\
\text { intermediate stop, locking }\end{array}$ & \\
\hline Overhead doors & Optional & Insulated and vision panel & \\
\hline Bollards & Size & 12" dia, 5' height & \\
\hline Bollards & Type & Concrete filled steel & \\
\hline Bollards & Location & Each side of all $\mathrm{OH}$ Door Openings & \\
\hline Personnel Doors & Size & $3^{\prime} \times 7^{\prime}$ & \\
\hline Personnel Doors & Type & Steel, vision panel & \\
\hline Personnel Doors & Location & each end maintenance area & \\
\hline Windows/Skylights & Day lighting & $\begin{array}{l}\text { Skylights, clerestory windows, translucent panel } \\
\text { preferred }\end{array}$ & \\
\hline Heat Plant & $\begin{array}{l}\text { Temperatur } \\
\text { e }\end{array}$ & $55 \operatorname{deg} F$ & \\
\hline Supply Fan & IAQ & $\begin{array}{l}100 \% \text { out door air (no re-circ, no return air } \\
\text { plenum) }\end{array}$ & \\
\hline Supply Fan & Operation & VFD, CO and NOX sensor & \\
\hline Supply Fan & Capacity & 1.5 SFM per SF & \\
\hline Exhaust & Operation & Continuous & \\
\hline Exhaust & Optional & ERV & \\
\hline Lighting & $\begin{array}{l}\text { illumination } \\
\text { level }\end{array}$ & $50 \mathrm{FC}$ & \\
\hline
\end{tabular}




\begin{tabular}{|c|c|c|c|}
\hline Lighting & Type & T5, T5H0, or T8 Fluorescent & \\
\hline Lighting & Type & $\begin{array}{l}\text { Optional use of hybrid lighting and light tubes ( } 3 \mathrm{M} \\
\text { light pipe) }\end{array}$ & \\
\hline Paging System & Location & All structural repair bays & \\
\hline \multicolumn{4}{|c|}{ Repair and Maintenance Areas - Repair } \\
\hline $\begin{array}{l}\text { Components } \\
\text { Affected }\end{array}$ & Issue & Requirement & $\begin{array}{l}\text { Reference } \\
\text { Code }\end{array}$ \\
\hline N/A & Size & $\begin{array}{l}\text { Structural height shall be as required to allow } \\
\text { minimum bridge crane hook cradle height of } 20 \\
\text { feet }\end{array}$ & $\begin{array}{l}\text { CMMA } 70 \\
\text { or CMAA } 74\end{array}$ \\
\hline Crane & Location & Coverage for all structural bays & \\
\hline Crane & Capacity & $10 \mathrm{TN}, 35 \mathrm{TN}$ & $\begin{array}{l}\text { ASME HST- } \\
1 \text { or HST-4 }\end{array}$ \\
\hline Crane & Operation & $\begin{array}{l}10 \mathrm{TN} \text { - hoist } 20 \mathrm{fpm} \text {, trolley } 65 \mathrm{fpm} \text {, bridge } 125 \\
\text { fpm (each direction) }\end{array}$ & \\
\hline Crane & Operation & $\begin{array}{l}35 \mathrm{TN} \text { - hoist } 10 \mathrm{fpm} \text {, trolley } 60 \mathrm{fpm} \text {, bridge } 85 \\
\text { fpm (each direction) }\end{array}$ & \\
\hline Compressed Air & Location & 2 outlets, each pr of repair areas, 3' above floor & \\
\hline Compressed Air & Type & quick disconnect couplings, 120 psi & \\
\hline Electric Power & Location & each pair of repair areas, for hydraulic lifts & \\
\hline Data connection & Location & NIPR/SIPRNet connection in each repair area & \\
\hline Vehicle Exhaust & Type & $\begin{array}{l}1400 \mathrm{cfm}, 700 \mathrm{Deg} F \text {, or } 1200 \mathrm{~F} \text { for tracked } \\
\text { vehicles }\end{array}$ & \\
\hline \multicolumn{4}{|c|}{ Repair and Maintenance Areas - Repair - Tire Changing } \\
\hline $\begin{array}{l}\text { Components } \\
\text { Affected }\end{array}$ & Issue & Requirement & $\begin{array}{l}\text { Reference } \\
\text { Code }\end{array}$ \\
\hline N/A & Location & $\begin{array}{l}\text { Provide capability for tire changing function within } \\
\text { one pair of repair areas }\end{array}$ & \\
\hline \multicolumn{4}{|c|}{ Repair and Maintenance Areas - Repair - Wash Bay } \\
\hline $\begin{array}{l}\text { Components } \\
\text { Affected }\end{array}$ & Issue & Requirement & $\begin{array}{l}\text { Reference } \\
\text { Code }\end{array}$ \\
\hline N/A & Location & one in repair area of each wing & \\
\hline Wall & Type & 5'4" high CMU separation wall & \\
\hline \multicolumn{4}{|c|}{ Repair and Maintenance Areas - Repair - Welding Area } \\
\hline $\begin{array}{l}\text { Components } \\
\text { Affected }\end{array}$ & Issue & Requirement & $\begin{array}{l}\text { Reference } \\
\text { Code }\end{array}$ \\
\hline Exhaust & Type & Non-sparking, manual engagement & \\
\hline $\mathrm{N} / \mathrm{A}$ & Location & One per pair of repair areas & \\
\hline Trench Drain & Cover & Solid Cover & \\
\hline \multicolumn{4}{|c|}{ Repair and Maintenance Areas - Maintenance Area } \\
\hline $\begin{array}{l}\text { Components } \\
\text { Affected }\end{array}$ & Issue & Requirement & $\begin{array}{l}\text { Reference } \\
\text { Code }\end{array}$ \\
\hline POL Hose Reels & & $2 x$, wall mounted & \\
\hline POL Hose Reels & $\begin{array}{l}\text { Component } \\
\mathrm{s}\end{array}$ & $\begin{array}{l}\text { Provides shut off valve, distribution for } \\
\text { grease/engine oil/gear oil/transmission } \\
\text { fluid/antifreeze }\end{array}$ & \\
\hline POL Hose Reels & Structure & Heavy duty construction & \\
\hline
\end{tabular}




\begin{tabular}{|c|c|c|c|}
\hline \multicolumn{4}{|c|}{ Repair and Maintenance Areas - Maintenance Area - Maintenance Pit } \\
\hline $\begin{array}{l}\text { Components } \\
\text { Affected }\end{array}$ & Issue & Requirement & $\begin{array}{l}\text { Reference } \\
\text { Code }\end{array}$ \\
\hline N/A & Size & 40'x3'6"x4'4" deep & \\
\hline Lighting & $\begin{array}{l}\text { illumination } \\
\text { level }\end{array}$ & $15 \mathrm{FC}$ & \\
\hline Lighting & Type & T5, T5H0, or T8 Fluorescent & \\
\hline Sump & Present & Yes & \\
\hline Compressed Air & Location & $2 x$ outlets & \\
\hline Floor & Type & Non-slip floor grating & \\
\hline Exhaust & Type & Ducted, with explosion proof fan & \\
\hline Pit Cover & Size & $\begin{array}{l}\text { Manageable by maximum of two people, and } \\
\text { support pedestrian traffic }\end{array}$ & \\
\hline
\end{tabular}

\begin{tabular}{|c|c|c|c|}
\hline \multicolumn{4}{|c|}{ Repair and Maintenance Areas - Circulation Bays } \\
\hline $\begin{array}{l}\text { Components } \\
\text { Affected }\end{array}$ & Issue & Requirement & $\begin{array}{l}\text { Reference } \\
\text { Code }\end{array}$ \\
\hline $\mathrm{N} / \mathrm{A}$ & Size & $8^{\prime} \times 966^{\prime}$ & \\
\hline $\mathrm{N} / \mathrm{A}$ & Location & between each wing and core areas & \\
\hline $\mathrm{N} / \mathrm{A}$ & Egress & & OSHA \\
\hline Emergency eyewash & Location & One per bay & $\begin{array}{l}\text { OSHA } \\
\text { 1910.151( } \\
\text { c), ANSI } \\
\text { Z358 }\end{array}$ \\
\hline Emergency shower & Location & One per bay & $\begin{array}{l}\text { OSHA } \\
\text { 1910.151( } \\
\text { c), ANSI } \\
\text { Z358 }\end{array}$ \\
\hline $\begin{array}{l}\text { Emergency hand } \\
\text { held drench hose }\end{array}$ & Location & One per bay & $\begin{array}{l}\text { OSHA } \\
\text { 1910.151( } \\
\text { c), ANSI } \\
\text { Z358 }\end{array}$ \\
\hline Personnel Doors & Size & $3^{\prime} \times 7^{\prime}$ & \\
\hline Personnel Doors & Type & Steel, vision panel & \\
\hline \multicolumn{4}{|l|}{ Core Areas } \\
\hline $\begin{array}{l}\text { Components } \\
\text { Affected }\end{array}$ & Issue & Requirement & $\begin{array}{l}\text { Reference } \\
\text { Code }\end{array}$ \\
\hline $\mathrm{N} / \mathrm{A}$ & Layout & 1 or 2 story & \\
\hline N/A & $\begin{array}{l}\text { Accessibilit } \\
y\end{array}$ & ABA compliant & ABA \\
\hline $\begin{array}{l}\text { Internal Partition } \\
\text { Walls }\end{array}$ & Type & Non-Load Bearing (reconfigurable) & \\
\hline Lighting & Controls & Day lighting & \\
\hline Heat Plant & & & $\begin{array}{l}\text { Para 5, sec } \\
011100\end{array}$ \\
\hline Telecom & Outlets & One per work area/workstation & \\
\hline $\begin{array}{l}\text { Fire Extinguisher } \\
\text { Cabinets }\end{array}$ & Location & & \\
\hline
\end{tabular}




\begin{tabular}{|c|c|c|c|}
\hline \multicolumn{4}{|c|}{ Core Areas - Admin and Shop Control } \\
\hline $\begin{array}{l}\text { Components } \\
\text { Affected }\end{array}$ & Issue & Requirement & $\begin{array}{l}\text { Reference } \\
\text { Code }\end{array}$ \\
\hline Reception window & Location & Counter to Corridor & \\
\hline Reception window & Type & Lockable, coiling shutter & \\
\hline Reception window & Size & $30 " x 30 "$ & \\
\hline Interior Windows & Type & Fixed & \\
\hline Exterior Windows & Type & Operable & \\
\hline Lighting & $\begin{array}{l}\text { illumination } \\
\text { level }\end{array}$ & $50 \mathrm{FC}$ & \\
\hline Data & Outlets & Voice/Data at each workstation & \\
\hline CATV & Outlets & $2 x$ & \\
\hline Paging System & Location & Microphone & \\
\hline \multicolumn{4}{|c|}{ Core Areas - Training Room } \\
\hline $\begin{array}{l}\text { Components } \\
\text { Affected }\end{array}$ & Issue & Requirement & $\begin{array}{l}\text { Reference } \\
\text { Code }\end{array}$ \\
\hline N/A & Size & accommodate 30 students & \\
\hline Walls & Sound & STC $>45$ & \\
\hline Electric Power & Location & Each student & \\
\hline Data connection & Location & Each student & \\
\hline Exterior Windows & Type & Operable & \\
\hline Lighting & Type & Glare free, dimmable ballast & \\
\hline \multicolumn{4}{|c|}{ Core Areas - Consolidated Bench } \\
\hline $\begin{array}{l}\text { Components } \\
\text { Affected }\end{array}$ & Issue & Requirement & $\begin{array}{l}\text { Reference } \\
\text { Code }\end{array}$ \\
\hline $\mathrm{N} / \mathrm{A}$ & Size & $16 \mathrm{SF}$ & \\
\hline Walls & Sound & $\mathrm{STC}>45$ & \\
\hline Overhead doors & Size & $10 ' \times 10^{\prime}$ & \\
\hline Overhead doors & Type & Coiling, (or sectional, telescopic), heavy duty & \\
\hline Overhead doors & Location & One & \\
\hline Overhead doors & Operation & $\begin{array}{l}\text { Electric w/Manual chain, interior operation only, } \\
\text { locking }\end{array}$ & \\
\hline Overhead doors & Optional & Insulated & \\
\hline Exterior Windows & Type & Operable & \\
\hline Personnel Doors & Location & To Circulation Bay & \\
\hline Personnel Doors & Type & Lockable & \\
\hline Compressed Air & Location & outlets in room & \\
\hline \multicolumn{4}{|c|}{ Core Areas - Tools Room } \\
\hline $\begin{array}{l}\text { Components } \\
\text { Affected }\end{array}$ & Issue & Requirement & $\begin{array}{l}\text { Reference } \\
\text { Code }\end{array}$ \\
\hline $\mathrm{N} / \mathrm{A}$ & $\begin{array}{l}\text { Configurati } \\
\text { on }\end{array}$ & Direct covered access to SATS on Exterior & \\
\hline SATS & Size & $8^{\prime} \times 20^{\prime} \times 8^{\prime}$ & \\
\hline SATS & Location & Adjacent to Tool Room & \\
\hline Connectivity & Location & Connectivity to building with SATS is required. & \\
\hline
\end{tabular}




\begin{tabular}{|c|c|c|c|}
\hline Awning & Size & $\begin{array}{l}\text { Minimum } 14 \text { foot clear height above hardstand } \\
\text { for weather protection of SATS }\end{array}$ & \\
\hline Reception window & Location & Counter to Corridor & \\
\hline Reception window & Type & Lockable, coiling shutter & \\
\hline Personnel Doors & Location & To Circulation Bay & \\
\hline Personnel Doors & Type & Lockable & \\
\hline \multicolumn{4}{|c|}{ Core Areas - Tool Box Storage } \\
\hline $\begin{array}{l}\text { Components } \\
\text { Affected }\end{array}$ & Issue & Requirement & $\begin{array}{l}\text { Reference } \\
\text { Code }\end{array}$ \\
\hline N/A & Location & One per repair wing & \\
\hline Personnel Doors & Location & To Circulation Bay & \\
\hline Personnel Doors & Type & Lockable, With closer & \\
\hline \multicolumn{4}{|c|}{ Core Areas - Combat Spares } \\
\hline $\begin{array}{l}\text { Components } \\
\text { Affected }\end{array}$ & Issue & Requirement & $\begin{array}{l}\text { Reference } \\
\text { Code }\end{array}$ \\
\hline N/A & Size & $8^{\prime} \times 20^{\prime} \times 8^{\prime}$ & \\
\hline N/A & $\begin{array}{l}\text { Configurati } \\
\text { on }\end{array}$ & Direct Covered Access to ASL-MS on exterior & \\
\hline Reception window & Location & Counter to Corridor & \\
\hline Reception window & Type & Lockable, coiling shutter & \\
\hline Personnel Doors & Location & To Circulation Bay & \\
\hline Personnel Doors & Type & Lockable & \\
\hline \multicolumn{4}{|l|}{ Core Areas - Latrines } \\
\hline $\begin{array}{l}\text { Components } \\
\text { Affected }\end{array}$ & Issue & Requirement & $\begin{array}{l}\text { Reference } \\
\text { Code }\end{array}$ \\
\hline N/A & Location & Each Floor & \\
\hline N/A & $\begin{array}{l}\text { Configurati } \\
\text { on }\end{array}$ & Separate Men's and Women's & \\
\hline Lighting & $\begin{array}{l}\text { illumination } \\
\text { level }\end{array}$ & $20 \mathrm{FC}$ & \\
\hline N/A & Present & $\begin{array}{l}\text { water closets, urinals, lavatories and drinking } \\
\text { fountains }\end{array}$ & \\
\hline \multicolumn{4}{|c|}{ Core Areas - Showers/Lockers } \\
\hline $\begin{array}{l}\text { Components } \\
\text { Affected }\end{array}$ & Issue & Requirement & $\begin{array}{l}\text { Reference } \\
\text { Code }\end{array}$ \\
\hline N/A & Size & & \\
\hline N/A & Location & 1st floor, Adjacent to Latrine area & \\
\hline Lighting & $\begin{array}{l}\text { illumination } \\
\text { level }\end{array}$ & $20 \mathrm{FC}$ & \\
\hline $\begin{array}{l}\text { Shower } \\
\text { Compartment }\end{array}$ & Size & $3^{\prime} \times 3^{\prime}$ & \\
\hline Lockers & Type & Steel, 1'x1.5'x6' high & \\
\hline \multicolumn{4}{|c|}{ Core Areas - Showers/Lockers } \\
\hline $\begin{array}{l}\text { Components } \\
\text { Affected }\end{array}$ & Issue & Requirement & $\begin{array}{l}\text { Reference } \\
\text { Code }\end{array}$ \\
\hline $\mathrm{N} / \mathrm{A}$ & Location & Same Floor as Admin Shop Control & \\
\hline
\end{tabular}




\begin{tabular}{|c|c|c|c|}
\hline \multicolumn{4}{|l|}{ Size } \\
\hline Lighting & $\begin{array}{l}\text { illumination } \\
\text { level }\end{array}$ & $30 \mathrm{FC}$ & \\
\hline Lighting & Type & Glare free, dimmable ballast & \\
\hline Exterior Windows & Type & Operable & \\
\hline CATV & Outlets & $2 x$ & \\
\hline $\begin{array}{l}\text { Cabinents/Countert } \\
\text { ops }\end{array}$ & Size & 30" deep, 10' long, w/sink & \\
\hline \multicolumn{4}{|c|}{ Core Areas - Showers/Lockers } \\
\hline $\begin{array}{l}\text { Components } \\
\text { Affected }\end{array}$ & Issue & Requirement & $\begin{array}{l}\text { Reference } \\
\text { Code }\end{array}$ \\
\hline Floors/Wall/Ceiling & Security & & \\
\hline Vault Door & Type & GSA Class 5 Armory w/Day gate & $\begin{array}{l}\text { Fed Spec } \\
\text { AA-D-600D }\end{array}$ \\
\hline Interior Partitions & Type & Wire Mesh & \\
\hline N/A & Size & 300 NSF & \\
\hline Roof & Security & Concrete Roof Caps & \\
\hline Exhaust & Operation & Continuous & \\
\hline Exhaust & Optional & ERV & \\
\hline Lighting & $\begin{array}{l}\text { illumination } \\
\text { level }\end{array}$ & $50 \mathrm{FC}$ & \\
\hline Intrusion Detection & Security & Present & \\
\hline \multicolumn{4}{|c|}{ Core Areas - Showers/Lockers } \\
\hline $\begin{array}{l}\text { Components } \\
\text { Affected }\end{array}$ & Issue & Requirement & $\begin{array}{l}\text { Reference } \\
\text { Code }\end{array}$ \\
\hline N/A & Size & 300 NSF, Min 8' dimension & \\
\hline Roof & Security & Concrete Roof Caps & AR 380-5 \\
\hline AHU System & Type & Independent, not floor mounted & \\
\hline N/A & Climate & $72 \mathrm{~F}, 50 \%$ relative humidity & \\
\hline Lighting & $\begin{array}{l}\text { illumination } \\
\text { level }\end{array}$ & $50 \mathrm{FC}$ & \\
\hline Intrusion Detection & Security & Present & \\
\hline \multicolumn{4}{|c|}{ Core Areas - Showers/Lockers } \\
\hline $\begin{array}{l}\text { Components } \\
\text { Affected }\end{array}$ & Issue & Requirement & $\begin{array}{l}\text { Reference } \\
\text { Code }\end{array}$ \\
\hline Intrusion Detection & Security & Present & \\
\hline $\mathrm{N} / \mathrm{A}$ & Size & $6^{\prime} \times 6^{\prime}$ & \\
\hline N/A & Location & Adjacent to Telecom Room & \\
\hline \multicolumn{4}{|c|}{ Core Areas - Showers/Lockers } \\
\hline $\begin{array}{l}\text { Components } \\
\text { Affected }\end{array}$ & Issue & Requirement & $\begin{array}{l}\text { Reference } \\
\text { Code }\end{array}$ \\
\hline Lighting & $\begin{array}{l}\text { illumination } \\
\text { level }\end{array}$ & $20 \mathrm{FC}$ & \\
\hline N/A & Size & 300 NSF & AR 190-51 \\
\hline
\end{tabular}




\begin{tabular}{|c|c|c|c|}
\hline \multicolumn{4}{|c|}{ Core Areas - Showers/Lockers } \\
\hline $\begin{array}{l}\text { Components } \\
\text { Affected }\end{array}$ & Issue & Requirement & $\begin{array}{l}\text { Reference } \\
\text { Code }\end{array}$ \\
\hline N/A & Location & $\begin{array}{l}1 \text { room per floor, center of building, stacked } \\
\text { between floors }\end{array}$ & $\begin{array}{l}\text { I3A guide, } \\
\text { ANSI/EIA/TI } \\
\text { A-569-B }\end{array}$ \\
\hline AHU System & Type & Independent, not floor mounted & \\
\hline $\mathrm{N} / \mathrm{A}$ & Climate & $72 \mathrm{~F}, 50 \%$ relative humidity & \\
\hline
\end{tabular}

\begin{tabular}{|c|c|c|}
\hline \multicolumn{3}{|c|}{ Non-Assignable - Stairwells } \\
\hline $\begin{array}{l}\text { Components } \\
\text { Affected }\end{array}$ & Requirement & $\begin{array}{l}\text { Reference } \\
\text { Code }\end{array}$ \\
\hline N/A & $\begin{array}{l}\text { Configurati } \\
\text { on }\end{array}$ & $\begin{array}{l}\text { IAW Local } \\
\text { Codes }\end{array}$ \\
\hline
\end{tabular}

\begin{tabular}{|c|c|c|c|}
\hline \multicolumn{4}{|c|}{ Non-Assignable - Elevators } \\
\hline $\begin{array}{l}\text { Components } \\
\text { Affected }\end{array}$ & Issue & Requirement & $\begin{array}{l}\text { Reference } \\
\text { Code }\end{array}$ \\
\hline Elevator & Location & one per two story building & \\
\hline
\end{tabular}

\begin{tabular}{|c|c|c|c|}
\hline \multicolumn{4}{|c|}{ Non-Assignable - Circulation Corridors } \\
\hline $\begin{array}{l}\text { Components } \\
\text { Affected }\end{array}$ & Issue & Requirement & $\begin{array}{l}\text { Reference } \\
\text { Code }\end{array}$ \\
\hline N/A & Size & Min 6' Wide & \\
\hline \multicolumn{4}{|c|}{ Non-Assignable - Waiting Area } \\
\hline $\begin{array}{l}\text { Components } \\
\text { Affected }\end{array}$ & Issue & Requirement & $\begin{array}{l}\text { Reference } \\
\text { Code }\end{array}$ \\
\hline N/A & Size & Accommodates 4 person seating & \\
\hline N/A & Location & $\begin{array}{l}\text { Adjacent to Admin and shop control pass-through } \\
\text { window }\end{array}$ & \\
\hline
\end{tabular}

$\begin{array}{llll}\begin{array}{l}\text { Non-Assignable - Janitorial Spaces } \\ \text { Components }\end{array} & \text { Issue } & \text { Requirement } & \text { Reference } \\ \text { Affected } & \text { Present } & \text { Yes } & \text { Code } \\ \text { Service Sink } & \text { Present } & \text { Yes } \\ \text { Heavy Duty Sink } & \text { Optional } & \text { Recycling function } & \\ \text { Recycling } & \text { Pes }\end{array}$

\begin{tabular}{|c|c|c|c|}
\hline \multicolumn{4}{|c|}{ Non-Assignable - Mechanical Spaces } \\
\hline $\begin{array}{l}\text { Components } \\
\text { Affected }\end{array}$ & Issue & Requirement & $\begin{array}{l}\text { Reference } \\
\text { Code }\end{array}$ \\
\hline $\mathrm{AHU}$ & Location & Utility space provided & \\
\hline N/A & Location & Adjacent to Exterior Wall, stacked between floors & \\
\hline Hose Bib & Location & In each Room & \\
\hline Walls & Sound & STC $>45$ & \\
\hline Lighting & $\begin{array}{l}\text { illumination } \\
\text { level }\end{array}$ & $30 \mathrm{FC}$ & \\
\hline
\end{tabular}

\begin{tabular}{|c|c|c|c|}
\hline \multicolumn{4}{|c|}{ Non-Assignable - Electrical Room } \\
\hline $\begin{array}{l}\text { Components } \\
\text { Affected }\end{array}$ & Issue & Requirement & $\begin{array}{l}\text { Reference } \\
\text { Code }\end{array}$ \\
\hline $\mathrm{N} / \mathrm{A}$ & Locatior & Adjacent to Ex & \\
\hline
\end{tabular}


$\begin{array}{ll}\text { Lighting } & \text { illumination } 30 \mathrm{FC} \\ \text { level }\end{array}$

\begin{tabular}{|c|c|c|c|}
\hline \multicolumn{4}{|c|}{ Non-Assignable - Fluid Distribution Room } \\
\hline $\begin{array}{l}\text { Components } \\
\text { Affected }\end{array}$ & Issue & Requirement & $\begin{array}{l}\text { Reference } \\
\text { Code }\end{array}$ \\
\hline $\mathrm{N} / \mathrm{A}$ & Location & Near Maintenance Pit & $\begin{array}{l}\text { UFC 3-600- } \\
\text { 01, FFPA } \\
30, \text { and } 29 \\
\text { CFR } \\
1910.105\end{array}$ \\
\hline N/A & Size & Accommodate POL storage containers & $\begin{array}{l}\text { UFC 3-600- } \\
\text { 01, FFPA } \\
30, \text { and } 29 \\
\text { CFR } \\
1910.106\end{array}$ \\
\hline $\mathrm{N} / \mathrm{A}$ & $\begin{array}{l}\text { Environme } \\
\mathrm{nt}\end{array}$ & EPA compliant & \\
\hline
\end{tabular}

Non-Assignable - Fluid Distribution Room

\begin{tabular}{|c|c|c|}
\hline $\begin{array}{l}\text { Components } \\
\text { Affected }\end{array}$ & Issue Requirement & $\begin{array}{l}\text { Reference } \\
\text { Code }\end{array}$ \\
\hline
\end{tabular}

N/A Location Provide one per test site

Electric Power Present Yes

Grounding Points Present Yes

\begin{tabular}{|c|c|c|c|}
\hline $\begin{array}{l}\text { Components } \\
\text { Affected }\end{array}$ & Issue & Requirement & $\begin{array}{l}\text { Reference } \\
\text { Code }\end{array}$ \\
\hline
\end{tabular}

Pavement Type Rigid

Pavement Capacity Supports heaviest vehicle

Pavement $\quad$ Slope $\quad 1 \% \min , 2 \% \max$

Electrical Power Load $200 \mathrm{amp}, 208 \mathrm{~V}, 3 \mathrm{ph}$

Telecom Connection Fiber Optic terminal connections

$\mathrm{S}$

Organizational Vehicle Hardstand - Tactical / Military Vehicle

$\begin{array}{llll}\begin{array}{l}\text { Components } \\ \text { Affected }\end{array} & \text { Issue } & \text { Requirement } & \begin{array}{l}\text { Reference } \\ \text { Code }\end{array} \\ \text { N/A } & \text { Clearance } & 3^{\prime} \text { 'side, 2' end } & \end{array}$

Organizational Vehicle Hardstand - POL

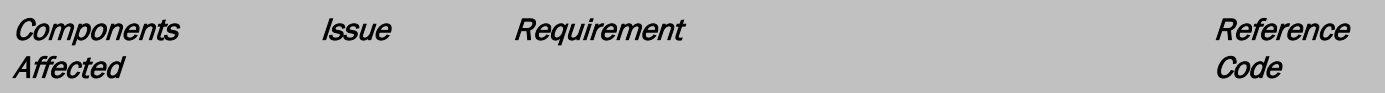

N/A Location Physically separate from hardstand

Organizational Vehicle Hardstand - Dead-Line

Components Issue Requirement Reference

Affected Code

N/A Location Adjacent to repair bays

N/A Clearance $\quad 3$ ' side, $2^{\prime}$ end 


\begin{tabular}{|c|c|c|c|}
\hline \multicolumn{4}{|c|}{ Organizational Vehicle Hardstand - Building Aprons } \\
\hline $\begin{array}{l}\text { Components } \\
\text { Affected }\end{array}$ & Issue & Requirement & $\begin{array}{l}\text { Reference } \\
\text { Code }\end{array}$ \\
\hline $\mathrm{N} / \mathrm{A}$ & Size & 45' wide & \\
\hline $\mathrm{N} / \mathrm{A}$ & Location & All sides of building & \\
\hline \multicolumn{4}{|l|}{ Site Storage } \\
\hline $\begin{array}{l}\text { Components } \\
\text { Affected }\end{array}$ & Issue & Requirement & $\begin{array}{l}\text { Reference } \\
\text { Code }\end{array}$ \\
\hline Lighting & $\begin{array}{l}\text { illumination } \\
\text { level }\end{array}$ & $20 \mathrm{FC}$ & \\
\hline Structure & Type & Solid Walls and Roof & \\
\hline Bollards & Size & 12" dia, 5' height & \\
\hline Bollards & Type & Concrete filled steel & \\
\hline Bollards & Location & $\begin{array}{l}\text { Each side of all OH Door Openings, 5' spacing } \\
\text { around bulk liquid tanks }\end{array}$ & \\
\hline Walls & Type & $\begin{array}{l}\text { Optional use of Solar walls - acts as insulation } \\
\text { based on heating ventilated air. (solarwall.com) }\end{array}$ & \\
\hline \multicolumn{4}{|c|}{ Site Storage - Hazardous Waste } \\
\hline $\begin{array}{l}\text { Components } \\
\text { Affected }\end{array}$ & Issue & Requirement & $\begin{array}{l}\text { Reference } \\
\text { Code }\end{array}$ \\
\hline N/A & Safety & Secondary containment & $\begin{array}{l}\text { UFC 3-600- } \\
\text { 01, NFPA } \\
30, \text { and } 29 \\
\text { CFR } \\
1910.106\end{array}$ \\
\hline $\mathrm{N} / \mathrm{A}$ & Size & Based on number of vehicles; Minimum of 120 SF & \\
\hline Skylights & Day lighting & Dome Type & \\
\hline Heating Plant & Climate & $40 \mathrm{~F}$ & \\
\hline N/A & Location & $\begin{array}{l}\text { Minimum separation distance from other } \\
\text { buildings }\end{array}$ & IBC \\
\hline \multicolumn{4}{|c|}{ Site Storage - POL Storage } \\
\hline $\begin{array}{l}\text { Components } \\
\text { Affected }\end{array}$ & Issue & Requirement & $\begin{array}{l}\text { Reference } \\
\text { Code }\end{array}$ \\
\hline $\mathrm{N} / \mathrm{A}$ & Access & Apron Access to Bldg & \\
\hline N/A & Safety & Secondary containment & $\begin{array}{l}\text { UFC 3-600- } \\
\text { 01, NFPA } \\
30, \text { and } 29 \\
\text { CFR } \\
\text { 1910.106 }\end{array}$ \\
\hline $\mathrm{N} / \mathrm{A}$ & Size & Based on number of vehicles; Minimum of $120 \mathrm{SF}$ & \\
\hline N/A & Location & $\begin{array}{l}\text { Minimum separation distance from other } \\
\text { buildings }\end{array}$ & IBC \\
\hline Skylights & Day lighting & Dome Type & \\
\hline Heating Plant & Climate & $40 \mathrm{~F}$ & \\
\hline \multicolumn{4}{|c|}{ Site Storage - Organizational } \\
\hline $\begin{array}{l}\text { Components } \\
\text { Affected }\end{array}$ & Issue & Requirement & $\begin{array}{l}\text { Reference } \\
\text { Code }\end{array}$ \\
\hline $\mathrm{N} / \mathrm{A}$ & Size & Based on number of vehicles; 45 FT Deep & \\
\hline
\end{tabular}




\begin{tabular}{|c|c|c|c|}
\hline Overhead Doors & Type & Coiling & \\
\hline Overhead Doors & Location & one for each company supply area & \\
\hline $\mathrm{N} / \mathrm{A}$ & $\begin{array}{l}25 \text { ' deep } \\
\text { building }\end{array}$ & & \\
\hline Floor & Capacity & Fork-Lift Safe & \\
\hline Skylights & Day lighting & Dome Type & \\
\hline Heating Plant & Climate & $40 \mathrm{~F}$ & \\
\hline \multicolumn{4}{|c|}{ Site Storage - Distribution Company Storage } \\
\hline $\begin{array}{l}\text { Components } \\
\text { Affected }\end{array}$ & Issue & Requirement & $\begin{array}{l}\text { Reference } \\
\text { Code }\end{array}$ \\
\hline $\mathrm{N} / \mathrm{A}$ & Size & $800 \mathrm{SF}$ & \\
\hline Skylights & Day lighting & Dome Type & \\
\hline Heating Plant & Climate & $55 \mathrm{~F}$ & \\
\hline \multicolumn{4}{|c|}{ Site Storage - Secured Open Storage } \\
\hline $\begin{array}{l}\text { Components } \\
\text { Affected }\end{array}$ & Issue & Requirement & $\begin{array}{l}\text { Reference } \\
\text { Code }\end{array}$ \\
\hline $\mathrm{N} / \mathrm{A}$ & Size & 445 SY & \\
\hline Fence & Location & Fenced Area on Pavement & \\
\hline \multicolumn{4}{|c|}{ Site Storage - UAV Maintenance and Storage } \\
\hline $\begin{array}{l}\text { Components } \\
\text { Affected }\end{array}$ & Issue & Requirement & $\begin{array}{l}\text { Reference } \\
\text { Code }\end{array}$ \\
\hline $\mathrm{N} / \mathrm{A}$ & Size & $40 ' x 45^{\prime}$ building where required & \\
\hline Skylights & Day lighting & Dome Type & \\
\hline Heating Plant & Climate & $55 \mathrm{~F}$ & \\
\hline Supply Fan & IAQ & $\begin{array}{l}100 \% \text { out door air (no re-circ, no return air } \\
\text { plenum) }\end{array}$ & \\
\hline \multicolumn{4}{|c|}{ Site Storage - Oil Storage Tanks } \\
\hline $\begin{array}{l}\text { Components } \\
\text { Affected }\end{array}$ & Issue & Requirement & $\begin{array}{l}\text { Reference } \\
\text { Code }\end{array}$ \\
\hline $\mathrm{N} / \mathrm{A}$ & Type & $\begin{array}{l}500 \mathrm{Gal} \text {, above ground, non corrosive, secondary } \\
\text { containment }\end{array}$ & IBC \\
\hline $\mathrm{N} / \mathrm{A}$ & Location & Adjacent to repair area, and used POL storage & IBC \\
\hline \multicolumn{4}{|c|}{ Site Storage - Engine Coolant Storage Tanks } \\
\hline $\begin{array}{l}\text { Components } \\
\text { Affected }\end{array}$ & Issue & Requirement & $\begin{array}{l}\text { Reference } \\
\text { Code }\end{array}$ \\
\hline $\mathrm{N} / \mathrm{A}$ & Type & $\begin{array}{l}500 \text { Gal, above ground, non corrosive, secondary } \\
\text { containment }\end{array}$ & IBC \\
\hline N/A & Location & Adjacent to repair area, and used POL storage & IBC \\
\hline \multicolumn{4}{|c|}{ Site Storage - Out of Sep Waste Fuel Tanks } \\
\hline $\begin{array}{l}\text { Components } \\
\text { Affected }\end{array}$ & Issue & Requirement & $\begin{array}{l}\text { Reference } \\
\text { Code }\end{array}$ \\
\hline N/A & Type & $\begin{array}{l}500 \text { Gal, above ground, non corrosive, secondary } \\
\text { containment }\end{array}$ & IBC \\
\hline N/A & Location & Adjacent to repair area, and used POL storage & IBC \\
\hline
\end{tabular}




\begin{tabular}{|c|c|c|c|}
\hline \multicolumn{4}{|c|}{ Site Storage - Security Fence } \\
\hline $\begin{array}{l}\text { Components } \\
\text { Affected }\end{array}$ & Issue & Requirement & $\begin{array}{l}\text { Reference } \\
\text { Code }\end{array}$ \\
\hline Fence & Type & 7' Chain link fabric, 3 strand barbed wire & $\begin{array}{l}\text { UFC 4-010- } \\
\text { 01, and } \\
\text { STD 872- } \\
90-03, \text { FE-6 }\end{array}$ \\
\hline Fence & Clearance & Clear zone $20^{\prime}$ wide inside fence, $10^{\prime}$ wide outside & \\
\hline Gates & Size & 30' vehicle gates & \\
\hline \multicolumn{4}{|l|}{ Other Site Features } \\
\hline $\begin{array}{l}\text { Components } \\
\text { Affected }\end{array}$ & Issue & Requirement & $\begin{array}{l}\text { Reference } \\
\text { Code }\end{array}$ \\
\hline Oil water separator & Present & Yes & \\
\hline $\begin{array}{l}\text { Utility monitoring } \\
\text { control system }\end{array}$ & Present & Yes & \\
\hline $\begin{array}{l}\text { Pole Mounted } \\
\text { Exterior Lighting }\end{array}$ & Type & HID fixtures, photo sensor controlled, <0.5 FCs & \\
\hline $\begin{array}{l}\text { Bldg Mounted } \\
\text { Exterior Lighting }\end{array}$ & Type & Fluorescent or HID & \\
\hline Exterior Materials & Aesthetics & Attractive & \\
\hline Exterior Materials & Durability & Low Maintenance & \\
\hline Fire Protection & Location & All areas covered & $\begin{array}{l}\text { UFC 3-600- } \\
01, \text { NFPA } \\
13 \text {, and IBC }\end{array}$ \\
\hline Fire Protection & Type & $\begin{array}{l}\text { Wet pipe for heated spaces, dry pipe for non- } \\
\text { heated spaces }\end{array}$ & \\
\hline Air Compressor & Capacity & Provide 120 psi air & \\
\hline Lightning protection & Present & Yes & \\
\hline $\begin{array}{l}\text { Transient Voltage } \\
\text { Surge Protection }\end{array}$ & Present & Yes & \\
\hline Electrical Service & Type & 3 ph, 200 amp breaker in main switchboard & \\
\hline Electrical Service & Distribution & $\begin{array}{l}\text { Receptacles to each workstation, duplex receptacle } \\
\text { each voice/data, and CATV outlet }\end{array}$ & adjacent to \\
\hline Data & Distribution & Cat 6 cabling for all voice and data connections & \\
\hline Fire detection alarm & Type & Assignable & \\
\hline
\end{tabular}




\section{Appendix H: User Input Design Issues for Tactical Equipment Maintenance Facilities (TEMF)}

\author{
Area/Component: \\ Problem: \\ Proposed Solution: \\ Area/Component: \\ Problem: \\ Proposed Solution:
}

Area/Component:

Problem:

Proposed Solution:

Area/Component:

Problem:

Proposed Solution:

Area/Component:

Problem:

Proposed Solution:

Area/Component:

Problem:

Proposed Solution:

Area/Component:

Problem:
Maint/Repair Bays - Concrete Flooring

The concrete floor slab in the maintenance/repair areas is unsealed. This makes it difficult to adequately clean up oil spills that occasionally occur, and it leaves oil stains on the floor.

Seal Concrete Floor

Maint/Repair Bays - Concrete Flooring

Lines Painted on the concrete floor slab in the maint/repair area.

Do not paint lines on floor slab. Each unit will configure space to best conduct operations.

Welding Area

The welding area is in the first bay by the core admin area, so it is an increased hazard for occupants walking out of admin spaces

Move welding area to the bay farthest from core admin area. In addition, install welding curtains area space (but make sure any partition does not affect access to emergency eye wash station.

\section{Emergency Eye Wash Station}

Emergency Eye Wash Station drains to central drain in welding bay, causing a potential safety hazard due to exposure to electrical shock.

Relocate eyewash station or re-route drainage to perimeter drainage

Latrine Capacity

There is only one urinal each in upstairs and downstairs latrines. This is not sufficient capacity to support the number of troops occupying facility during peak use times.

Add additional fixtures to account for additional occupants if needed.

\section{Locker Capacity}

There are only 42 lockers or cubby stations in the downstairs locker room. However, there can be 80 people or more occupying the facility during training, each requiring locker space.

Add additional lockers if needed.

\section{Break Room}

The break room doubles as a conference room. There is not a dedicated break room to use when conference room is being occupied during training or planning exercises. 
Proposed Solution:

Area/Component:

Problem:

Proposed Solution:

Area/Component:

Problem:

Proposed Solution:

Area/Component:

Problem:

Proposed Solution:

Area/Component:

Problem:

Proposed Solution:

Area/Component:

Problem:

Proposed Solution:

Area/Component:

Problem:

Proposed Solution:

Area/Component:

Problem:

Proposed Solution:

Area/Component:

Problem:

Proposed Solution:
Add space for separate break room if needed

2nd Floor Windows

Windows are not operable on the second floor. Cannot run wires and cabling from outside equipment (satellites, etc) to training rooms inside.

Run conduit for connection to equipment outside.

Outside equipment pads and mounting

The satellite that feeds information for the SAMS system (maintenance and parts tracking system) is just set on the ground

Need a permanent place mounted off the ground. (Note that they are building a pad and running conduit cabling for this.)

Hardstand / Exterior Lighting

Cannot maneuver vehicles (especially lowboy trailers in excess of 45' in length) around light posts on the outside hardstand.

Provide only perimeter lighting, with limited interior light posts. Exterior lighting is more than adequate, and most vehicles already have own lighting systems.

2nd Floor Admin Area - Communication to Maint/Repair Bays

There is no way to communicate from the upstairs admin spaces to the repair bays below, no phones or operable windows.

Provide occupant training on building intercom system.

Fluid Distribution Room

Door to Fluid Distribution Room is too narrow to get a forklift with a palate of POL drums in.

Provide wider door, or overhead door to Fluid Distribution Room

Consolidated Bench Room - Partitions

There is no partition between classified equipment repair and non-classified equipment repair areas.

Provide lockable cage partition between repair areas in consolidated bench repair room.

\section{Air Compressor}

Air compressor does not run the air tools (does not supply the minimum necessary psi), especially when multiple stations are using air at the same time.

Size or adjust the compressor to provide 150 psi continuous air supply.

\section{Component Parts Wash}

No list of approved detergents

Provide a list of approved detergents for the component parts wash 
Area/Component:

Problem:

Proposed Solution:

Area/Component:

Problem:

Proposed Solution:

Area/Component:

Problem:

Proposed Solution:

Area/Component:

Problem:

Proposed Solution:

Area/Component:

Problem:

Proposed Solution:
Maintenance Pit

Cannot pump used POL out of pit. Need to carry out by hand.

Provide a sump pump to remove used POL fluids.

Maintenance Pit - Location

Maintenance Pit is too close to wall and consolidated bench repair door. Cannot make the turn to get forklift in when servicing vehicle

Relocate Maintenance Pit

Waterless Urinals

No information on required maintenance for waterless urinals provided to occupants

Provide information on when and how to replace cartridges, and where to get them.

\section{2nd Floor beams}

Exposed ceiling in the combat spares and consolidated bench area. Exposed floor beams above for $2^{\text {nd }}$ floor admin space need to be protected for fire.

There is currently a plan to enclose the ceiling in combat spares and consolidated bench area.

Admin Area - Size

There is not enough admin office space (or data ports) for all of the tenants/users or support teams that work in conjunction in the facility. There is no space for a SPO (Support Operations Cell), while there is space for BLST

No office with a door for field grade officers in a supervisory position. Need at least one shared office for MCO (Maint Control Officer), MCS (Maint Control Specialist), and BMT (Battalion Maint Technician)

Notify supervisors that there is office space in the COF to council personnel. Mechanical/Electrical Rooms have large empty/unused area. Consolidated bench may also have more space than required. Repurpose some of these spaces to provide separate office and more admin space if needed. 


\section{Appendix I: EPACT Facility Criteria}

\begin{tabular}{|c|c|c|}
\hline Component & Issue & Detail \\
\hline \multirow[t]{3}{*}{ Roof } & Insulation Above Deck & \\
\hline & Metal building Roof & $\mathrm{R}-13+\mathrm{R}-13$ \\
\hline & Surface Reflectance & 0.65 \\
\hline \multirow[t]{2}{*}{ Walls } & Steel framed & \\
\hline & Metal & $\mathrm{R}-13$ \\
\hline \multirow[t]{2}{*}{ Slabs } & Unheated & NR \\
\hline & Heated & $\mathrm{R}-10$ \\
\hline \multirow[t]{2}{*}{ Doors } & Swinging & $\mathrm{U}-0.70$ \\
\hline & Non-Swinging & $\mathrm{U}-0.25$ \\
\hline Infiltration & & $0.5 \mathrm{ACH}$ \\
\hline \multirow[t]{4}{*}{ Vertical Glazing } & Window to Wall Ratio & $<10 \%$ \\
\hline & Thermal Transmittance & $\mathrm{U}-0.45$ \\
\hline & Solar Heat gain coefficient (SHGC) & 0.44-N, 0.31-S, E, W \\
\hline & South Overhangs & NR \\
\hline \multirow[t]{3}{*}{ Skylights } & $\%$ roof area & $2 \%$ \\
\hline & Thermal Transmittance & U-0.69 \\
\hline & SHGC & 0.19 \\
\hline \multirow[t]{4}{*}{ Interior Lighting } & Lighting Power Density & \\
\hline & Ballast & Electronic \\
\hline & Day lighting Controls & Yes \\
\hline & Occupancy Controls & all unoccupied spaces \\
\hline \multirow[t]{5}{*}{ HVAC } & Make Up Air Unit Fans & \\
\hline & Air Conditioner & 14 SEER \\
\hline & Gas Coil & $90 \% \mathrm{E}$ \\
\hline & Hydronic Radiant Floor Heat & Ground Floor \\
\hline & ERV & Yes \\
\hline Economizer & & NR \\
\hline \multirow[t]{3}{*}{ Ventilation } & Outdoor Air Damper & Motorized Control \\
\hline & Demand Control & Yes \\
\hline & Transpired Solar Collector & Yes \\
\hline \multirow[t]{3}{*}{ Ducts } & Sealing & Seal Class B \\
\hline & Location & Interior Only \\
\hline & Insulation Level & $\mathrm{R}-6$ \\
\hline \multicolumn{3}{|l|}{ Service Water } \\
\hline Heating & Gas Storage & $90 \% \mathrm{E}$ \\
\hline
\end{tabular}




\section{Appendix J: BUILDER FI Interval Mapping to ISR-I Definitions}

\section{ISR-I Functionality Definitions}

\begin{tabular}{|l|l|}
\hline ISR-I Rating & ISR-I Proposed Definitions \\
\hline F1 & $\begin{array}{l}\text { Minimal or no facility condition deficiencies with negligible or no impact on the } \\
\text { capability to support the tenant organizations' required missions }\end{array}$ \\
\hline F2 & $\begin{array}{l}\text { Moderate facility functional/configuration deficiencies that have limited impact } \\
\text { on the capability to support the tenant organizations' required missions. All } \\
\text { essential/critical functional elements exist }\end{array}$ \\
\hline F3 & $\begin{array}{l}\text { Significant facility functional/configuration deficiencies that impair the capability } \\
\text { to support some of the tenant organizations required missions. Some } \\
\text { essential/critical functional elements may be missing }\end{array}$ \\
\hline F4 & $\begin{array}{l}\text { Major facility functional/configuration deficiencies that present considerable } \\
\text { obstacles to the tenant organizations' accomplishment of required missions. } \\
\text { Some essential/critical functional elements missing. All temporary facilities are } \\
\text { F4 }\end{array}$ \\
\hline F5 & $\begin{array}{l}\text { Asset is non-functional and cannot be occupied. Out of service pending } \\
\text { completion of renovation, repair of weather damage, remediation of } \\
\text { environmental contamination, etc }\end{array}$ \\
\hline
\end{tabular}




\section{ISR-BUILDER Integrated Definitions}

\begin{tabular}{|c|c|c|c|c|}
\hline $\begin{array}{l}\text { ISR-I } \\
\text { Rating }\end{array}$ & $\begin{array}{l}\mathrm{FI} \\
\text { Range }\end{array}$ & $\begin{array}{l}\text { Short } \\
\text { Description }\end{array}$ & Functional Impairment Description & Modernization Needs \\
\hline F1 & $100-85$ & $\begin{array}{l}\text { Minimal to } \\
\text { slight } \\
\text { functional } \\
\text { impairment }\end{array}$ & $\begin{array}{l}\text { All user requirements, codes, and } \\
\text { compliance issues are largely met, with } \\
\text { no impact on mission. } \\
\text { A small number of secondary functional } \\
\text { spaces may impair capabilities slightly } \\
\text { due to configuration. } \\
\text { A limited number of non-critical } \\
\text { components may not meet requirements }\end{array}$ & $\begin{array}{l}\text { Negligible overall building } \\
\text { modernization } \\
\text { Slight reconfiguration in a few } \\
\text { functional areas } \\
\text { Replacement of a few minor } \\
\text { components }\end{array}$ \\
\hline F2 & $85-55$ & $\begin{array}{l}\text { Minor to } \\
\text { Moderate } \\
\text { functional } \\
\text { impairment }\end{array}$ & $\begin{array}{l}\text { User requirements, codes, and } \\
\text { compliance largely met, with only minor } \\
\text { impact on mission. } \\
\text { The configuration in some functional } \\
\text { spaces has a limited impact on mission } \\
\text { operations. } \\
\text { A moderate number of mostly non-critical } \\
\text { components do not meet minimum } \\
\text { requirements. }\end{array}$ & $\begin{array}{l}\text { Minor overall building modernization } \\
\text { Moderate reconfiguration of building } \\
\text { functional areas } \\
\text { Replacement of a limited number of } \\
\text { components, mostly non-critical }\end{array}$ \\
\hline F3 & $55-40$ & $\begin{array}{l}\text { Significant } \\
\text { functional } \\
\text { impairment }\end{array}$ & $\begin{array}{l}\text { A moderate number of basic } \\
\text { requirements are not met, significantly } \\
\text { impairing the capability of the facility } \\
\text { The configuration in many functional } \\
\text { spaces has significant impact on mission } \\
\text { operations } \\
\text { An significant number of components } \\
\text { (critical and non-critical) do not meet } \\
\text { minimum requirements }\end{array}$ & $\begin{array}{l}\text { Significant overall building } \\
\text { modernization } \\
\text { Extensive reconfiguration of building } \\
\text { functional areas } \\
\text { Replacement of a significant number } \\
\text { of components, including critical }\end{array}$ \\
\hline F4 & $40-10$ & $\begin{array}{l}\text { Major to } \\
\text { Extensive } \\
\text { functional } \\
\text { impairment }\end{array}$ & $\begin{array}{l}\text { Building presents considerable obstacles } \\
\text { to meeting basic user requirements, or } \\
\text { building is temporary. } \\
\text { The configuration of the functional } \\
\text { spaces greatly impairs critical mission } \\
\text { operations. } \\
\text { An extensive number of critical } \\
\text { components are missing, or do not meet } \\
\text { minimum requirements. }\end{array}$ & $\begin{array}{l}\text { Major overall building modernization, } \\
\text { Relocation or MILCON } \\
\text { Total renovation of all functional } \\
\text { spaces } \\
\text { Replacement of most or all } \\
\text { components }\end{array}$ \\
\hline F5 & $10-0$ & $\begin{array}{l}\text { Total } \\
\text { functional } \\
\text { impairment }\end{array}$ & $\begin{array}{l}\text { Overall Building is largely non-Functional } \\
\text { for current use. }\end{array}$ & Relocation or MILCON \\
\hline
\end{tabular}




\section{Appendix K: Army ISR-I Mapping to BUILDER Functionality Criteria, Administrative Facilities}

\begin{tabular}{|c|c|c|c|}
\hline $\begin{array}{l}\text { ISR-I } \\
\text { Component }\end{array}$ & ISR-I Sub Component & ISR-I Priority & \\
\hline $\begin{array}{l}\text { Sites and } \\
\text { Grounds }\end{array}$ & Site and Grounds Lighting & High & \\
\hline ISR-I Rating & ISR-I Criteria & $\begin{array}{l}\text { BUILDER } \\
\text { Category }\end{array}$ & $\begin{array}{l}\text { BUILDER Sub } \\
\text { Issue }\end{array}$ \\
\hline Green & Security & Access & Building Entry \\
\hline Green & Signage & Access & Building Entry \\
\hline Green & Landscape & Access & Building Entry \\
\hline Amber & $\begin{array}{l}\text { Not more than } 1 \text { of the } 4 \text { types of lighting in } \\
\text { the Green Column }\end{array}$ & Access & Building Entry \\
\hline Red & $\begin{array}{l}\text { Two or more of the } 4 \text { types of lighting in the } \\
\text { Green Column are missing }\end{array}$ & Access & Building Entry \\
\hline Red & No site and ground lighting exists & Access & Building Entry \\
\hline $\begin{array}{l}\text { ISR-I } \\
\text { Component }\end{array}$ & ISR-I Sub Component & ISR-I Priority & \\
\hline $\begin{array}{l}\text { Sites and } \\
\text { Grounds }\end{array}$ & Disabled Access & High & \\
\hline ISR-I Rating & ISR-I Criteria & $\begin{array}{l}\text { BUILDER } \\
\text { Category }\end{array}$ & $\begin{array}{l}\text { BUILDER Sub } \\
\text { Issue }\end{array}$ \\
\hline Green & $\begin{array}{l}\text { Curb ramps are present wherever accessible } \\
\text { routes cross a curb }\end{array}$ & Accessibility & ABA compliance \\
\hline Green & Ramps are a minimum of 3 feet wide & Accessibility & ABA compliance \\
\hline Green & $\begin{array}{l}\text { Ramps have a moderate slope, not } \\
\text { exceeding a rise of } 1: 12 \text { inches horizontally }\end{array}$ & Accessibility & ABA compliance \\
\hline Green & $\begin{array}{l}\text { Access across the site follows the shortest } \\
\text { accessible route to the facility }\end{array}$ & Accessibility & ABA compliance \\
\hline Amber & $\begin{array}{l}1 \text { or } 2 \text { of the } 4 \text { types of lighting in the Green } \\
\text { column missing }\end{array}$ & Accessibility & ABA compliance \\
\hline Red & $\begin{array}{l}\text { More than } 2 \text { of the accessible criteria } \\
\text { elements in the Green column are missing }\end{array}$ & Accessibility & ABA compliance \\
\hline $\begin{array}{l}\text { ISR-I } \\
\text { Component }\end{array}$ & ISR-I Sub Component & ISR-I Priority & \\
\hline $\begin{array}{l}\text { Sites and } \\
\text { Grounds }\end{array}$ & Turf and Pavement Drainage & High & \\
\hline ISR-I Rating & ISR-I Criteria & $\begin{array}{l}\text { BUILDER } \\
\text { Category }\end{array}$ & $\begin{array}{l}\text { BUILDER Sub } \\
\text { Issue }\end{array}$ \\
\hline Green & $\begin{array}{l}\text { No access the site that follows the shortest } \\
\text { accessible to the facility }\end{array}$ & Drainage & \\
\hline
\end{tabular}




\begin{tabular}{|c|c|c|c|}
\hline Amber & $\begin{array}{l}\text { Some debris lying along pavement drainage } \\
\text { channels }\end{array}$ & Drainage & \\
\hline $\begin{array}{l}\text { ISR-I } \\
\text { Component }\end{array}$ & ISR-I Sub Component & ISR-I Priority & \\
\hline $\begin{array}{l}\text { Sites and } \\
\text { Grounds }\end{array}$ & Paved Sidewalks & Medium & \\
\hline ISR-I Rating & ISR-I Criteria & $\begin{array}{l}\text { BUILDER } \\
\text { Category }\end{array}$ & $\begin{array}{l}\text { BUILDER Sub } \\
\text { Issue }\end{array}$ \\
\hline Green & Installed from parking to facility & Access & Building Entry \\
\hline Green & Installed from adjacent streets to facility & Access & Building Entry \\
\hline Green & At least 4 feet wide & Access & Building Entry \\
\hline Amber & Not installed from parking to facility & Access & Building Entry \\
\hline Amber & Not installed from streets to facility & Access & Building Entry \\
\hline Amber & Less than 4 feet wide & Access & Building Entry \\
\hline Red & Not installed at all & Access & Building Entry \\
\hline $\begin{array}{l}\text { ISR-I } \\
\text { Component }\end{array}$ & ISR-I Sub Component & ISR-I Priority & \\
\hline $\begin{array}{l}\text { Sites and } \\
\text { Grounds }\end{array}$ & Landscaping & Low & \\
\hline ISR-I Rating & ISR-I Criteria & $\begin{array}{l}\text { BUILDER } \\
\text { Category }\end{array}$ & $\begin{array}{l}\text { BUILDER Sub } \\
\text { Issue }\end{array}$ \\
\hline Green & $\begin{array}{l}\text { Displays a mixture of colorful plants and } \\
\text { greenery appropriate to the area }\end{array}$ & Aesthetics & $\begin{array}{l}\text { Exterior } \\
\text { Aesthetics }\end{array}$ \\
\hline Amber & Displays few color plantings or greenery & Aesthetics & $\begin{array}{l}\text { Exterior } \\
\text { Aesthetics }\end{array}$ \\
\hline Red & No plantings & Aesthetics & $\begin{array}{l}\text { Exterior } \\
\text { Aesthetics }\end{array}$ \\
\hline $\begin{array}{l}\text { ISR-I } \\
\text { Component }\end{array}$ & ISR-I Sub Component & ISR-I Priority & \\
\hline $\begin{array}{l}\text { Sites and } \\
\text { Grounds }\end{array}$ & Dumpster & Low & \\
\hline ISR-I Rating & ISR-I Criteria & $\begin{array}{l}\text { BUILDER } \\
\text { Category }\end{array}$ & $\begin{array}{l}\text { BUILDER Sub } \\
\text { Issue }\end{array}$ \\
\hline Green & $\begin{array}{l}\text { Screened by walls or landscaping high } \\
\text { enough (6-8ft) to restrict view from: Building } \\
\text { Occupants }\end{array}$ & Aesthetics & $\begin{array}{l}\text { Exterior } \\
\text { Aesthetics }\end{array}$ \\
\hline Green & $\begin{array}{l}\text { Screened by walls or landscaping high } \\
\text { enough ( } 6-8 \mathrm{ft}) \text { to restrict view from: } \\
\text { Entrances }\end{array}$ & Aesthetics & $\begin{array}{l}\text { Exterior } \\
\text { Aesthetics }\end{array}$ \\
\hline Green & $\begin{array}{l}\text { Screened by walls or landscaping high } \\
\text { enough ( } 6-8 \mathrm{ft}) \text { to restrict view from: Streets }\end{array}$ & Aesthetics & $\begin{array}{l}\text { Exterior } \\
\text { Aesthetics }\end{array}$ \\
\hline Green & $\begin{array}{l}\text { Screened by walls or landscaping high } \\
\text { enough ( } 6-8 \mathrm{ft}) \text { to restrict view from: Parking } \\
\text { Lots }\end{array}$ & Aesthetics & $\begin{array}{l}\text { Exterior } \\
\text { Aesthetics }\end{array}$ \\
\hline Green & $\begin{array}{l}33 \text { feet or more away from other occupied } \\
\text { buildings }\end{array}$ & AT/FP & $\begin{array}{l}\text { ATFP } \\
\text { Requirements }\end{array}$ \\
\hline Green & $\begin{array}{l}82 \text { feet or more away from billeting or } \\
\text { housing }\end{array}$ & AT/FP & $\begin{array}{l}\text { ATFP } \\
\text { Requirements }\end{array}$ \\
\hline
\end{tabular}




\begin{tabular}{|c|c|c|c|}
\hline Amber & $\begin{array}{l}\text { Not screened by walls or landscaping } \\
\text { sufficiently high to obscure view }\end{array}$ & Aesthetics & $\begin{array}{l}\text { Exterior } \\
\text { Aesthetics }\end{array}$ \\
\hline Amber & $\begin{array}{l}\text { More than } 20 \text { feet away, but less than } 33 \\
\text { feet away from other occupied facilities }\end{array}$ & AT/FP & $\begin{array}{l}\text { ATFP } \\
\text { Requirements }\end{array}$ \\
\hline Amber & $\begin{array}{l}\text { More than } 50 \text { feet away, but less than } 82 \\
\text { feet away from billeting or housing }\end{array}$ & AT/FP & $\begin{array}{l}\text { ATFP } \\
\text { Requirements }\end{array}$ \\
\hline Red & Not enclosed or screened from view & Aesthetics & $\begin{array}{l}\text { Exterior } \\
\text { Aesthetics }\end{array}$ \\
\hline Red & $\begin{array}{l}\text { Less than } 20 \text { feet away from other occupied } \\
\text { facilities }\end{array}$ & AT/FP & $\begin{array}{l}\text { ATFP } \\
\text { Requirements }\end{array}$ \\
\hline Red & $\begin{array}{l}\text { Less than } 50 \text { feet away from billeting or } \\
\text { housing }\end{array}$ & AT/FP & $\begin{array}{l}\text { ATFP } \\
\text { Requirements }\end{array}$ \\
\hline $\begin{array}{l}\text { ISR-I } \\
\text { Component }\end{array}$ & ISR-I Sub Component & ISR-I Priority & \\
\hline $\begin{array}{l}\text { Sites and } \\
\text { Grounds }\end{array}$ & Utility Services & Low & \\
\hline ISR-I Rating & ISR-I Criteria & $\begin{array}{l}\text { BUILDER } \\
\text { Category }\end{array}$ & $\begin{array}{l}\text { BUILDER Sub } \\
\text { Issue }\end{array}$ \\
\hline Green & All utility lines are underground & Aesthetics & $\begin{array}{l}\text { Exterior } \\
\text { Aesthetics }\end{array}$ \\
\hline Green & $\begin{array}{l}\text { Utility equipment is screened by landscaping } \\
\text { or fencing }\end{array}$ & Aesthetics & $\begin{array}{l}\text { Exterior } \\
\text { Aesthetics }\end{array}$ \\
\hline Amber & Utility lines are not underground & Aesthetics & $\begin{array}{l}\text { Exterior } \\
\text { Aesthetics }\end{array}$ \\
\hline Amber & $\begin{array}{l}\text { Utility equipment is screened by landscaping } \\
\text { or fencing }\end{array}$ & Aesthetics & $\begin{array}{l}\text { Exterior } \\
\text { Aesthetics }\end{array}$ \\
\hline Red & $\begin{array}{l}\text { Utility lines and equipment are exposed and } \\
\text { disorderly }\end{array}$ & Aesthetics & $\begin{array}{l}\text { Exterior } \\
\text { Aesthetics }\end{array}$ \\
\hline $\begin{array}{l}\text { ISR-I } \\
\text { Component }\end{array}$ & ISR-I Sub Component & ISR-I Priority & \\
\hline Parking & Disabled Parking & High & \\
\hline ISR-I Rating & ISR-I Criteria & $\begin{array}{l}\text { BUILDER } \\
\text { Category }\end{array}$ & $\begin{array}{l}\text { BUILDER Sub } \\
\text { Issue }\end{array}$ \\
\hline Green & $\begin{array}{l}\text { One of every } 25 \text { parking spaces is } \\
\text { designated for the disabled }\end{array}$ & Accessibility & ABA compliance \\
\hline Green & $\begin{array}{l}\text { The 1:25 standard does not have to be met, } \\
\text { but spaces should be provided for disabled } \\
\text { personnel and visitors to facility }\end{array}$ & Accessibility & ABA compliance \\
\hline Green & $\begin{array}{l}\text { Accessible parking spaces are at least } 8 \text { feet } \\
\text { wide and have } 5 \text { additional feet for exiting } \\
\text { the car }\end{array}$ & Accessibility & ABA compliance \\
\hline Green & $\begin{array}{l}\text { Disabled parking is near the shortest } \\
\text { possible route to an accessible entrance }\end{array}$ & Accessibility & ABA compliance \\
\hline Green & Accessible spaces are designated with signs & Accessibility & ABA compliance \\
\hline Green & $\begin{array}{l}\text { Curb ramps are available wherever an } \\
\text { accessible route crosses a curb at a rise of } \\
1: 12 \text { or less }\end{array}$ & Accessibility & ABA compliance \\
\hline Green & $\begin{array}{l}\text { Ramps are available for disabled parking, as } \\
\text { needed, with maximum rise of } 1: 12\end{array}$ & Accessibility & ABA compliance \\
\hline
\end{tabular}




\begin{tabular}{|c|c|c|c|}
\hline Amber & $\begin{array}{l}\text { Meets } 1 \text { of the first two criteria in the Green } \\
\text { column, depending on facility use }\end{array}$ & Accessibility & ABA compliance \\
\hline Amber & For both kinds of facilities: & Accessibility & ABA compliance \\
\hline Amber & $\begin{array}{l}\text { Accessible parking spaces are at least } 8 \text { feet } \\
\text { wide and have } 5 \text { additional feet for exiting } \\
\text { the car }\end{array}$ & Accessibility & ABA compliance \\
\hline Amber & $\begin{array}{l}\text { Meets } 2 \text { or } 3 \text { of the elements outlined in the } \\
\text { Green column }\end{array}$ & Accessibility & ABA compliance \\
\hline Red & $\begin{array}{l}\text { Neither of the first } 2 \text { criteria in the Green } \\
\text { column is met }\end{array}$ & Accessibility & ABA compliance \\
\hline Red & For both kinds of facilities: & Accessibility & ABA compliance \\
\hline Red & $\begin{array}{l}\text { Accessible parking spaces are at less than } 8 \\
\text { feet wide or do not have } 5 \text { additional feet for } \\
\text { exiting the car }\end{array}$ & Accessibility & ABA compliance \\
\hline Red & $\begin{array}{l}\text { Meets } 1 \text { or none of the elements outlined in } \\
\text { the Green Column }\end{array}$ & Accessibility & ABA compliance \\
\hline $\begin{array}{l}\text { ISR-I } \\
\text { Component }\end{array}$ & ISR-I Sub Component & ISR-I Priority & \\
\hline Parking & Parking Availability & High & \\
\hline ISR-I Rating & ISR-I Criteria & $\begin{array}{l}\text { BUILDER } \\
\text { Category }\end{array}$ & $\begin{array}{l}\text { BUILDER Sub } \\
\text { Issue }\end{array}$ \\
\hline Green & $\begin{array}{l}\text { Parking spaces are available on the } \\
\text { installation for all personnel and visitors }\end{array}$ & $\begin{array}{l}\text { Size/Configuratio } \\
\mathrm{n}\end{array}$ & Overcrowding \\
\hline Amber & $\begin{array}{l}\text { Parking spaces are available on the } \\
\text { installation for } 75 \%-99 \% \text { of personnel and } \\
\text { visitors }\end{array}$ & $\begin{array}{l}\text { Size/Configuratio } \\
\mathrm{n}\end{array}$ & Overcrowding \\
\hline Red & $\begin{array}{l}\text { Parking spaces are available on the } \\
\text { installation for less than } 75 \% \text { of personnel } \\
\text { and visitors }\end{array}$ & $\begin{array}{l}\text { Size/Configuratio } \\
\mathrm{n}\end{array}$ & Overcrowding \\
\hline $\begin{array}{l}\text { ISR-I } \\
\text { Component }\end{array}$ & ISR-I Sub Component & ISR-I Priority & \\
\hline Parking & Parking Area Standoff & High & \\
\hline ISR-I Rating & ISR-I Criteria & $\begin{array}{l}\text { BUILDER } \\
\text { Category }\end{array}$ & $\begin{array}{l}\text { BUILDER Sub } \\
\text { Issue }\end{array}$ \\
\hline Green & $\begin{array}{l}\text { Parking spaces are located } 82 \text { feet or more } \\
\text { away from occupied facilities }\end{array}$ & Access & Building Entry \\
\hline Green & $\begin{array}{l}\text { Within controlled perimeters, parking spaces } \\
\text { are located } 33 \text { feet or more away from } \\
\text { occupied facilities }\end{array}$ & Access & Building Entry \\
\hline Red & $\begin{array}{l}\text { Parking spaces are located less than } 82 \text { feet } \\
\text { away from occupied facilities }\end{array}$ & Access & Building Entry \\
\hline Red & $\begin{array}{l}\text { Within controlled perimeters, parking spaces } \\
\text { are located less than } 33 \text { feet from occupied } \\
\text { facilities }\end{array}$ & Access & Building Entry \\
\hline $\begin{array}{l}\text { ISR-I } \\
\text { Component }\end{array}$ & ISR-I Sub Component & ISR-I Priority & \\
\hline Parking & Parking Area Lighting & Medium & \\
\hline ISR-I Rating & ISR-I Criteria & $\begin{array}{l}\text { BUILDER } \\
\text { Category }\end{array}$ & $\begin{array}{l}\text { BUILDER Sub } \\
\text { Issue }\end{array}$ \\
\hline
\end{tabular}




\begin{tabular}{|c|c|c|c|}
\hline Green & $\begin{array}{l}\text { Provides direct or area lighting for :Traffic } \\
\text { flow during low visibility }\end{array}$ & Access & Building Entry \\
\hline Green & $\begin{array}{l}\text { Provides direct or area lighting for: } \\
\text { Pedestrian movement }\end{array}$ & Access & Building Entry \\
\hline Green & Provides direct or area lighting for: Signage & Access & Building Entry \\
\hline Amber & $\begin{array}{l}\text { Not more than } 1 \text { of the } 3 \text { types of lighting in } \\
\text { the Green column is missing }\end{array}$ & Access & Building Entry \\
\hline Red & $\begin{array}{l}\text { More than } 1 \text { of the } 3 \text { types of lighting in the } \\
\text { Green column is missing }\end{array}$ & Access & Building Entry \\
\hline $\begin{array}{l}\text { ISR-I } \\
\text { Component }\end{array}$ & ISR-I Sub Component & ISR-I Priority & \\
\hline Parking & Parking Spaces & Medium & \\
\hline ISR-I Rating & ISR-I Criteria & $\begin{array}{l}\text { BUILDER } \\
\text { Category }\end{array}$ & $\begin{array}{l}\text { BUILDER Sub } \\
\text { Issue }\end{array}$ \\
\hline Green & Spaces marked on pavement & Aesthetics & $\begin{array}{l}\text { Exterior } \\
\text { Aesthetics }\end{array}$ \\
\hline Green & Sized 8.5 feet wide by $16-18$ feet long & Aesthetics & $\begin{array}{l}\text { Exterior } \\
\text { Aesthetics }\end{array}$ \\
\hline Amber & $\begin{array}{l}\text { Spaces marked on pavement, but re- } \\
\text { stripping is needed }\end{array}$ & Aesthetics & $\begin{array}{l}\text { Exterior } \\
\text { Aesthetics }\end{array}$ \\
\hline Red & Spaces not identified & Aesthetics & $\begin{array}{l}\text { Exterior } \\
\text { Aesthetics }\end{array}$ \\
\hline Red & Less than 8.5 wide by $16-18$ long & Aesthetics & $\begin{array}{l}\text { Exterior } \\
\text { Aesthetics }\end{array}$ \\
\hline $\begin{array}{l}\text { ISR-I } \\
\text { Component }\end{array}$ & ISR-I Sub Component & ISR-I Priority & \\
\hline Parking & Parking Landscaping & Low & \\
\hline ISR-I Rating & ISR-I Criteria & $\begin{array}{l}\text { BUILDER } \\
\text { Category }\end{array}$ & $\begin{array}{l}\text { BUILDER Sub } \\
\text { Issue }\end{array}$ \\
\hline Green & $\begin{array}{l}\text { Displays a mixture of colorful plants and } \\
\text { greenery appropriate to the area }\end{array}$ & Aesthetics & $\begin{array}{l}\text { Exterior } \\
\text { Aesthetics }\end{array}$ \\
\hline Amber & Displays few plantings of color and greenery & Aesthetics & $\begin{array}{l}\text { Exterior } \\
\text { Aesthetics }\end{array}$ \\
\hline Red & No plantings & Aesthetics & $\begin{array}{l}\text { Exterior } \\
\text { Aesthetics }\end{array}$ \\
\hline $\begin{array}{l}\text { ISR-I } \\
\text { Component }\end{array}$ & ISR-I Sub Component & ISR-I Priority & \\
\hline Parking & Parking Signage & Low & \\
\hline ISR-I Rating & ISR-I Criteria & $\begin{array}{l}\text { BUILDER } \\
\text { Category }\end{array}$ & $\begin{array}{l}\text { BUILDER Sub } \\
\text { Issue }\end{array}$ \\
\hline Green & $\begin{array}{l}\text { Lot(s) and rows have identity signs and } \\
\text { traffic control signs, all clearly legible }\end{array}$ & Access & $\begin{array}{l}\text { Directional Info } \\
\text { and Signage }\end{array}$ \\
\hline Green & $\begin{array}{l}\text { Signs provide directions from parking areas } \\
\text { along walkways to the facility }\end{array}$ & Access & $\begin{array}{l}\text { Directional Info } \\
\text { and Signage }\end{array}$ \\
\hline Amber & $\begin{array}{l}\text { Limited traffic control and lot/row identity } \\
\text { signs; signs hard to read from vehicles }\end{array}$ & Access & $\begin{array}{l}\text { Directional Info } \\
\text { and Signage }\end{array}$ \\
\hline
\end{tabular}




\begin{tabular}{|c|c|c|c|}
\hline Amber & $\begin{array}{l}\text { Signs providing directions from parking } \\
\text { areas along walkways to the facility are not } \\
\text { current or are illegible }\end{array}$ & Access & $\begin{array}{l}\text { Directional Info } \\
\text { and Signage }\end{array}$ \\
\hline \multirow{2}{*}{$\begin{array}{l}\text { Red } \\
\text { Red }\end{array}$} & \multirow{2}{*}{$\begin{array}{l}\text { No traffic control signs, or no lot and row } \\
\text { markings } \\
\text { No signs from parking to the facility }\end{array}$} & \multirow{2}{*}{$\begin{array}{l}\text { Access } \\
\text { Access }\end{array}$} & $\begin{array}{l}\text { Directional Info } \\
\text { and Signage }\end{array}$ \\
\hline & & & $\begin{array}{l}\text { Directional Info } \\
\text { and Signage }\end{array}$ \\
\hline $\begin{array}{l}\text { ISR-I } \\
\text { Component }\end{array}$ & ISR-I Sub Component & ISR-I Priority & \\
\hline $\begin{array}{l}\text { Building } \\
\text { Exterior } \\
\text { General }\end{array}$ & Outside Drainage & High & \\
\hline ISR-I Rating & ISR-I Criteria & $\begin{array}{l}\text { BUILDER } \\
\text { Category }\end{array}$ & $\begin{array}{l}\text { BUILDER Sub } \\
\text { Issue }\end{array}$ \\
\hline Green & Outflow drains away from the building & Drainage & \\
\hline Amber & $\begin{array}{l}\text { Outflow ponds at the building base around } \\
\text { splash blocks }\end{array}$ & Drainage & \\
\hline Red & $\begin{array}{l}\text { Outflow ponds at building base; no splash } \\
\text { blocks }\end{array}$ & Drainage & \\
\hline $\begin{array}{l}\text { ISR-I } \\
\text { Component }\end{array}$ & ISR-I Sub Component & ISR-I Priority & \\
\hline $\begin{array}{l}\text { Building } \\
\text { Exterior } \\
\text { General }\end{array}$ & Exterior Lighting & High & \\
\hline ISR-I Rating & ISR-I Criteria & $\begin{array}{l}\text { BUILDER } \\
\text { Category }\end{array}$ & $\begin{array}{l}\text { BUILDER Sub } \\
\text { Issue }\end{array}$ \\
\hline Green & Security & Access & Building Entry \\
\hline Green & Pedestrian movement & Access & Building Entry \\
\hline Green & Safety and exit routes & Access & Building Entry \\
\hline Green & General Exterior & Access & Building Entry \\
\hline Amber & $\begin{array}{l}\text { Not more than } 1 \text { of the } 4 \text { types of lighting in } \\
\text { the Green Column is missing }\end{array}$ & Access & Building Entry \\
\hline Red & $\begin{array}{l}\text { Two or more of the } 4 \text { types of lighting in the } \\
\text { Green Column are missing }\end{array}$ & Access & Building Entry \\
\hline $\begin{array}{l}\text { ISR-I } \\
\text { Component }\end{array}$ & ISR-I Sub Component & ISR-I Priority & \\
\hline $\begin{array}{l}\text { Building } \\
\text { Exterior } \\
\text { General }\end{array}$ & Disabled Access & High & \\
\hline ISR-I Rating & ISR-I Criteria & $\begin{array}{l}\text { BUILDER } \\
\text { Category }\end{array}$ & $\begin{array}{l}\text { BUILDER Sub } \\
\text { Issue }\end{array}$ \\
\hline Green & $\begin{array}{l}\text { At least } 1 \text { main entry door allows disabled } \\
\text { access to each public or work space area } \\
\text { within the building }\end{array}$ & Accessibility & ABA compliance \\
\hline Green & $\begin{array}{l}\text { At entries with doors in series, clearances } \\
\text { for the disabled are } 48 \text { inches clear of any } \\
\text { door swing }\end{array}$ & Accessibility & ABA compliance \\
\hline Green & $\begin{array}{l}\text { Next to any revolving door there is a single } \\
\text { leaf door for the disabled }\end{array}$ & Accessibility & ABA compliance \\
\hline
\end{tabular}




\begin{tabular}{|c|c|c|c|}
\hline Green & $\begin{array}{l}\text { A service entry is not the sole disabled } \\
\text { accessible entry, unless it is the only entry }\end{array}$ & Accessibility & ABA compliance \\
\hline Green & $\begin{array}{l}\text { Accessible exit door connects to bus stops, } \\
\text { disabled parking/loading zones, and public } \\
\text { streets by an accessible route }\end{array}$ & Accessibility & ABA compliance \\
\hline Amber & $\begin{array}{l}3 \text { or more of the } 5 \text { conditions in the Green } \\
\text { column are met }\end{array}$ & Accessibility & ABA compliance \\
\hline Red & $\begin{array}{l}\text { Less than } 3 \text { of the } 5 \text { conditions in the Green } \\
\text { column are met }\end{array}$ & Accessibility & ABA compliance \\
\hline Red & Building is inaccessible to the disabled & Accessibility & ABA compliance \\
\hline $\begin{array}{l}\text { ISR-I } \\
\text { Component }\end{array}$ & ISR-I Sub Component & ISR-I Priority & \\
\hline $\begin{array}{l}\text { Building } \\
\text { Exterior } \\
\text { General }\end{array}$ & Building Exterior Signage & Medium & \\
\hline ISR-I Rating & ISR-I Criteria & $\begin{array}{l}\text { BUILDER } \\
\text { Category }\end{array}$ & $\begin{array}{l}\text { BUILDER Sub } \\
\text { Issue }\end{array}$ \\
\hline Green & Coordinated, clearly visible, and readable & Access & $\begin{array}{l}\text { Directional Info } \\
\text { and Signage }\end{array}$ \\
\hline Green & $\begin{array}{l}\text { Includes directions to parking, entrances, } \\
\text { and facilities }\end{array}$ & Access & $\begin{array}{l}\text { Directional Info } \\
\text { and Signage }\end{array}$ \\
\hline Green & Information is current & Access & $\begin{array}{l}\text { Directional Info } \\
\text { and Signage }\end{array}$ \\
\hline Amber & Not well coordinated but readable & Access & $\begin{array}{l}\text { Directional Info } \\
\text { and Signage }\end{array}$ \\
\hline Amber & $\begin{array}{l}\text { Missing directories to parking, entrances, or } \\
\text { facilities }\end{array}$ & Access & $\begin{array}{l}\text { Directional Info } \\
\text { and Signage }\end{array}$ \\
\hline Red & In very poor condition; not visible or legible & Access & $\begin{array}{l}\text { Directional Info } \\
\text { and Signage }\end{array}$ \\
\hline Red & Directions not available & Access & $\begin{array}{l}\text { Directional Info } \\
\text { and Signage }\end{array}$ \\
\hline Red & Information is not current & Access & $\begin{array}{l}\text { Directional Info } \\
\text { and Signage }\end{array}$ \\
\hline $\begin{array}{l}\text { ISR-I } \\
\text { Component }\end{array}$ & ISR-I Sub Component & ISR-I Priority & \\
\hline $\begin{array}{l}\text { Building } \\
\text { Exterior } \\
\text { General }\end{array}$ & Mechanical Equipment & Low & \\
\hline ISR-I Rating & ISR-I Criteria & $\begin{array}{l}\text { BUILDER } \\
\text { Category }\end{array}$ & $\begin{array}{l}\text { BUILDER Sub } \\
\text { Issue }\end{array}$ \\
\hline Green & $\begin{array}{l}\text { Screened and painted to match the building } \\
\text { design }\end{array}$ & Aesthetics & $\begin{array}{l}\text { Exterior } \\
\text { Aesthetics }\end{array}$ \\
\hline Amber & $\begin{array}{l}\text { Unscreened, but painted to match the } \\
\text { building color }\end{array}$ & Aesthetics & $\begin{array}{l}\text { Exterior } \\
\text { Aesthetics }\end{array}$ \\
\hline Red & $\begin{array}{l}\text { Unscreened, but not painted to match the } \\
\text { building color }\end{array}$ & Aesthetics & $\begin{array}{l}\text { Exterior } \\
\text { Aesthetics }\end{array}$ \\
\hline $\begin{array}{l}\text { ISR-I } \\
\text { Component }\end{array}$ & ISR-I Sub Component & ISR-I Priority & \\
\hline
\end{tabular}




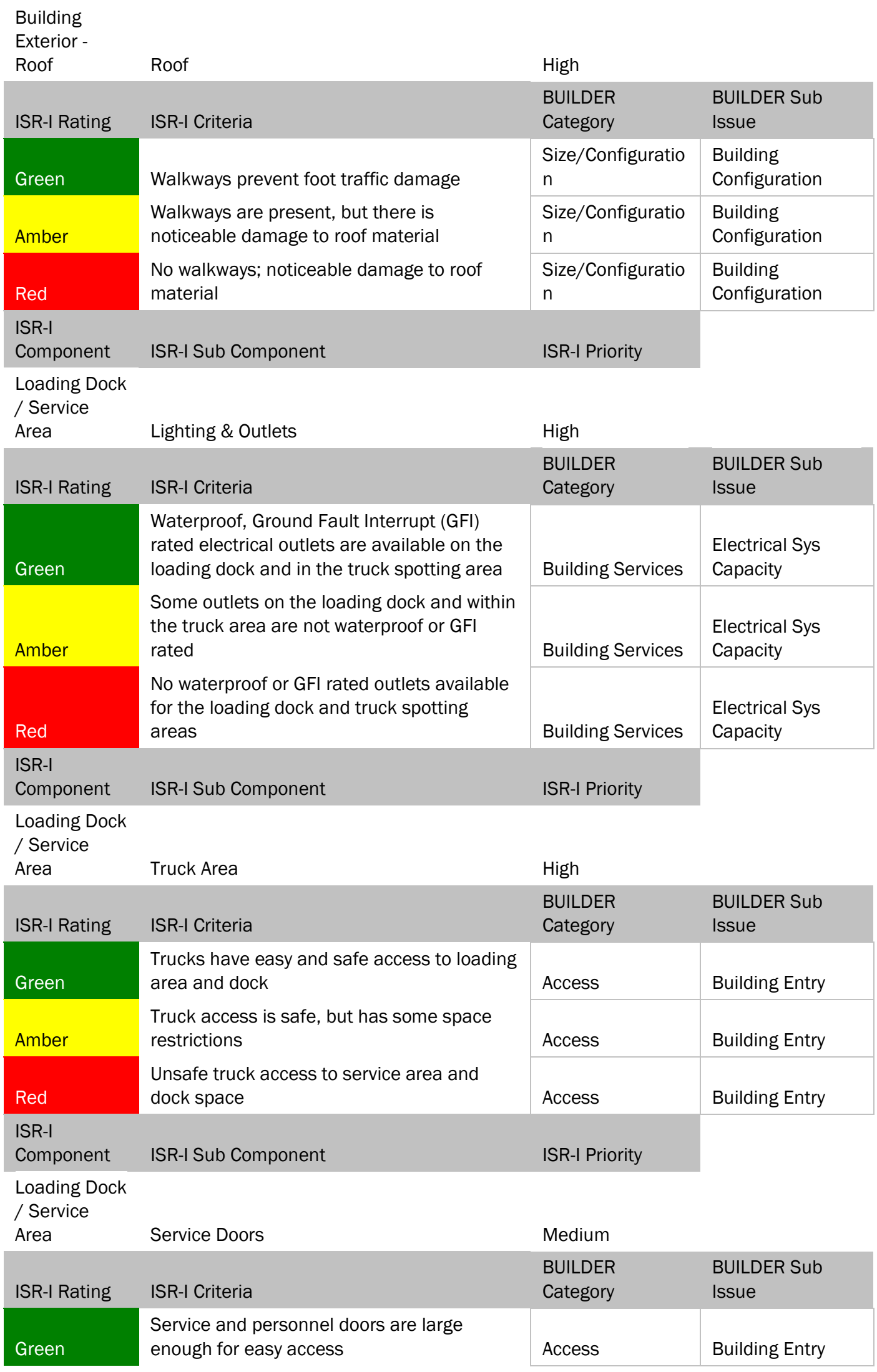




\begin{tabular}{|c|c|c|c|}
\hline Amber & \multirow{2}{*}{$\begin{array}{l}\text { Service and personnel doors provide limited } \\
\text { access } \\
\text { Service and personnel doors provide } \\
\text { inadequate access }\end{array}$} & Access & Building Entry \\
\hline Red & & Access & Building Entry \\
\hline $\begin{array}{l}\text { ISR-I } \\
\text { Component }\end{array}$ & ISR-I Sub Component & ISR-I Priority & \\
\hline $\begin{array}{l}\text { Loading Dock } \\
\text { / Service } \\
\text { Area }\end{array}$ & Dock Boards \& Station Lifts & Medium & \\
\hline ISR-I Rating & ISR-I Criteria & $\begin{array}{l}\text { BUILDER } \\
\text { Category }\end{array}$ & $\begin{array}{l}\text { BUILDER Sub } \\
\text { Issue }\end{array}$ \\
\hline \multirow[t]{2}{*}{ Green } & \multirow{2}{*}{$\begin{array}{l}\text { Loading dock is sized to meet mission } \\
\text { requirements } \\
\text { If required, station lifts are available and } \\
\text { working }\end{array}$} & $\begin{array}{l}\text { Size/Configuratio } \\
n\end{array}$ & $\begin{array}{l}\text { Building } \\
\text { Configuration }\end{array}$ \\
\hline & & $\begin{array}{l}\text { Size/Configuratio } \\
\mathrm{n}\end{array}$ & $\begin{array}{l}\text { Building } \\
\text { Configuration }\end{array}$ \\
\hline \multirow[t]{2}{*}{ Amber } & \multirow{2}{*}{$\begin{array}{l}\text { Loading dock exists, but is not sized to meet } \\
\text { mission needs } \\
\text { If required, station lifts are present, but not } \\
\text { working }\end{array}$} & $\begin{array}{l}\text { Size/Configuratio } \\
\mathrm{n}\end{array}$ & $\begin{array}{l}\text { Building } \\
\text { Configuration }\end{array}$ \\
\hline & & $\begin{array}{l}\text { Size/Configuratio } \\
n\end{array}$ & $\begin{array}{l}\text { Building } \\
\text { Configuration }\end{array}$ \\
\hline \multirow[t]{2}{*}{ Red } & \multirow{2}{*}{$\begin{array}{l}\text { No loading dock exists, although one is } \\
\text { required } \\
\text { Station lifts, if required, are not available }\end{array}$} & $\begin{array}{l}\text { Size/Configuratio } \\
n\end{array}$ & $\begin{array}{l}\text { Building } \\
\text { Configuration }\end{array}$ \\
\hline & & $\begin{array}{l}\text { Size/Configuratio } \\
\mathrm{n}\end{array}$ & $\begin{array}{l}\text { Building } \\
\text { Configuration }\end{array}$ \\
\hline $\begin{array}{l}\text { ISR-I } \\
\text { Component }\end{array}$ & ISR-I Sub Component & ISR-I Priority & \multirow[b]{3}{*}{$\begin{array}{l}\text { BUILDER Sub } \\
\text { Issue }\end{array}$} \\
\hline $\begin{array}{l}\text { Loading Dock } \\
\text { / Service } \\
\text { Area }\end{array}$ & Signage & Medium & \\
\hline ISR-I Rating & ISR-I Criteria & $\begin{array}{l}\text { BUILDER } \\
\text { Category }\end{array}$ & \\
\hline Green & Present and current & Access & $\begin{array}{l}\text { Directional Info } \\
\text { and Signage }\end{array}$ \\
\hline Amber & \multirow[t]{2}{*}{ Present, but not current } & Access & $\begin{array}{l}\text { Directional Info } \\
\text { and Signage }\end{array}$ \\
\hline Red & & Access & $\begin{array}{l}\text { Directional Info } \\
\text { and Signage }\end{array}$ \\
\hline \multicolumn{3}{|l|}{ ISR-I } & \\
\hline \multicolumn{2}{|l|}{$\begin{array}{l}\text { Loading Dock } \\
\text { / Service }\end{array}$} & Low & \\
\hline ISR-I Rating & ISR-I Criteria & $\begin{array}{l}\text { BUILDER } \\
\text { Category }\end{array}$ & $\begin{array}{l}\text { BUILDER Sub } \\
\text { Issue }\end{array}$ \\
\hline Green & $\begin{array}{l}\text { Bollards (posts) protect dock walls, corners } \\
\text { and doorways from Material Handling } \\
\text { Equipment (MHE) }\end{array}$ & $\begin{array}{l}\text { Size/Configuratio } \\
n\end{array}$ & $\begin{array}{l}\text { Building } \\
\text { Configuration }\end{array}$ \\
\hline Amber & $\begin{array}{l}\text { Bollards are in place, but do not protect } \\
\text { dock walls, corners, and/or doorways }\end{array}$ & $\begin{array}{l}\text { Size/Configuratio } \\
\mathrm{n}\end{array}$ & $\begin{array}{l}\text { Building } \\
\text { Configuration }\end{array}$ \\
\hline Red & Bollards need to be replaced or are missing & $\begin{array}{l}\text { Size/Configuratio } \\
\mathrm{n}\end{array}$ & $\begin{array}{l}\text { Building } \\
\text { Configuration }\end{array}$ \\
\hline
\end{tabular}




\begin{tabular}{|c|c|c|c|}
\hline $\begin{array}{l}\text { ISR-I } \\
\text { Component }\end{array}$ & ISR-I Sub Component & ISR-I Priority & \\
\hline Lobby & Lobby Area & High & \\
\hline ISR-I Rating & ISR-I Criteria & $\begin{array}{l}\text { BUILDER } \\
\text { Category }\end{array}$ & $\begin{array}{l}\text { BUILDER Sub } \\
\text { Issue }\end{array}$ \\
\hline Green & Space layout meets mission needs & $\begin{array}{l}\text { Size/Configuratio } \\
\mathrm{n}\end{array}$ & $\begin{array}{l}\text { Building } \\
\text { Configuration }\end{array}$ \\
\hline Amber & $\begin{array}{l}\text { Space layout restricts movement in lobby or } \\
\text { restricts mission needs }\end{array}$ & $\begin{array}{l}\text { Size/Configuratio } \\
\mathrm{n}\end{array}$ & $\begin{array}{l}\text { Building } \\
\text { Configuration }\end{array}$ \\
\hline Red & $\begin{array}{l}\text { Space layout is inadequate to fulfill mission } \\
\text { needs }\end{array}$ & $\begin{array}{l}\text { Size/Configuratio } \\
\mathrm{n}\end{array}$ & $\begin{array}{l}\text { Building } \\
\text { Configuration }\end{array}$ \\
\hline $\begin{array}{l}\text { ISR-I } \\
\text { Component }\end{array}$ & ISR-I Sub Component & ISR-I Priority & \\
\hline Lobby & Lighting \& Outlets & High & \\
\hline ISR-I Rating & ISR-I Criteria & $\begin{array}{l}\text { BUILDER } \\
\text { Category }\end{array}$ & $\begin{array}{l}\text { BUILDER Sub } \\
\text { Issue }\end{array}$ \\
\hline Green & $\begin{array}{l}\text { At least one electrical duplex outlet (three } \\
\text { prong grounded) on all wall surfaces }\end{array}$ & Building Services & $\begin{array}{l}\text { Electrical Sys } \\
\text { Capacity }\end{array}$ \\
\hline Amber & $\begin{array}{l}\text { One or more walls lack grounded duplex } \\
\text { outlets }\end{array}$ & Building Services & $\begin{array}{l}\text { Electrical Sys } \\
\text { Capacity }\end{array}$ \\
\hline Red & No grounded duplex outlets in lobby & Building Services & $\begin{array}{l}\text { Electrical Sys } \\
\text { Capacity }\end{array}$ \\
\hline $\begin{array}{l}\text { ISR-I } \\
\text { Component }\end{array}$ & ISR-I Sub Component & ISR-I Priority & \\
\hline Lobby & Signage & High & \\
\hline ISR-I Rating & ISR-I Criteria & $\begin{array}{l}\text { BUILDER } \\
\text { Category }\end{array}$ & $\begin{array}{l}\text { BUILDER Sub } \\
\text { Issue }\end{array}$ \\
\hline Green & $\begin{array}{l}\text { Present and current; includes a building } \\
\text { directory }\end{array}$ & Access & $\begin{array}{l}\text { Directional Info } \\
\text { and Signage }\end{array}$ \\
\hline Amber & $\begin{array}{l}\text { Present, but not current; does not include a } \\
\text { building directory }\end{array}$ & Access & $\begin{array}{l}\text { Directional Info } \\
\text { and Signage }\end{array}$ \\
\hline Red & No present & Access & $\begin{array}{l}\text { Directional Info } \\
\text { and Signage }\end{array}$ \\
\hline $\begin{array}{l}\text { ISR-I } \\
\text { Component }\end{array}$ & ISR-I Sub Component & ISR-I Priority & \\
\hline Lobby & Interior Doors & Medium & \\
\hline ISR-I Rating & ISR-I Criteria & $\begin{array}{l}\text { BUILDER } \\
\text { Category }\end{array}$ & $\begin{array}{l}\text { BUILDER Sub } \\
\text { Issue }\end{array}$ \\
\hline Green & $\begin{array}{l}\text { Allow access by the disabled to public or } \\
\text { work spaces in the facility }\end{array}$ & Accessibility & ABA compliance \\
\hline Green & $\begin{array}{l}\text { Interior doors that are also fire/exit doors, } \\
\text { and normally in an open position, are } \\
\text { equipped with automatic closure devices } \\
\text { and panic hardware }\end{array}$ & $\begin{array}{l}\text { Environment/Life } \\
\text { Safety }\end{array}$ & $\begin{array}{l}\text { Fire/Smoke } \\
\text { Detection }\end{array}$ \\
\hline Green & $\begin{array}{l}\text { Panic hardware does not require a key or } \\
\text { special tools to open from inside }\end{array}$ & $\begin{array}{l}\text { Environment/Life } \\
\text { Safety }\end{array}$ & $\begin{array}{l}\text { Fire/Smoke } \\
\text { Detection }\end{array}$ \\
\hline Red & $\begin{array}{l}\text { Do not allow access by the disabled to } \\
\text { public or work spaces in the facility }\end{array}$ & Accessibility & ABA compliance \\
\hline
\end{tabular}




\begin{tabular}{|c|c|c|c|}
\hline Red & $\begin{array}{l}\text { Interior doors that are also fire/exit doors, } \\
\text { and normally in an open position, are not } \\
\text { equipped with automatic closure devices } \\
\text { and/or panic hardware }\end{array}$ & $\begin{array}{l}\text { Environment/Life } \\
\text { Safety }\end{array}$ & $\begin{array}{l}\text { Fire/Smoke } \\
\text { Detection }\end{array}$ \\
\hline Red & $\begin{array}{l}\text { Panic hardware requires a key or special } \\
\text { tools to open from inside }\end{array}$ & $\begin{array}{l}\text { Environment/Life } \\
\text { Safety }\end{array}$ & $\begin{array}{l}\text { Fire/Smoke } \\
\text { Detection }\end{array}$ \\
\hline $\begin{array}{l}\text { ISR-I } \\
\text { Component }\end{array}$ & ISR-I Sub Component & ISR-I Priority & \\
\hline Lobby & Telephone System & Medium & \\
\hline ISR-I Rating & ISR-I Criteria & $\begin{array}{l}\text { BUILDER } \\
\text { Category }\end{array}$ & $\begin{array}{l}\text { BUILDER Sub } \\
\text { Issue }\end{array}$ \\
\hline Green & $\begin{array}{l}\text { Enough telephone jacks are available to } \\
\text { support current mission requirements }\end{array}$ & Building Services & $\begin{array}{l}\text { Telephone } \\
\text { System }\end{array}$ \\
\hline Amber & Not enough telephone jacks are available & Building Services & $\begin{array}{l}\text { Telephone } \\
\text { System }\end{array}$ \\
\hline Red & If required, telephone jacks are not available & Building Services & $\begin{array}{l}\text { Telephone } \\
\text { System }\end{array}$ \\
\hline $\begin{array}{l}\text { ISR-I } \\
\text { Component }\end{array}$ & ISR-I Sub Component & ISR-I Priority & \\
\hline Lobby & Computer LAN System & Medium & \\
\hline ISR-I Rating & ISR-I Criteria & $\begin{array}{l}\text { BUILDER } \\
\text { Category }\end{array}$ & $\begin{array}{l}\text { BUILDER Sub } \\
\text { Issue }\end{array}$ \\
\hline Green & $\begin{array}{l}\text { Enough LAN outlets are available to support } \\
\text { mission requirements }\end{array}$ & Building Services & $\begin{array}{l}\text { Building IT } \\
\text { System }\end{array}$ \\
\hline Amber & Not enough LAN outlets are available & Building Services & $\begin{array}{l}\text { Building IT } \\
\text { System }\end{array}$ \\
\hline Red & If required, LAN outlets are not available & Building Services & $\begin{array}{l}\text { Building IT } \\
\text { System }\end{array}$ \\
\hline $\begin{array}{l}\text { ISR-I } \\
\text { Component }\end{array}$ & ISR-I Sub Component & ISR-I Priority & \\
\hline Corridors & Corridor Transit Area & High & \\
\hline ISR-I Rating & ISR-I Criteria & $\begin{array}{l}\text { BUILDER } \\
\text { Category }\end{array}$ & $\begin{array}{l}\text { BUILDER Sub } \\
\text { Issue }\end{array}$ \\
\hline Green & Minimum of 4 feet wide & $\begin{array}{l}\text { Size/Configuratio } \\
\mathrm{n}\end{array}$ & $\begin{array}{l}\text { Building } \\
\text { Configuration }\end{array}$ \\
\hline Green & Fire extinguishers in secure boxes & $\begin{array}{l}\text { Size/Configuratio } \\
\mathrm{n}\end{array}$ & $\begin{array}{l}\text { Building } \\
\text { Configuration }\end{array}$ \\
\hline Amber & Corridors meet 2 of the 3 bulleted elements & $\begin{array}{l}\text { Size/Configuratio } \\
\mathrm{n}\end{array}$ & $\begin{array}{l}\text { Building } \\
\text { Configuration }\end{array}$ \\
\hline Red & $\begin{array}{l}\text { Less than } 2 \text { of the bulleted elements in the } \\
\text { Green column are met }\end{array}$ & $\begin{array}{l}\text { Size/Configuratio } \\
\mathrm{n}\end{array}$ & $\begin{array}{l}\text { Building } \\
\text { Configuration }\end{array}$ \\
\hline $\begin{array}{l}\text { ISR-I } \\
\text { Component }\end{array}$ & ISR-I Sub Component & ISR-I Priority & \\
\hline Corridors & Lighting \& Outlets & High & \\
\hline ISR-I Rating & ISR-I Criteria & $\begin{array}{l}\text { BUILDER } \\
\text { Category }\end{array}$ & $\begin{array}{l}\text { BUILDER Sub } \\
\text { Issue }\end{array}$ \\
\hline Green & $\begin{array}{l}\text { At least one electrical duplex (three prong } \\
\text { grounded) outlet on all wall surfaces }\end{array}$ & Building Services & $\begin{array}{l}\text { Electrical Sys } \\
\text { Capacity }\end{array}$ \\
\hline
\end{tabular}




\begin{tabular}{|c|c|c|c|}
\hline Amber & $\begin{array}{l}\text { One or more walls lack grounded duplex } \\
\text { outlets }\end{array}$ & Building Services & $\begin{array}{l}\text { Electrical Sys } \\
\text { Capacity }\end{array}$ \\
\hline Red & No grounded duplex outlets in Lobby, or & Building Services & $\begin{array}{l}\text { Electrical Sys } \\
\text { Capacity }\end{array}$ \\
\hline $\begin{array}{l}\text { ISR-I } \\
\text { Component }\end{array}$ & ISR-I Sub Component & ISR-I Priority & \\
\hline Corridors & Corridor Doors & High & \\
\hline ISR-I Rating & ISR-I Criteria & $\begin{array}{l}\text { BUILDER } \\
\text { Category }\end{array}$ & $\begin{array}{l}\text { BUILDER Sub } \\
\text { Issue }\end{array}$ \\
\hline Green & $\begin{array}{l}\text { Allow access by the disabled to public or } \\
\text { work spaces in the facility }\end{array}$ & Accessibility & ABA compliance \\
\hline Green & $\begin{array}{l}\text { Interior doors that are also fire/exit doors, } \\
\text { and normally in an open position, are } \\
\text { equipped with automatic closure devices } \\
\text { and panic hardware }\end{array}$ & $\begin{array}{l}\text { Environment/Life } \\
\text { Safety }\end{array}$ & $\begin{array}{l}\text { Fire/Smoke } \\
\text { Detection }\end{array}$ \\
\hline Green & $\begin{array}{l}\text { Interior doors that exit to the exterior are } \\
\text { metal or solid core wood and open easily } \\
\text { from the inside }\end{array}$ & Access & Building Entry \\
\hline Green & $\begin{array}{l}\text { Panic hardware does not require a key or } \\
\text { special tools to open from inside. }\end{array}$ & $\begin{array}{l}\text { Environment/Life } \\
\text { Safety }\end{array}$ & $\begin{array}{l}\text { Fire/Smoke } \\
\text { Detection }\end{array}$ \\
\hline Red & $\begin{array}{l}\text { Does not allow access by the disabled to } \\
\text { public or work spaces in the facility }\end{array}$ & Accessibility & ABA compliance \\
\hline Red & $\begin{array}{l}\text { Interior doors that are also fire/exit doors, } \\
\text { and normally in an open position, are not } \\
\text { equipped with automatic closure devices } \\
\text { and/or panic hardware }\end{array}$ & $\begin{array}{l}\text { Environment/Life } \\
\text { Safety }\end{array}$ & $\begin{array}{l}\text { Fire/Smoke } \\
\text { Detection }\end{array}$ \\
\hline Red & $\begin{array}{l}\text { Interior doors that exit to the exterior are not } \\
\text { metal or solid core wood or do not open } \\
\text { easily from the inside }\end{array}$ & Access & Building Entry \\
\hline Red & $\begin{array}{l}\text { Panic hardware requires a key or special } \\
\text { tools to open from inside }\end{array}$ & $\begin{array}{l}\text { Environment/Life } \\
\text { Safety }\end{array}$ & $\begin{array}{l}\text { Fire/Smoke } \\
\text { Detection }\end{array}$ \\
\hline $\begin{array}{l}\text { ISR-I } \\
\text { Component }\end{array}$ & ISR-I Sub Component & ISR-I Priority & \\
\hline Stairs & Stair Doors & High & \\
\hline ISR-I Rating & ISR-I Criteria & $\begin{array}{l}\text { BUILDER } \\
\text { Category }\end{array}$ & $\begin{array}{l}\text { BUILDER Sub } \\
\text { Issue }\end{array}$ \\
\hline Green & $\begin{array}{l}\text { Panic hardware does not require key or } \\
\text { special tools to operate from inside }\end{array}$ & $\begin{array}{l}\text { Environment/Life } \\
\text { Safety }\end{array}$ & $\begin{array}{l}\text { Fire/Smoke } \\
\text { Detection }\end{array}$ \\
\hline Red & $\begin{array}{l}\text { Panic hardware requires key or special tools } \\
\text { to operate from inside }\end{array}$ & $\begin{array}{l}\text { Environment/Life } \\
\text { Safety }\end{array}$ & $\begin{array}{l}\text { Fire/Smoke } \\
\text { Detection }\end{array}$ \\
\hline $\begin{array}{l}\text { ISR-I } \\
\text { Component }\end{array}$ & ISR-I Sub Component & ISR-I Priority & \\
\hline Stairs & Lighting and Outlets & High & \\
\hline ISR-I Rating & ISR-I Criteria & $\begin{array}{l}\text { BUILDER } \\
\text { Category }\end{array}$ & $\begin{array}{l}\text { BUILDER Sub } \\
\text { Issue }\end{array}$ \\
\hline Green & $\begin{array}{l}\text { If required, there is at least on GFI outlet at } \\
\text { each floor landing }\end{array}$ & Building Services & $\begin{array}{l}\text { Electrical } \\
\text { Grounding } \\
\text { System }\end{array}$ \\
\hline
\end{tabular}




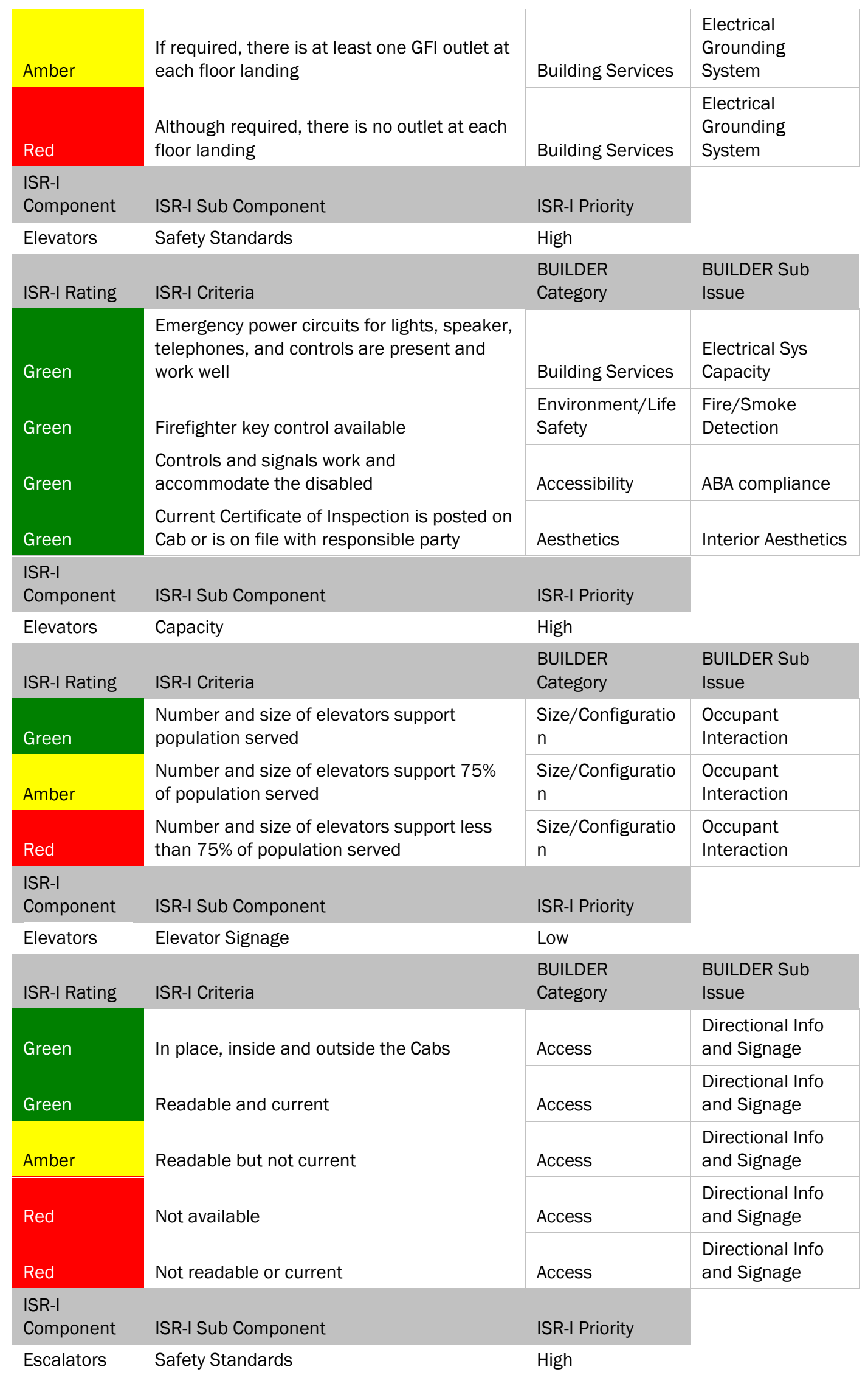




\begin{tabular}{|c|c|c|c|}
\hline ISR-I Rating & ISR-I Criteria & $\begin{array}{l}\text { BUILDER } \\
\text { Category }\end{array}$ & $\begin{array}{l}\text { BUILDER Sub } \\
\text { Issue }\end{array}$ \\
\hline \multirow[t]{2}{*}{ Green } & Width is minimum of 32 inches & $\begin{array}{l}\text { Size/Configuratio } \\
\mathrm{n}\end{array}$ & $\begin{array}{l}\text { Occupant } \\
\text { Interaction }\end{array}$ \\
\hline & \multirow{2}{*}{$\begin{array}{l}\text { Emergency stop controls at the top and } \\
\text { bottom of the escalator work well } \\
\text { Overhead smoke/heat detectors and } \\
\text { sprinkler heads are tied to provide } \\
\text { protection in case of fire }\end{array}$} & $\begin{array}{l}\text { Missing/Im- } \\
\text { proper Comps }\end{array}$ & $\begin{array}{l}\text { Are all the } \\
\text { necessary } \\
\text { components } \\
\text { present? }\end{array}$ \\
\hline Green & & $\begin{array}{l}\text { Environment/Life } \\
\text { Safety }\end{array}$ & $\begin{array}{l}\text { Fire/Smoke } \\
\text { Detection }\end{array}$ \\
\hline \multicolumn{4}{|l|}{ ISR-I } \\
\hline Escalators & Signage & Low & \\
\hline ISR-I Rating & ISR-I Criteria & $\begin{array}{l}\text { BUILDER } \\
\text { Category }\end{array}$ & $\begin{array}{l}\text { BUILDER Sub } \\
\text { Issue }\end{array}$ \\
\hline \multirow[t]{2}{*}{ Green } & Well placed for easy location of escalators & Access & $\begin{array}{l}\text { Directional Info } \\
\text { and Signage }\end{array}$ \\
\hline & Highly visible and readable & Access & $\begin{array}{l}\text { Directional Info } \\
\text { and Signage }\end{array}$ \\
\hline \multirow[t]{2}{*}{ Amber } & Signage is available, but not well placed & Access & $\begin{array}{l}\text { Directional Info } \\
\text { and Signage }\end{array}$ \\
\hline & \multirow[t]{2}{*}{ Hard to read } & Access & $\begin{array}{l}\text { Directional Info } \\
\text { and Signage }\end{array}$ \\
\hline Red & & Access & $\begin{array}{l}\text { Directional Info } \\
\text { and Signage }\end{array}$ \\
\hline \multicolumn{4}{|l|}{ ISR-I } \\
\hline \multicolumn{3}{|l|}{ Administrativ } & \\
\hline ISR-I Rating & ISR-I Criteria & $\begin{array}{l}\text { BUILDER } \\
\text { Category }\end{array}$ & $\begin{array}{l}\text { BUILDER Sub } \\
\text { Issue }\end{array}$ \\
\hline Green & \multirow{2}{*}{$\begin{array}{l}\text { Flexible layout; space meets mission needs } \\
\text { Sufficient storage space, close to work } \\
\text { stations, meets mission needs }\end{array}$} & $\begin{array}{l}\text { Size/Configuratio } \\
\mathrm{n}\end{array}$ & $\begin{array}{l}\text { Occupant } \\
\text { Interaction }\end{array}$ \\
\hline Green & & $\begin{array}{l}\text { Size/Configuratio } \\
\mathrm{n}\end{array}$ & $\begin{array}{l}\text { Building } \\
\text { Configuration }\end{array}$ \\
\hline \multirow[t]{2}{*}{ Amber } & \multirow{2}{*}{$\begin{array}{l}\text { Space restricts aisle and workstation layout } \\
\text { Marginal storage space, not close to } \\
\text { workstations, but meets mission needs }\end{array}$} & $\begin{array}{l}\text { Size/Configuratio } \\
\mathrm{n}\end{array}$ & $\begin{array}{l}\text { Occupant } \\
\text { Interaction }\end{array}$ \\
\hline & & $\begin{array}{l}\text { Size/Configuratio } \\
\mathrm{n}\end{array}$ & $\begin{array}{l}\text { Building } \\
\text { Configuration }\end{array}$ \\
\hline \multirow[t]{2}{*}{ Red } & \multirow{2}{*}{$\begin{array}{l}\text { Workstation layout does not meet needs } \\
\text { Little to no storage space; hinders effective } \\
\text { operations }\end{array}$} & $\begin{array}{l}\text { Size/Configuratio } \\
\mathrm{n}\end{array}$ & $\begin{array}{l}\text { Occupant } \\
\text { Interaction }\end{array}$ \\
\hline & & $\begin{array}{l}\text { Size/Configuratio } \\
\mathrm{n}\end{array}$ & $\begin{array}{l}\text { Building } \\
\text { Configuration }\end{array}$ \\
\hline $\begin{array}{l}\text { ISR-I } \\
\text { Component }\end{array}$ & ISR-I Sub Component & ISR-I Priority & \\
\hline $\begin{array}{l}\text { Administrativ } \\
\text { e Areas }\end{array}$ & Lighting and Outlets & High & \\
\hline
\end{tabular}




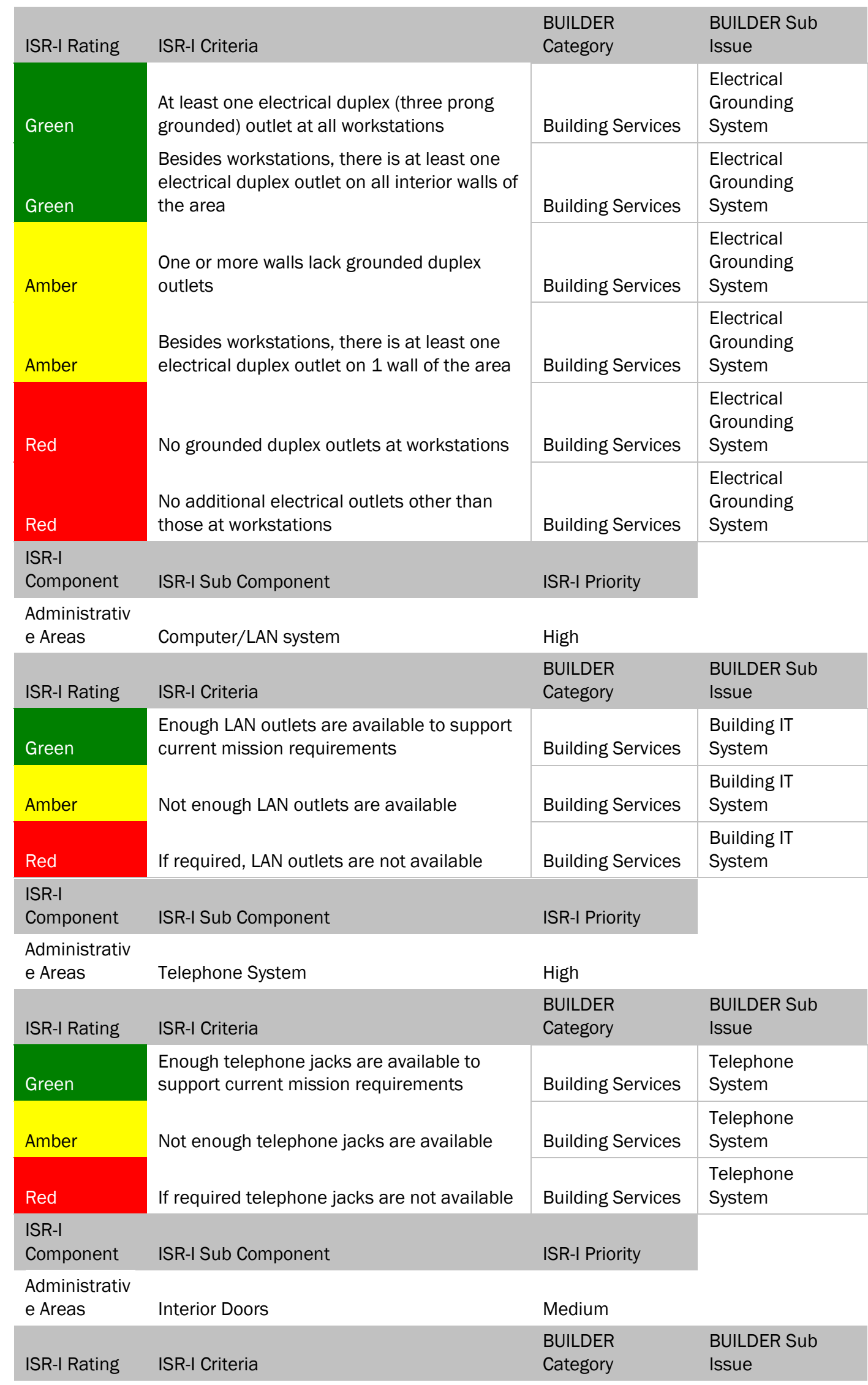




\begin{tabular}{|c|c|c|c|}
\hline Red & $\begin{array}{l}\text { Do not allow access by the disabled to } \\
\text { public or work spaces in the facility }\end{array}$ & Accessibility & ABA compliance \\
\hline Red & $\begin{array}{l}\text { Doors that exit to the exterior are not } \\
\text { equipped with fire/exit signs and panic } \\
\text { hardware }\end{array}$ & $\begin{array}{l}\text { Missing/Im- } \\
\text { proper Comps }\end{array}$ & $\begin{array}{l}\text { Missing } \\
\text { Components? }\end{array}$ \\
\hline $\begin{array}{l}\text { ISR-I } \\
\text { Component }\end{array}$ & ISR-I Sub Component & ISR-I Priority & \\
\hline Bathrooms & Ventilation & High & \\
\hline ISR-I Rating & ISR-I Criteria & $\begin{array}{l}\text { BUILDER } \\
\text { Category }\end{array}$ & $\begin{array}{l}\text { BUILDER Sub } \\
\text { Issue }\end{array}$ \\
\hline Green & Ventilation integrated into forced air system & Comfort & $\begin{array}{l}\text { Ventilation } \\
\text { Capacity }\end{array}$ \\
\hline Amber & $\begin{array}{l}\text { Fans provided, but not integrated into forced } \\
\text { air system }\end{array}$ & Comfort & $\begin{array}{l}\text { Ventilation } \\
\text { Capacity }\end{array}$ \\
\hline Red & Poor or no ventilation & Comfort & $\begin{array}{l}\text { Ventilation } \\
\text { Capacity }\end{array}$ \\
\hline $\begin{array}{l}\text { ISR-I } \\
\text { Component }\end{array}$ & ISR-I Sub Component & ISR-I Priority & \\
\hline Bathrooms & Toilets/Sinks Availability & High & \\
\hline ISR-I Rating & ISR-I Criteria & $\begin{array}{l}\text { BUILDER } \\
\text { Category }\end{array}$ & $\begin{array}{l}\text { BUILDER Sub } \\
\text { Issue }\end{array}$ \\
\hline Green & $\begin{array}{l}\text { Number of stalls, urinals, and sinks satisfy } \\
\text { population served }\end{array}$ & Building Services & Plumbing Fixtures \\
\hline Amber & $\begin{array}{l}\text { Number of stalls, urinals, and sinks support } \\
\text { population served }\end{array}$ & Building Services & Plumbing Fixtures \\
\hline Red & $\begin{array}{l}\text { Number of stalls, urinals, and sinks do not } \\
\text { support population served }\end{array}$ & Building Services & Plumbing Fixtures \\
\hline $\begin{array}{l}\text { ISR-I } \\
\text { Component }\end{array}$ & ISR-I Sub Component & ISR-I Priority & \\
\hline Bathrooms & Disabled Access & High & \\
\hline ISR-I Rating & ISR-I Criteria & $\begin{array}{l}\text { BUILDER } \\
\text { Category }\end{array}$ & $\begin{array}{l}\text { BUILDER Sub } \\
\text { Issue }\end{array}$ \\
\hline $\begin{array}{l}\text { Green } \\
\text { Green }\end{array}$ & $\begin{array}{l}\text { At least one stall is } 56 \times 60 \text { inches, with grab } \\
\text { bars and a } 48 \text {-inch-wide clear approach } \\
\text { At least one sink is mounted no higher than } \\
34 \text { inches off floor, with } 27 \text { inches of clear } \\
\text { space under sink, and } 48 \text { inches clearance } \\
\text { to back out }\end{array}$ & Accessibility & ABA compliance \\
\hline $\begin{array}{l}\text { Amber } \\
\text { Amber }\end{array}$ & $\begin{array}{l}\text { Stall clearances will not allow person in } \\
\text { wheel chair to roll in and close the stall door } \\
\text { Clearances to maneuver are less than } \\
\text { required }\end{array}$ & Accessibility & $\begin{array}{l}\text { ABA compliance } \\
\text { ABA compliance }\end{array}$ \\
\hline Red & No accessibility for the disabled & Accessibility & ABA compliance \\
\hline $\begin{array}{l}\text { ISR-I } \\
\text { Component }\end{array}$ & ISR-I Sub Component & ISR-I Priority & \\
\hline Bathrooms & Lighting and Outlets & High & \\
\hline ISR-I Rating & ISR-I Criteria & $\begin{array}{l}\text { BUILDER } \\
\text { Category }\end{array}$ & $\begin{array}{l}\text { BUILDER Sub } \\
\text { Issue }\end{array}$ \\
\hline
\end{tabular}




\begin{tabular}{|c|c|c|c|}
\hline Green & $\begin{array}{l}\text { All outlets grounded/GFI rated available } \\
\text { where water may be present }\end{array}$ & Building Services & $\begin{array}{l}\text { Electrical Sys } \\
\text { Capacity }\end{array}$ \\
\hline Amber & $\begin{array}{l}\text { All outlets grounded/GFI rated available } \\
\text { where water may be present }\end{array}$ & Building Services & $\begin{array}{l}\text { Electrical Sys } \\
\text { Capacity }\end{array}$ \\
\hline Red & $\begin{array}{l}\text { Underground outlets or outlets where water } \\
\text { may be present are not GFI rated }\end{array}$ & Building Services & $\begin{array}{l}\text { Electrical Sys } \\
\text { Capacity }\end{array}$ \\
\hline $\begin{array}{l}\text { ISR-I } \\
\text { Component }\end{array}$ & ISR-I Sub Component & ISR-I Priority & \\
\hline Bathrooms & Bathroom Accessories & Low & \\
\hline ISR-I Rating & ISR-I Criteria & $\begin{array}{l}\text { BUILDER } \\
\text { Category }\end{array}$ & $\begin{array}{l}\text { BUILDER Sub } \\
\text { Issue }\end{array}$ \\
\hline Green & $\begin{array}{l}\text { Dispensers for hand soap, towels, toilet } \\
\text { paper, disposal containers for hygiene } \\
\text { products, etc., are present and easily } \\
\text { accessible }\end{array}$ & $\begin{array}{l}\text { Missing/Im- } \\
\text { proper Comps }\end{array}$ & $\begin{array}{l}\text { Missing } \\
\text { Components? }\end{array}$ \\
\hline Amber & $\begin{array}{l}\text { Accessories are available, but difficult to } \\
\text { access }\end{array}$ & $\begin{array}{l}\text { Missing/Im- } \\
\text { proper Comps }\end{array}$ & $\begin{array}{l}\text { Missing } \\
\text { Components? }\end{array}$ \\
\hline Red & Accessories are not available & $\begin{array}{l}\text { Missing/Im- } \\
\text { proper Comps }\end{array}$ & $\begin{array}{l}\text { Missing } \\
\text { Components? }\end{array}$ \\
\hline $\begin{array}{l}\text { ISR-I } \\
\text { Component }\end{array}$ & ISR-I Sub Component & ISR-I Priority & \\
\hline $\begin{array}{l}\text { EOC/SCIF } \\
\text { Facility }\end{array}$ & Controlled Access & High & \\
\hline ISR-I Rating & ISR-I Criteria & $\begin{array}{l}\text { BUILDER } \\
\text { Category }\end{array}$ & $\begin{array}{l}\text { BUILDER Sub } \\
\text { Issue }\end{array}$ \\
\hline Green & $\begin{array}{l}\text { Facility configuration and condition supports } \\
\text { effective controlled access }\end{array}$ & $\begin{array}{l}\text { Size/Configuratio } \\
\mathrm{n}\end{array}$ & $\begin{array}{l}\text { Building } \\
\text { Configuration }\end{array}$ \\
\hline Red & $\begin{array}{l}\text { Facility configuration and condition does not } \\
\text { support effective controlled access }\end{array}$ & $\begin{array}{l}\text { Size/Configuratio } \\
\mathrm{n}\end{array}$ & $\begin{array}{l}\text { Building } \\
\text { Configuration }\end{array}$ \\
\hline $\begin{array}{l}\text { ISR-I } \\
\text { Component }\end{array}$ & ISR-I Sub Component & ISR-I Priority & \\
\hline $\begin{array}{l}\text { EOC/SCIF } \\
\text { Facility }\end{array}$ & Space Layout & High & \\
\hline ISR-I Rating & ISR-I Criteria & $\begin{array}{l}\text { BUILDER } \\
\text { Category }\end{array}$ & $\begin{array}{l}\text { BUILDER Sub } \\
\text { Issue }\end{array}$ \\
\hline Green & $\begin{array}{l}\text { Flexible layout meets Sensitive } \\
\text { Compartmented Information Facility (SCIF) } \\
\text { standards }\end{array}$ & $\begin{array}{l}\text { Size/Configuratio } \\
\mathrm{n}\end{array}$ & $\begin{array}{l}\text { Building } \\
\text { Configuration }\end{array}$ \\
\hline Green & $\begin{array}{l}\text { Sufficient storage space, meets SCIF } \\
\text { standards }\end{array}$ & $\begin{array}{l}\text { Size/Configuratio } \\
\mathrm{n}\end{array}$ & $\begin{array}{l}\text { Building } \\
\text { Configuration }\end{array}$ \\
\hline Amber & $\begin{array}{l}\text { Space restricts operations, but meets SCIF } \\
\text { standards }\end{array}$ & $\begin{array}{l}\text { Size/Configuratio } \\
\mathrm{n}\end{array}$ & $\begin{array}{l}\text { Building } \\
\text { Configuration }\end{array}$ \\
\hline Amber & $\begin{array}{l}\text { Marginal storage space, meets SCIF } \\
\text { standards }\end{array}$ & $\begin{array}{l}\text { Size/Configuratio } \\
\mathrm{n}\end{array}$ & $\begin{array}{l}\text { Building } \\
\text { Configuration }\end{array}$ \\
\hline Red & Layout does not meet SCIF standards & $\begin{array}{l}\text { Size/Configuratio } \\
\mathrm{n}\end{array}$ & $\begin{array}{l}\text { Building } \\
\text { Configuration }\end{array}$ \\
\hline Red & $\begin{array}{l}\text { Little to no storage space, does not meet } \\
\text { SCIF Standards }\end{array}$ & $\begin{array}{l}\text { Size/Configuratio } \\
\mathrm{n}\end{array}$ & $\begin{array}{l}\text { Building } \\
\text { Configuration }\end{array}$ \\
\hline
\end{tabular}




\begin{tabular}{|c|c|c|c|}
\hline $\begin{array}{l}\text { ISR-I } \\
\text { Component }\end{array}$ & ISR-I Sub Component & ISR-I Priority & \\
\hline $\begin{array}{l}\text { EOC/SCIF } \\
\text { Facility }\end{array}$ & Telephone System & High & \\
\hline ISR-I Rating & ISR-I Criteria & $\begin{array}{l}\text { BUILDER } \\
\text { Category }\end{array}$ & $\begin{array}{l}\text { BUILDER Sub } \\
\text { Issue }\end{array}$ \\
\hline Green & $\begin{array}{l}\text { Enough telephone jacks are available and } \\
\text { working }\end{array}$ & Building Services & $\begin{array}{l}\text { Telephone } \\
\text { System }\end{array}$ \\
\hline Green & $\begin{array}{l}\text { Telephone system offers security for } \\
\text { classified discussions IAW SCIF area } \\
\text { requirements }\end{array}$ & Building Services & $\begin{array}{l}\text { Telephone } \\
\text { System }\end{array}$ \\
\hline Red & $\begin{array}{l}\text { Not enough telephone jacks and not reliably } \\
\text { working }\end{array}$ & Building Services & $\begin{array}{l}\text { Telephone } \\
\text { System }\end{array}$ \\
\hline Red & $\begin{array}{l}\text { Telephone jacks fail to meet the security } \\
\text { requirements for classified discussions IAW } \\
\text { SCIF standards }\end{array}$ & Building Services & $\begin{array}{l}\text { Telephone } \\
\text { System }\end{array}$ \\
\hline $\begin{array}{l}\text { ISR-I } \\
\text { Component }\end{array}$ & ISR-I Sub Component & ISR-I Priority & \\
\hline $\begin{array}{l}\text { EOC/SCIF } \\
\text { Facility }\end{array}$ & Computer/LAN Systems & High & \\
\hline ISR-I Rating & ISR-I Criteria & $\begin{array}{l}\text { BUILDER } \\
\text { Category }\end{array}$ & $\begin{array}{l}\text { BUILDER Sub } \\
\text { Issue }\end{array}$ \\
\hline Green & Enough LAN outlets available and working & Building Services & $\begin{array}{l}\text { Building IT } \\
\text { System }\end{array}$ \\
\hline Green & $\begin{array}{l}\text { LAN outlets offer security for the exchange } \\
\text { of classified information IAW SCIF standards }\end{array}$ & Building Services & $\begin{array}{l}\text { Building IT } \\
\text { System }\end{array}$ \\
\hline Red & $\begin{array}{l}\text { Not enough LAN outlets available and not } \\
\text { reliably working }\end{array}$ & Building Services & $\begin{array}{l}\text { Building IT } \\
\text { System }\end{array}$ \\
\hline Red & $\begin{array}{l}\text { If available, outlets do not offer the secuirty } \\
\text { level needed to exchange classified } \\
\text { information IAW SCIF standards }\end{array}$ & Building Services & $\begin{array}{l}\text { Building IT } \\
\text { System }\end{array}$ \\
\hline $\begin{array}{l}\text { ISR-I } \\
\text { Component }\end{array}$ & ISR-I Sub Component & ISR-I Priority & \\
\hline $\begin{array}{l}\text { EOC/SCIF } \\
\text { Facility }\end{array}$ & Lighting and Outlets & High & \\
\hline ISR-I Rating & ISR-I Criteria & $\begin{array}{l}\text { BUILDER } \\
\text { Category }\end{array}$ & $\begin{array}{l}\text { BUILDER Sub } \\
\text { Issue }\end{array}$ \\
\hline Green & $\begin{array}{l}\text { Emergency and exit lights work; powered by } \\
\text { emergency power or battery backup }\end{array}$ & Building Services & $\begin{array}{l}\text { Electrical Sys } \\
\text { Capacity }\end{array}$ \\
\hline Amber & $\begin{array}{l}\text { Emergency and exit lights need repairs or } \\
\text { have no emergency or battery backup }\end{array}$ & Building Services & $\begin{array}{l}\text { Electrical Sys } \\
\text { Capacity }\end{array}$ \\
\hline Red & Emergency and exit lights are not in place & Building Services & $\begin{array}{l}\text { Electrical Sys } \\
\text { Capacity }\end{array}$ \\
\hline $\begin{array}{l}\text { ISR-I } \\
\text { Component }\end{array}$ & ISR-I Sub Component & ISR-I Priority & \\
\hline $\begin{array}{l}\text { EOC/SCIF } \\
\text { Facility }\end{array}$ & Ceilings & Medium & \\
\hline ISR-I Rating & ISR-I Criteria & $\begin{array}{l}\text { BUILDER } \\
\text { Category }\end{array}$ & $\begin{array}{l}\text { BUILDER Sub } \\
\text { Issue }\end{array}$ \\
\hline
\end{tabular}




\begin{tabular}{|c|c|c|c|}
\hline Green & Ceilings conform to SCIF requirements & AT/FP & $\begin{array}{l}\text { ATFP } \\
\text { Requirements }\end{array}$ \\
\hline Red & Ceilings do not conform to SCIF standards & AT/FP & $\begin{array}{l}\text { ATFP } \\
\text { Requirements }\end{array}$ \\
\hline $\begin{array}{l}\text { ISR-I } \\
\text { Component }\end{array}$ & ISR-I Sub Component & ISR-I Priority & \\
\hline $\begin{array}{l}\text { EOC/SCIF } \\
\text { Facility }\end{array}$ & Floors & Medium & \\
\hline ISR-I Rating & ISR-I Criteria & $\begin{array}{l}\text { BUILDER } \\
\text { Category }\end{array}$ & $\begin{array}{l}\text { BUILDER Sub } \\
\text { Issue }\end{array}$ \\
\hline Green & Floors conform to SCIF standards & AT/FP & $\begin{array}{l}\text { ATFP } \\
\text { Requirements }\end{array}$ \\
\hline Red & Floors do not conform to SCIF standards & AT/FP & $\begin{array}{l}\text { ATFP } \\
\text { Requirements }\end{array}$ \\
\hline $\begin{array}{l}\text { ISR-I } \\
\text { Component }\end{array}$ & ISR-I Sub Component & ISR-I Priority & \\
\hline $\begin{array}{l}\text { EOC/SCIF } \\
\text { Facility }\end{array}$ & Walls & Medium & \\
\hline ISR-I Rating & ISR-I Criteria & $\begin{array}{l}\text { BUILDER } \\
\text { Category }\end{array}$ & $\begin{array}{l}\text { BUILDER Sub } \\
\text { Issue }\end{array}$ \\
\hline Green & $\begin{array}{l}\text { Walls material and construction meet SCIF } \\
\text { standards }\end{array}$ & AT/FP & $\begin{array}{l}\text { ATFP } \\
\text { Requirements }\end{array}$ \\
\hline Red & $\begin{array}{l}\text { One or more walls materials and } \\
\text { construction fail to meet SCIF standards }\end{array}$ & AT/FP & $\begin{array}{l}\text { ATFP } \\
\text { Requirements }\end{array}$ \\
\hline $\begin{array}{l}\text { ISR-I } \\
\text { Component }\end{array}$ & ISR-I Sub Component & ISR-I Priority & \\
\hline $\begin{array}{l}\text { EOC/SCIF } \\
\text { Facility }\end{array}$ & Doors & Medium & \\
\hline ISR-I Rating & ISR-I Criteria & $\begin{array}{l}\text { BUILDER } \\
\text { Category }\end{array}$ & $\begin{array}{l}\text { BUILDER Sub } \\
\text { Issue }\end{array}$ \\
\hline Green & Doors meet SCIF standards & AT/FP & $\begin{array}{l}\text { ATFP } \\
\text { Requirements }\end{array}$ \\
\hline Red & $\begin{array}{l}\text { One or more doors fail to meet SCIF } \\
\text { standards }\end{array}$ & AT/FP & $\begin{array}{l}\text { ATFP } \\
\text { Requirements }\end{array}$ \\
\hline $\begin{array}{l}\text { ISR-I } \\
\text { Component }\end{array}$ & ISR-I Sub Component & ISR-I Priority & \\
\hline Kitchenette & Plumbing Fixtures & High & \\
\hline ISR-I Rating & ISR-I Criteria & $\begin{array}{l}\text { BUILDER } \\
\text { Category }\end{array}$ & $\begin{array}{l}\text { BUILDER Sub } \\
\text { Issue }\end{array}$ \\
\hline Green & Ample hot water & Building Services & Hot Water Supply \\
\hline Amber & Lukewarm "hot" water & Building Services & Hot Water Supply \\
\hline Red & No hot water & Building Services & Hot Water Supply \\
\hline $\begin{array}{l}\text { ISR-I } \\
\text { Component }\end{array}$ & ISR-I Sub Component & ISR-I Priority & \\
\hline Kitchenette & Cabinets and Countertops & High & \\
\hline ISR-I Rating & ISR-I Criteria & $\begin{array}{l}\text { BUILDER } \\
\text { Category }\end{array}$ & $\begin{array}{l}\text { BUILDER Sub } \\
\text { Issue }\end{array}$ \\
\hline
\end{tabular}




\begin{tabular}{|c|c|c|c|}
\hline Green & Ample space is provided & $\begin{array}{l}\text { Size/Configuratio } \\
\mathrm{n}\end{array}$ & $\begin{array}{l}\text { Building } \\
\text { Configuration }\end{array}$ \\
\hline Red & Inadequate space is provided & $\begin{array}{l}\text { Size/Configuratio } \\
n\end{array}$ & $\begin{array}{l}\text { Building } \\
\text { Configuration }\end{array}$ \\
\hline $\begin{array}{l}\text { ISR-I } \\
\text { Component }\end{array}$ & ISR-I Sub Component & ISR-I Priority & \\
\hline Kitchenette & Appliances & High & \\
\hline ISR-I Rating & ISR-I Criteria & $\begin{array}{l}\text { BUILDER } \\
\text { Category }\end{array}$ & $\begin{array}{l}\text { BUILDER Sub } \\
\text { Issue }\end{array}$ \\
\hline Green & $\begin{array}{l}\text { They include a refrigerator/freezer, a cook- } \\
\text { top and over or microwave }\end{array}$ & $\begin{array}{l}\text { Missing/Im- } \\
\text { proper Comps }\end{array}$ & $\begin{array}{l}\text { Missing } \\
\text { Components? }\end{array}$ \\
\hline Amber & $\begin{array}{l}\text { They include a refrigerator/freezer, a cook- } \\
\text { top and oven or microwave }\end{array}$ & $\begin{array}{l}\text { Missing/Im- } \\
\text { proper Comps }\end{array}$ & $\begin{array}{l}\text { Missing } \\
\text { Components? }\end{array}$ \\
\hline Red & Some standards appliances are missing & $\begin{array}{l}\text { Missing/Im- } \\
\text { proper Comps }\end{array}$ & $\begin{array}{l}\text { Missing } \\
\text { Components? }\end{array}$ \\
\hline $\begin{array}{l}\text { ISR-I } \\
\text { Component }\end{array}$ & ISR-I Sub Component & ISR-I Priority & \\
\hline Kitchenette & Ventilation & Medium & \\
\hline ISR-I Rating & ISR-I Criteria & $\begin{array}{l}\text { BUILDER } \\
\text { Category }\end{array}$ & $\begin{array}{l}\text { BUILDER Sub } \\
\text { Issue }\end{array}$ \\
\hline Green & Ventilation integrated into forced air system & Comfort & $\begin{array}{l}\text { Ventilation } \\
\text { Capacity }\end{array}$ \\
\hline Amber & $\begin{array}{l}\text { Fans provided, but not integrated into forced } \\
\text { air system }\end{array}$ & Comfort & $\begin{array}{l}\text { Ventilation } \\
\text { Capacity }\end{array}$ \\
\hline Red & Poor or no ventilation & Comfort & $\begin{array}{l}\text { Ventilation } \\
\text { Capacity }\end{array}$ \\
\hline $\begin{array}{l}\text { ISR-I } \\
\text { Component }\end{array}$ & ISR-I Sub Component & ISR-I Priority & \\
\hline Bathrooms & Plumbing Fixtures & High & \\
\hline ISR-I Rating & ISR-I Criteria & $\begin{array}{l}\text { BUILDER } \\
\text { Category }\end{array}$ & $\begin{array}{l}\text { BUILDER Sub } \\
\text { Issue }\end{array}$ \\
\hline Green & Ample hot water & Building Services & Hot Water Supply \\
\hline Amber & Lukewarm "hot" water & Building Services & Hot Water Supply \\
\hline Red & No hot water & Building Services & Hot Water Supply \\
\hline
\end{tabular}




\section{Appendix L: Army ISR-I Mapping to BUILDER Functionality Criteria, Maintenance Facilities}

\begin{tabular}{|c|c|c|c|}
\hline $\begin{array}{l}\text { ISR-I } \\
\text { Component }\end{array}$ & ISR-I Sub Component & ISR-I Priority & \\
\hline $\begin{array}{l}\text { Sites and } \\
\text { Grounds }\end{array}$ & Lighting & High & \\
\hline ISR-I Rating & ISR-I Criteria & $\begin{array}{l}\text { BUILDER } \\
\text { Category }\end{array}$ & $\begin{array}{l}\text { BUILDER Sub } \\
\text { Issue }\end{array}$ \\
\hline Green & $\begin{array}{l}\text { Has Lighting for Pedestrian, signage, security, } \\
\text { Landscaping }\end{array}$ & Access & Building Entry \\
\hline Amber & $\begin{array}{l}\text { No more than } 1 \text { of the } 4 \text { types of lighting in Green } \\
\text { column missing }\end{array}$ & Access & Building Entry \\
\hline Red & $\begin{array}{l}\text { Two or more of the } 4 \text { types of lighting in Green } \\
\text { column missing }\end{array}$ & Access & Building Entry \\
\hline Red & No Site and Grounds lighting exists & Access & Building Entry \\
\hline $\begin{array}{l}\text { ISR-I } \\
\text { Component }\end{array}$ & ISR-I Sub Component & ISR-I Priority & \\
\hline $\begin{array}{l}\text { Sites and } \\
\text { Grounds }\end{array}$ & Disabled Access & High & \\
\hline ISR-I Rating & ISR-I Criteria & $\begin{array}{l}\text { BUILDER } \\
\text { Category }\end{array}$ & $\begin{array}{l}\text { BUILDER Sub } \\
\text { Issue }\end{array}$ \\
\hline Green & AccessibilityAG/UFAS accessible walkways & Accessibility & $\begin{array}{l}\text { ABA } \\
\text { compliance }\end{array}$ \\
\hline Green & $\begin{array}{l}\text { Curb ramps are present where accessible routes } \\
\text { cross a curb }\end{array}$ & Accessibility & $\begin{array}{l}\text { ABA } \\
\text { compliance }\end{array}$ \\
\hline Green & Ramps are minimum of 3 feet wide & Accessibility & $\begin{array}{l}\text { ABA } \\
\text { compliance }\end{array}$ \\
\hline Green & $\begin{array}{l}\text { Ramps of moderate slope, not exceeding a rise of } \\
1: 12 \text { (one inch vertical per } 12 \text { inches horizontal }\end{array}$ & Accessibility & $\begin{array}{l}\text { ABA } \\
\text { compliance }\end{array}$ \\
\hline Green & Provides shortest accessible route to the facility & Accessibility & $\begin{array}{l}\text { ABA } \\
\text { compliance }\end{array}$ \\
\hline Amber & AccessibilityAG/UFAS accessible walkways & Accessibility & $\begin{array}{l}\text { ABA } \\
\text { compliance }\end{array}$ \\
\hline Amber & $\begin{array}{l}\text { Curb ramps are present where accessible routes } \\
\text { cross a curb }\end{array}$ & Accessibility & $\begin{array}{l}\text { ABA } \\
\text { compliance }\end{array}$ \\
\hline Amber & Ramps are minimum of 3 feet wide & Accessibility & $\begin{array}{l}\text { ABA } \\
\text { compliance }\end{array}$ \\
\hline Amber & $\begin{array}{l}\text { Ramps of moderate slope, not exceeding a rise of } \\
\text { 1:12 (one inch vertical per } 12 \text { inches horizontal }\end{array}$ & Accessibility & $\begin{array}{l}\text { ABA } \\
\text { compliance }\end{array}$ \\
\hline Red & $\begin{array}{l}\text { Does not meet AMBER column minimum } \\
\text { conditions }\end{array}$ & Accessibility & $\begin{array}{l}\text { ABA } \\
\text { compliance }\end{array}$ \\
\hline $\begin{array}{l}\text { ISR-I } \\
\text { Component }\end{array}$ & ISR-I Sub Component & ISR-I Priority & \\
\hline
\end{tabular}




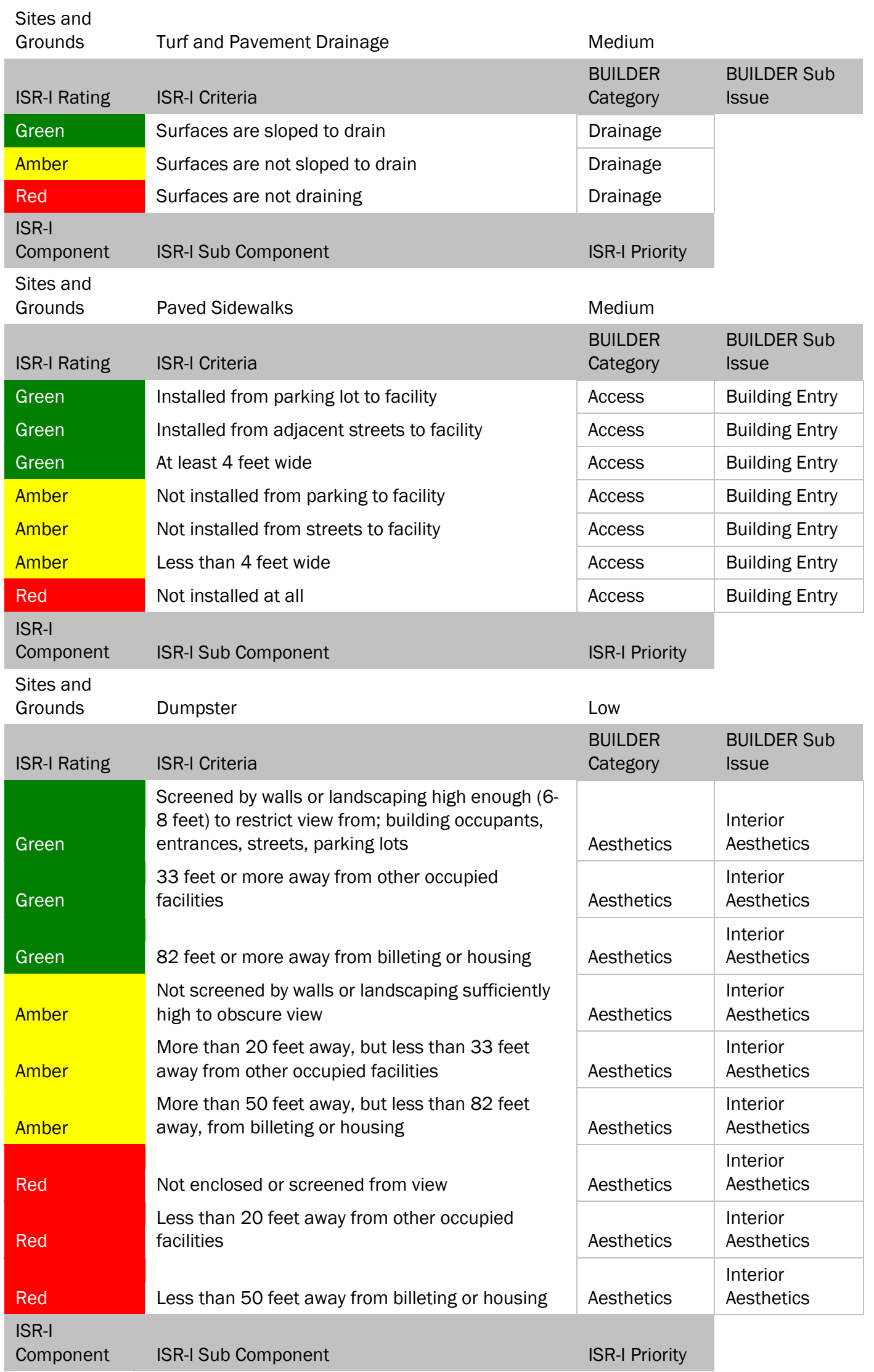




\begin{tabular}{|c|c|c|c|}
\hline $\begin{array}{l}\text { Sites and } \\
\text { Grounds }\end{array}$ & Utility Services & Low & \\
\hline ISR-I Rating & ISR-I Criteria & $\begin{array}{l}\text { BUILDER } \\
\text { Category }\end{array}$ & $\begin{array}{l}\text { BUILDER Sub } \\
\text { Issue }\end{array}$ \\
\hline Green & $\begin{array}{l}\text { Utility equipment is screened by landscaping or } \\
\text { fencing }\end{array}$ & Aesthetics & $\begin{array}{l}\text { Interior } \\
\text { Aesthetics }\end{array}$ \\
\hline Amber & $\begin{array}{l}\text { Utility equipment is screened by landscaping or } \\
\text { fencing }\end{array}$ & Aesthetics & $\begin{array}{l}\text { Interior } \\
\text { Aesthetics }\end{array}$ \\
\hline $\begin{array}{l}\text { ISR-I } \\
\text { Component }\end{array}$ & ISR-I Sub Component & ISR-I Priority & \\
\hline Parking & Disabled Parking & High & \\
\hline ISR-I Rating & ISR-I Criteria & $\begin{array}{l}\text { BUILDER } \\
\text { Category }\end{array}$ & $\begin{array}{l}\text { BUILDER Sub } \\
\text { Issue }\end{array}$ \\
\hline Green & 1-25 parking spaces - min req accessbile space 1 & Accessibility & $\begin{array}{l}\text { ABA } \\
\text { compliance }\end{array}$ \\
\hline Green & $\begin{array}{l}\text { 26-50 parking spaces - min req accessible } \\
\text { spaces } 2\end{array}$ & Accessibility & $\begin{array}{l}\text { ABA } \\
\text { compliance }\end{array}$ \\
\hline Green & $\begin{array}{l}\text { 51-75 parking spaces - min req accessible } \\
\text { spaces } 3\end{array}$ & Accessibility & $\begin{array}{l}\text { ABA } \\
\text { compliance }\end{array}$ \\
\hline Green & $\begin{array}{l}\text { 76-100 parking spaces - min req accessible } \\
\text { spaces } 4\end{array}$ & Accessibility & $\begin{array}{l}\text { ABA } \\
\text { compliance }\end{array}$ \\
\hline Green & $\begin{array}{l}\text { 101-150 parking spaces - min req accessible } \\
\text { spaces } 5\end{array}$ & Accessibility & $\begin{array}{l}\text { ABA } \\
\text { compliance }\end{array}$ \\
\hline Green & $\begin{array}{l}\text { 151-200 parking spaces - min req accessible } \\
\text { spaces } 6\end{array}$ & Accessibility & $\begin{array}{l}\text { ABA } \\
\text { compliance }\end{array}$ \\
\hline Green & $\begin{array}{l}\text { 201-300 parking spaces - min req accessible } \\
\text { spaces } 7\end{array}$ & Accessibility & $\begin{array}{l}\text { ABA } \\
\text { compliance }\end{array}$ \\
\hline Green & $\begin{array}{l}\text { 301-400 parking spaces - min req accessible } \\
\text { spaces } 8\end{array}$ & Accessibility & $\begin{array}{l}\text { ABA } \\
\text { compliance }\end{array}$ \\
\hline Green & $\begin{array}{l}401-500 \text { parking spaces - min req accessible } \\
\text { spaces } 9\end{array}$ & Accessibility & $\begin{array}{l}\text { ABA } \\
\text { compliance }\end{array}$ \\
\hline Green & $\begin{array}{l}501-1000 \text { parking spaces - min req accessible } \\
\text { spaces } 2 \% \text { of total }\end{array}$ & Accessibility & $\begin{array}{l}\text { ABA } \\
\text { compliance }\end{array}$ \\
\hline Green & $\begin{array}{l}1001 \text { and over parking spaces - } 20 \text { plus } 1 \text { for } \\
\text { each } 100\end{array}$ & Accessibility & $\begin{array}{l}\text { ABA } \\
\text { compliance }\end{array}$ \\
\hline Green & $\begin{array}{l}\text { For facilities mainly occupied by able-bodied } \\
\text { military personnel; The standard does not have to } \\
\text { be met, but spaces should be provided for } \\
\text { disabled personnel and visitors }\end{array}$ & Accessibility & $\begin{array}{l}\text { ABA } \\
\text { compliance }\end{array}$ \\
\hline Green & $\begin{array}{l}\text { Accessible parking spaces are at least } 8 \text { feet wide } \\
\text { and have } 5 \text { additional feet for exiting the car }\end{array}$ & Accessibility & $\begin{array}{l}\text { ABA } \\
\text { compliance }\end{array}$ \\
\hline Green & $\begin{array}{l}\text { Disabled parking is the shortest possible route to } \\
\text { an accessible entrance }\end{array}$ & Accessibility & $\begin{array}{l}\text { ABA } \\
\text { compliance }\end{array}$ \\
\hline Green & Accessible spaces are designated with signs & Accessibility & $\begin{array}{l}\text { ABA } \\
\text { compliance }\end{array}$ \\
\hline Green & $\begin{array}{l}\text { Curb ramps are available wherever an accessible } \\
\text { route crosses a curb at a rise or 1:12 or less }\end{array}$ & Accessibility & $\begin{array}{l}\text { ABA } \\
\text { compliance }\end{array}$ \\
\hline Green & $\begin{array}{l}\text { Ramps available from disabled parking, as } \\
\text { needed with maximum rise of } 1: 12\end{array}$ & Accessibility & $\begin{array}{l}\text { ABA } \\
\text { compliance }\end{array}$ \\
\hline
\end{tabular}




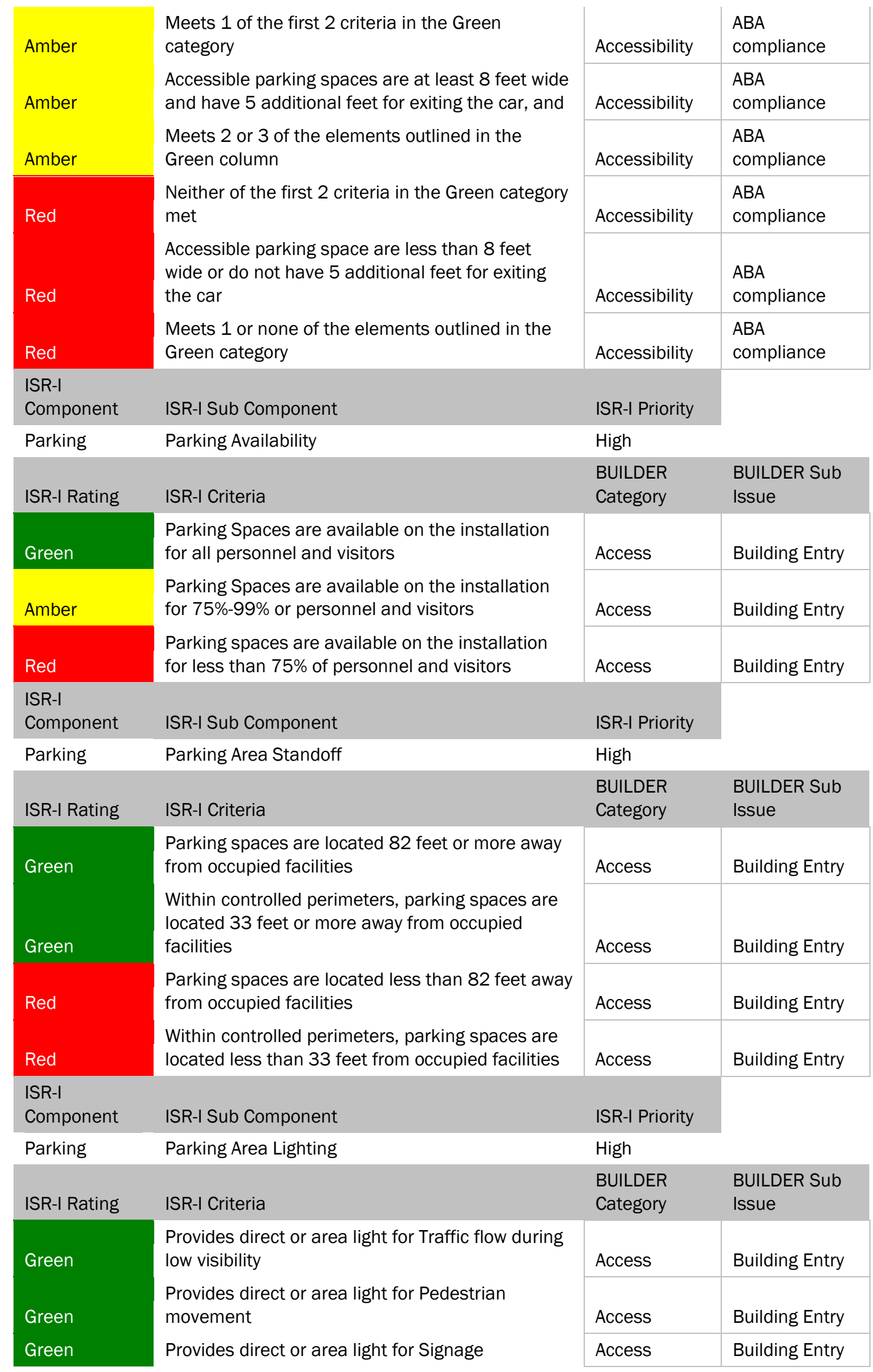




\begin{tabular}{|c|c|c|c|}
\hline Amber & $\begin{array}{l}\text { Not more than } 1 \text { of the } 3 \text { types of lighting in the } \\
\text { Green category is missing }\end{array}$ & Access & Building Entry \\
\hline Red & $\begin{array}{l}\text { More than } 1 \text { of the } 3 \text { types of lighting in the Green } \\
\text { category is missing }\end{array}$ & Access & Building Entry \\
\hline Red & Parking areas are not illuminated & Access & Building Entry \\
\hline $\begin{array}{l}\text { ISR-I } \\
\text { Component }\end{array}$ & ISR-I Sub Component & ISR-I Priority & \\
\hline Parking & Parking Pavement Drainage & High & \\
\hline ISR-I Rating & ISR-I Criteria & $\begin{array}{l}\text { BUILDER } \\
\text { Category }\end{array}$ & $\begin{array}{l}\text { BUILDER Sub } \\
\text { Issue }\end{array}$ \\
\hline Green & Sloped to drain & Drainage & \\
\hline Amber & Not well sloped to drain & Drainage & \\
\hline Red & Not draining & Drainage & \\
\hline $\begin{array}{l}\text { ISR-I } \\
\text { Component }\end{array}$ & ISR-I Sub Component & ISR-I Priority & \\
\hline Parking & Parking Spaces & Medium & \\
\hline ISR-I Rating & ISR-I Criteria & $\begin{array}{l}\text { BUILDER } \\
\text { Category }\end{array}$ & $\begin{array}{l}\text { BUILDER Sub } \\
\text { Issue }\end{array}$ \\
\hline Green & Sized $8.5 \mathrm{ft}$ wide by $16-18$ feet long & & \\
\hline Red & Less than 8.5 wide by $16-18$ feet long & & \\
\hline $\begin{array}{l}\text { ISR-I } \\
\text { Component }\end{array}$ & ISR-I Sub Component & ISR-I Priority & \\
\hline Parking & Parking Signage & Low & \\
\hline ISR-I Rating & ISR-I Criteria & $\begin{array}{l}\text { BUILDER } \\
\text { Category }\end{array}$ & $\begin{array}{l}\text { BUILDER Sub } \\
\text { Issue }\end{array}$ \\
\hline Green & $\begin{array}{l}\text { Signs provide directions from parking areas along } \\
\text { walkways to the facility }\end{array}$ & Access & $\begin{array}{l}\text { Directional Info } \\
\text { and Signage }\end{array}$ \\
\hline Amber & $\begin{array}{l}\text { Signs providing directions from parking areas } \\
\text { along walkways to the facility are not current or } \\
\text { are illegible }\end{array}$ & Access & $\begin{array}{l}\text { Directional Info } \\
\text { and Signage }\end{array}$ \\
\hline Red & No signs from parking to the facility & Access & $\begin{array}{l}\text { Directional Info } \\
\text { and Signage }\end{array}$ \\
\hline $\begin{array}{l}\text { ISR-I } \\
\text { Component }\end{array}$ & ISR-I Sub Component & ISR-I Priority & \\
\hline $\begin{array}{l}\text { Building } \\
\text { Exterior - } \\
\text { General }\end{array}$ & Outside Drainage & High & \\
\hline ISR-I Rating & ISR-I Criteria & $\begin{array}{l}\text { BUILDER } \\
\text { Category }\end{array}$ & $\begin{array}{l}\text { BUILDER Sub } \\
\text { Issue }\end{array}$ \\
\hline Green & Outflow drains away from the building & Drainage & \\
\hline Amber & $\begin{array}{l}\text { Outflow ponds at the building base around splash } \\
\text { blocks }\end{array}$ & Drainage & \\
\hline Red & Outflow ponds at building base; no splash blocks & Drainage & \\
\hline $\begin{array}{l}\text { ISR-I } \\
\text { Component }\end{array}$ & ISR-I Sub Component & ISR-I Priority & \\
\hline $\begin{array}{l}\text { Building } \\
\text { Exterior - } \\
\text { General }\end{array}$ & Exterior Lighting & High & \\
\hline
\end{tabular}




\begin{tabular}{|c|c|c|c|}
\hline ISR-I Rating & ISR-I Criteria & $\begin{array}{l}\text { BUILDER } \\
\text { Category }\end{array}$ & $\begin{array}{l}\text { BUILDER Sub } \\
\text { Issue }\end{array}$ \\
\hline Green & Provides direct or area lighting for: & Access & Building Entry \\
\hline Green & Security & Access & Building Entry \\
\hline Green & Pedestrian movement & Access & Building Entry \\
\hline Green & Safety and exit routes & Access & Building Entry \\
\hline Green & General exterior & Access & Building Entry \\
\hline Amber & $\begin{array}{l}\text { Not more than } 1 \text { of the } 4 \text { types of lighting in the } \\
\text { Green column is missing }\end{array}$ & Access & Building Entry \\
\hline $\begin{array}{l}\text { ISR-I } \\
\text { Component }\end{array}$ & ISR-I Sub Component & ISR-I Priority & \\
\hline
\end{tabular}

Building

Exterior -

General Disabled Access High

\begin{tabular}{|c|c|c|c|}
\hline ISR-I Rating & ISR-I Criteria & $\begin{array}{l}\text { BUILDER } \\
\text { Category }\end{array}$ & $\begin{array}{l}\text { BUILDER Sub } \\
\text { Issue }\end{array}$ \\
\hline Green & \multirow{2}{*}{$\begin{array}{l}\text { At least } 1 \text { main entry dorr allows diabled access to } \\
\text { each public or work space within the building } \\
\text { At entries with doors in series, clearances for the } \\
\text { disabled are } 48 \text { inches clear of any door swing }\end{array}$} & Accessibility & $\begin{array}{l}\text { ABA } \\
\text { compliance }\end{array}$ \\
\hline Green & & Accessibility & $\begin{array}{l}\text { ABA } \\
\text { compliance }\end{array}$ \\
\hline Green & \multirow{2}{*}{$\begin{array}{l}\text { Next to any revoloving door there is (at a } \\
\text { minimum) a single leaf door for the disabled } \\
\text { A service entry is not the sole disabled accessible } \\
\text { entry, unless it is the only entry }\end{array}$} & Accessibility & $\begin{array}{l}\text { ABA } \\
\text { compliance }\end{array}$ \\
\hline Green & & Accessibility & $\begin{array}{l}\text { ABA } \\
\text { compliance }\end{array}$ \\
\hline Green & \multirow{2}{*}{$\begin{array}{l}\text { Accessible exit door connects to bus stops, } \\
\text { disabled parking/loading zones, and public } \\
\text { streets by an accessible route } \\
3 \text { or more of the } 5 \text { conditions in the Green column } \\
\text { are met }\end{array}$} & Accessibility & $\begin{array}{l}\text { ABA } \\
\text { compliance }\end{array}$ \\
\hline Amber & & Accessibility & $\begin{array}{l}\text { ABA } \\
\text { compliance }\end{array}$ \\
\hline \multirow[t]{2}{*}{ Red } & \multirow[t]{2}{*}{$\begin{array}{l}\text { Less than } 3 \text { of the } 5 \text { conditions in the Green } \\
\text { column are met, or }\end{array}$} & Accessibility & $\begin{array}{l}\text { ABA } \\
\text { compliance }\end{array}$ \\
\hline & & Accessibility & $\begin{array}{l}\text { ABA } \\
\text { compliance }\end{array}$ \\
\hline $\begin{array}{l}\text { ISR-I } \\
\text { Component }\end{array}$ & ISR-I Sub Component & ISR-I Priority & \\
\hline
\end{tabular}

Building

Exterior -

General Building Exterior Signage Medium

\begin{tabular}{|c|c|c|c|}
\hline ISR-I Rating & ISR-I Criteria & $\begin{array}{l}\text { BUILDER } \\
\text { Category }\end{array}$ & $\begin{array}{l}\text { BUILDER Sub } \\
\text { Issue }\end{array}$ \\
\hline Green & ADAAG/UFAS compliant & Access & $\begin{array}{l}\text { Directional Info } \\
\text { and Signage }\end{array}$ \\
\hline Green & Coordinated, clearly visible, and readable & Access & $\begin{array}{l}\text { Directional Info } \\
\text { and Signage }\end{array}$ \\
\hline Green & $\begin{array}{l}\text { Includes directions to parking, entrances, and } \\
\text { facilities }\end{array}$ & Access & $\begin{array}{l}\text { Directional Info } \\
\text { and Signage }\end{array}$ \\
\hline Green & Information is current & Access & $\begin{array}{l}\text { Directional Info } \\
\text { and Signage }\end{array}$ \\
\hline
\end{tabular}




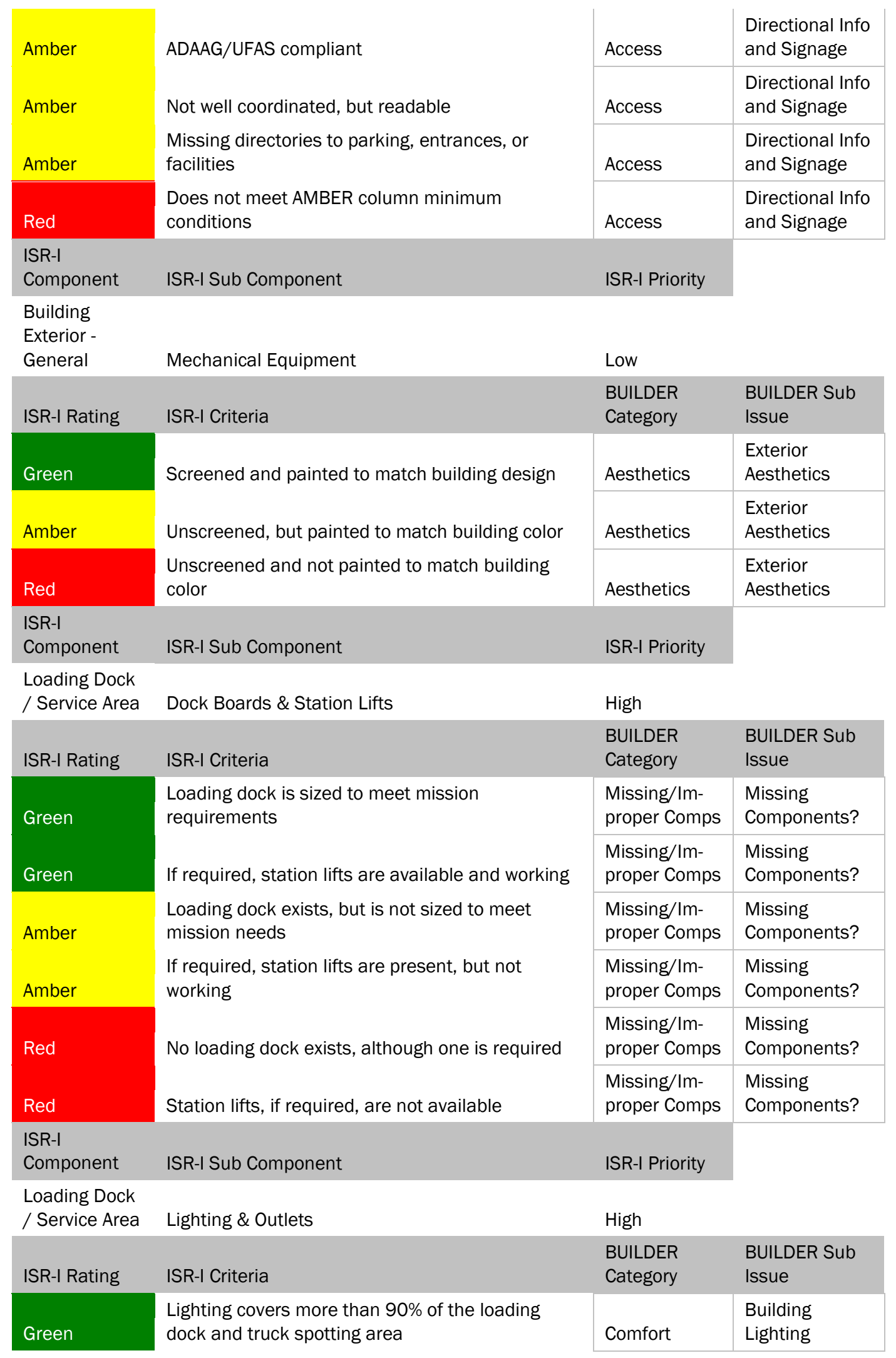




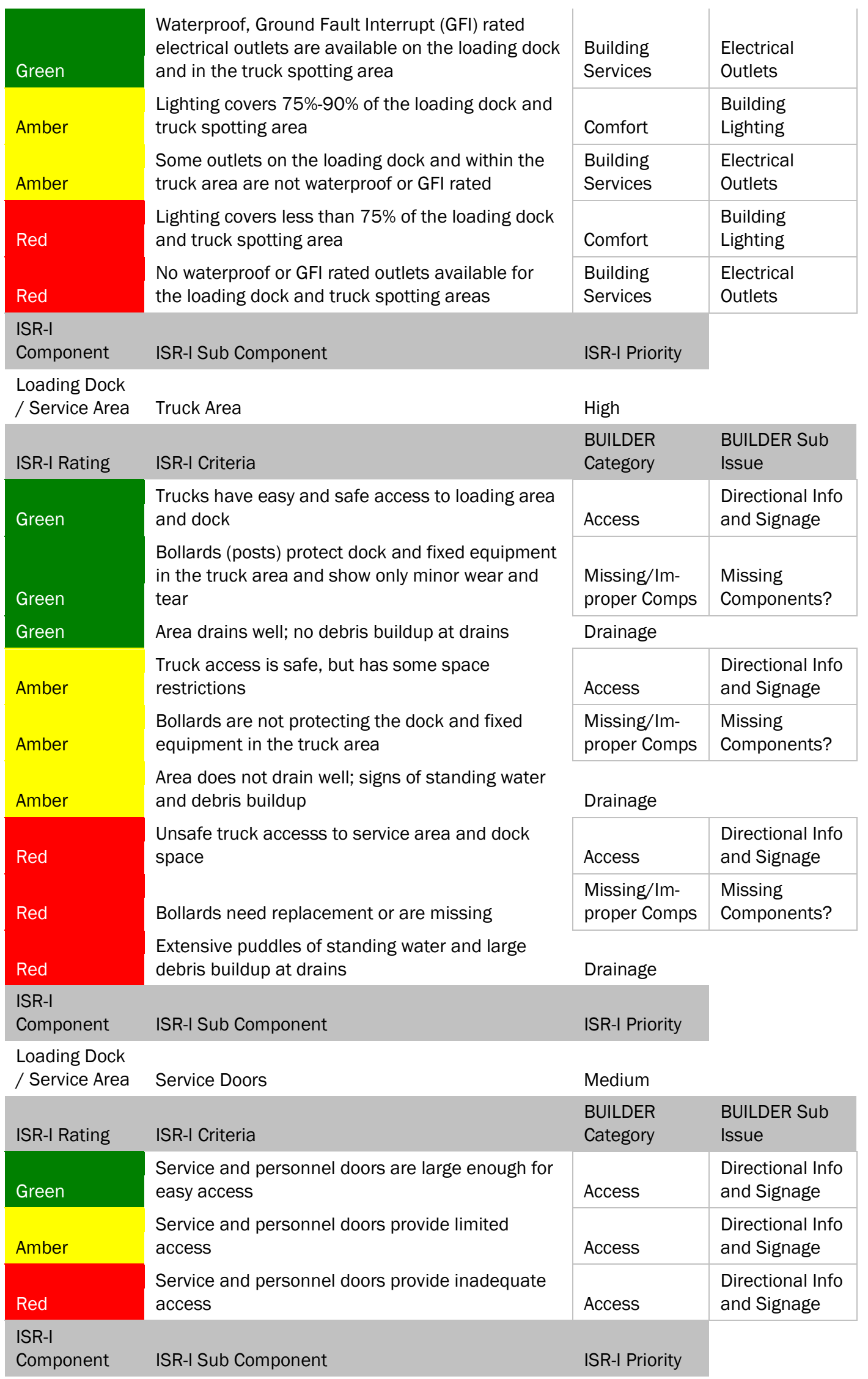




\begin{tabular}{|c|c|c|c|}
\hline $\begin{array}{l}\text { Loading Dock } \\
\text { / Service Area }\end{array}$ & Dock Walls & \multicolumn{2}{|l|}{ Low } \\
\hline ISR-I Rating & ISR-I Criteria & $\begin{array}{l}\text { BUILDER } \\
\text { Category }\end{array}$ & $\begin{array}{l}\text { BUILDER Sub } \\
\text { Issue }\end{array}$ \\
\hline Green & $\begin{array}{l}\text { Bollards (posts) protect dock walls, corners and } \\
\text { doorways from Material Handling Equipment } \\
\text { (MHE) }\end{array}$ & $\begin{array}{l}\text { Missing/Im- } \\
\text { proper Comps }\end{array}$ & $\begin{array}{l}\text { Missing } \\
\text { Components? }\end{array}$ \\
\hline Amber & $\begin{array}{l}\text { Bollards are in place, but do not protect dock } \\
\text { walls, corners, and/or doorways }\end{array}$ & $\begin{array}{l}\text { Missing/Im- } \\
\text { proper Comps }\end{array}$ & $\begin{array}{l}\text { Missing } \\
\text { Components? }\end{array}$ \\
\hline Red & Bollards need to be replaced or are missing & $\begin{array}{l}\text { Missing/Im- } \\
\text { proper Comps }\end{array}$ & $\begin{array}{l}\text { Missing } \\
\text { Components? }\end{array}$ \\
\hline $\begin{array}{l}\text { ISR-I } \\
\text { Component }\end{array}$ & ISR-I Sub Component & ISR-I Priority & \\
\hline Corridors & Corridor Transit Area & High & \\
\hline ISR-I Rating & ISR-I Criteria & $\begin{array}{l}\text { BUILDER } \\
\text { Category }\end{array}$ & $\begin{array}{l}\text { BUILDER Sub } \\
\text { Issue }\end{array}$ \\
\hline Green & Minimum of 4 feet wide & $\begin{array}{l}\text { Size/Configur } \\
\text { ation }\end{array}$ & $\begin{array}{l}\text { Building } \\
\text { Configuration }\end{array}$ \\
\hline Green & Fire extinguishers in secure boxes & $\begin{array}{l}\text { Size/Configur } \\
\text { ation }\end{array}$ & $\begin{array}{l}\text { Building } \\
\text { Configuration }\end{array}$ \\
\hline Amber & Corridors meet 2 of the 3 bulleted elements & $\begin{array}{l}\text { Size/Configur } \\
\text { ation }\end{array}$ & $\begin{array}{l}\text { Building } \\
\text { Configuration }\end{array}$ \\
\hline Red & $\begin{array}{l}\text { Less than } 2 \text { of the bulleted elements in the Green } \\
\text { column are met }\end{array}$ & $\begin{array}{l}\text { Size/Configur } \\
\text { ation }\end{array}$ & $\begin{array}{l}\text { Building } \\
\text { Configuration }\end{array}$ \\
\hline $\begin{array}{l}\text { ISR-I } \\
\text { Component }\end{array}$ & ISR-I Sub Component & ISR-I Priority & \\
\hline Corridors & Lighting \& Outlets & High & \\
\hline ISR-I Rating & ISR-I Criteria & $\begin{array}{l}\text { BUILDER } \\
\text { Category }\end{array}$ & $\begin{array}{l}\text { BUILDER Sub } \\
\text { Issue }\end{array}$ \\
\hline Green & $\begin{array}{l}\text { At least one electrical duplex (three prong } \\
\text { grounded) outlet on all wall surfaces }\end{array}$ & $\begin{array}{l}\text { Building } \\
\text { Services }\end{array}$ & $\begin{array}{l}\text { Electrical } \\
\text { Outlets }\end{array}$ \\
\hline Amber & One or more walls lack grounded duplex outlets & $\begin{array}{l}\text { Building } \\
\text { Services }\end{array}$ & $\begin{array}{l}\text { Electrical } \\
\text { Outlets }\end{array}$ \\
\hline Red & No grounded duplex outlets in Lobby, or & $\begin{array}{l}\text { Building } \\
\text { Services }\end{array}$ & $\begin{array}{l}\text { Electrical } \\
\text { Outlets }\end{array}$ \\
\hline $\begin{array}{l}\text { ISR-I } \\
\text { Component }\end{array}$ & ISR-I Sub Component & ISR-I Priority & \\
\hline Corridors & Corridor Doors & Medium & \\
\hline ISR-I Rating & ISR-I Criteria & $\begin{array}{l}\text { BUILDER } \\
\text { Category }\end{array}$ & $\begin{array}{l}\text { BUILDER Sub } \\
\text { Issue }\end{array}$ \\
\hline Green & $\begin{array}{l}\text { Allow access by the disabled to public or work } \\
\text { spaces in the facility }\end{array}$ & Accessibility & $\begin{array}{l}\text { ABA } \\
\text { compliance }\end{array}$ \\
\hline Green & $\begin{array}{l}\text { Interior doors that are also fire/exit doors, and } \\
\text { normally in an open position, are equipped with } \\
\text { automatic closure devices and panic hardware }\end{array}$ & $\begin{array}{l}\text { Missing/Im- } \\
\text { proper Comps }\end{array}$ & $\begin{array}{l}\text { Missing } \\
\text { Components? }\end{array}$ \\
\hline Green & $\begin{array}{l}\text { Interior doors that exit to the exterior are metal or } \\
\text { solid core wood and open easily from the inside }\end{array}$ & Access & Building Egress \\
\hline Green & $\begin{array}{l}\text { Panic hardware does not require a key or special } \\
\text { tools to open from inside. }\end{array}$ & $\begin{array}{l}\text { Missing/Im- } \\
\text { proper Comps }\end{array}$ & $\begin{array}{l}\text { Missing } \\
\text { Components? }\end{array}$ \\
\hline
\end{tabular}




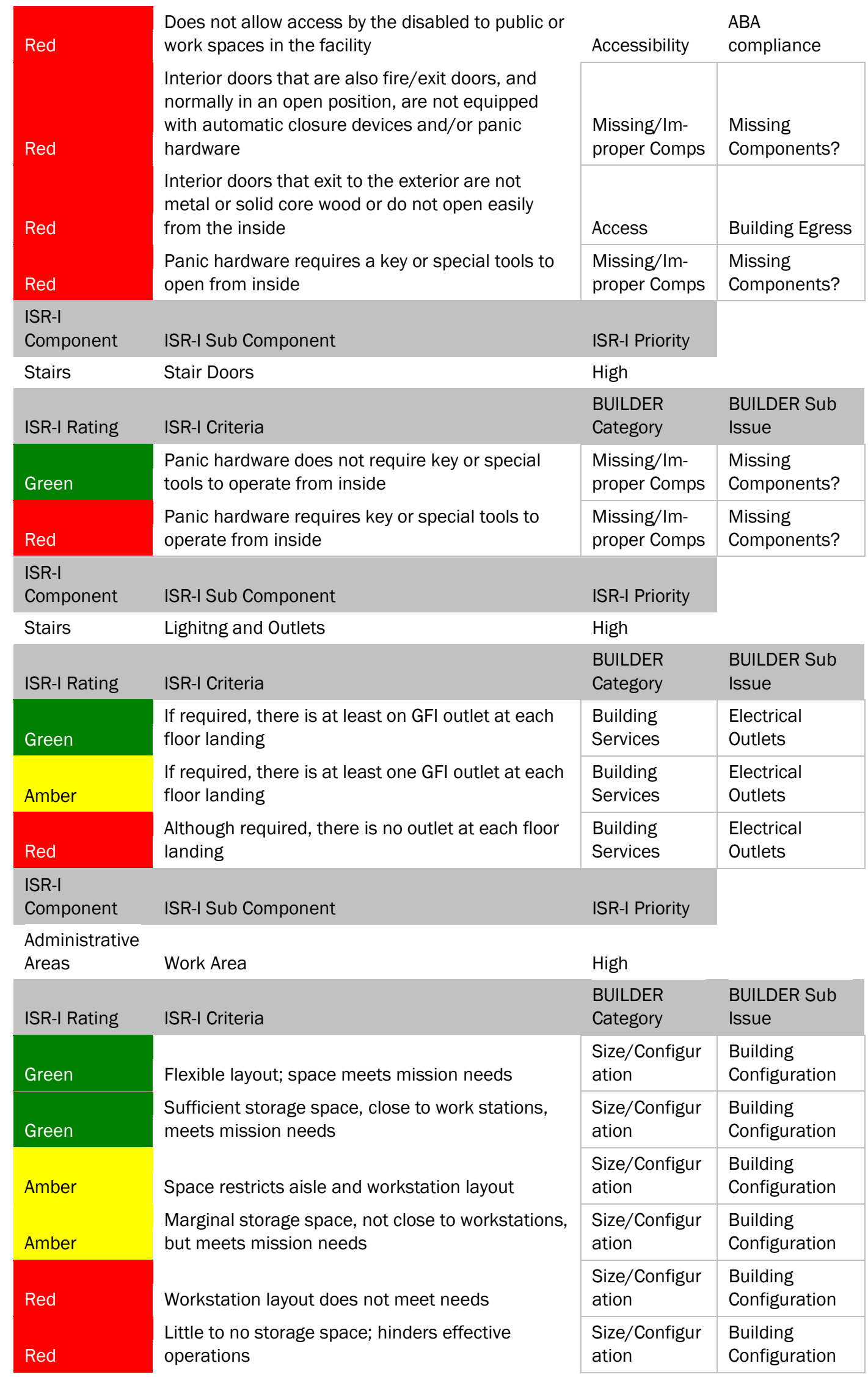




\begin{tabular}{|c|c|c|c|}
\hline $\begin{array}{l}\text { ISR-I } \\
\text { Component }\end{array}$ & ISR-I Sub Component & ISR-I Priority & \\
\hline $\begin{array}{l}\text { Administrative } \\
\text { Areas }\end{array}$ & Lighting and Outlets & High & \\
\hline ISR-I Rating & ISR-I Criteria & $\begin{array}{l}\text { BUILDER } \\
\text { Category }\end{array}$ & $\begin{array}{l}\text { BUILDER Sub } \\
\text { Issue }\end{array}$ \\
\hline Green & $\begin{array}{l}\text { At least one electrical duplex (three prong } \\
\text { grounded) outlet at all workstations }\end{array}$ & $\begin{array}{l}\text { Building } \\
\text { Services }\end{array}$ & $\begin{array}{l}\text { Electrical } \\
\text { Outlets }\end{array}$ \\
\hline Green & $\begin{array}{l}\text { Besides workstations, there is at least one } \\
\text { electrical duplex outlet on all interior walls of the } \\
\text { area }\end{array}$ & $\begin{array}{l}\text { Building } \\
\text { Services }\end{array}$ & $\begin{array}{l}\text { Electrical } \\
\text { Outlets }\end{array}$ \\
\hline Amber & One or more walls lack grounded duplex outlets & $\begin{array}{l}\text { Building } \\
\text { Services }\end{array}$ & $\begin{array}{l}\text { Electrical } \\
\text { Outlets }\end{array}$ \\
\hline Amber & $\begin{array}{l}\text { Besides workstations, there is at least one } \\
\text { electrical duplex outlet on } 1 \text { wall of the area }\end{array}$ & $\begin{array}{l}\text { Building } \\
\text { Services }\end{array}$ & $\begin{array}{l}\text { Electrical } \\
\text { Outlets }\end{array}$ \\
\hline Red & No grounded duplex outlets at workstations & $\begin{array}{l}\text { Building } \\
\text { Services }\end{array}$ & $\begin{array}{l}\text { Electrical } \\
\text { Outlets }\end{array}$ \\
\hline Red & $\begin{array}{l}\text { No additional electrical outlets other than those at } \\
\text { workstations }\end{array}$ & $\begin{array}{l}\text { Building } \\
\text { Services }\end{array}$ & $\begin{array}{l}\text { Electrical } \\
\text { Outlets }\end{array}$ \\
\hline $\begin{array}{l}\text { ISR-I } \\
\text { Component }\end{array}$ & ISR-I Sub Component & ISR-I Priority & \\
\hline $\begin{array}{l}\text { Administrative } \\
\text { Areas }\end{array}$ & Interior Doors & Medium & \\
\hline ISR-I Rating & ISR-I Criteria & $\begin{array}{l}\text { BUILDER } \\
\text { Category }\end{array}$ & $\begin{array}{l}\text { BUILDER Sub } \\
\text { Issue }\end{array}$ \\
\hline Red & $\begin{array}{l}\text { Do not allow access by the disabled to public or } \\
\text { work spaces in the facility }\end{array}$ & Accessibility & $\begin{array}{l}\text { ABA } \\
\text { compliance }\end{array}$ \\
\hline Red & $\begin{array}{l}\text { Doors that exit to the exterior are not equipped } \\
\text { with fire/exit signs and panic hardware }\end{array}$ & $\begin{array}{l}\text { Missing/Im- } \\
\text { proper Comps }\end{array}$ & $\begin{array}{l}\text { Missing } \\
\text { Components? }\end{array}$ \\
\hline $\begin{array}{l}\text { ISR-I } \\
\text { Component }\end{array}$ & ISR-I Sub Component & ISR-I Priority & \\
\hline $\begin{array}{l}\text { Administrative } \\
\text { Areas }\end{array}$ & Computer/LAN system & Medium & \\
\hline ISR-I Rating & ISR-I Criteria & $\begin{array}{l}\text { BUILDER } \\
\text { Category }\end{array}$ & $\begin{array}{l}\text { BUILDER Sub } \\
\text { Issue }\end{array}$ \\
\hline Green & $\begin{array}{l}\text { Enough LAN outlets are available to support } \\
\text { current mission requirements }\end{array}$ & $\begin{array}{l}\text { Building } \\
\text { Services }\end{array}$ & $\begin{array}{l}\text { Building IT } \\
\text { System }\end{array}$ \\
\hline Amber & Not enough LAN outlets are available & $\begin{array}{l}\text { Building } \\
\text { Services }\end{array}$ & $\begin{array}{l}\text { Building IT } \\
\text { System }\end{array}$ \\
\hline Red & If required, LAN outlets are not available & $\begin{array}{l}\text { Building } \\
\text { Services }\end{array}$ & $\begin{array}{l}\text { Building IT } \\
\text { System }\end{array}$ \\
\hline $\begin{array}{l}\text { ISR-I } \\
\text { Component }\end{array}$ & ISR-I Sub Component & ISR-I Priority & \\
\hline $\begin{array}{l}\text { Administrative } \\
\text { Areas }\end{array}$ & Telephone System & Medium & \\
\hline ISR-I Rating & ISR-I Criteria & $\begin{array}{l}\text { BUILDER } \\
\text { Category }\end{array}$ & $\begin{array}{l}\text { BUILDER Sub } \\
\text { Issue }\end{array}$ \\
\hline Green & $\begin{array}{l}\text { Enough telephone jacks are available to support } \\
\text { current mission requirements }\end{array}$ & $\begin{array}{l}\text { Building } \\
\text { Services }\end{array}$ & $\begin{array}{l}\text { Telephone } \\
\text { System }\end{array}$ \\
\hline
\end{tabular}




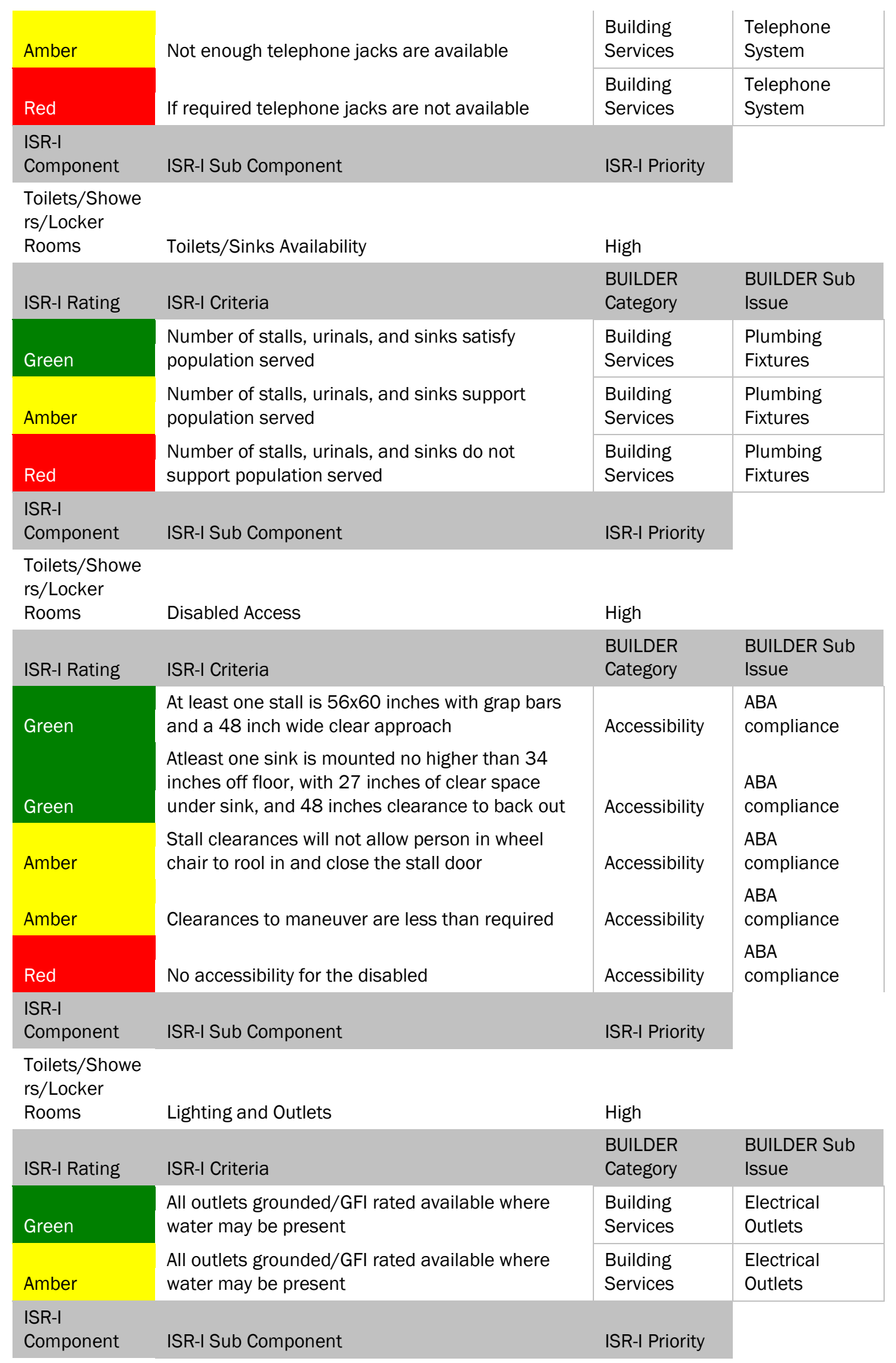




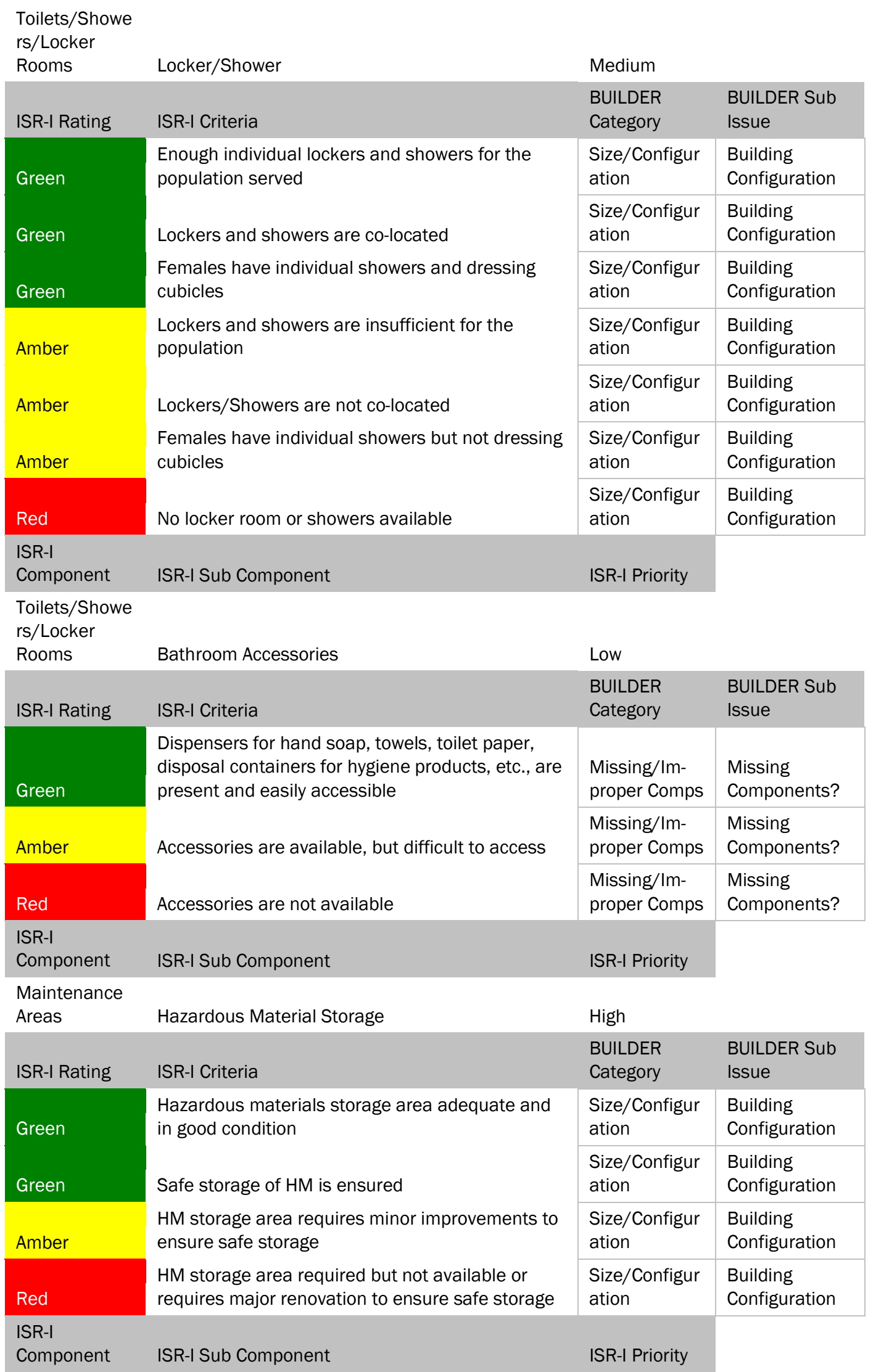




\begin{tabular}{|c|c|c|c|}
\hline $\begin{array}{l}\text { Maintenance } \\
\text { Areas }\end{array}$ & Hazardous Waste Storage Holding & High & \\
\hline ISR-I Rating & ISR-I Criteria & $\begin{array}{l}\text { BUILDER } \\
\text { Category }\end{array}$ & $\begin{array}{l}\text { BUILDER Sub } \\
\text { Issue }\end{array}$ \\
\hline Green & $\begin{array}{l}\text { Hazardous wastes holding facility adequate and in } \\
\text { good condition }\end{array}$ & $\begin{array}{l}\text { Size/Configur } \\
\text { ation }\end{array}$ & $\begin{array}{l}\text { Building } \\
\text { Configuration }\end{array}$ \\
\hline Green & Safe storage of Hazardous Waste ensuRed & $\begin{array}{l}\text { Size/Configur } \\
\text { ation }\end{array}$ & $\begin{array}{l}\text { Building } \\
\text { Configuration }\end{array}$ \\
\hline Amber & $\begin{array}{l}\text { Hazardous Waste holding facility requires minor } \\
\text { improvements to ensure safe storage }\end{array}$ & $\begin{array}{l}\text { Size/Configur } \\
\text { ation }\end{array}$ & $\begin{array}{l}\text { Building } \\
\text { Configuration }\end{array}$ \\
\hline Red & $\begin{array}{l}\text { Hazardous Waste holding facility required but not } \\
\text { available or requires major renovation to ensure } \\
\text { safe storage }\end{array}$ & $\begin{array}{l}\text { Size/Configur } \\
\text { ation }\end{array}$ & $\begin{array}{l}\text { Building } \\
\text { Configuration }\end{array}$ \\
\hline $\begin{array}{l}\text { ISR-I } \\
\text { Component }\end{array}$ & ISR-I Sub Component & ISR-I Priority & \\
\hline $\begin{array}{l}\text { Maintenance } \\
\text { Areas }\end{array}$ & Lightning Rods & High & \\
\hline ISR-I Rating & ISR-I Criteria & $\begin{array}{l}\text { BUILDER } \\
\text { Category }\end{array}$ & $\begin{array}{l}\text { BUILDER Sub } \\
\text { Issue }\end{array}$ \\
\hline Green & $\begin{array}{l}\text { Building lightning rods and grouding cables good } \\
\text { condition and properly anchored to building and } \\
\text { ground }\end{array}$ & $\begin{array}{l}\text { Environment/ } \\
\text { Life Safety }\end{array}$ & $\begin{array}{l}\text { Lightning } \\
\text { Protection }\end{array}$ \\
\hline Amber & $\begin{array}{l}\text { Building lightning rods and/or grounding cables } \\
\text { require repair or upgrading }\end{array}$ & $\begin{array}{l}\text { Environment/ } \\
\text { Life Safety }\end{array}$ & $\begin{array}{l}\text { Lightning } \\
\text { Protection }\end{array}$ \\
\hline Red & $\begin{array}{l}\text { Building lightning rods and/or grounding cables } \\
\text { required but not installed or not functional }\end{array}$ & $\begin{array}{l}\text { Environment/ } \\
\text { Life Safety }\end{array}$ & $\begin{array}{l}\text { Lightning } \\
\text { Protection }\end{array}$ \\
\hline $\begin{array}{l}\text { ISR-I } \\
\text { Component }\end{array}$ & ISR-I Sub Component & ISR-I Priority & \\
\hline $\begin{array}{l}\text { Maintenance } \\
\text { Areas }\end{array}$ & Lighting and Outlets & High & \\
\hline ISR-I Rating & ISR-I Criteria & $\begin{array}{l}\text { BUILDER } \\
\text { Category }\end{array}$ & $\begin{array}{l}\text { BUILDER Sub } \\
\text { Issue }\end{array}$ \\
\hline Green & $\begin{array}{l}\text { All outlets grounded/GFI rated available where } \\
\text { water may be present }\end{array}$ & $\begin{array}{l}\text { Building } \\
\text { Services }\end{array}$ & $\begin{array}{l}\text { Electrical } \\
\text { Outlets }\end{array}$ \\
\hline Amber & $\begin{array}{l}\text { All outlets grounded/GFI rated available where } \\
\text { water may be present }\end{array}$ & $\begin{array}{l}\text { Building } \\
\text { Services }\end{array}$ & $\begin{array}{l}\text { Electrical } \\
\text { Outlets }\end{array}$ \\
\hline Red & $\begin{array}{l}\text { Ungrounded outlets or outlets where water may } \\
\text { be present are not GFI rated }\end{array}$ & $\begin{array}{l}\text { Building } \\
\text { Services }\end{array}$ & $\begin{array}{l}\text { Electrical } \\
\text { Outlets }\end{array}$ \\
\hline $\begin{array}{l}\text { ISR-I } \\
\text { Component }\end{array}$ & ISR-I Sub Component & ISR-I Priority & \\
\hline $\begin{array}{l}\text { Maintenance } \\
\text { Areas }\end{array}$ & Vehicle Entrance & High & \\
\hline ISR-I Rating & ISR-I Criteria & $\begin{array}{l}\text { BUILDER } \\
\text { Category }\end{array}$ & $\begin{array}{l}\text { BUILDER Sub } \\
\text { Issue }\end{array}$ \\
\hline Green & $\begin{array}{l}\text { Approaches to building's vehicle entrances } \\
\text { provide sufficient maneuvering surface for } \\
\text { authorized vehicles requiring entrance } \\
\text { Maneuvering surface is paved and in good } \\
\text { condition }\end{array}$ & $\begin{array}{l}\text { Access } \\
\text { Access }\end{array}$ & $\begin{array}{l}\text { Building Entry } \\
\text { Building Entry }\end{array}$ \\
\hline
\end{tabular}




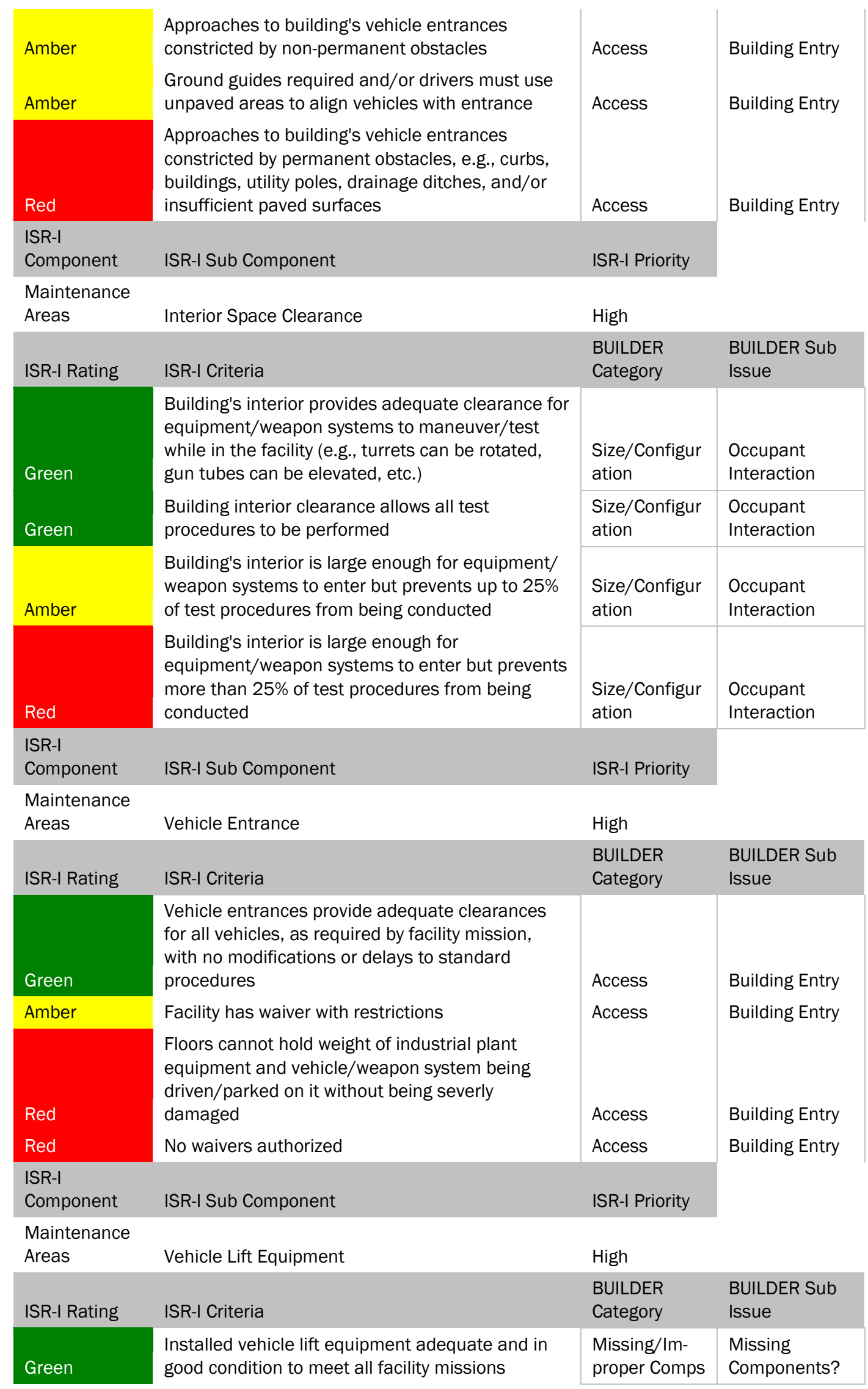




\begin{tabular}{|c|c|c|c|}
\hline Amber & $\begin{array}{l}\text { Lift equipment adequate to meet } 75 \% \text { of facility } \\
\text { missions }\end{array}$ & $\begin{array}{l}\text { Missing/Im- } \\
\text { proper Comps }\end{array}$ & $\begin{array}{l}\text { Missing } \\
\text { Components? }\end{array}$ \\
\hline Red & $\begin{array}{l}\text { Lift equipment not adequate to meet at least } 75 \% \\
\text { of facility missions }\end{array}$ & $\begin{array}{l}\text { Missing/Im- } \\
\text { proper Comps }\end{array}$ & $\begin{array}{l}\text { Missing } \\
\text { Components? }\end{array}$ \\
\hline $\begin{array}{l}\text { ISR-I } \\
\text { Component }\end{array}$ & ISR-I Sub Component & ISR-I Priority & \\
\hline $\begin{array}{l}\text { Maintenance } \\
\text { Areas }\end{array}$ & Crane & High & \\
\hline ISR-I Rating & ISR-I Criteria & $\begin{array}{l}\text { BUILDER } \\
\text { Category }\end{array}$ & $\begin{array}{l}\text { BUILDER Sub } \\
\text { Issue }\end{array}$ \\
\hline Green & $\begin{array}{l}\text { Cranes/hoists adequate and in good condition to } \\
\text { meet all facility missions }\end{array}$ & $\begin{array}{l}\text { Missing/Im- } \\
\text { proper Comps }\end{array}$ & $\begin{array}{l}\text { Missing } \\
\text { Components? }\end{array}$ \\
\hline Amber & $\begin{array}{l}\text { Cranes/hoists can lift } 75 \% \text { of loads required for } \\
\text { facility missions }\end{array}$ & $\begin{array}{l}\text { Missing/Im- } \\
\text { proper Comps }\end{array}$ & $\begin{array}{l}\text { Missing } \\
\text { Components? }\end{array}$ \\
\hline Red & Crane rails cannot support required loads & $\begin{array}{l}\text { Missing/Im- } \\
\text { proper Comps }\end{array}$ & $\begin{array}{l}\text { Missing } \\
\text { Components? }\end{array}$ \\
\hline $\begin{array}{l}\text { ISR-I } \\
\text { Component }\end{array}$ & ISR-I Sub Component & ISR-I Priority & \\
\hline $\begin{array}{l}\text { Maintenance } \\
\text { Areas }\end{array}$ & Bay Pits & High & \\
\hline ISR-I Rating & ISR-I Criteria & $\begin{array}{l}\text { BUILDER } \\
\text { Category }\end{array}$ & $\begin{array}{l}\text { BUILDER Sub } \\
\text { Issue }\end{array}$ \\
\hline Green & Bay Pits meet all needs for facility missions & $\begin{array}{l}\text { Missing/Im- } \\
\text { proper Comps }\end{array}$ & $\begin{array}{l}\text { Missing } \\
\text { Components? }\end{array}$ \\
\hline Amber & Bay Pits meet most needs for facility missions & $\begin{array}{l}\text { Missing/Im- } \\
\text { proper Comps }\end{array}$ & $\begin{array}{l}\text { Missing } \\
\text { Components? }\end{array}$ \\
\hline Red & $\begin{array}{l}\text { Bay pits do not meet the needs for facility } \\
\text { missions }\end{array}$ & $\begin{array}{l}\text { Missing/Im- } \\
\text { proper Comps }\end{array}$ & $\begin{array}{l}\text { Missing } \\
\text { Components? }\end{array}$ \\
\hline $\begin{array}{l}\text { ISR-I } \\
\text { Component }\end{array}$ & ISR-I Sub Component & ISR-I Priority & \\
\hline $\begin{array}{l}\text { Maintenance } \\
\text { Areas }\end{array}$ & Secure Area Availability & High & \\
\hline ISR-I Rating & ISR-I Criteria & $\begin{array}{l}\text { BUILDER } \\
\text { Category }\end{array}$ & $\begin{array}{l}\text { BUILDER Sub } \\
\text { Issue }\end{array}$ \\
\hline Green & $\begin{array}{l}\text { Secure area available for performing } \\
\text { communication security (COMSEC), intelligence } \\
\text { and electronic warfare (IEW) }\end{array}$ & $\begin{array}{l}\text { Building } \\
\text { Services }\end{array}$ & $\begin{array}{l}\text { Security } \\
\text { System }\end{array}$ \\
\hline Amber & Secure area security features require upgrading & $\begin{array}{l}\text { Building } \\
\text { Services }\end{array}$ & $\begin{array}{l}\text { Security } \\
\text { System }\end{array}$ \\
\hline Red & $\begin{array}{l}\text { Secure area not available for performing } \\
\text { communication security (COMSEC), intelligence } \\
\text { and electronic warfare (IEW), signals intelligence } \\
\text { (SIGINT), and/or small arms maintenance }\end{array}$ & $\begin{array}{l}\text { Building } \\
\text { Services }\end{array}$ & $\begin{array}{l}\text { Security } \\
\text { System }\end{array}$ \\
\hline $\begin{array}{l}\text { ISR-I } \\
\text { Component }\end{array}$ & ISR-I Sub Component & ISR-I Priority & \\
\hline $\begin{array}{l}\text { Maintenance } \\
\text { Areas }\end{array}$ & Computer/LAN System & High & \\
\hline ISR-I Rating & ISR-I Criteria & $\begin{array}{l}\text { BUILDER } \\
\text { Category }\end{array}$ & $\begin{array}{l}\text { BUILDER Sub } \\
\text { Issue }\end{array}$ \\
\hline
\end{tabular}




\begin{tabular}{|c|c|c|c|}
\hline Green & $\begin{array}{l}\text { Enough LAN outlets are available to support } \\
\text { current mission requirements }\end{array}$ & $\begin{array}{l}\text { Building } \\
\text { Services }\end{array}$ & $\begin{array}{l}\text { Building IT } \\
\text { System }\end{array}$ \\
\hline \multirow[t]{2}{*}{ Amber } & \multirow{2}{*}{$\begin{array}{l}\text { Not enough LAN outlets are available } \\
\text { If required, LAN outlets are not available }\end{array}$} & $\begin{array}{l}\text { Building } \\
\text { Services }\end{array}$ & $\begin{array}{l}\text { Building IT } \\
\text { System }\end{array}$ \\
\hline & & $\begin{array}{l}\text { Building } \\
\text { Services }\end{array}$ & $\begin{array}{l}\text { Building IT } \\
\text { System }\end{array}$ \\
\hline $\begin{array}{l}\text { ISR-I } \\
\text { Component }\end{array}$ & ISR-I Sub Component & \multirow{2}{*}{\multicolumn{2}{|c|}{ ISR-I Priority }} \\
\hline $\begin{array}{l}\text { Maintenance } \\
\text { Areas }\end{array}$ & Telephone System & & \\
\hline ISR-I Rating & ISR-I Criteria & $\begin{array}{l}\text { BUILDER } \\
\text { Category }\end{array}$ & $\begin{array}{l}\text { BUILDER Sub } \\
\text { Issue }\end{array}$ \\
\hline Green & \multirow[t]{3}{*}{$\begin{array}{l}\text { Enough telephone jacks are available to support } \\
\text { current mission requirements }\end{array}$} & $\begin{array}{l}\text { Building } \\
\text { Services }\end{array}$ & $\begin{array}{l}\text { Telephone } \\
\text { System }\end{array}$ \\
\hline Amber & & $\begin{array}{l}\text { Building } \\
\text { Services }\end{array}$ & $\begin{array}{l}\text { Telephone } \\
\text { System }\end{array}$ \\
\hline Red & & $\begin{array}{l}\text { Building } \\
\text { Services }\end{array}$ & $\begin{array}{l}\text { Telephone } \\
\text { System }\end{array}$ \\
\hline \multicolumn{4}{|c|}{ ISR-I Sub Component } \\
\hline \multicolumn{4}{|l|}{$\begin{array}{l}\text { Maintenance } \\
\text { Areas }\end{array}$} \\
\hline ISR-I Rating & ISR-I Criteria & $\begin{array}{l}\text { BUILDER } \\
\text { Category }\end{array}$ & $\begin{array}{l}\text { BUILDER Sub } \\
\text { Issue }\end{array}$ \\
\hline Green & \multirow{3}{*}{$\begin{array}{l}\text { Battery shop complies with OSHA, Federal and } \\
\text { State standards } \\
\text { Shop has automatic neutralization capability and } \\
\text { built-in power distribution panels } \\
\text { Floor is acid resistant; drain connected to } \\
\text { collection tank }\end{array}$} & $\begin{array}{l}\text { Size/Configur } \\
\text { ation }\end{array}$ & $\begin{array}{l}\text { Building } \\
\text { Configuration }\end{array}$ \\
\hline Green & & $\begin{array}{l}\text { Size/Configur } \\
\text { ation }\end{array}$ & $\begin{array}{l}\text { Building } \\
\text { Configuration }\end{array}$ \\
\hline Green & & $\begin{array}{l}\text { Size/Configur } \\
\text { ation }\end{array}$ & $\begin{array}{l}\text { Building } \\
\text { Configuration }\end{array}$ \\
\hline Amber & \multirow{2}{*}{$\begin{array}{l}\text { Facility has waiver with restrictions } \\
\text { Battery shop approved but requires manual acid } \\
\text { neutralization }\end{array}$} & $\begin{array}{l}\text { Size/Configur } \\
\text { ation }\end{array}$ & $\begin{array}{l}\text { Building } \\
\text { Configuration }\end{array}$ \\
\hline Amber & & $\begin{array}{l}\text { Size/Configur } \\
\text { ation }\end{array}$ & $\begin{array}{l}\text { Building } \\
\text { Configuration }\end{array}$ \\
\hline Amber & \multirow[t]{3}{*}{ Lacks floor drainage, and/or power distribution } & $\begin{array}{l}\text { Size/Configur } \\
\text { ation }\end{array}$ & $\begin{array}{l}\text { Building } \\
\text { Configuration }\end{array}$ \\
\hline \multirow[t]{2}{*}{ Red } & & $\begin{array}{l}\text { Size/Configur } \\
\text { ation }\end{array}$ & $\begin{array}{l}\text { Building } \\
\text { Configuration }\end{array}$ \\
\hline & & $\begin{array}{l}\text { Size/Configur } \\
\text { ation }\end{array}$ & $\begin{array}{l}\text { Building } \\
\text { Configuration }\end{array}$ \\
\hline $\begin{array}{l}\text { ISR-I } \\
\text { Component }\end{array}$ & ISR-I Sub Component & ISR-I Priority & \\
\hline \multicolumn{3}{|l|}{ Maintenance } & \\
\hline ISR-I Rating & ISR-I Criteria & $\begin{array}{l}\text { BUILDER } \\
\text { Category }\end{array}$ & $\begin{array}{l}\text { BUILDER Sub } \\
\text { Issue }\end{array}$ \\
\hline Green & Floor slopes towards drains & Drainage & \\
\hline Amber & $\begin{array}{l}\text { Drain pipes not large enough, resulting in slow } \\
\text { drainage }\end{array}$ & Drainage & \\
\hline
\end{tabular}




\begin{tabular}{|c|c|c|c|}
\hline Red & $\begin{array}{l}\text { Drains not connected to wast water collection or } \\
\text { treatment system }\end{array}$ & Drainage & \\
\hline $\begin{array}{l}\text { ISR-I } \\
\text { Component }\end{array}$ & ISR-I Sub Component & ISR-I Priority & \\
\hline $\begin{array}{l}\text { Maintenance } \\
\text { Areas }\end{array}$ & Water Availability & Medium & \\
\hline ISR-I Rating & ISR-I Criteria & $\begin{array}{l}\text { BUILDER } \\
\text { Category }\end{array}$ & $\begin{array}{l}\text { BUILDER Sub } \\
\text { Issue }\end{array}$ \\
\hline Green & Water lines available in required locations & $\begin{array}{l}\text { Building } \\
\text { Services }\end{array}$ & Water Supply \\
\hline Amber & Water lines available $75 \%$ of required locations & $\begin{array}{l}\text { Building } \\
\text { Services }\end{array}$ & Water Supply \\
\hline Red & Water lines not available at required locations & $\begin{array}{l}\text { Building } \\
\text { Services }\end{array}$ & Water Supply \\
\hline $\begin{array}{l}\text { ISR-I } \\
\text { Component }\end{array}$ & ISR-I Sub Component & ISR-I Priority & \\
\hline $\begin{array}{l}\text { Centralized } \\
\text { Vehicle Wash } \\
\text { Facility }\end{array}$ & Pits/Lifts & High & \\
\hline ISR-I Rating & ISR-I Criteria & $\begin{array}{l}\text { BUILDER } \\
\text { Category }\end{array}$ & $\begin{array}{l}\text { BUILDER Sub } \\
\text { Issue }\end{array}$ \\
\hline Green & Pits and lifts meet all needs for facility missions & $\begin{array}{l}\text { Missing/Im- } \\
\text { proper Comps }\end{array}$ & $\begin{array}{l}\text { Missing } \\
\text { Components? }\end{array}$ \\
\hline Amber & Pits and lifts meet most needs for facility missions & $\begin{array}{l}\text { Missing/Im- } \\
\text { proper Comps }\end{array}$ & $\begin{array}{l}\text { Missing } \\
\text { Components? }\end{array}$ \\
\hline Red & $\begin{array}{l}\text { Pits and lifts do not meet the needs for facility } \\
\text { missions }\end{array}$ & $\begin{array}{l}\text { Missing/Im- } \\
\text { proper Comps }\end{array}$ & $\begin{array}{l}\text { Missing } \\
\text { Components? }\end{array}$ \\
\hline $\begin{array}{l}\text { ISR-I } \\
\text { Component }\end{array}$ & ISR-I Sub Component & ISR-I Priority & \\
\hline $\begin{array}{l}\text { Centralized } \\
\text { Vehicle Wash } \\
\text { Facility }\end{array}$ & Drainage/Containment & High & \\
\hline ISR-I Rating & ISR-I Criteria & $\begin{array}{l}\text { BUILDER } \\
\text { Category }\end{array}$ & $\begin{array}{l}\text { BUILDER Sub } \\
\text { Issue }\end{array}$ \\
\hline Green & $\begin{array}{l}\text { Dike sufficient to contain and prevent runoff from } \\
\text { leaking into surrounding areas }\end{array}$ & Drainage & \\
\hline Amber & $\begin{array}{l}\text { Dikes insufficient to contain and prevent runoff } \\
\text { from leaking into surrounding areas }\end{array}$ & Drainage & \\
\hline Red & Dikes cracked and leaking into surrounding areas & Drainage & \\
\hline $\begin{array}{l}\text { ISR-I } \\
\text { Component }\end{array}$ & ISR-I Sub Component & ISR-I Priority & \\
\hline $\begin{array}{l}\text { Centralized } \\
\text { Vehicle Wash } \\
\text { Facility }\end{array}$ & Area/Bay Space & High & \\
\hline ISR-I Rating & ISR-I Criteria & $\begin{array}{l}\text { BUILDER } \\
\text { Category }\end{array}$ & $\begin{array}{l}\text { BUILDER Sub } \\
\text { Issue }\end{array}$ \\
\hline Green & Area/Bays are sufficiently heated as required & $\begin{array}{l}\text { Size/Configur } \\
\text { ation }\end{array}$ & $\begin{array}{l}\text { Building } \\
\text { Configuration }\end{array}$ \\
\hline Red & Wash bays have inadequate space & $\begin{array}{l}\text { Size/Configur } \\
\text { ation }\end{array}$ & $\begin{array}{l}\text { Building } \\
\text { Configuration }\end{array}$ \\
\hline
\end{tabular}




\begin{tabular}{|c|c|c|c|}
\hline $\begin{array}{l}\text { ISR-I } \\
\text { Component }\end{array}$ & ISR-I Sub Component & ISR-I Priority & \\
\hline $\begin{array}{l}\text { Centralized } \\
\text { Vehicle Wash } \\
\text { Facility }\end{array}$ & Heating & High & \\
\hline ISR-I Rating & ISR-I Criteria & $\begin{array}{l}\text { BUILDER } \\
\text { Category }\end{array}$ & $\begin{array}{l}\text { BUILDER Sub } \\
\text { Issue }\end{array}$ \\
\hline Green & Area/Bays are sufficiently heated as required & Comfort & $\begin{array}{l}\text { HVAC Heating } \\
\text { Capacity }\end{array}$ \\
\hline Amber & Wash bay heating system damaged or insufficient & Comfort & $\begin{array}{l}\text { HVAC Heating } \\
\text { Capacity }\end{array}$ \\
\hline Red & required wast water-oil separator not installed & Comfort & $\begin{array}{l}\text { HVAC Heating } \\
\text { Capacity }\end{array}$ \\
\hline $\begin{array}{l}\text { ISR-I } \\
\text { Component }\end{array}$ & ISR-I Sub Component & ISR-I Priority & \\
\hline $\begin{array}{l}\text { Centralized } \\
\text { Vehicle Wash } \\
\text { Facility }\end{array}$ & Wastewater & High & \\
\hline ISR-I Rating & ISR-I Criteria & $\begin{array}{l}\text { BUILDER } \\
\text { Category }\end{array}$ & $\begin{array}{l}\text { BUILDER Sub } \\
\text { Issue }\end{array}$ \\
\hline Green & $\begin{array}{l}\text { Waste water is treated at the proper treatment } \\
\text { plant }\end{array}$ & Drainage & \\
\hline Amber & $\begin{array}{l}\text { Waste water collection system not fully meeting } \\
\text { facility needs }\end{array}$ & Drainage & \\
\hline Red & Waste water collection system not available & Drainage & \\
\hline $\begin{array}{l}\text { ISR-I } \\
\text { Component }\end{array}$ & ISR-I Sub Component & ISR-I Priority & \\
\hline $\begin{array}{l}\text { Centralized } \\
\text { Vehicle Wash } \\
\text { Facility }\end{array}$ & Overspray Screens & Medium & \\
\hline ISR-I Rating & ISR-I Criteria & $\begin{array}{l}\text { BUILDER } \\
\text { Category }\end{array}$ & $\begin{array}{l}\text { BUILDER Sub } \\
\text { Issue }\end{array}$ \\
\hline Green & Overspray screens installed as appropriate & $\begin{array}{l}\text { Missing/Im- } \\
\text { proper Comps }\end{array}$ & $\begin{array}{l}\text { Missing } \\
\text { Components? }\end{array}$ \\
\hline Amber & $\begin{array}{l}\text { Overspray screens installed between } 75 \% \text { of the } \\
\text { bays }\end{array}$ & $\begin{array}{l}\text { Missing/Im- } \\
\text { proper Comps }\end{array}$ & $\begin{array}{l}\text { Missing } \\
\text { Components? }\end{array}$ \\
\hline Red & No overspray screens installed & $\begin{array}{l}\text { Missing/Im- } \\
\text { proper Comps }\end{array}$ & $\begin{array}{l}\text { Missing } \\
\text { Components? }\end{array}$ \\
\hline $\begin{array}{l}\text { ISR-I } \\
\text { Component }\end{array}$ & ISR-I Sub Component & ISR-I Priority & \\
\hline $\begin{array}{l}\text { Centralized } \\
\text { Vehicle Wash } \\
\text { Facility }\end{array}$ & Walls & Medium & \\
\hline ISR-I Rating & ISR-I Criteria & $\begin{array}{l}\text { BUILDER } \\
\text { Category }\end{array}$ & $\begin{array}{l}\text { BUILDER Sub } \\
\text { Issue }\end{array}$ \\
\hline Green & $\begin{array}{l}\text { Walls composed of durable material (concrete, } \\
\text { wood, drywall, etc.) }\end{array}$ & $\begin{array}{l}\text { Structural } \\
\text { Adequacy }\end{array}$ & $\begin{array}{l}\text { Loading } \\
\text { Conditions }\end{array}$ \\
\hline Red & Walls NOT composed of durable material & $\begin{array}{l}\text { Structural } \\
\text { Adequacy }\end{array}$ & $\begin{array}{l}\text { Loading } \\
\text { Conditions }\end{array}$ \\
\hline
\end{tabular}




\begin{tabular}{|c|c|c|c|}
\hline $\begin{array}{l}\text { ISR-I } \\
\text { Component }\end{array}$ & ISR-I Sub Component & ISR-I Priority & \\
\hline $\begin{array}{l}\text { Centralized } \\
\text { Vehicle Wash } \\
\text { Facility }\end{array}$ & Lighting and Outlets & Low & \\
\hline ISR-I Rating & ISR-I Criteria & $\begin{array}{l}\text { BUILDER } \\
\text { Category }\end{array}$ & $\begin{array}{l}\text { BUILDER Sub } \\
\text { Issue }\end{array}$ \\
\hline Green & $\begin{array}{l}\text { All outlets grounded/GFI rated available where } \\
\text { water may be present }\end{array}$ & $\begin{array}{l}\text { Building } \\
\text { Services }\end{array}$ & $\begin{array}{l}\text { Electrical } \\
\text { Outlets }\end{array}$ \\
\hline Amber & $\begin{array}{l}\text { All outlets grounded/GFI rated available where } \\
\text { water may be present }\end{array}$ & $\begin{array}{l}\text { Building } \\
\text { Services }\end{array}$ & $\begin{array}{l}\text { Electrical } \\
\text { Outlets }\end{array}$ \\
\hline Red & $\begin{array}{l}\text { Ungrounded outlets or outlets where water may } \\
\text { be present are not GFI rated }\end{array}$ & $\begin{array}{l}\text { Building } \\
\text { Services }\end{array}$ & $\begin{array}{l}\text { Electrical } \\
\text { Outlets }\end{array}$ \\
\hline
\end{tabular}




\section{Appendix M: Army ISR-I mapping to BUILDER Functionality Criteria, Unit Operation Building}

\begin{tabular}{|c|c|c|c|}
\hline ISR-I Component & ISR-I Sub Component & ISR-I Priority & \\
\hline Sites and Grounds & Site and Grounds Lighting & High & \\
\hline ISR-I Rating & ISR-I Criteria & $\begin{array}{l}\text { BUILDER } \\
\text { Category }\end{array}$ & BUILDER Sub Issue \\
\hline Green & \multirow{6}{*}{$\begin{array}{l}\text { Pedestrian movement } \\
\text { Security } \\
\text { Signage } \\
\text { Landscape } \\
\text { Two or more of the } 4 \text { types of lighting in } \\
\text { the Green Column are missing } \\
\text { No site and ground lighting exists }\end{array}$} & Access & Building Entry \\
\hline Green & & Access & Building Entry \\
\hline Green & & Access & Building Entry \\
\hline Green & & Access & Building Entry \\
\hline Red & & Access & Building Entry \\
\hline Red & & Access & Building Entry \\
\hline ISR-I Component & ISR-I Sub Component & ISR-I Priority & \\
\hline Sites and Grounds & Disabled Access & High & \\
\hline ISR-I Rating & ISR-I Criteria & $\begin{array}{l}\text { BUILDER } \\
\text { Category }\end{array}$ & BUILDER Sub Issue \\
\hline Green & $\begin{array}{l}\text { Curb ramps are present wherever } \\
\text { accessible routes cross a curb }\end{array}$ & Accessibility & ABA compliance \\
\hline Green & Ramps are a minimum of 3 feet wide & Accessibility & ABA compliance \\
\hline Green & $\begin{array}{l}\text { Ramps have a moderate slope, not } \\
\text { exceeding a rise of } 1: 12 \text { inches } \\
\text { horizontally }\end{array}$ & Accessibility & ABA compliance \\
\hline Green & $\begin{array}{l}\text { Access across the site follows the shortest } \\
\text { accessible route to the facility }\end{array}$ & Accessibility & ABA compliance \\
\hline Amber & $\begin{array}{l}1 \text { or } 2 \text { of the } 4 \text { types of lighting in the } \\
\text { Green column missing }\end{array}$ & Accessibility & ABA compliance \\
\hline Red & $\begin{array}{l}\text { More than } 2 \text { of the accessible criteria } \\
\text { elements in the Green column are missing }\end{array}$ & Accessibility & ABA compliance \\
\hline ISR-I Component & ISR-I Sub Component & ISR-I Priority & \\
\hline Sites and Grounds & Turf and Pavement Drainage & High & \\
\hline ISR-I Rating & ISR-I Criteria & $\begin{array}{l}\text { BUILDER } \\
\text { Category }\end{array}$ & BUILDER Sub Issue \\
\hline Green & $\begin{array}{l}\text { No access the site that follows the } \\
\text { shortest accessible to the facility }\end{array}$ & Drainage & \\
\hline ISR-I Component & ISR-I Sub Component & ISR-I Priority & \\
\hline Sites and Grounds & Paved Sidewalks & Medium & \\
\hline ISR-I Rating & ISR-I Criteria & $\begin{array}{l}\text { BUILDER } \\
\text { Category }\end{array}$ & BUILDER Sub Issue \\
\hline Green & Installed from parking to facility & Access & Building Entry \\
\hline Green & Installed from adjacent streets to facility & Access & Building Entry \\
\hline
\end{tabular}




\begin{tabular}{|c|c|c|c|}
\hline Green & $\begin{array}{l}\text { At least } 4 \text { feet wide } \\
\text { Not installed from parking to facility } \\
\text { Not installed from streets to facility } \\
\text { Less than } 4 \text { feet wide } \\
\text { Not installed at all }\end{array}$ & Access & Building Entry \\
\hline Amber & \multirow{4}{*}{$\begin{array}{l}\text { Not installed from parking to facility } \\
\text { Not installed from streets to facility } \\
\text { Less than } 4 \text { feet wide } \\
\text { Not installed at all }\end{array}$} & Access & Building Entry \\
\hline Amber & & Access & Building Entry \\
\hline Amber & & Access & Building Entry \\
\hline Red & & Access & Building Entry \\
\hline ISR-I Component & ISR-I Sub Component & ISR-I Priority & \\
\hline Sites and Grounds & Landscaping & Medium & \\
\hline ISR-I Rating & ISR-I Criteria & $\begin{array}{l}\text { BUILDER } \\
\text { Category }\end{array}$ & BUILDER Sub Issue \\
\hline Green & $\begin{array}{l}\text { Displays a mixture of colorful plants and } \\
\text { greenery appropriate to the area }\end{array}$ & Aesthetics & Exterior Aesthetics \\
\hline Amber & Displays few color plantings or greenery & Aesthetics & Exterior Aesthetics \\
\hline Red & No plantings & Aesthetics & Exterior Aesthetics \\
\hline ISR-I Component & ISR-I Sub Component & ISR-I Priority & \\
\hline Sites and Grounds & Dumpster & Low & \\
\hline ISR-I Rating & ISR-I Criteria & $\begin{array}{l}\text { BUILDER } \\
\text { Category }\end{array}$ & BUILDER Sub Issue \\
\hline Green & $\begin{array}{l}\text { Screened by walls or landscaping to } \\
\text { obstruct view from Building occupants }\end{array}$ & Aesthetics & Exterior Aesthetics \\
\hline Green & $\begin{array}{l}\text { Screened by walls or landscaping to } \\
\text { obstruct view from Entrances }\end{array}$ & Aesthetics & Exterior Aesthetics \\
\hline Green & $\begin{array}{l}\text { Screened by walls or landscaping to } \\
\text { obstruct view from Streets }\end{array}$ & Aesthetics & Exterior Aesthetics \\
\hline Green & $\begin{array}{l}\text { Screened by walls or landscaping to } \\
\text { obstruct view from Parking Lots }\end{array}$ & Aesthetics & Exterior Aesthetics \\
\hline Green & $\begin{array}{l}33 \text { feet or more away from other occupied } \\
\text { buildings }\end{array}$ & Aesthetics & Exterior Aesthetics \\
\hline Green & $\begin{array}{l}82 \text { feet or more away from billeting or } \\
\text { housing }\end{array}$ & Aesthetics & Exterior Aesthetics \\
\hline Amber & $\begin{array}{l}\text { Not screened by walls or landscaping } \\
\text { sufficiently high to obscure view }\end{array}$ & Aesthetics & Exterior Aesthetics \\
\hline Amber & $\begin{array}{l}\text { More than } 20 \text { feet away, but less than } 33 \\
\text { feet away from other occupied facilities }\end{array}$ & Aesthetics & Exterior Aesthetics \\
\hline Amber & $\begin{array}{l}\text { More than } 50 \text { feet away, but less than } 82 \\
\text { feet away from billeting or housing }\end{array}$ & Aesthetics & Exterior Aesthetics \\
\hline Red & Not enclosed or screened from view & Aesthetics & Exterior Aesthetics \\
\hline Red & $\begin{array}{l}\text { Less than } 20 \text { feet away from other } \\
\text { occupied facilities }\end{array}$ & Aesthetics & Exterior Aesthetics \\
\hline Red & $\begin{array}{l}\text { Less than } 50 \text { feet away from billeting or } \\
\text { housing }\end{array}$ & Aesthetics & Exterior Aesthetics \\
\hline ISR-I Component & ISR-I Sub Component & ISR-I Priority & \\
\hline Parking & Disabled Parking & High & \\
\hline ISR-I Rating & ISR-I Criteria & $\begin{array}{l}\text { BUILDER } \\
\text { Category }\end{array}$ & BUILDER Sub Issue \\
\hline Green & $\begin{array}{l}\text { One of every } 25 \text { parking spaces is } \\
\text { designated for the disabled }\end{array}$ & Accessibility & ABA compliance \\
\hline
\end{tabular}




\begin{tabular}{|c|c|c|c|}
\hline Green & $\begin{array}{l}\text { For facilities mainly occupied by able- } \\
\text { bodied military personnel: }\end{array}$ & Accessibility & ABA compliance \\
\hline Green & $\begin{array}{l}\text { The 1:25 standard does not have to be } \\
\text { met, but spaces should be provided for } \\
\text { disabled personnel and visitors to facility }\end{array}$ & Accessibility & ABA compliance \\
\hline Green & $\begin{array}{l}\text { Accessible parking spaces are at least } 8 \\
\text { feet wide and have } 5 \text { additional feet for } \\
\text { exiting the car }\end{array}$ & Accessibility & ABA compliance \\
\hline Green & $\begin{array}{l}\text { Disabled parking is near the shortest } \\
\text { possible route to an accessible entrance }\end{array}$ & Accessibility & ABA compliance \\
\hline Green & $\begin{array}{l}\text { Accessible spaces are designated with } \\
\text { signs }\end{array}$ & Accessibility & ABA compliance \\
\hline Green & $\begin{array}{l}\text { Curb ramps are available wherever an } \\
\text { accessible route crosses a curb at a rise of } \\
\text { 1:12 or less }\end{array}$ & Accessibility & ABA compliance \\
\hline Green & $\begin{array}{l}\text { Ramps are available for disabled parking, } \\
\text { as needed, with maximum rise of } 1: 12\end{array}$ & Accessibility & ABA compliance \\
\hline Amber & $\begin{array}{l}\text { Meets } 1 \text { of the first two criteria in the } \\
\text { Green column, depending on facility use }\end{array}$ & Accessibility & ABA compliance \\
\hline Amber & $\begin{array}{l}\text { Accessible parking spaces are at least } 8 \\
\text { feet wide and have } 5 \text { additional feet for } \\
\text { exiting the car }\end{array}$ & Accessibility & ABA compliance \\
\hline Amber & $\begin{array}{l}\text { Meets } 2 \text { or } 3 \text { of the elements outlined in } \\
\text { the Green column }\end{array}$ & Accessibility & ABA compliance \\
\hline Red & $\begin{array}{l}\text { Neither of the first } 2 \text { criteria in the Green } \\
\text { column is met }\end{array}$ & Accessibility & ABA compliance \\
\hline Red & $\begin{array}{l}\text { Accessible parking spaces are at less than } \\
8 \text { feet wide or do not have } 5 \text { additional } \\
\text { feet for exiting the car }\end{array}$ & Accessibility & ABA compliance \\
\hline Red & $\begin{array}{l}\text { Meets } 1 \text { or none of the elements outlined } \\
\text { in the Green Column }\end{array}$ & Accessibility & ABA compliance \\
\hline ISR-I Component & ISR-I Sub Component & ISR-I Priority & \\
\hline Parking & Parking Availability & High & \\
\hline ISR-I Rating & ISR-I Criteria & $\begin{array}{l}\text { BUILDER } \\
\text { Category }\end{array}$ & BUILDER Sub Issue \\
\hline Green & $\begin{array}{l}\text { Parking spaces are available on the } \\
\text { installation for all personnel and visitors }\end{array}$ & Access & Building Entry \\
\hline Amber & $\begin{array}{l}\text { Parking spaces are available on the } \\
\text { installation for } 75 \%-99 \% \text { of personnel and } \\
\text { visitors }\end{array}$ & Access & Building Entry \\
\hline Red & $\begin{array}{l}\text { Parking spaces are available on the } \\
\text { installation for less than } 75 \% \text { of personnel } \\
\text { and visitors }\end{array}$ & Access & Building Entry \\
\hline ISR-I Component & ISR-I Sub Component & ISR-I Priority & \\
\hline Parking & Parking Area Standoff & High & \\
\hline ISR-I Rating & ISR-I Criteria & $\begin{array}{l}\text { BUILDER } \\
\text { Category }\end{array}$ & BUILDER Sub Issue \\
\hline Green & $\begin{array}{l}\text { Parking spaces are lovated } 82 \text { feet or } \\
\text { more away from occupied facilities }\end{array}$ & Access & Building Entry \\
\hline
\end{tabular}




\begin{tabular}{|c|c|c|c|}
\hline Green & $\begin{array}{l}\text { Within controlled perimeters, parking } \\
\text { spaces are located } 33 \text { feet or more away } \\
\text { from occupied facilities }\end{array}$ & Access & Building Entry \\
\hline Red & $\begin{array}{l}\text { Parking spaces are located less than } 82 \\
\text { feet away from occupied facilities }\end{array}$ & Access & Building Entry \\
\hline Red & $\begin{array}{l}\text { Within controlled perimeters, parking } \\
\text { spaces are located less than } 33 \text { feet from } \\
\text { occupied facilities }\end{array}$ & Access & Building Entry \\
\hline ISR-I Component & ISR-I Sub Component & ISR-I Priority & \\
\hline Parking & Parking Area Lighting & High & \\
\hline ISR-I Rating & ISR-I Criteria & $\begin{array}{l}\text { BUILDER } \\
\text { Category }\end{array}$ & BUILDER Sub Issue \\
\hline Green & Traffic flow during low visibility & Access & Building Entry \\
\hline Green & Pedestrian movement & Access & Building Entry \\
\hline Green & Signage & Access & Building Entry \\
\hline Amber & $\begin{array}{l}\text { Not more than } 1 \text { of the } 3 \text { types of lighting } \\
\text { in the Green column is missing }\end{array}$ & Access & Building Entry \\
\hline Red & $\begin{array}{l}\text { More than } 1 \text { of the } 3 \text { types of lighting in } \\
\text { the Green column is missing }\end{array}$ & Access & Building Entry \\
\hline ISR-I Component & ISR-I Sub Component & ISR-I Priority & \\
\hline Parking & Parking Pavement Drainage & High & \\
\hline ISR-I Rating & ISR-I Criteria & $\begin{array}{l}\text { BUILDER } \\
\text { Category }\end{array}$ & BUILDER Sub Issue \\
\hline Green & Sloped to drain & Drainage & \\
\hline Amber & Not well sloped to drain & Drainage & \\
\hline Red & Not draining & Drainage & \\
\hline ISR-I Component & ISR-I Sub Component & ISR-I Priority & \\
\hline Parking & Parking Spaces & Medium & \\
\hline ISR-I Rating & ISR-I Criteria & $\begin{array}{l}\text { BUILDER } \\
\text { Category }\end{array}$ & BUILDER Sub Issue \\
\hline Green & Spaces marked on pavement & Aesthetics & Exterior Aesthetics \\
\hline Green & Sized 8.5 feet wide by $16-18$ feet long & Aesthetics & Exterior Aesthetics \\
\hline Amber & $\begin{array}{l}\text { Spaces marked on pavement, but re- } \\
\text { stripping is needed }\end{array}$ & Aesthetics & Exterior Aesthetics \\
\hline Red & Spaces not identified & Aesthetics & Exterior Aesthetics \\
\hline Red & Less than 8.5 wide by $16-18$ long & Aesthetics & Exterior Aesthetics \\
\hline ISR-I Component & ISR-I Sub Component & ISR-I Priority & \\
\hline Parking & Parking Landscaping & Low & \\
\hline ISR-I Rating & ISR-I Criteria & $\begin{array}{l}\text { BUILDER } \\
\text { Category }\end{array}$ & BUILDER Sub Issue \\
\hline Green & $\begin{array}{l}\text { Displays a mixture of colorful plants and } \\
\text { greenery appropriate to the area }\end{array}$ & Aesthetics & Exterior Aesthetics \\
\hline Amber & $\begin{array}{l}\text { Displays few plantings of color and } \\
\text { greenery }\end{array}$ & Aesthetics & Exterior Aesthetics \\
\hline Red & No plantings & Aesthetics & Exterior Aesthetics \\
\hline ISR-I Component & ISR-I Sub Component & ISR-I Priority & \\
\hline
\end{tabular}




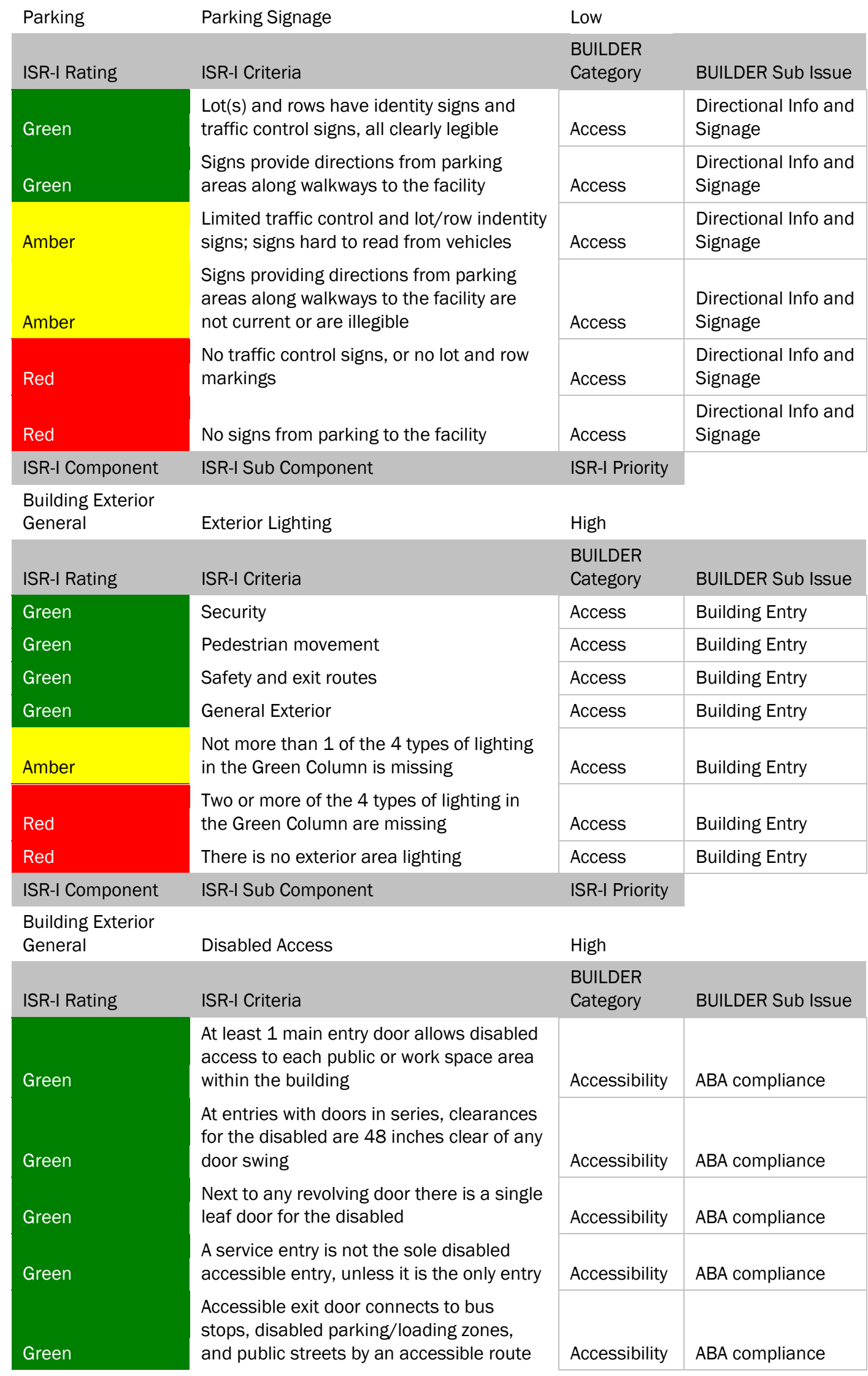




\begin{tabular}{|c|c|c|c|}
\hline Amber & $\begin{array}{l}3 \text { or more of the } 5 \text { conditions in the Green } \\
\text { column are met }\end{array}$ & Accessibility & ABA compliance \\
\hline Red & $\begin{array}{l}\text { Less than } 3 \text { of the } 5 \text { conditions in the } \\
\text { Green column are met }\end{array}$ & Accessibility & ABA compliance \\
\hline Red & Building is inaccessible to the disabled & Accessibility & ABA compliance \\
\hline ISR-I Component & ISR-I Sub Component & ISR-I Priority & \\
\hline $\begin{array}{l}\text { Building Exterior } \\
\text { General }\end{array}$ & Building Exterior Signage & Medium & \\
\hline ISR-I Rating & ISR-I Criteria & $\begin{array}{l}\text { BUILDER } \\
\text { Category }\end{array}$ & BUILDER Sub Issue \\
\hline Green & $\begin{array}{l}\text { Includes directions to parking, entrances, } \\
\text { and facilities }\end{array}$ & Access & $\begin{array}{l}\text { Directional Info and } \\
\text { Signage }\end{array}$ \\
\hline Amber & Not well coordinated but readable & Access & $\begin{array}{l}\text { Directional Info and } \\
\text { Signage }\end{array}$ \\
\hline Amber & $\begin{array}{l}\text { Missing directories to parking, entrances, } \\
\text { or facilities }\end{array}$ & Access & $\begin{array}{l}\text { Directional Info and } \\
\text { Signage }\end{array}$ \\
\hline Red & Directions not available & Access & $\begin{array}{l}\text { Directional Info and } \\
\text { Signage }\end{array}$ \\
\hline ISR-I Component & ISR-I Sub Component & ISR-I Priority & \\
\hline $\begin{array}{l}\text { Loading Dock / } \\
\text { Service Area }\end{array}$ & Lighting \& Outlets & High & \\
\hline ISR-I Rating & ISR-I Criteria & $\begin{array}{l}\text { BUILDER } \\
\text { Category }\end{array}$ & BUILDER Sub Issue \\
\hline Green & $\begin{array}{l}\text { Waterproof, Ground Fault Interrupt (GFI) } \\
\text { rated electrical outlets are available on the } \\
\text { loading dock and in the truck spotting area }\end{array}$ & $\begin{array}{l}\text { Building } \\
\text { Services }\end{array}$ & Electrical Outlets \\
\hline Amber & $\begin{array}{l}\text { Some outlets on the loading dock and } \\
\text { within the truck area are not waterproof or } \\
\text { GFI rated }\end{array}$ & $\begin{array}{l}\text { Building } \\
\text { Services }\end{array}$ & Electrical Outlets \\
\hline Red & $\begin{array}{l}\text { No waterproof or GFI rated outlets } \\
\text { available for the loading dock and truck } \\
\text { spotting areas }\end{array}$ & $\begin{array}{l}\text { Building } \\
\text { Services }\end{array}$ & Electrical Outlets \\
\hline ISR-I Component & ISR-I Sub Component & ISR-I Priority & \\
\hline $\begin{array}{l}\text { Loading Dock / } \\
\text { Service Area }\end{array}$ & Dock Boards and Station Lifts & High & \\
\hline ISR-I Rating & ISR-I Criteria & $\begin{array}{l}\text { BUILDER } \\
\text { Category }\end{array}$ & BUILDER Sub Issue \\
\hline Green & $\begin{array}{l}\text { Loading dock is sized to meet mission } \\
\text { requirements }\end{array}$ & $\begin{array}{l}\text { Size/Config } \\
\text { uration }\end{array}$ & $\begin{array}{l}\text { Building } \\
\text { Configuration }\end{array}$ \\
\hline Amber & $\begin{array}{l}\text { Loading dock exists, but it is not sized to } \\
\text { meet mission needs }\end{array}$ & $\begin{array}{l}\text { Size/Config } \\
\text { uration }\end{array}$ & $\begin{array}{l}\text { Building } \\
\text { Configuration }\end{array}$ \\
\hline Red & $\begin{array}{l}\text { No loading dock exists, although one is } \\
\text { required }\end{array}$ & $\begin{array}{l}\text { Size/Config } \\
\text { uration }\end{array}$ & $\begin{array}{l}\text { Building } \\
\text { Configuration }\end{array}$ \\
\hline ISR-I Component & ISR-I Sub Component & ISR-I Priority & \\
\hline $\begin{array}{l}\text { Loading Dock / } \\
\text { Service Area }\end{array}$ & Truck Area & High & \\
\hline ISR-I Rating & ISR-I Criteria & $\begin{array}{l}\text { BUILDER } \\
\text { Category }\end{array}$ & BUILDER Sub Issue \\
\hline
\end{tabular}




\begin{tabular}{|c|c|c|c|}
\hline Green & $\begin{array}{l}\text { Trucks have easy and safe access to } \\
\text { loading area and dock }\end{array}$ & $\begin{array}{l}\text { Size/Config } \\
\text { uration }\end{array}$ & $\begin{array}{l}\text { Building } \\
\text { Configuration }\end{array}$ \\
\hline Amber & $\begin{array}{l}\text { Truck access is safe, but has some space } \\
\text { restrictions }\end{array}$ & $\begin{array}{l}\text { Size/Config } \\
\text { uration }\end{array}$ & $\begin{array}{l}\text { Building } \\
\text { Configuration }\end{array}$ \\
\hline Red & $\begin{array}{l}\text { Unsafe truck accesss to service area and } \\
\text { dock space }\end{array}$ & $\begin{array}{l}\text { Size/Config } \\
\text { uration }\end{array}$ & $\begin{array}{l}\text { Building } \\
\text { Configuration }\end{array}$ \\
\hline ISR-I Component & ISR-I Sub Component & ISR-I Priority & \\
\hline $\begin{array}{l}\text { Loading Dock / } \\
\text { Service Area }\end{array}$ & Service Doors & Medium & \\
\hline ISR-I Rating & ISR-I Criteria & $\begin{array}{l}\text { BUILDER } \\
\text { Category }\end{array}$ & BUILDER Sub Issue \\
\hline Green & $\begin{array}{l}\text { Service and personnel doors are large } \\
\text { enough for easy access }\end{array}$ & Access & Building Entry \\
\hline Amber & $\begin{array}{l}\text { Service and personnel doors provide } \\
\text { limited access }\end{array}$ & Access & Building Entry \\
\hline Red & $\begin{array}{l}\text { Service and personnel doors provide } \\
\text { inadequate access }\end{array}$ & Access & Building Entry \\
\hline ISR-I Component & ISR-I Sub Component & ISR-I Priority & \\
\hline Lobby & Lobby Area & High & \\
\hline ISR-I Rating & ISR-I Criteria & $\begin{array}{l}\text { BUILDER } \\
\text { Category }\end{array}$ & BUILDER Sub Issue \\
\hline Green & Space layout meets mission needs & $\begin{array}{l}\text { Size/Config } \\
\text { uration }\end{array}$ & $\begin{array}{l}\text { Building } \\
\text { Configuration }\end{array}$ \\
\hline Amber & $\begin{array}{l}\text { Space layout restricts movement in lobby } \\
\text { or restricts mission needs }\end{array}$ & $\begin{array}{l}\text { Size/Config } \\
\text { uration }\end{array}$ & $\begin{array}{l}\text { Building } \\
\text { Configuration }\end{array}$ \\
\hline Red & $\begin{array}{l}\text { Space layout is inadequate to fulfill } \\
\text { mission needs }\end{array}$ & $\begin{array}{l}\text { Size/Config } \\
\text { uration }\end{array}$ & $\begin{array}{l}\text { Building } \\
\text { Configuration }\end{array}$ \\
\hline ISR-I Component & ISR-I Sub Component & ISR-I Priority & \\
\hline Lobby & Lighting \& Outlets & High & \\
\hline ISR-I Rating & ISR-I Criteria & $\begin{array}{l}\text { BUILDER } \\
\text { Category }\end{array}$ & BUILDER Sub Issue \\
\hline Green & $\begin{array}{l}\text { At least one electrical duplex outlet (three } \\
\text { prong grounded) on all wall surfaces }\end{array}$ & $\begin{array}{l}\text { Building } \\
\text { Services }\end{array}$ & Electrical Outlets \\
\hline Amber & $\begin{array}{l}\text { One or more walls lack grounded duplex } \\
\text { outlets }\end{array}$ & $\begin{array}{l}\text { Building } \\
\text { Services }\end{array}$ & Electrical Outlets \\
\hline Red & No grounded duplex outlets in lobby & $\begin{array}{l}\text { Building } \\
\text { Services }\end{array}$ & Electrical Outlets \\
\hline ISR-I Component & ISR-I Sub Component & ISR-I Priority & \\
\hline Lobby & Interior Doors & Medium & \\
\hline ISR-I Rating & ISR-I Criteria & $\begin{array}{l}\text { BUILDER } \\
\text { Category }\end{array}$ & BUILDER Sub Issue \\
\hline Green & $\begin{array}{l}\text { Allow access by the disabled to public or } \\
\text { work spaces in the facility }\end{array}$ & Accessibility & ABA compliance \\
\hline Green & $\begin{array}{l}\text { Interior doors that are also fire/exit doors, } \\
\text { and normally in an open position, are } \\
\text { equipped with automatic closure devices } \\
\text { and panic hardware }\end{array}$ & $\begin{array}{l}\text { Missing/Im- } \\
\text { proper } \\
\text { Comps }\end{array}$ & $\begin{array}{l}\text { Missing } \\
\text { Components? }\end{array}$ \\
\hline
\end{tabular}




\begin{tabular}{|c|c|c|c|}
\hline Green & $\begin{array}{l}\text { Panic hardware does not require a key or } \\
\text { special tools to open from inside }\end{array}$ & $\begin{array}{l}\text { Missing/Im- } \\
\text { proper } \\
\text { Comps }\end{array}$ & $\begin{array}{l}\text { Missing } \\
\text { Components? }\end{array}$ \\
\hline Red & $\begin{array}{l}\text { Do not allow access by the disabled to } \\
\text { public or work spaces in the facility }\end{array}$ & Accessibility & ABA compliance \\
\hline \multirow[t]{2}{*}{ Red } & $\begin{array}{l}\text { Interior doors that are also fire/exit doors, } \\
\text { and normally in an open position, are not } \\
\text { equipped with automatic closure devices } \\
\text { and/or panic hardware }\end{array}$ & $\begin{array}{l}\text { Missing/Im- } \\
\text { proper } \\
\text { Comps }\end{array}$ & $\begin{array}{l}\text { Missing } \\
\text { Components? }\end{array}$ \\
\hline & $\begin{array}{l}\text { Panic hardware requires a key or special } \\
\text { tools to open from inside }\end{array}$ & $\begin{array}{l}\text { Missing/Im- } \\
\text { proper } \\
\text { Comps }\end{array}$ & $\begin{array}{l}\text { Missing } \\
\text { Components? }\end{array}$ \\
\hline ISR-I Component & ISR-I Sub Component & ISR-I Priority & \\
\hline Lobby & Telephone System & Medium & \\
\hline ISR-I Rating & ISR-I Criteria & $\begin{array}{l}\text { BUILDER } \\
\text { Category }\end{array}$ & BUILDER Sub Issue \\
\hline Green & $\begin{array}{l}\text { Enough telephone jacks are available to } \\
\text { support current mission requirements }\end{array}$ & $\begin{array}{l}\text { Building } \\
\text { Services }\end{array}$ & Telephone System \\
\hline Amber & Not enough telephone jacks are available & $\begin{array}{l}\text { Building } \\
\text { Services }\end{array}$ & Telephone System \\
\hline Red & $\begin{array}{l}\text { If required, telephone jacks are not } \\
\text { available }\end{array}$ & $\begin{array}{l}\text { Building } \\
\text { Services }\end{array}$ & Telephone System \\
\hline ISR-I Component & ISR-I Sub Component & ISR-I Priority & \\
\hline Lobby & Computer LAN System & Medium & \\
\hline ISR-I Rating & ISR-I Criteria & $\begin{array}{l}\text { BUILDER } \\
\text { Category }\end{array}$ & BUILDER Sub Issue \\
\hline Green & $\begin{array}{l}\text { Enough LAN outlets are available to } \\
\text { support mission requirements }\end{array}$ & $\begin{array}{l}\text { Building } \\
\text { Services }\end{array}$ & Building IT System \\
\hline Amber & Not enough LAN outlets are available & $\begin{array}{l}\text { Building } \\
\text { Services }\end{array}$ & Building IT System \\
\hline Red & If required, LAN outlets are not available & $\begin{array}{l}\text { Building } \\
\text { Services }\end{array}$ & Building IT System \\
\hline ISR-I Component & ISR-I Sub Component & ISR-I Priority & \\
\hline Lobby & Signage & Low & \\
\hline ISR-I Rating & ISR-I Criteria & $\begin{array}{l}\text { BUILDER } \\
\text { Category }\end{array}$ & BUILDER Sub Issue \\
\hline Green & $\begin{array}{l}\text { Present and current; includes a building } \\
\text { directory }\end{array}$ & Access & $\begin{array}{l}\text { Directional Info and } \\
\text { Signage }\end{array}$ \\
\hline Amber & $\begin{array}{l}\text { Present, but not current; does not include } \\
\text { a building directory }\end{array}$ & Access & $\begin{array}{l}\text { Directional Info and } \\
\text { Signage }\end{array}$ \\
\hline Red & No present & Access & $\begin{array}{l}\text { Directional Info and } \\
\text { Signage }\end{array}$ \\
\hline ISR-I Component & ISR-I Sub Component & ISR-I Priority & \\
\hline Corridors & Corridor Transit Area & High & \\
\hline ISR-I Rating & ISR-I Criteria & $\begin{array}{l}\text { BUILDER } \\
\text { Category }\end{array}$ & BUILDER Sub Issue \\
\hline Green & Minimum of 4 feet wide & $\begin{array}{l}\text { Size/Config } \\
\text { uration }\end{array}$ & $\begin{array}{l}\text { Building } \\
\text { Configuration }\end{array}$ \\
\hline
\end{tabular}




\begin{tabular}{|c|c|c|c|}
\hline Green & Fire extinguishers in secure boxes & $\begin{array}{l}\text { Missing/Im- } \\
\text { proper } \\
\text { Comps }\end{array}$ & $\begin{array}{l}\text { Missing } \\
\text { Components? }\end{array}$ \\
\hline \multirow[t]{2}{*}{ Amber } & \multirow[t]{2}{*}{$\begin{array}{l}\text { Corridors meet } 2 \text { of the } 3 \text { bulleted } \\
\text { elements }\end{array}$} & $\begin{array}{l}\text { Missing/Im- } \\
\text { proper } \\
\text { Comps }\end{array}$ & $\begin{array}{l}\text { Missing } \\
\text { Components? }\end{array}$ \\
\hline & & $\begin{array}{l}\text { Missing/Im- } \\
\text { proper } \\
\text { Comps }\end{array}$ & $\begin{array}{l}\text { Missing } \\
\text { Components? }\end{array}$ \\
\hline ISR-I Component & ISR-I Sub Component & ISR-I Priority & \\
\hline Corridors & Lighting \& Outlets & High & \\
\hline ISR-I Rating & ISR-I Criteria & $\begin{array}{l}\text { BUILDER } \\
\text { Category }\end{array}$ & BUILDER Sub Issue \\
\hline Green & $\begin{array}{l}\text { At least one electrical duplex (three prong } \\
\text { grounded) outlet on all wall surfaces }\end{array}$ & $\begin{array}{l}\text { Building } \\
\text { Services }\end{array}$ & Electrical Outlets \\
\hline Amber & $\begin{array}{l}\text { One or more walls lack grounded duplex } \\
\text { outlets }\end{array}$ & $\begin{array}{l}\text { Building } \\
\text { Services }\end{array}$ & Electrical Outlets \\
\hline Red & No grounded duplex outlets in Lobby, or & $\begin{array}{l}\text { Building } \\
\text { Services }\end{array}$ & Electrical Outlets \\
\hline ISR-I Component & ISR-I Sub Component & ISR-I Priority & \\
\hline Corridors & Corridor Doors & Medium & \\
\hline ISR-I Rating & ISR-I Criteria & $\begin{array}{l}\text { BUILDER } \\
\text { Category }\end{array}$ & BUILDER Sub Issue \\
\hline Green & $\begin{array}{l}\text { Allow access by the disabled to public or } \\
\text { work spaces in the facility }\end{array}$ & Accessibility & ABA compliance \\
\hline Green & $\begin{array}{l}\text { Interior doors that are also fire/exit doors, } \\
\text { and normally in an open position, are } \\
\text { equipped with automatic closure devices } \\
\text { and panic hardware }\end{array}$ & $\begin{array}{l}\text { Missing/Im- } \\
\text { proper } \\
\text { Comps }\end{array}$ & $\begin{array}{l}\text { Missing } \\
\text { Components? }\end{array}$ \\
\hline Green & $\begin{array}{l}\text { Interior doors that exit to the exterior are } \\
\text { metal or solid core wood and open easily } \\
\text { from the inside }\end{array}$ & Access & Building Entry \\
\hline Green & $\begin{array}{l}\text { Panic hardware does not require a key or } \\
\text { special tools to open from inside. }\end{array}$ & $\begin{array}{l}\text { Missing/Im- } \\
\text { proper } \\
\text { Comps }\end{array}$ & $\begin{array}{l}\text { Missing } \\
\text { Components? }\end{array}$ \\
\hline Red & $\begin{array}{l}\text { Does not allow access by the disabled to } \\
\text { public or work spaces in the facility }\end{array}$ & Accessibility & ABA compliance \\
\hline Red & $\begin{array}{l}\text { Interior doors that are also fire/exit doors, } \\
\text { and normally in an open position, are not } \\
\text { equipped with automatic closure devices } \\
\text { and/or panic hardware }\end{array}$ & $\begin{array}{l}\text { Missing/Im- } \\
\text { proper } \\
\text { Comps }\end{array}$ & $\begin{array}{l}\text { Missing } \\
\text { Components? }\end{array}$ \\
\hline Red & $\begin{array}{l}\text { Interior doors that exit to the exterior are } \\
\text { not metal or solid core wood or do not } \\
\text { open easily from the inside }\end{array}$ & Access & Building Entry \\
\hline Red & $\begin{array}{l}\text { Panic hardware requires a key or special } \\
\text { tools to open from inside }\end{array}$ & $\begin{array}{l}\text { Missing/Im- } \\
\text { proper } \\
\text { Comps }\end{array}$ & $\begin{array}{l}\text { Missing } \\
\text { Components? }\end{array}$ \\
\hline ISR-I Component & ISR-I Sub Component & ISR-I Priority & \\
\hline Stairs & Stair Doors & High & \\
\hline
\end{tabular}




\begin{tabular}{|c|c|c|c|}
\hline ISR-I Rating & ISR-I Criteria & $\begin{array}{l}\text { BUILDER } \\
\text { Category }\end{array}$ & BUILDER Sub Issue \\
\hline \multirow[t]{2}{*}{ Green } & \multirow[t]{2}{*}{$\begin{array}{l}\text { Panic hardware does not require key or } \\
\text { special tools to operate from inside }\end{array}$} & $\begin{array}{l}\text { Missing/Im- } \\
\text { proper } \\
\text { Comps }\end{array}$ & $\begin{array}{l}\text { Missing } \\
\text { Components? }\end{array}$ \\
\hline & & $\begin{array}{l}\text { Missing/Im- } \\
\text { proper } \\
\text { Comps }\end{array}$ & $\begin{array}{l}\text { Missing } \\
\text { Components? }\end{array}$ \\
\hline ISR-I Component & ISR-I Sub Component & ISR-I Priority & \\
\hline Stairs & Lighitng and Outlets & High & \\
\hline ISR-I Rating & ISR-I Criteria & $\begin{array}{l}\text { BUILDER } \\
\text { Category }\end{array}$ & BUILDER Sub Issue \\
\hline Green & \multirow{3}{*}{$\begin{array}{l}\text { If required, there is at least on GFI outlet } \\
\text { at each floor landing } \\
\text { If required, there is at least one GFI outlet } \\
\text { at each floor landing } \\
\text { Although required, there is no outlet at } \\
\text { each floor landing }\end{array}$} & $\begin{array}{l}\text { Building } \\
\text { Services }\end{array}$ & Electrical Outlets \\
\hline Amber & & $\begin{array}{l}\text { Building } \\
\text { Services }\end{array}$ & Electrical Outlets \\
\hline Red & & $\begin{array}{l}\text { Building } \\
\text { Services }\end{array}$ & Electrical Outlets \\
\hline ISR-I Component & ISR-I Sub Component & ISR-I Priority & \\
\hline Elevators & Saftey Standards & High & \\
\hline ISR-I Rating & ISR-I Criteria & $\begin{array}{l}\text { BUILDER } \\
\text { Category }\end{array}$ & BUILDER Sub Issue \\
\hline Green & \multirow{2}{*}{$\begin{array}{l}\text { Firefighter key control available } \\
\text { Controls and signals work and } \\
\text { accommodate the disabled }\end{array}$} & $\begin{array}{l}\text { Missing/Im- } \\
\text { proper } \\
\text { Comps }\end{array}$ & $\begin{array}{l}\text { Missing } \\
\text { Components? }\end{array}$ \\
\hline Green & & Accessibility & ABA compliance \\
\hline ISR-I Component & ISR-I Sub Component & ISR-I Priority & \\
\hline Elevators & Capacity & High & \\
\hline ISR-I Rating & ISR-I Criteria & $\begin{array}{l}\text { BUILDER } \\
\text { Category }\end{array}$ & BUILDER Sub Issue \\
\hline Green & \multirow{3}{*}{$\begin{array}{l}\text { Number and size of elevators support } \\
\text { population served } \\
\text { Number and size of elevators support } 75 \% \\
\text { of population served } \\
\text { Number and size of elevators support less } \\
\text { than } 75 \% \text { of population served }\end{array}$} & $\begin{array}{l}\text { Size/Config } \\
\text { uration }\end{array}$ & $\begin{array}{l}\text { Building } \\
\text { Configuration }\end{array}$ \\
\hline Amber & & $\begin{array}{l}\text { Size/Config } \\
\text { uration }\end{array}$ & $\begin{array}{l}\text { Building } \\
\text { Configuration }\end{array}$ \\
\hline Red & & $\begin{array}{l}\text { Size/Config } \\
\text { uration }\end{array}$ & $\begin{array}{l}\text { Building } \\
\text { Configuration }\end{array}$ \\
\hline ISR-I Component & ISR-I Sub Component & ISR-I Priority & \\
\hline Escalators & Safety Standards & High & \\
\hline ISR-I Rating & ISR-I Criteria & $\begin{array}{l}\text { BUILDER } \\
\text { Category }\end{array}$ & BUILDER Sub Issue \\
\hline \multirow[t]{2}{*}{ Green } & \multirow{2}{*}{$\begin{array}{l}\text { Width is minimum of } 32 \text { inches } \\
\text { Escalators conform to only } 1 \text { of the saftey } \\
\text { standards in the Green column }\end{array}$} & $\begin{array}{l}\text { Size/Config } \\
\text { uration }\end{array}$ & $\begin{array}{l}\text { Building } \\
\text { Configuration }\end{array}$ \\
\hline & & $\begin{array}{l}\text { Size/Config } \\
\text { uration }\end{array}$ & $\begin{array}{l}\text { Building } \\
\text { Configuration }\end{array}$ \\
\hline ISR-I Component & ISR-I Sub Component & ISR-I Priority & \\
\hline Escalators & Signage & Low & \\
\hline
\end{tabular}




\begin{tabular}{|c|c|c|c|}
\hline ISR-I Rating & ISR-I Criteria & $\begin{array}{l}\text { BUILDER } \\
\text { Category }\end{array}$ & BUILDER Sub Issue \\
\hline \multirow[t]{2}{*}{ Green } & Well placed for easy location of escalators & Access & $\begin{array}{l}\text { Directional Info and } \\
\text { Signage }\end{array}$ \\
\hline & Highly visible and readable & Access & $\begin{array}{l}\text { Directional Info and } \\
\text { Signage }\end{array}$ \\
\hline Amber & Signage is available, but not well placed & Access & $\begin{array}{l}\text { Directional Info and } \\
\text { Signage }\end{array}$ \\
\hline Amber & \multirow[t]{2}{*}{ Hard to read } & Access & $\begin{array}{l}\text { Directional Info and } \\
\text { Signage }\end{array}$ \\
\hline Red & & Access & $\begin{array}{l}\text { Directional Info and } \\
\text { Signage }\end{array}$ \\
\hline ISR-I Component & ISR-I Sub Component & ISR-I Priority & \\
\hline $\begin{array}{l}\text { Administrative } \\
\text { Areas }\end{array}$ & Work Area & \multicolumn{2}{|l|}{ High } \\
\hline ISR-I Rating & ISR-I Criteria & $\begin{array}{l}\text { BUILDER } \\
\text { Category }\end{array}$ & BUILDER Sub Issue \\
\hline \multirow[b]{2}{*}{ Green } & \multirow{2}{*}{$\begin{array}{l}\text { Flexible layout; space meets mission } \\
\text { needs } \\
\text { Sufficient storage space, close to work } \\
\text { stations, meets mission needs }\end{array}$} & $\begin{array}{l}\text { Size/Config } \\
\text { uration }\end{array}$ & $\begin{array}{l}\text { Building } \\
\text { Configuration }\end{array}$ \\
\hline & & $\begin{array}{l}\text { Size/Config } \\
\text { uration }\end{array}$ & $\begin{array}{l}\text { Building } \\
\text { Configuration }\end{array}$ \\
\hline Amber & \multirow{2}{*}{$\begin{array}{l}\text { Space restricts aisle and workstation } \\
\text { layout } \\
\text { Marginal storage space, not close to } \\
\text { workstations, but meets mission needs }\end{array}$} & $\begin{array}{l}\text { Size/Config } \\
\text { uration }\end{array}$ & $\begin{array}{l}\text { Building } \\
\text { Configuration }\end{array}$ \\
\hline Amber & & $\begin{array}{l}\text { Size/Config } \\
\text { uration }\end{array}$ & $\begin{array}{l}\text { Building } \\
\text { Configuration }\end{array}$ \\
\hline \multirow[t]{2}{*}{ Red } & \multirow{2}{*}{$\begin{array}{l}\text { Workstation layout does not meet needs } \\
\text { Little to no storage space; hinders } \\
\text { effective operations }\end{array}$} & $\begin{array}{l}\text { Size/Config } \\
\text { uration }\end{array}$ & $\begin{array}{l}\text { Building } \\
\text { Configuration }\end{array}$ \\
\hline & & $\begin{array}{l}\text { Size/Config } \\
\text { uration }\end{array}$ & $\begin{array}{l}\text { Building } \\
\text { Configuration }\end{array}$ \\
\hline ISR-I Component & ISR-I Sub Component & ISR-I Priority & \\
\hline \multicolumn{3}{|l|}{ Administrative } & \\
\hline ISR-I Rating & ISR-I Criteria & $\begin{array}{l}\text { BUILDER } \\
\text { Category }\end{array}$ & BUILDER Sub Issue \\
\hline \multirow[t]{2}{*}{ Green } & \multirow{2}{*}{$\begin{array}{l}\text { At least one electrical duplex (three prong } \\
\text { grounded) outlet at all workstations } \\
\text { Besides workstations, there is at least one } \\
\text { electrical duplex outlet on all interior walls } \\
\text { of the area }\end{array}$} & $\begin{array}{l}\text { Building } \\
\text { Services }\end{array}$ & Electrical Outlets \\
\hline & & $\begin{array}{l}\text { Building } \\
\text { Services }\end{array}$ & Electrical Outlets \\
\hline \multirow[t]{2}{*}{ Amber } & \multirow{4}{*}{$\begin{array}{l}\text { One or more walls lack grounded duplex } \\
\text { outlets } \\
\text { Besides workstations, there is at least one } \\
\text { electrical duplex outlet on } 1 \text { wall of the } \\
\text { area } \\
\text { No grounded duplex outlets at } \\
\text { workstations } \\
\text { No additional electrical outlets other than } \\
\text { those at workstations }\end{array}$} & $\begin{array}{l}\text { Building } \\
\text { Services }\end{array}$ & Electrical Outlets \\
\hline & & $\begin{array}{l}\text { Building } \\
\text { Services }\end{array}$ & Electrical Outlets \\
\hline \multirow[t]{2}{*}{ Red } & & $\begin{array}{l}\text { Building } \\
\text { Services }\end{array}$ & Electrical Outlets \\
\hline & & $\begin{array}{l}\text { Building } \\
\text { Services }\end{array}$ & Electrical Outlets \\
\hline ISR-I Component & ISR-I Sub Component & ISR-I Priority & \\
\hline
\end{tabular}




\begin{tabular}{|c|c|c|c|}
\hline $\begin{array}{l}\text { Administrative } \\
\text { Areas }\end{array}$ & Computer/LAN system & \multicolumn{2}{|l|}{ High } \\
\hline ISR-I Rating & ISR-I Criteria & $\begin{array}{l}\text { BUILDER } \\
\text { Category }\end{array}$ & BUILDER Sub Issue \\
\hline Green & $\begin{array}{l}\text { Enough LAN outlets are available to } \\
\text { support current mission requirements }\end{array}$ & $\begin{array}{l}\text { Building } \\
\text { Services }\end{array}$ & Building IT System \\
\hline Amber & Not enough LAN outlets are available & $\begin{array}{l}\text { Building } \\
\text { Services }\end{array}$ & Building IT System \\
\hline Red & If required, LAN outlets are not available & $\begin{array}{l}\text { Building } \\
\text { Services }\end{array}$ & Building IT System \\
\hline ISR-I Component & ISR-I Sub Component & ISR-I Priority & \\
\hline $\begin{array}{l}\text { Administrative } \\
\text { Areas }\end{array}$ & Telephone System & High & \\
\hline ISR-I Rating & ISR-I Criteria & $\begin{array}{l}\text { BUILDER } \\
\text { Category }\end{array}$ & BUILDER Sub Issue \\
\hline Green & $\begin{array}{l}\text { Enough telephone jacks are available to } \\
\text { support current mission requirements }\end{array}$ & $\begin{array}{l}\text { Building } \\
\text { Services }\end{array}$ & Telephone System \\
\hline Amber & Not enough telephone jacks are available & $\begin{array}{l}\text { Building } \\
\text { Services }\end{array}$ & Telephone System \\
\hline Red & $\begin{array}{l}\text { If required telephone jacks are not } \\
\text { available }\end{array}$ & $\begin{array}{l}\text { Building } \\
\text { Services }\end{array}$ & Telephone System \\
\hline ISR-I Component & ISR-I Sub Component & ISR-I Priority & \\
\hline $\begin{array}{l}\text { Administrative } \\
\text { Areas }\end{array}$ & Interior Doors & Medium & \\
\hline ISR-I Rating & ISR-I Criteria & $\begin{array}{l}\text { BUILDER } \\
\text { Category }\end{array}$ & BUILDER Sub Issue \\
\hline $\begin{array}{l}\text { Red } \\
\text { Red }\end{array}$ & $\begin{array}{l}\text { Do not allow access by the disabled to } \\
\text { public or work spaces in the facility } \\
\text { Doors that exit to the exterior are not } \\
\text { equipped with fire/exit signs and panic } \\
\text { hardware }\end{array}$ & $\begin{array}{l}\text { Accessibility } \\
\text { Accessibility }\end{array}$ & $\begin{array}{l}\text { ABA compliance } \\
\text { ABA compliance }\end{array}$ \\
\hline ISR-I Component & ISR-I Sub Component & ISR-I Priority & \\
\hline Bathrooms & Ventilation & High & \\
\hline ISR-I Rating & ISR-I Criteria & $\begin{array}{l}\text { BUILDER } \\
\text { Category }\end{array}$ & BUILDER Sub Issue \\
\hline Green & $\begin{array}{l}\text { Ventilation integrated into forced air } \\
\text { system }\end{array}$ & Comfort & $\begin{array}{l}\text { Ventilation } \\
\text { Capacity }\end{array}$ \\
\hline Amber & $\begin{array}{l}\text { Fans provided, but not integrated into } \\
\text { forced air system }\end{array}$ & Comfort & $\begin{array}{l}\text { Ventilation } \\
\text { Capacity }\end{array}$ \\
\hline Red & Poor or no ventilation & Comfort & $\begin{array}{l}\text { Ventilation } \\
\text { Capacity }\end{array}$ \\
\hline ISR-I Component & ISR-I Sub Component & ISR-I Priority & \\
\hline Bathrooms & Toilets/Sinks Availability & High & \\
\hline ISR-I Rating & ISR-I Criteria & $\begin{array}{l}\text { BUILDER } \\
\text { Category }\end{array}$ & BUILDER Sub Issue \\
\hline Green & $\begin{array}{l}\text { Number of stalls, urinals, and sinks satisfy } \\
\text { population served }\end{array}$ & $\begin{array}{l}\text { Building } \\
\text { Services }\end{array}$ & Plumbing Fixtures \\
\hline
\end{tabular}




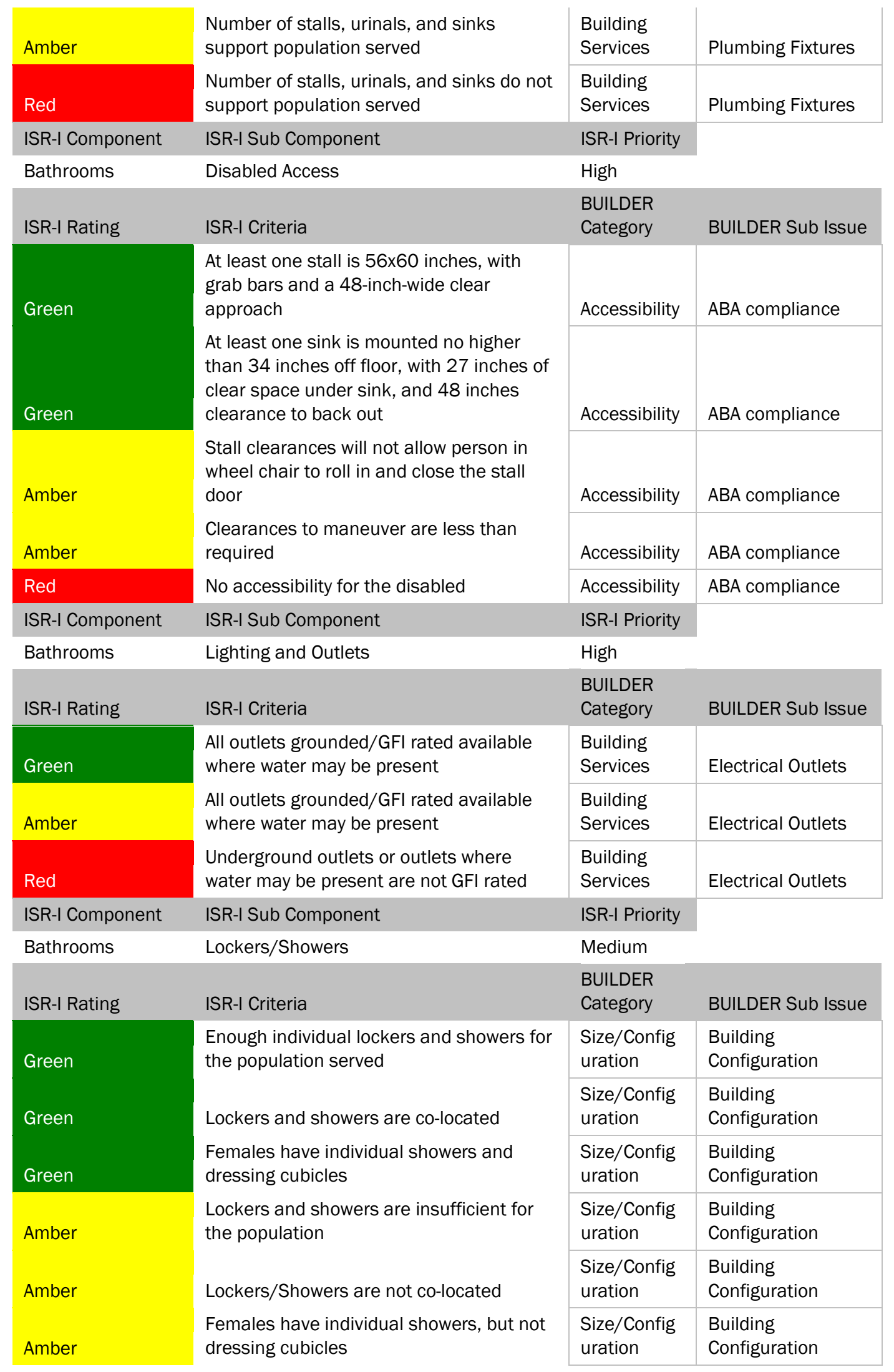




\begin{tabular}{|c|c|c|c|}
\hline Red & No locker room or showers available & $\begin{array}{l}\text { Size/Config } \\
\text { uration }\end{array}$ & $\begin{array}{l}\text { Building } \\
\text { Configuration }\end{array}$ \\
\hline ISR-I Component & ISR-I Sub Component & ISR-I Priority & \\
\hline Bathrooms & Bathroom Accessories & Low & \\
\hline ISR-I Rating & ISR-I Criteria & $\begin{array}{l}\text { BUILDER } \\
\text { Category }\end{array}$ & BUILDER Sub Issue \\
\hline Green & $\begin{array}{l}\text { Dispensers for hand soap, towels, toilet } \\
\text { paper, disposal containers for hygiene } \\
\text { products, etc., are present and easily } \\
\text { accessible }\end{array}$ & $\begin{array}{l}\text { Missing/Im- } \\
\text { proper } \\
\text { Comps }\end{array}$ & $\begin{array}{l}\text { Missing } \\
\text { Components? }\end{array}$ \\
\hline Amber & $\begin{array}{l}\text { Accessories are available, but difficult to } \\
\text { access }\end{array}$ & $\begin{array}{l}\text { Missing/Im- } \\
\text { proper } \\
\text { Comps }\end{array}$ & $\begin{array}{l}\text { Missing } \\
\text { Components? }\end{array}$ \\
\hline Red & Accessories are not available & $\begin{array}{l}\text { Missing/Im- } \\
\text { proper } \\
\text { Comps }\end{array}$ & $\begin{array}{l}\text { Missing } \\
\text { Components? }\end{array}$ \\
\hline ISR-I Component & ISR-I Sub Component & ISR-I Priority & \\
\hline Arms Room & Arms Room Security & High & \\
\hline ISR-I Rating & ISR-I Criteria & $\begin{array}{l}\text { BUILDER } \\
\text { Category }\end{array}$ & BUILDER Sub Issue \\
\hline Green & Intrusion Detection System (IDS) & $\begin{array}{l}\text { Building } \\
\text { Services }\end{array}$ & Security System \\
\hline Green & $\begin{array}{l}\text { Has independent uniterrupted power } \\
\text { supply of at least four hours }\end{array}$ & $\begin{array}{l}\text { Building } \\
\text { Services }\end{array}$ & $\begin{array}{l}\text { Uninterruptible } \\
\text { Power Supply }\end{array}$ \\
\hline Green & Connected to a central reporting location & $\begin{array}{l}\text { Building } \\
\text { Services }\end{array}$ & Security System \\
\hline Green & $\begin{array}{l}\text { Meets requirements for certified arms } \\
\text { rooms security. Arms vault certification } \\
\text { available, has been executed within the } \\
\text { last five years }\end{array}$ & $\begin{array}{l}\text { Building } \\
\text { Services }\end{array}$ & Security System \\
\hline Green & $\begin{array}{l}\text { Class } V \text { door with day gate (day gate not } \\
\text { required for ARNG) }\end{array}$ & $\begin{array}{l}\text { Building } \\
\text { Services }\end{array}$ & Security System \\
\hline Green & Working $24 \times 7$ light at the arms vault door & $\begin{array}{l}\text { Building } \\
\text { Services }\end{array}$ & Security System \\
\hline Amber & $\begin{array}{l}\text { Class } \vee \text { vault door, but no day gate (day } \\
\text { gate not required for ARNG) }\end{array}$ & $\begin{array}{l}\text { Building } \\
\text { Services }\end{array}$ & Security System \\
\hline Red & $\begin{array}{l}\text { No IDS; weapons storage requires } 24 \text { hour } \\
\text { guard }\end{array}$ & $\begin{array}{l}\text { Building } \\
\text { Services }\end{array}$ & Security System \\
\hline Red & No class V vault door & $\begin{array}{l}\text { Building } \\
\text { Services }\end{array}$ & Security System \\
\hline Red & No security light over arms vault door & $\begin{array}{l}\text { Building } \\
\text { Services }\end{array}$ & Security System \\
\hline ISR-I Component & ISR-I Sub Component & ISR-I Priority & \\
\hline Arms Room & Lighting and Outlets & High & \\
\hline ISR-I Rating & ISR-I Criteria & $\begin{array}{l}\text { BUILDER } \\
\text { Category }\end{array}$ & BUILDER Sub Issue \\
\hline Green & $\begin{array}{l}\text { At least one electrical duplex (three prong } \\
\text { grounded) outlet on all walls }\end{array}$ & $\begin{array}{l}\text { Building } \\
\text { Services }\end{array}$ & Electrical Outlets \\
\hline
\end{tabular}




\begin{tabular}{|c|c|c|c|}
\hline Green & $\begin{array}{l}\text { Arms Room light switches are inside the } \\
\text { arms room }\end{array}$ & $\begin{array}{l}\text { Building } \\
\text { Services }\end{array}$ & Electrical Outlets \\
\hline Amber & $\begin{array}{l}\text { One or more walls do not have grounded } \\
\text { duplex outlets }\end{array}$ & $\begin{array}{l}\text { Building } \\
\text { Services }\end{array}$ & Electrical Outlets \\
\hline \multirow[t]{2}{*}{ Red } & \multirow{2}{*}{$\begin{array}{l}\text { No grounded outlets in arms area } \\
\text { Arms Room light switches are not inside } \\
\text { the arms room }\end{array}$} & $\begin{array}{l}\text { Building } \\
\text { Services }\end{array}$ & Electrical Outlets \\
\hline & & $\begin{array}{l}\text { Building } \\
\text { Services }\end{array}$ & Electrical Outlets \\
\hline ISR-I Component & ISR-I Sub Component & ISR-I Priority & \\
\hline Arms Room & Ventilation & High & \\
\hline ISR-I Rating & ISR-I Criteria & $\begin{array}{l}\text { BUILDER } \\
\text { Category }\end{array}$ & BUILDER Sub Issue \\
\hline \multirow{2}{*}{$\begin{array}{l}\text { Green } \\
\text { Green }\end{array}$} & \multirow{5}{*}{$\begin{array}{l}\text { Integrated into the forced air system } \\
\text { Dehumidifier present, if required } \\
\text { Fans, but not part of forced air system }\end{array}$} & Comfort & $\begin{array}{l}\text { Ventilation } \\
\text { Capacity }\end{array}$ \\
\hline & & Comfort & Dehumidification \\
\hline Amber & & Comfort & $\begin{array}{l}\text { Ventilation } \\
\text { Capacity }\end{array}$ \\
\hline \multirow{2}{*}{$\begin{array}{l}\text { Red } \\
\text { Red }\end{array}$} & & Comfort & $\begin{array}{l}\text { Ventilation } \\
\text { Capacity }\end{array}$ \\
\hline & & Comfort & Dehumidification \\
\hline ISR-I Component & ISR-I Sub Component & ISR-I Priority & \\
\hline Arms Room & Arms Room Work Area & Medium & \\
\hline ISR-I Rating & ISR-I Criteria & $\begin{array}{l}\text { BUILDER } \\
\text { Category }\end{array}$ & BUILDER Sub Issue \\
\hline \multirow[t]{2}{*}{ Green } & \multirow{3}{*}{$\begin{array}{l}\text { Separate caged/vault area for assigned } \\
\text { units } \\
\text { Adjacent/adequately sized area for } \\
\text { weapons maintenance } \\
\text { Fire extinguisher, with inspection tag } \\
\text { present }\end{array}$} & $\begin{array}{l}\text { Size/Config } \\
\text { uration }\end{array}$ & $\begin{array}{l}\text { Building } \\
\text { Configuration }\end{array}$ \\
\hline & & $\begin{array}{l}\text { Size/Config } \\
\text { uration }\end{array}$ & $\begin{array}{l}\text { Building } \\
\text { Configuration }\end{array}$ \\
\hline Green & & $\begin{array}{l}\text { Size/Config } \\
\text { uration }\end{array}$ & $\begin{array}{l}\text { Building } \\
\text { Configuration }\end{array}$ \\
\hline \multirow[t]{2}{*}{ Amber } & \multirow{4}{*}{$\begin{array}{l}\text { Not enough caged/vault areas for units } \\
\text { Inadequately sized area for weapons } \\
\text { maintenance } \\
\text { No separate cages/vaults, a single } \\
\text { cage/vault only } \\
\text { No provisions for weapons maintenance in } \\
\text { vicinity or arms room }\end{array}$} & $\begin{array}{l}\text { Size/Config } \\
\text { uration }\end{array}$ & $\begin{array}{l}\text { Building } \\
\text { Configuration }\end{array}$ \\
\hline & & $\begin{array}{l}\text { Size/Config } \\
\text { uration }\end{array}$ & $\begin{array}{l}\text { Building } \\
\text { Configuration }\end{array}$ \\
\hline \multirow[t]{2}{*}{ Red } & & $\begin{array}{l}\text { Size/Config } \\
\text { uration }\end{array}$ & $\begin{array}{l}\text { Building } \\
\text { Configuration }\end{array}$ \\
\hline & & $\begin{array}{l}\text { Size/Config } \\
\text { uration }\end{array}$ & $\begin{array}{l}\text { Building } \\
\text { Configuration }\end{array}$ \\
\hline ISR-I Component & ISR-I Sub Component & ISR-I Priority & \\
\hline Arms Room & Weapons Storage & Medium & \\
\hline ISR-I Rating & ISR-I Criteria & $\begin{array}{l}\text { BUILDER } \\
\text { Category }\end{array}$ & BUILDER Sub Issue \\
\hline \multirow[t]{3}{*}{ Green } & \multirow{3}{*}{$\begin{array}{l}\text { Adequate weapons storage } \\
\text { Racking arranged to provide easy access } \\
\text { for quick distribution } \\
\text { No storage, or inadequate storage for } \\
\text { units assigned weapons }\end{array}$} & $\begin{array}{l}\text { Size/Config } \\
\text { uration }\end{array}$ & $\begin{array}{l}\text { Building } \\
\text { Configuration }\end{array}$ \\
\hline & & $\begin{array}{l}\text { Size/Config } \\
\text { uration }\end{array}$ & $\begin{array}{l}\text { Building } \\
\text { Configuration }\end{array}$ \\
\hline & & $\begin{array}{l}\text { Size/Config } \\
\text { uration }\end{array}$ & $\begin{array}{l}\text { Building } \\
\text { Configuration }\end{array}$ \\
\hline
\end{tabular}




\begin{tabular}{|c|c|c|c|}
\hline Red & $\begin{array}{l}\text { No racks present for weapons, or not } \\
\text { enough racks for weapons. Individual } \\
\text { and/or crew served weapons not racked } \\
\text { properly; some on tables or floors due to } \\
\text { lack of specialty racks }\end{array}$ & $\begin{array}{l}\text { Size/Config } \\
\text { uration }\end{array}$ & $\begin{array}{l}\text { Building } \\
\text { Configuration }\end{array}$ \\
\hline ISR-I Component & ISR-I Sub Component & ISR-I Priority & \\
\hline Arms Room & Ceilings & Medium & \\
\hline ISR-I Rating & ISR-I Criteria & $\begin{array}{l}\text { BUILDER } \\
\text { Category }\end{array}$ & BUILDER Sub Issue \\
\hline Green & Reinforced concrete & $\begin{array}{l}\text { Structural } \\
\text { Adequacy }\end{array}$ & Loading Conditions \\
\hline Red & Ceiling is not reinforced concrete & $\begin{array}{l}\text { Structural } \\
\text { Adequacy }\end{array}$ & Loading Conditions \\
\hline ISR-I Component & ISR-I Sub Component & ISR-I Priority & \\
\hline Arms Room & Floors & Medium & \\
\hline ISR-I Rating & ISR-I Criteria & $\begin{array}{l}\text { BUILDER } \\
\text { Category }\end{array}$ & BUILDER Sub Issue \\
\hline Green & Reinforced concrete & $\begin{array}{l}\text { Structural } \\
\text { Adequacy }\end{array}$ & Loading Conditions \\
\hline Red & Flooring is not reinforced concrete & $\begin{array}{l}\text { Structural } \\
\text { Adequacy }\end{array}$ & Loading Conditions \\
\hline ISR-I Component & ISR-I Sub Component & ISR-I Priority & \\
\hline Arms Room & Walls & Medium & \\
\hline ISR-I Rating & ISR-I Criteria & $\begin{array}{l}\text { BUILDER } \\
\text { Category }\end{array}$ & BUILDER Sub Issue \\
\hline Green & $\begin{array}{l}\text { Are reinforced with concrete or concrete } \\
\text { block walls with rebar and concrete filled } \\
\text { cavities }\end{array}$ & $\begin{array}{l}\text { Structural } \\
\text { Adequacy }\end{array}$ & Loading Conditions \\
\hline Green & $\begin{array}{l}\text { Arms room wall conduits are externally } \\
\text { mounted; painted/covered to match wall }\end{array}$ & Aesthetics & Interior Aesthetics \\
\hline Green & $\begin{array}{l}\text { Conduits in weapons maintenance area } \\
\text { walls are concealed within the walls }\end{array}$ & Aesthetics & Interior Aesthetics \\
\hline Amber & $\begin{array}{l}\text { Conduits in weapons maintenance walls } \\
\text { are exposed; painted/covered to match } \\
\text { wall }\end{array}$ & Aesthetics & Interior Aesthetics \\
\hline Red & $\begin{array}{l}\text { Walls are not concrete or reinforced } \\
\text { concrete block }\end{array}$ & $\begin{array}{l}\text { Structural } \\
\text { Adequacy }\end{array}$ & Loading Conditions \\
\hline Red & $\begin{array}{l}\text { Arms room wall conduits are exposed, do } \\
\text { not match wall color }\end{array}$ & Aesthetics & Interior Aesthetics \\
\hline Red & $\begin{array}{l}\text { Weapons maintenance area wall conduits } \\
\text { are exposed, do not match wall color }\end{array}$ & Aesthetics & Interior Aesthetics \\
\hline ISR-I Component & ISR-I Sub Component & ISR-I Priority & \\
\hline Arms Room & Windows and Other Openings & Medium & \\
\hline ISR-I Rating & ISR-I Criteria & $\begin{array}{l}\text { BUILDER } \\
\text { Category }\end{array}$ & BUILDER Sub Issue \\
\hline Green & $\begin{array}{l}\text { Windows, if present, are sealed with } \\
\text { materials comparable to that forming the } \\
\text { adjacent walls }\end{array}$ & Aesthetics & Interior Aesthetics \\
\hline
\end{tabular}




\begin{tabular}{|c|c|c|c|}
\hline Green & $\begin{array}{l}\text { Vents, ducts and other openings of } 96 \\
\text { square inches or more will be equipped } \\
\text { with steel bars or steel mesh so that } \\
\text { openings do not exceed } 32 \text { square inches }\end{array}$ & $\begin{array}{l}\text { Missing/Im- } \\
\text { proper } \\
\text { Comps }\end{array}$ & $\begin{array}{l}\text { Missing } \\
\text { Components? }\end{array}$ \\
\hline \multirow[t]{2}{*}{ Red } & $\begin{array}{l}\text { Windows are not sealed to match the } \\
\text { requirements outlined in the Green } \\
\text { column }\end{array}$ & Aesthetics & Interior Aesthetics \\
\hline & $\begin{array}{l}\text { column } \\
\text { Vents, ducts and other openings are not } \\
\text { secured as outlined in the Green column }\end{array}$ & $\begin{array}{l}\text { Missing/Im- } \\
\text { proper } \\
\text { Comps }\end{array}$ & $\begin{array}{l}\text { Missing } \\
\text { Components? }\end{array}$ \\
\hline ISR-I Component & ISR-I Sub Component & ISR-I Priority & \\
\hline Arms Room & Doors & Medium & \\
\hline ISR-I Rating & ISR-I Criteria & $\begin{array}{l}\text { BUILDER } \\
\text { Category }\end{array}$ & BUILDER Sub Issue \\
\hline \multirow[t]{2}{*}{ Green } & \multirow{2}{*}{$\begin{array}{l}\text { Non-Vault doors have lever handles and } \\
\text { kick plates } \\
\text { Weapons maintenance area doors that } \\
\text { exit directly to the exterior are equipped } \\
\text { with fire exit signs and panic hardware }\end{array}$} & $\begin{array}{l}\text { Missing/Im- } \\
\text { proper } \\
\text { Comps }\end{array}$ & $\begin{array}{l}\text { Missing } \\
\text { Components? }\end{array}$ \\
\hline & & $\begin{array}{l}\text { Missing/Im- } \\
\text { proper } \\
\text { Comps }\end{array}$ & $\begin{array}{l}\text { Missing } \\
\text { Components? }\end{array}$ \\
\hline Amber & \multirow{2}{*}{$\begin{array}{l}\text { Non-Vault doors do not have lever handle } \\
\text { and kick plates } \\
\text { Weapons maintenance area doors that } \\
\text { exit directly to the exterior are not } \\
\text { equipped with fire exit signs and panic } \\
\text { hardware }\end{array}$} & $\begin{array}{l}\text { Missing/Im- } \\
\text { proper } \\
\text { Comps }\end{array}$ & $\begin{array}{l}\text { Missing } \\
\text { Components? }\end{array}$ \\
\hline Red & & $\begin{array}{l}\text { Missing/Im- } \\
\text { proper } \\
\text { Comps }\end{array}$ & $\begin{array}{l}\text { Missing } \\
\text { Components? }\end{array}$ \\
\hline ISR-I Component & ISR-I Sub Component & ISR-I Priority & \\
\hline Arms Room & Computer/LAN System & Medium & \\
\hline ISR-I Rating & ISR-I Criteria & $\begin{array}{l}\text { BUILDER } \\
\text { Category }\end{array}$ & BUILDER Sub Issue \\
\hline Green & Enough LAN outlets to support mission & $\begin{array}{l}\text { Building } \\
\text { Services }\end{array}$ & Building IT System \\
\hline Amber & \multirow[t]{2}{*}{ Not enough LAN outlets are available } & $\begin{array}{l}\text { Building } \\
\text { Services }\end{array}$ & Building IT System \\
\hline Red & & $\begin{array}{l}\text { Building } \\
\text { Services }\end{array}$ & Building IT System \\
\hline ISR-I Component & ISR-I Sub Component & ISR-I Priority & \\
\hline Arms Room & Telephone & Medium & \\
\hline ISR-I Rating & ISR-I Criteria & $\begin{array}{l}\text { BUILDER } \\
\text { Category }\end{array}$ & BUILDER Sub Issue \\
\hline Green & At least one telephone jack in arms room & $\begin{array}{l}\text { Building } \\
\text { Services }\end{array}$ & Telephone System \\
\hline Amber & \multirow[t]{2}{*}{ Not enough telephone jacks are available } & $\begin{array}{l}\text { Building } \\
\text { Services }\end{array}$ & Telephone System \\
\hline Red & & $\begin{array}{l}\text { Building } \\
\text { Services }\end{array}$ & Telephone System \\
\hline ISR-I Component & ISR-I Sub Component & ISR-I Priority & \\
\hline Arms Room & Signage & Low & \\
\hline
\end{tabular}




\begin{tabular}{|c|c|c|c|}
\hline ISR-I Rating & ISR-I Criteria & $\begin{array}{l}\text { BUILDER } \\
\text { Category }\end{array}$ & BUILDER Sub Issue \\
\hline Green & \multirow{3}{*}{$\begin{array}{l}\text { Coordinated for safety and movement } \\
\text { Minimal and not clearly visible, hindering } \\
\text { safety and movement }\end{array}$} & Access & $\begin{array}{l}\text { Directional Info and } \\
\text { Signage }\end{array}$ \\
\hline Amber & & Access & $\begin{array}{l}\text { Directional Info and } \\
\text { Signage }\end{array}$ \\
\hline Red & & Access & $\begin{array}{l}\text { Directional Info and } \\
\text { Signage }\end{array}$ \\
\hline ISR-I Component & ISR-I Sub Component & ISR-I Priority & \\
\hline Classroom & Space Layout & High & \\
\hline ISR-I Rating & ISR-I Criteria & $\begin{array}{l}\text { BUILDER } \\
\text { Category }\end{array}$ & BUILDER Sub Issue \\
\hline \multirow[t]{2}{*}{ Green } & \multirow{2}{*}{$\begin{array}{l}\text { Flexible layout, space meets mission } \\
\text { requirements } \\
\text { Sufficient storage space meets mission } \\
\text { needs }\end{array}$} & $\begin{array}{l}\text { Size/Config } \\
\text { uration }\end{array}$ & $\begin{array}{l}\text { Building } \\
\text { Configuration }\end{array}$ \\
\hline & & $\begin{array}{l}\text { Size/Config } \\
\text { uration }\end{array}$ & $\begin{array}{l}\text { Building } \\
\text { Configuration }\end{array}$ \\
\hline Amber & \multirow{2}{*}{$\begin{array}{l}\text { Space restricts operations } \\
\text { Marginal storage space, but meets } \\
\text { mission needs }\end{array}$} & $\begin{array}{l}\text { Size/Config } \\
\text { uration }\end{array}$ & $\begin{array}{l}\text { Building } \\
\text { Configuration }\end{array}$ \\
\hline Amber & & $\begin{array}{l}\text { Size/Config } \\
\text { uration }\end{array}$ & $\begin{array}{l}\text { Building } \\
\text { Configuration }\end{array}$ \\
\hline \multirow[t]{2}{*}{ Red } & \multirow{2}{*}{$\begin{array}{l}\text { Layout does not meet mission needs } \\
\text { Little to no storage space; hinders } \\
\text { effective operations }\end{array}$} & $\begin{array}{l}\text { Size/Config } \\
\text { uration }\end{array}$ & $\begin{array}{l}\text { Building } \\
\text { Configuration }\end{array}$ \\
\hline & & $\begin{array}{l}\text { Size/Config } \\
\text { uration }\end{array}$ & $\begin{array}{l}\text { Building } \\
\text { Configuration }\end{array}$ \\
\hline ISR-I Component & ISR-I Sub Component & ISR-I Priority & \\
\hline Classroom & Audio Visual (A/V) & High & \\
\hline ISR-I Rating & ISR-I Criteria & $\begin{array}{l}\text { BUILDER } \\
\text { Category }\end{array}$ & BUILDER Sub Issue \\
\hline Green & $\begin{array}{l}\text { Space fully accomodates current A/V } \\
\text { equipment/aids }\end{array}$ & $\begin{array}{l}\text { Size/Config } \\
\text { uration }\end{array}$ & $\begin{array}{l}\text { Building } \\
\text { Configuration }\end{array}$ \\
\hline Green & No obstruction to view $\mathrm{A} / \mathrm{V}$ is evident & $\begin{array}{l}\text { Size/Config } \\
\text { uration }\end{array}$ & $\begin{array}{l}\text { Building } \\
\text { Configuration }\end{array}$ \\
\hline Green & $\begin{array}{l}\text { Specific lighting and window coverage to } \\
\text { present an environment for ease of } \\
\text { viewing }\end{array}$ & Comfort & Building Lighting \\
\hline \multirow[t]{2}{*}{ Amber } & \multirow{2}{*}{$\begin{array}{l}\text { Space provides limited ability to } \\
\text { accommodate current } \mathrm{A} / \mathrm{V} \\
\text { equipment/aids } \\
\text { Obstruction prevents observation of visual } \\
\text { aids for some personnel }\end{array}$} & $\begin{array}{l}\text { Size/Config } \\
\text { uration }\end{array}$ & $\begin{array}{l}\text { Building } \\
\text { Configuration }\end{array}$ \\
\hline & & $\begin{array}{l}\text { Size/Config } \\
\text { uration }\end{array}$ & $\begin{array}{l}\text { Building } \\
\text { Configuration }\end{array}$ \\
\hline Amber & \multirow{4}{*}{$\begin{array}{l}\text { Lighting and window coverage limits } \\
\text { creation of dark environment for viewing } \\
\text { Space does not accommodate A/V } \\
\text { equipment/aids } \\
\text { Obstructions are overly disruptive for } \\
\text { observation of visual aids } \\
\text { No capability to darken the room to aid in } \\
\text { viewing }\end{array}$} & Comfort & Building Lighting \\
\hline Red & & $\begin{array}{l}\text { Size/Config } \\
\text { uration }\end{array}$ & $\begin{array}{l}\text { Building } \\
\text { Configuration }\end{array}$ \\
\hline Red & & $\begin{array}{l}\text { Size/Config } \\
\text { uration }\end{array}$ & $\begin{array}{l}\text { Building } \\
\text { Configuration }\end{array}$ \\
\hline Red & & Comfort & Building Lighting \\
\hline
\end{tabular}




\begin{tabular}{|c|c|c|c|}
\hline ISR-I Component & ISR-I Sub Component & ISR-I Priority & \\
\hline Classroom & Lighitng and Outlets & High & \\
\hline ISR-I Rating & ISR-I Criteria & $\begin{array}{l}\text { BUILDER } \\
\text { Category }\end{array}$ & BUILDER Sub Issue \\
\hline \multirow[t]{2}{*}{ Green } & \multirow{2}{*}{$\begin{array}{l}\text { At least one electrical duplex (three prong } \\
\text { grounded) outlet at all stations } \\
\text { Besides workstations, there is at least } 1 \\
\text { electrical duplex outlet on all interior walls }\end{array}$} & $\begin{array}{l}\text { Building } \\
\text { Services }\end{array}$ & Electrical Outlets \\
\hline & & $\begin{array}{l}\text { Building } \\
\text { Services }\end{array}$ & Electrical Outlets \\
\hline Amber & \multirow{2}{*}{$\begin{array}{l}\text { One or more workstations lack grounded } \\
\text { duplex outlets } \\
\text { Besides workstations, there is at least one } \\
\text { electrical duplex outlet on } 1 \text { wall of area }\end{array}$} & $\begin{array}{l}\text { Building } \\
\text { Services }\end{array}$ & Electrical Outlets \\
\hline Amber & & $\begin{array}{l}\text { Building } \\
\text { Services }\end{array}$ & Electrical Outlets \\
\hline \multirow[t]{2}{*}{ Red } & \multirow{2}{*}{$\begin{array}{l}\text { No grounded outlets at workstations } \\
\text { No additional electrical outlets other than } \\
\text { those at workstations }\end{array}$} & $\begin{array}{l}\text { Building } \\
\text { Services }\end{array}$ & Electrical Outlets \\
\hline & & $\begin{array}{l}\text { Building } \\
\text { Services }\end{array}$ & Electrical Outlets \\
\hline ISR-I Component & ISR-I Sub Component & ISR-I Priority & \\
\hline Classroom & Computer/LAN System & Medium & \\
\hline ISR-I Rating & ISR-I Criteria & $\begin{array}{l}\text { BUILDER } \\
\text { Category }\end{array}$ & BUILDER Sub Issue \\
\hline Green & $\begin{array}{l}\text { Enough LAN outelts are available to } \\
\text { support current mission requirements }\end{array}$ & $\begin{array}{l}\text { Building } \\
\text { Services }\end{array}$ & Building IT System \\
\hline Amber & \multirow[t]{2}{*}{ Not enough LAN outlets are available } & $\begin{array}{l}\text { Building } \\
\text { Services }\end{array}$ & Building IT System \\
\hline Red & & $\begin{array}{l}\text { Building } \\
\text { Services }\end{array}$ & Building IT System \\
\hline ISR-I Component & ISR-I Sub Component & ISR-I Priority & \\
\hline Conference Room & Space Layout & High & \\
\hline ISR-I Rating & ISR-I Criteria & $\begin{array}{l}\text { BUILDER } \\
\text { Category }\end{array}$ & BUILDER Sub Issue \\
\hline \multirow[t]{2}{*}{ Green } & \multirow{2}{*}{$\begin{array}{l}\text { Flexible layout, space meets mission } \\
\text { requirements } \\
\text { Sufficient storage space meets mission } \\
\text { needs }\end{array}$} & $\begin{array}{l}\text { Size/Config } \\
\text { uration }\end{array}$ & $\begin{array}{l}\text { Building } \\
\text { Configuration }\end{array}$ \\
\hline & & $\begin{array}{l}\text { Size/Config } \\
\text { uration }\end{array}$ & $\begin{array}{l}\text { Building } \\
\text { Configuration }\end{array}$ \\
\hline Amber & \multirow{4}{*}{$\begin{array}{l}\text { Space restricts layout } \\
\text { Marginal storage space, but meets } \\
\text { mission needs }\end{array}$} & $\begin{array}{l}\text { Size/Config } \\
\text { uration }\end{array}$ & $\begin{array}{l}\text { Building } \\
\text { Configuration }\end{array}$ \\
\hline Amber & & $\begin{array}{l}\text { Size/Config } \\
\text { uration }\end{array}$ & $\begin{array}{l}\text { Building } \\
\text { Configuration }\end{array}$ \\
\hline \multirow[t]{2}{*}{ Red } & & $\begin{array}{l}\text { Size/Config } \\
\text { uration }\end{array}$ & $\begin{array}{l}\text { Building } \\
\text { Configuration }\end{array}$ \\
\hline & & $\begin{array}{l}\text { Size/Config } \\
\text { uration }\end{array}$ & $\begin{array}{l}\text { Building } \\
\text { Configuration }\end{array}$ \\
\hline ISR-I Component & ISR-I Sub Component & ISR-I Priority & \\
\hline Conference Room & Telephone System & High & \\
\hline ISR-I Rating & ISR-I Criteria & $\begin{array}{l}\text { BUILDER } \\
\text { Category }\end{array}$ & BUILDER Sub Issue \\
\hline Green & $\begin{array}{l}\text { Enough telephone jacks are available to } \\
\text { support current mission requirements }\end{array}$ & $\begin{array}{l}\text { Building } \\
\text { Services }\end{array}$ & Telephone System \\
\hline
\end{tabular}




\begin{tabular}{|c|c|c|c|}
\hline Amber & \multirow{2}{*}{$\begin{array}{l}\text { Not enough telephone jacks are available } \\
\text { If required telephone jacks are not } \\
\text { available }\end{array}$} & $\begin{array}{l}\text { Building } \\
\text { Services }\end{array}$ & Telephone System \\
\hline Red & & $\begin{array}{l}\text { Building } \\
\text { Services }\end{array}$ & Telephone System \\
\hline ISR-I Component & ISR-I Sub Component & ISR-I Priority & \\
\hline Conference Room & Variable Lighting & High & \\
\hline ISR-I Rating & ISR-I Criteria & $\begin{array}{l}\text { BUILDER } \\
\text { Category }\end{array}$ & BUILDER Sub Issue \\
\hline Green & Variable lighting is in place & Comfort & Building Lighting \\
\hline Green & $\begin{array}{l}\text { Provides bright lighting in key areas to } \\
\text { include sitting areas and writing surfaces }\end{array}$ & Comfort & Building Lighting \\
\hline Green & $\begin{array}{l}\text { Lighting has capability to segment room } \\
\text { for use of projector or other audio visual }\end{array}$ & Comfort & Building Lighting \\
\hline Amber & Provides limited lighting to key areas & Comfort & Building Lighting \\
\hline Amber & $\begin{array}{l}\text { Lighting has limited capacity to segment } \\
\text { the room for use of projector or other } \mathrm{A} / \mathrm{V}\end{array}$ & Comfort & Building Lighting \\
\hline Red & No variable lighting in the room & Comfort & Building Lighting \\
\hline Red & Variable lighting is inoperative & Comfort & Building Lighting \\
\hline Red & $\begin{array}{l}\text { Unable to adjust appropriately to meet the } \\
\text { needs of users }\end{array}$ & Comfort & Building Lighting \\
\hline ISR-I Component & ISR-I Sub Component & ISR-I Priority & \\
\hline Conference Room & Audio Visual (A/V) & High & \\
\hline ISR-I Rating & ISR-I Criteria & $\begin{array}{l}\text { BUILDER } \\
\text { Category }\end{array}$ & BUILDER Sub Issue \\
\hline Green & $\begin{array}{l}\text { Space fully accomodates current A/V } \\
\text { equipment/aids }\end{array}$ & $\begin{array}{l}\text { Size/Config } \\
\text { uration }\end{array}$ & $\begin{array}{l}\text { Building } \\
\text { Configuration }\end{array}$ \\
\hline Green & No obstruction to view $\mathrm{A} / \mathrm{V}$ is evident & $\begin{array}{l}\text { Size/Config } \\
\text { uration }\end{array}$ & $\begin{array}{l}\text { Building } \\
\text { Configuration }\end{array}$ \\
\hline Green & $\begin{array}{l}\text { Specific lighting and window coverage to } \\
\text { present an environment for ease of } \\
\text { viewing }\end{array}$ & Comfort & Building Lighting \\
\hline Amber & $\begin{array}{l}\text { Space provides limited ability to } \\
\text { accommodate current } \mathrm{A} / \mathrm{V} \\
\text { equipment/aids }\end{array}$ & $\begin{array}{l}\text { Size/Config } \\
\text { uration }\end{array}$ & $\begin{array}{l}\text { Building } \\
\text { Configuration }\end{array}$ \\
\hline Amber & $\begin{array}{l}\text { Obstruction prevents observation of visual } \\
\text { aids for some personnel }\end{array}$ & $\begin{array}{l}\text { Size/Config } \\
\text { uration }\end{array}$ & $\begin{array}{l}\text { Building } \\
\text { Configuration }\end{array}$ \\
\hline Amber & $\begin{array}{l}\text { Lighting and window coverage limits } \\
\text { creation of dark environment for viewing }\end{array}$ & Comfort & Building Lighting \\
\hline Red & $\begin{array}{l}\text { Space does not accommodate A/V } \\
\text { equipment/aids }\end{array}$ & $\begin{array}{l}\text { Size/Config } \\
\text { uration }\end{array}$ & $\begin{array}{l}\text { Building } \\
\text { Configuration }\end{array}$ \\
\hline Red & $\begin{array}{l}\text { Obstructions are overly disruptive for } \\
\text { observation of visual aids }\end{array}$ & $\begin{array}{l}\text { Size/Config } \\
\text { uration }\end{array}$ & $\begin{array}{l}\text { Building } \\
\text { Configuration }\end{array}$ \\
\hline Red & $\begin{array}{l}\text { No capability to darken the room to aid in } \\
\text { viewing }\end{array}$ & Comfort & Building Lighting \\
\hline ISR-I Component & ISR-I Sub Component & ISR-I Priority & \\
\hline Conference Room & Security & High & \\
\hline ISR-I Rating & ISR-I Criteria & $\begin{array}{l}\text { BUILDER } \\
\text { Category }\end{array}$ & BUILDER Sub Issue \\
\hline
\end{tabular}




\begin{tabular}{|c|c|c|c|}
\hline Green & $\begin{array}{l}\text { The room can be secured for confidential } \\
\text { or classified briefings in accordance with } \\
\text { appropriate security classification guide }\end{array}$ & $\begin{array}{l}\text { Building } \\
\text { Services }\end{array}$ & Security System \\
\hline \multirow[t]{2}{*}{ Amber } & \multirow{2}{*}{$\begin{array}{l}\text { Room can be used for confidential } \\
\text { meetings, but is not secure for classified } \\
\text { briefings in accordance with appropriate } \\
\text { security classification guide } \\
\text { Room cannot be secured for confidential } \\
\text { or classified briefings in accordance with } \\
\text { appropriate security classification guide }\end{array}$} & $\begin{array}{l}\text { Building } \\
\text { Services }\end{array}$ & Security System \\
\hline & & $\begin{array}{l}\text { Building } \\
\text { Services }\end{array}$ & Security System \\
\hline ISR-I Component & ISR-I Sub Component & ISR-I Priority & \\
\hline Conference Room & Computer/LAN System & Medium & \\
\hline ISR-I Rating & ISR-I Criteria & $\begin{array}{l}\text { BUILDER } \\
\text { Category }\end{array}$ & BUILDER Sub Issue \\
\hline Green & $\begin{array}{l}\text { Enough LAN outlets are available to } \\
\text { support current mission requirements }\end{array}$ & $\begin{array}{l}\text { Building } \\
\text { Services }\end{array}$ & Building IT System \\
\hline Amber & \multirow[t]{2}{*}{ Not enough LAN outlets are available } & $\begin{array}{l}\text { Building } \\
\text { Services }\end{array}$ & Building IT System \\
\hline Red & & $\begin{array}{l}\text { Building } \\
\text { Services }\end{array}$ & Building IT System \\
\hline ISR-I Component & ISR-I Sub Component & ISR-I Priority & \\
\hline Supply Storage & Space Layout & High & \\
\hline ISR-I Rating & ISR-I Criteria & $\begin{array}{l}\text { BUILDER } \\
\text { Category }\end{array}$ & BUILDER Sub Issue \\
\hline Green & Flexible layout enhances mobility & $\begin{array}{l}\text { Size/Config } \\
\text { uration }\end{array}$ & $\begin{array}{l}\text { Building } \\
\text { Configuration }\end{array}$ \\
\hline Green & Ample storage space to support mission & $\begin{array}{l}\text { Size/Config } \\
\text { uration }\end{array}$ & $\begin{array}{l}\text { Building } \\
\text { Configuration }\end{array}$ \\
\hline Green & Organized shelving available & $\begin{array}{l}\text { Size/Config } \\
\text { uration }\end{array}$ & $\begin{array}{l}\text { Building } \\
\text { Configuration }\end{array}$ \\
\hline Amber & Layout limits mobility throughout area & $\begin{array}{l}\text { Size/Config } \\
\text { uration }\end{array}$ & $\begin{array}{l}\text { Building } \\
\text { Configuration }\end{array}$ \\
\hline \multirow[t]{2}{*}{ Amber } & \multirow{2}{*}{$\begin{array}{l}\text { Limited storage space to support mission } \\
\text { Shelving exists, but is not enough to } \\
\text { support mission }\end{array}$} & $\begin{array}{l}\text { Size/Config } \\
\text { uration }\end{array}$ & $\begin{array}{l}\text { Building } \\
\text { Configuration }\end{array}$ \\
\hline & & $\begin{array}{l}\text { Size/Config } \\
\text { uration }\end{array}$ & $\begin{array}{l}\text { Building } \\
\text { Configuration }\end{array}$ \\
\hline \multirow[t]{3}{*}{ Red } & \multirow{3}{*}{$\begin{array}{l}\text { Space does not meet mission needs } \\
\text { No shelving present; items on the floor } \\
\text { block access to other storage areas }\end{array}$} & $\begin{array}{l}\text { Size/Config } \\
\text { uration }\end{array}$ & $\begin{array}{l}\text { Building } \\
\text { Configuration }\end{array}$ \\
\hline & & $\begin{array}{l}\text { Size/Config } \\
\text { uration }\end{array}$ & $\begin{array}{l}\text { Building } \\
\text { Configuration }\end{array}$ \\
\hline & & $\begin{array}{l}\text { Size/Config } \\
\text { uration }\end{array}$ & $\begin{array}{l}\text { Building } \\
\text { Configuration }\end{array}$ \\
\hline ISR-I Component & ISR-I Sub Component & ISR-I Priority & \\
\hline \multicolumn{4}{|l|}{ Forensic } \\
\hline ISR-I Rating & ISR-I Criteria & $\begin{array}{l}\text { BUILDER } \\
\text { Category }\end{array}$ & BUILDER Sub Issue \\
\hline Green & Flexible work space meets mission needs & $\begin{array}{l}\text { Size/Config } \\
\text { uration }\end{array}$ & $\begin{array}{l}\text { Building } \\
\text { Configuration }\end{array}$ \\
\hline
\end{tabular}




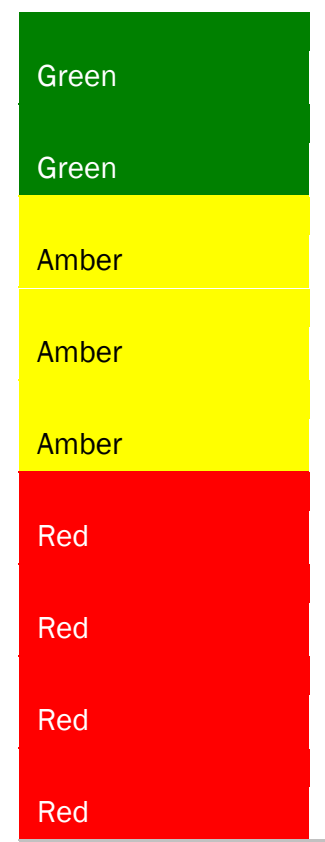

ISR-I Component

Forensic

Laboratories

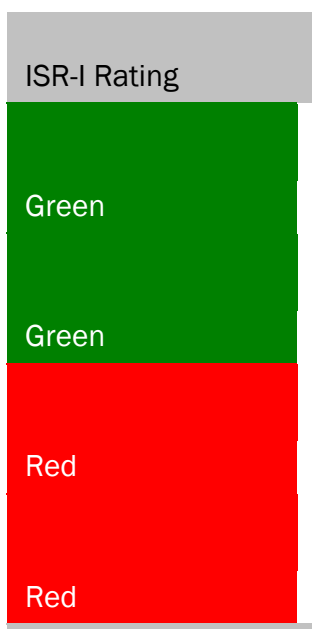

ISR-I Component
Corrosion resistant stainless steel single and double sinks available

Has hands free eye wash/shower station

Space limitations

Only single stainless steel sinks available

Manually operated eye wash/shower station

Poor inadequate layout of work space

Laboratory sinks are not stainless steel

No eye wash/shower station in immediate area

Cannot be verified when station last tested or that it works

\section{ISR-I Sub Component}

Fume Hoods

ISR-I Criteria

Hoods for hazardous and flammable

reagents have audible and visual alarms

Have automatic hood closure devices

Hoods for hazardous and flammable reagents, no audible and visual alarms

No automatic hood closure device ISR-I Sub Component

\begin{tabular}{|l|l|}
$\begin{array}{l}\text { Size/Config } \\
\text { uration }\end{array}$ & $\begin{array}{l}\text { Building } \\
\text { Configuration }\end{array}$ \\
\hline $\begin{array}{l}\text { Size/Config } \\
\text { uration }\end{array}$ & $\begin{array}{l}\text { Building } \\
\text { Configuration }\end{array}$ \\
\hline $\begin{array}{l}\text { Size/Config } \\
\text { uration }\end{array}$ & $\begin{array}{l}\text { Building } \\
\text { Configuration }\end{array}$ \\
\hline $\begin{array}{l}\text { Size/Config } \\
\text { uration }\end{array}$ & $\begin{array}{l}\text { Building } \\
\text { Configuration }\end{array}$ \\
\hline $\begin{array}{l}\text { Size/Config } \\
\text { uration }\end{array}$ & $\begin{array}{l}\text { Building } \\
\text { Configuration }\end{array}$ \\
\hline $\begin{array}{l}\text { Size/Config } \\
\text { uration }\end{array}$ & $\begin{array}{l}\text { Building } \\
\text { Configuration }\end{array}$ \\
\hline $\begin{array}{l}\text { Size/Config } \\
\text { uration }\end{array}$ & $\begin{array}{l}\text { Building } \\
\text { Configuration }\end{array}$ \\
\hline $\begin{array}{l}\text { Size/Config } \\
\text { uration }\end{array}$ & $\begin{array}{l}\text { Building } \\
\text { Configuration }\end{array}$ \\
\hline $\begin{array}{l}\text { Size/Config } \\
\text { uration }\end{array}$ & $\begin{array}{l}\text { Building } \\
\text { Configuration } \\
\text { ISR-I Priority }\end{array}$ \\
\hline
\end{tabular}

High

\begin{tabular}{|c|c|}
\hline $\begin{array}{l}\text { BUILDER } \\
\text { Category }\end{array}$ & BUILDER Sub Issue \\
\hline $\begin{array}{l}\text { Missing/Im- } \\
\text { proper } \\
\text { Comps }\end{array}$ & $\begin{array}{l}\text { Missing } \\
\text { Components? }\end{array}$ \\
\hline $\begin{array}{l}\text { Missing/Im- } \\
\text { proper } \\
\text { Comps }\end{array}$ & $\begin{array}{l}\text { Missing } \\
\text { Components? }\end{array}$ \\
\hline $\begin{array}{l}\text { Missing/Im- } \\
\text { proper } \\
\text { Comps }\end{array}$ & $\begin{array}{l}\text { Missing } \\
\text { Components? }\end{array}$ \\
\hline $\begin{array}{l}\text { Missing/Im- } \\
\text { proper } \\
\text { Comps }\end{array}$ & $\begin{array}{l}\text { Missing } \\
\text { Components? }\end{array}$ \\
\hline ISR-I Priority & \\
\hline High & \\
\hline $\begin{array}{l}\text { BUILDER } \\
\text { Category }\end{array}$ & BUILDER Sub Issue \\
\hline Comfort & $\begin{array}{l}\text { Ventilation } \\
\text { Capacity }\end{array}$ \\
\hline Comfort & $\begin{array}{l}\text { Ventilation } \\
\text { Capacity }\end{array}$ \\
\hline
\end{tabular}




\begin{tabular}{|c|c|c|c|}
\hline Red & $\begin{array}{l}\text { Positive or negative pressurization in the } \\
\text { labs is erratic and often forces suspension } \\
\text { of operations. Major repairs to the HVAC } \\
\text { system in the laboratories are required }\end{array}$ & Comfort & $\begin{array}{l}\text { Ventilation } \\
\text { Capacity }\end{array}$ \\
\hline ISR-I Component & ISR-I Sub Component & ISR-I Priority & \\
\hline $\begin{array}{l}\text { Forensic } \\
\text { Laboratories }\end{array}$ & Lighting and Electrical Outlets & High & \\
\hline ISR-I Rating & ISR-I Criteria & $\begin{array}{l}\text { BUILDER } \\
\text { Category }\end{array}$ & BUILDER Sub Issue \\
\hline Green & $\begin{array}{l}\text { Emergency egress and exit lights work, } \\
\text { and powered by emergency power or } \\
\text { battery backup }\end{array}$ & $\begin{array}{l}\text { Missing/Im- } \\
\text { proper } \\
\text { Comps }\end{array}$ & $\begin{array}{l}\text { Missing } \\
\text { Components? }\end{array}$ \\
\hline Green & $\begin{array}{l}\text { Grounded duplex, and GFI outlets at wet } \\
\text { locations }\end{array}$ & $\begin{array}{l}\text { Building } \\
\text { Services }\end{array}$ & Electrical Outlets \\
\hline Green & $\begin{array}{l}\text { All lighting and electrical outlets are on } \\
\text { emergency power circuits }\end{array}$ & $\begin{array}{l}\text { Building } \\
\text { Services }\end{array}$ & Electrical Outlets \\
\hline Amber & $\begin{array}{l}\text { Emergency egress and exit lights need } \\
\text { repair, or there is no emergency or battery } \\
\text { backup }\end{array}$ & $\begin{array}{l}\text { Missing/Im- } \\
\text { proper } \\
\text { Comps }\end{array}$ & $\begin{array}{l}\text { Missing } \\
\text { Components? }\end{array}$ \\
\hline Red & $\begin{array}{l}\text { Emergency egress and exit lights are not } \\
\text { in place }\end{array}$ & $\begin{array}{l}\text { Missing/Im- } \\
\text { proper } \\
\text { Comps }\end{array}$ & $\begin{array}{l}\text { Missing } \\
\text { Components? }\end{array}$ \\
\hline Red & $\begin{array}{l}\text { No grounded duplex of GFI oultets at wet } \\
\text { locations }\end{array}$ & $\begin{array}{l}\text { Building } \\
\text { Services }\end{array}$ & Electrical Outlets \\
\hline Red & $\begin{array}{l}\text { Lighting and electrical outlets are not tied } \\
\text { to emergency power circuits }\end{array}$ & $\begin{array}{l}\text { Building } \\
\text { Services }\end{array}$ & Electrical Outlets \\
\hline ISR-I Component & ISR-I Sub Component & ISR-I Priority & \\
\hline $\begin{array}{l}\text { Forensic } \\
\text { Laboratories }\end{array}$ & Medical Gases & High & \\
\hline ISR-I Rating & ISR-I Criteria & $\begin{array}{l}\text { BUILDER } \\
\text { Category }\end{array}$ & BUILDER Sub Issue \\
\hline Green & $\begin{array}{l}\text { Plumbed and concealed within the Lab } \\
\text { area walls }\end{array}$ & $\begin{array}{l}\text { Missing/Im- } \\
\text { proper } \\
\text { Comps }\end{array}$ & $\begin{array}{l}\text { Missing } \\
\text { Components? }\end{array}$ \\
\hline Amber & Gas lines are external to the lab walls & $\begin{array}{l}\text { Missing/Im- } \\
\text { proper } \\
\text { Comps }\end{array}$ & $\begin{array}{l}\text { Missing } \\
\text { Components? }\end{array}$ \\
\hline Red & Portable tanks are used for lab gases & $\begin{array}{l}\text { Missing/Im- } \\
\text { proper } \\
\text { Comps }\end{array}$ & $\begin{array}{l}\text { Missing } \\
\text { Components? }\end{array}$ \\
\hline ISR-I Component & ISR-I Sub Component & ISR-I Priority & \\
\hline $\begin{array}{l}\text { Forensic } \\
\text { Laboratories }\end{array}$ & Lab Refrigeration & High & \\
\hline ISR-I Rating & ISR-I Criteria & $\begin{array}{l}\text { BUILDER } \\
\text { Category }\end{array}$ & BUILDER Sub Issue \\
\hline Green & $\begin{array}{l}\text { Has refrigerated storage, all on emergency } \\
\text { power }\end{array}$ & $\begin{array}{l}\text { Missing/Im- } \\
\text { proper } \\
\text { Comps }\end{array}$ & $\begin{array}{l}\text { Missing } \\
\text { Components? }\end{array}$ \\
\hline
\end{tabular}




\begin{tabular}{|c|c|c|c|}
\hline Amber & $\begin{array}{l}\text { Has refrigerated storage, not all on } \\
\text { emergency power }\end{array}$ & $\begin{array}{l}\text { Missing/Im- } \\
\text { proper } \\
\text { Comps }\end{array}$ & $\begin{array}{l}\text { Missing } \\
\text { Components? }\end{array}$ \\
\hline Red & $\begin{array}{l}\text { No refrigeration, or none on emergency } \\
\text { power }\end{array}$ & $\begin{array}{l}\text { Missing/Im- } \\
\text { proper } \\
\text { Comps }\end{array}$ & $\begin{array}{l}\text { Missing } \\
\text { Components? }\end{array}$ \\
\hline ISR-I Component & ISR-I Sub Component & ISR-I Priority & \\
\hline $\begin{array}{l}\text { Forensic } \\
\text { Laboratories }\end{array}$ & $\begin{array}{l}\text { Joint Commission Accreditation Healthcare } \\
\text { Organizations (JACHO) and/or College of } \\
\text { American Pathologists (CAP) } \\
\text { Contingencies }\end{array}$ & High & \\
\hline ISR-I Rating & ISR-I Criteria & $\begin{array}{l}\text { BUILDER } \\
\text { Category }\end{array}$ & BUILDER Sub Issue \\
\hline Amber & \multicolumn{3}{|l|}{ Can be resolved with special procedures } \\
\hline Red & \multicolumn{3}{|c|}{ Contingencies identified; major repairs/renovation needed to resolve them } \\
\hline ISR-I Component & ISR-I Sub Component & ISR-I Priority & \\
\hline $\begin{array}{l}\text { Forensic } \\
\text { Laboratories }\end{array}$ & Computer / LAN System & Medium & \\
\hline ISR-I Rating & ISR-I Criteria & $\begin{array}{l}\text { BUILDER } \\
\text { Category }\end{array}$ & BUILDER Sub Issue \\
\hline Green & Enough LAN outlets to support mission & $\begin{array}{l}\text { Building } \\
\text { Services }\end{array}$ & Building IT System \\
\hline Amber & \multirow{2}{*}{$\begin{array}{l}\text { Not enough LAN outlets available } \\
\text { Additional LAN outlets are not available }\end{array}$} & $\begin{array}{l}\text { Building } \\
\text { Services }\end{array}$ & Building IT System \\
\hline Red & & $\begin{array}{l}\text { Building } \\
\text { Services }\end{array}$ & Building IT System \\
\hline ISR-I Component & ISR-I Sub Component & ISR-I Priority & \\
\hline $\begin{array}{l}\text { Forensic } \\
\text { Laboratories }\end{array}$ & Telephone System & Medium & \\
\hline ISR-I Rating & ISR-I Criteria & $\begin{array}{l}\text { BUILDER } \\
\text { Category }\end{array}$ & BUILDER Sub Issue \\
\hline Green & Enough telephone jacks for mission & $\begin{array}{l}\text { Building } \\
\text { Services }\end{array}$ & Telephone System \\
\hline Amber & \multirow[t]{2}{*}{ Not enough telephone jacks are available } & $\begin{array}{l}\text { Building } \\
\text { Services }\end{array}$ & Telephone System \\
\hline Red & & $\begin{array}{l}\text { Building } \\
\text { Services }\end{array}$ & Telephone System \\
\hline ISR-I Component & ISR-I Sub Component & ISR-I Priority & \\
\hline $\begin{array}{l}\text { Forensic } \\
\text { Laboratories }\end{array}$ & Signage & Low & \\
\hline ISR-I Rating & ISR-I Criteria & $\begin{array}{l}\text { BUILDER } \\
\text { Category }\end{array}$ & BUILDER Sub Issue \\
\hline Green & Coordinated for safety/way-finding & Access & $\begin{array}{l}\text { Directional Info and } \\
\text { Signage }\end{array}$ \\
\hline Green & $\begin{array}{l}\text { Doors to labs are marked with "Diamond } \\
\text { System" identifying hazardous agents and } \\
\text { flammables }\end{array}$ & Access & $\begin{array}{l}\text { Directional Info and } \\
\text { Signage }\end{array}$ \\
\hline
\end{tabular}




\begin{tabular}{l|l}
$\begin{array}{l}\text { Green } \\
\text { Amber }\end{array}$ & $\begin{array}{l}\text { Medical gases in the lab are marked at the } \\
\text { lab door and indentification tags are on } \\
\text { piping in the lab }\end{array}$ \\
Amber & Minimal and not clearly readable \\
Amber & $\begin{array}{l}\text { Medical gases in the lab are not clearly } \\
\text { marked on lab door or within lab }\end{array}$ \\
\hline Red & None, or signage is not current
\end{tabular}

\begin{tabular}{|l|l|} 
Access & $\begin{array}{l}\text { Directional Info and } \\
\text { Signage }\end{array}$ \\
\hline Access & $\begin{array}{l}\text { Directional Info and } \\
\text { Signage }\end{array}$ \\
\hline Access & $\begin{array}{l}\text { Directional Info and } \\
\text { Signage }\end{array}$ \\
\hline Access & $\begin{array}{l}\text { Directional Info and } \\
\text { Signage }\end{array}$ \\
\hline Access & $\begin{array}{l}\text { Directional Info and } \\
\text { Signage }\end{array}$ \\
\hline
\end{tabular}




\section{Appendix N: Army ISR-I Mapping to BUILDER Functionality Criteria, Warrior Transition Units}

\begin{tabular}{|c|c|c|c|}
\hline ISR-I Component & ISR-I Sub Component & ISR-I Priority & \\
\hline & Lighting & High & \\
\hline ISR-I Rating & ISR-I Criteria & BUILDER Category & $\begin{array}{l}\text { BUILDER Sub } \\
\text { Issue }\end{array}$ \\
\hline Green & $\begin{array}{l}\text { Has Lighting for Pedestrian, signage, } \\
\text { security, Landscaping }\end{array}$ & Access & $\begin{array}{l}\text { Building } \\
\text { Entry }\end{array}$ \\
\hline Amber & $\begin{array}{l}\text { No more than } 1 \text { of the } 4 \text { types of lighting in } \\
\text { Green column missing }\end{array}$ & Access & $\begin{array}{l}\text { Building } \\
\text { Entry }\end{array}$ \\
\hline Red & $\begin{array}{l}\text { Two or more of the } 4 \text { types of lighting in } \\
\text { Green column missing }\end{array}$ & Access & $\begin{array}{l}\text { Building } \\
\text { Entry }\end{array}$ \\
\hline Red & No Site and Grounds lighting exists & Access & $\begin{array}{l}\text { Building } \\
\text { Entry }\end{array}$ \\
\hline ISR-I Component & ISR-I Sub Component & ISR-I Priority & \\
\hline & Disabled Access & High & \\
\hline ISR-I Rating & ISR-I Criteria & BUILDER Category & $\begin{array}{l}\text { BUILDER Sub } \\
\text { Issue }\end{array}$ \\
\hline Green & ADAAG/UFAS accessible walkways & Accessibility & $\begin{array}{l}\text { ABA } \\
\text { compliance }\end{array}$ \\
\hline Green & $\begin{array}{l}\text { Curb ramps are present where accessible } \\
\text { routes cross a curb }\end{array}$ & Accessibility & $\begin{array}{l}\text { ABA } \\
\text { compliance }\end{array}$ \\
\hline Green & Ramps are minimum of 3 feet wide & Accessibility & $\begin{array}{l}\text { ABA } \\
\text { compliance }\end{array}$ \\
\hline Green & $\begin{array}{l}\text { Ramps of moderate slope, not exceeding a } \\
\text { rise of } 1: 12 \text { (one inch vertical per } 12 \\
\text { inches horizontal }\end{array}$ & Accessibility & $\begin{array}{l}\text { ABA } \\
\text { compliance }\end{array}$ \\
\hline Green & $\begin{array}{l}\text { Provides shortest accessible route to the } \\
\text { facility }\end{array}$ & Accessibility & $\begin{array}{l}\text { ABA } \\
\text { compliance }\end{array}$ \\
\hline Amber & ADAAG/UFAS accessible walkways & Accessibility & $\begin{array}{l}\text { ABA } \\
\text { compliance }\end{array}$ \\
\hline Amber & $\begin{array}{l}\text { Curb ramps are present where accessible } \\
\text { routes cross a curb }\end{array}$ & Accessibility & $\begin{array}{l}\text { ABA } \\
\text { compliance }\end{array}$ \\
\hline Amber & Ramps are minimum of 3 feet wide & Accessibility & $\begin{array}{l}\text { ABA } \\
\text { compliance }\end{array}$ \\
\hline Amber & $\begin{array}{l}\text { Ramps of moderate slope, not exceeding a } \\
\text { rise of } 1: 12 \text { (one inch vertical per } 12 \\
\text { inches horizontal }\end{array}$ & Accessibility & $\begin{array}{l}\text { ABA } \\
\text { compliance }\end{array}$ \\
\hline Red & $\begin{array}{l}\text { Does not meet AMBER column minimum } \\
\text { conditions }\end{array}$ & Accessibility & $\begin{array}{l}\text { ABA } \\
\text { compliance }\end{array}$ \\
\hline ISR-I Component & ISR-I Sub Component & ISR-I Priority & \\
\hline
\end{tabular}




\begin{tabular}{|c|c|c|c|}
\hline $\begin{array}{l}\text { Sites and } \\
\text { Grounds }\end{array}$ & Turf and Pavement Drainage & \multicolumn{2}{|l|}{ Medium } \\
\hline ISR-I Rating & ISR-I Criteria & BUILDER Category & $\begin{array}{l}\text { BUILDER Sub } \\
\text { Issue }\end{array}$ \\
\hline Green & Surfaces are sloped to drain & \multicolumn{2}{|l|}{ Drainage } \\
\hline Amber & Surfaces are not sloped to drain & \multicolumn{2}{|l|}{ Drainage } \\
\hline Red & Surfaces are not draining & \multicolumn{2}{|l|}{ Drainage } \\
\hline ISR-I Component & ISR-I Sub Component & \multicolumn{2}{|l|}{ ISR-I Priority } \\
\hline $\begin{array}{l}\text { Sites and } \\
\text { Grounds }\end{array}$ & Paved Sidewalks & \multicolumn{2}{|l|}{ Medium } \\
\hline ISR-I Rating & ISR-I Criteria & BUILDER Category & $\begin{array}{l}\text { BUILDER Sub } \\
\text { Issue }\end{array}$ \\
\hline Green & Installed from parking lot to facility & Access & $\begin{array}{l}\text { Building } \\
\text { Entry }\end{array}$ \\
\hline Green & Installed from adjacent streets to facility & Access & $\begin{array}{l}\text { Building } \\
\text { Entry }\end{array}$ \\
\hline Green & At least 4 feet wide & Access & $\begin{array}{l}\text { Building } \\
\text { Entry }\end{array}$ \\
\hline Amber & Not installed from parking to facility & Access & $\begin{array}{l}\text { Building } \\
\text { Entry }\end{array}$ \\
\hline Amber & Not installed from streets to facility & \multirow[t]{2}{*}{ Access } & $\begin{array}{l}\text { Building } \\
\text { Entry }\end{array}$ \\
\hline Amber & \multirow[t]{2}{*}{ Less than 4 feet wide } & & $\begin{array}{l}\text { Building } \\
\text { Entry }\end{array}$ \\
\hline Red & & Access & $\begin{array}{l}\text { Building } \\
\text { Entry }\end{array}$ \\
\hline ISR-I Component & ISR-I Sub Component & ISR-I Priority & \\
\hline $\begin{array}{l}\text { Sites and } \\
\text { Grounds }\end{array}$ & Landscaping & \multicolumn{2}{|l|}{ Low } \\
\hline ISR-I Rating & ISR-I Criteria & BUILDER Category & $\begin{array}{l}\text { BUILDER Sub } \\
\text { Issue }\end{array}$ \\
\hline Green & $\begin{array}{l}\text { Displays a mixture of colorful plants and } \\
\text { greenery appropriate to the area }\end{array}$ & Aesthetics & $\begin{array}{l}\text { Exterior } \\
\text { Aesthetics }\end{array}$ \\
\hline Amber & \multirow[t]{2}{*}{ Displays few color planting or greenery } & \multirow[t]{2}{*}{ Aesthetics } & $\begin{array}{l}\text { Exterior } \\
\text { Aesthetics }\end{array}$ \\
\hline Red & & & $\begin{array}{l}\text { Exterior } \\
\text { Aesthetics }\end{array}$ \\
\hline ISR-I Component & ISR-I Sub Component & ISR-I Priority & \\
\hline $\begin{array}{l}\text { Sites and } \\
\text { Grounds }\end{array}$ & Dumpster & Low & \\
\hline ISR-I Rating & ISR-I Criteria & BUILDER Category & $\begin{array}{l}\text { BUILDER Sub } \\
\text { Issue }\end{array}$ \\
\hline \multirow[t]{2}{*}{ Green } & \multirow[t]{2}{*}{$\begin{array}{l}\text { Screened by walls or landscaping high } \\
\text { enough ( } 6-8 \text { feet) to restrict view from; } \\
\text { building occupants, entrances, streets, } \\
\text { parking lots }\end{array}$} & \multirow[t]{2}{*}{ Aesthetics } & $\begin{array}{l}\text { Exterior } \\
\text { Aesthetics }\end{array}$ \\
\hline & & & $\begin{array}{l}\text { ATFP } \\
\text { Requirement } \\
\mathrm{s}\end{array}$ \\
\hline
\end{tabular}




\begin{tabular}{|c|c|c|c|}
\hline Green & $\begin{array}{l}82 \text { feet or more away from billeting or } \\
\text { housing }\end{array}$ & ATFP & $\begin{array}{l}\text { ATFP } \\
\text { Requirement } \\
\mathrm{s}\end{array}$ \\
\hline Amber & $\begin{array}{l}\text { Not screened by walls or landscaping } \\
\text { sufficiently high to obscure view }\end{array}$ & Aesthetics & $\begin{array}{l}\text { Exterior } \\
\text { Aesthetics }\end{array}$ \\
\hline \multirow[t]{2}{*}{ Amber } & $\begin{array}{l}\text { More than } 20 \text { feet away, but less than } 33 \\
\text { feet away from other occupied facilities }\end{array}$ & ATFP & $\begin{array}{l}\text { ATFP } \\
\text { Requirement } \\
\mathrm{s}\end{array}$ \\
\hline & $\begin{array}{l}\text { More than } 50 \text { feet away, but less than } 82 \\
\text { feet away, from billeting or housing }\end{array}$ & ATFP & $\begin{array}{l}\text { ATFP } \\
\text { Requirement } \\
\mathrm{s}\end{array}$ \\
\hline Red & Not enclosed or screened from view & Aesthetics & $\begin{array}{l}\text { Exterior } \\
\text { Aesthetics }\end{array}$ \\
\hline \multirow[t]{2}{*}{ Red } & \multirow[t]{2}{*}{$\begin{array}{l}\text { Less than } 20 \text { feet away from other } \\
\text { occupied facilities }\end{array}$} & \multirow[t]{2}{*}{ ATFP } & $\begin{array}{l}\text { ATFP } \\
\text { Requirement } \\
\mathrm{s}\end{array}$ \\
\hline & & & $\begin{array}{l}\text { ATFP } \\
\text { Requirement } \\
\mathrm{s}\end{array}$ \\
\hline ISR-I Component & ISR-I Sub Component & ISR-I Priority & \\
\hline \multicolumn{4}{|l|}{$\begin{array}{l}\text { Sites and } \\
\text { Grounds }\end{array}$} \\
\hline ISR-I Rating & ISR-I Criteria & BUILDER Category & $\begin{array}{l}\text { BUILDER Sub } \\
\text { Issue }\end{array}$ \\
\hline \multirow[t]{2}{*}{ Green } & \multirow{2}{*}{$\begin{array}{l}\text { All utility lines are underground } \\
\text { Utility equipment is screened by } \\
\text { landscaping or fencing }\end{array}$} & Aesthetics & $\begin{array}{l}\text { Exterior } \\
\text { Aesthetics }\end{array}$ \\
\hline & & Aesthetics & $\begin{array}{l}\text { Exterior } \\
\text { Aesthetics }\end{array}$ \\
\hline \multirow[t]{2}{*}{ Amber } & \multirow{3}{*}{$\begin{array}{l}\text { Utility lines are not underground } \\
\text { Utility equipment is screened by } \\
\text { landscaping or fencing } \\
\text { Utility lines and equipment are exposed } \\
\text { and disorderly }\end{array}$} & Aesthetics & $\begin{array}{l}\text { Exterior } \\
\text { Aesthetics }\end{array}$ \\
\hline & & \multirow[t]{2}{*}{ Aesthetics } & $\begin{array}{l}\text { Exterior } \\
\text { Aesthetics }\end{array}$ \\
\hline Red & & & $\begin{array}{l}\text { Exterior } \\
\text { Aesthetics }\end{array}$ \\
\hline ISR-I Component & ISR-I Sub Component & ISR-I Priority & \\
\hline Parking & Parking Availability & High & \\
\hline ISR-I Rating & ISR-I Criteria & BUILDER Category & $\begin{array}{l}\text { BUILDER Sub } \\
\text { Issue }\end{array}$ \\
\hline \multirow[t]{2}{*}{ Green } & $\begin{array}{l}\text { Parking spaces are provided for } 70 \% \text { of } \\
\text { rooms with a minimum of } 20 \% \text { complying } \\
\text { with handicap accessible parking } \\
\text { (ADAAG/UFAS, section } 502 \text { ) }\end{array}$ & \multirow[t]{2}{*}{ Accessibility } & $\begin{array}{l}\text { ABA } \\
\text { compliance }\end{array}$ \\
\hline & $\begin{array}{l}\text { Curb ramps are present wherever } \\
\text { accessible routes cross a curb }\end{array}$ & & $\begin{array}{l}\text { ABA } \\
\text { compliance }\end{array}$ \\
\hline \multirow[t]{2}{*}{ Green } & \multirow{2}{*}{$\begin{array}{l}\text { Accessible parking ramps are a minimum } \\
\text { of } 3 \text { feet wide and have a maximum rise of } \\
\text { 1:12 (one inch vertical per } 12 \text { inches } \\
\text { horizontal) } \\
\text { Provides for shortest accessible route to } \\
\text { the facility accessible entrance }\end{array}$} & \multirow[t]{2}{*}{ Accessibility } & $\begin{array}{l}\text { ABA } \\
\text { compliance }\end{array}$ \\
\hline & & & $\begin{array}{l}\text { ABA } \\
\text { compliance }\end{array}$ \\
\hline
\end{tabular}




\begin{tabular}{|c|c|c|c|}
\hline \multirow{3}{*}{$\begin{array}{l}\text { Amber } \\
\text { Amber }\end{array}$} & $\begin{array}{l}\text { Parking spaces are provided for } 70 \% \text { of } \\
\text { rooms, with a minimum of } 20 \% \text { complying } \\
\text { with handicap accessible parking } \\
\text { (ADAAG/UFAS, section 502) }\end{array}$ & Accessibility & \multirow{2}{*}{$\begin{array}{l}\text { ABA } \\
\text { compliance } \\
\text { ABA } \\
\text { compliance }\end{array}$} \\
\hline & $\begin{array}{l}\text { Curb ramps are present wherever } \\
\text { accessible routes cross a curb }\end{array}$ & Accessibility & \\
\hline & \multirow{2}{*}{$\begin{array}{l}\text { Accessible parking ramps are a minimum } \\
\text { of } 3 \text { feet wide and have a maximum rise of } \\
1: 12 \text { (one inch vertical per } 12 \text { inches } \\
\text { horizontal } \\
\text { Does not meet AMBER column minimum } \\
\text { requirements }\end{array}$} & \multirow[t]{2}{*}{ Accessibility } & $\begin{array}{l}\text { ABA } \\
\text { compliance }\end{array}$ \\
\hline Red & & & $\begin{array}{l}\text { ABA } \\
\text { compliance }\end{array}$ \\
\hline ISR-I Component & ISR-I Sub Component & ISR-I Priority & \\
\hline Parking & Parking Area Standoff & High & \\
\hline ISR-I Rating & ISR-I Criteria & BUILDER Category & $\begin{array}{l}\text { BUILDER Sub } \\
\text { Issue }\end{array}$ \\
\hline \multirow[t]{2}{*}{ Green } & \multirow{2}{*}{$\begin{array}{l}\text { Parking spaces are located } 82 \text { feet or more } \\
\text { away from occupied facilities } \\
\text { Within controlled perimeters, parking } \\
\text { spaces are located } 33 \text { feet or more away } \\
\text { from occupied facilities }\end{array}$} & ATFP & $\begin{array}{l}\text { ATFP } \\
\text { Requirement } \\
\mathrm{s}\end{array}$ \\
\hline & & ATFP & $\begin{array}{l}\text { ATFP } \\
\text { Requirement } \\
\mathrm{s}\end{array}$ \\
\hline \multirow[t]{2}{*}{ Red } & \multirow{2}{*}{$\begin{array}{l}\text { Parking spaces are located less than } 82 \\
\text { feet away from occupied facilities } \\
\text { Within controlled perimeters, parking } \\
\text { spaces are located less than } 33 \text { feet from } \\
\text { occupied facilities }\end{array}$} & \multirow[t]{2}{*}{ ATFP } & $\begin{array}{l}\text { ATFP } \\
\text { Requirement } \\
\mathrm{s}\end{array}$ \\
\hline & & & $\begin{array}{l}\text { ATFP } \\
\text { Requirement } \\
\mathrm{s}\end{array}$ \\
\hline ISR-I Component & ISR-I Sub Component & ISR-I Priority & \\
\hline Parking & Parking Area Lighting & High & \\
\hline ISR-I Rating & ISR-I Criteria & BUILDER Category & $\begin{array}{l}\text { BUILDER Sub } \\
\text { Issue }\end{array}$ \\
\hline \multirow[t]{2}{*}{ Green } & \multirow{2}{*}{$\begin{array}{l}\text { Provides direct or area lighting for: Traffic } \\
\text { Flow, Pedrestian Movement, Signage) } \\
\text { Not more than } 1 \text { of the } 3 \text { types of lighting in } \\
\text { the GREEN column is missing }\end{array}$} & \multirow[t]{2}{*}{ Access } & $\begin{array}{l}\text { Directional } \\
\text { Info and } \\
\text { Signage }\end{array}$ \\
\hline & & & $\begin{array}{l}\text { Directional } \\
\text { Info and } \\
\text { Signage }\end{array}$ \\
\hline ISR-I Component & ISR-I Sub Component & ISR-I Priority & \\
\hline Parking & Parking Pavement Drainage & Medium & \\
\hline ISR-I Rating & ISR-I Criteria & BUILDER Category & $\begin{array}{l}\text { BUILDER Sub } \\
\text { Issue }\end{array}$ \\
\hline Green & Sloped to drain & Drainage & \\
\hline Amber & Not well sloped to drain & Drainage & \\
\hline Red & Not draining & Drainage & \\
\hline ISR-I Component & ISR-I Sub Component & ISR-I Priority & \\
\hline Parking & Parking Spaces & Medium & \\
\hline ISR-I Rating & ISR-I Criteria & BUILDER Category & $\begin{array}{l}\text { BUILDER Sub } \\
\text { Issue }\end{array}$ \\
\hline
\end{tabular}




\begin{tabular}{|c|c|c|c|}
\hline \multirow{2}{*}{$\begin{array}{l}\text { Green } \\
\text { Green }\end{array}$} & \multirow{2}{*}{$\begin{array}{l}\text { Handicap accessible spaces are sized a } \\
\text { minimum } 96 \text { inches wide by } 16 \text { feet long } \\
\text { for standard parking } \\
\text { Handicap accessible van spaces are sized } \\
\text { a minimum } 132 \text { inches wide by } 16 \text { feet } \\
\text { long and have a } 60 \text { inch wide access isle }\end{array}$} & \multirow[t]{2}{*}{ Accessibility } & $\begin{array}{l}\text { ABA } \\
\text { compliance }\end{array}$ \\
\hline & & & $\begin{array}{l}\text { ABA } \\
\text { compliance }\end{array}$ \\
\hline \multirow[t]{2}{*}{ Amber } & $\begin{array}{l}\text { Handicap accessible spaces are sized a } \\
\text { minimum } 96 \text { inches wide by } 16 \text { feet long } \\
\text { for standard parking }\end{array}$ & \multirow[t]{2}{*}{ Accessibility } & $\begin{array}{l}\text { ABA } \\
\text { compliance }\end{array}$ \\
\hline & $\begin{array}{l}\text { Handicap accessible van spaces are sized } \\
\text { a minimum } 132 \text { inches wide by } 16 \text { feet } \\
\text { long and have a } 60 \text { inch wide access isle }\end{array}$ & & $\begin{array}{l}\text { ABA } \\
\text { compliance }\end{array}$ \\
\hline ISR-I Component & ISR-I Sub Component & ISR-I Priority & \\
\hline Parking & Parking Signage & Medium & \\
\hline ISR-I Rating & ISR-I Criteria & BUILDER Category & $\begin{array}{l}\text { BUILDER Sub } \\
\text { Issue }\end{array}$ \\
\hline Green & ADAAG/UFAS compliant & Accessibility & $\begin{array}{l}\text { ABA } \\
\text { compliance }\end{array}$ \\
\hline \multirow[t]{2}{*}{ Green } & $\begin{array}{l}\text { Lot(s) and rows have identity signs and } \\
\text { traffic control signs, all clearly legible }\end{array}$ & Access & $\begin{array}{l}\text { Directional } \\
\text { Info and } \\
\text { Signage }\end{array}$ \\
\hline & $\begin{array}{l}\text { Signs provide directions from parking areas } \\
\text { along walkways to the facility }\end{array}$ & Access & $\begin{array}{l}\text { Directional } \\
\text { Info and } \\
\text { Signage }\end{array}$ \\
\hline Amber & ADAAG/UFAS compliant & Accessibility & $\begin{array}{l}\text { ABA } \\
\text { compliance }\end{array}$ \\
\hline \multirow[t]{2}{*}{ Amber } & \multirow{3}{*}{$\begin{array}{l}\text { Limited traffic control and lot/row identity } \\
\text { signs; signs hard to read from vehicles } \\
\text { Signs providing directions from parking } \\
\text { areas along walkways to the facility are not } \\
\text { current or are illegible } \\
\text { Does not meet AMBER column minimum } \\
\text { conditions }\end{array}$} & Access & $\begin{array}{l}\text { Directional } \\
\text { Info and } \\
\text { Signage }\end{array}$ \\
\hline & & \multirow[t]{2}{*}{ Access } & $\begin{array}{l}\text { Directional } \\
\text { Info and } \\
\text { Signage }\end{array}$ \\
\hline Red & & & $\begin{array}{l}\text { ABA } \\
\text { compliance }\end{array}$ \\
\hline ISR-I Component & ISR-I Sub Component & ISR-I Priority & \\
\hline Parking & Parking Landscaping & Low & \\
\hline ISR-I Rating & ISR-I Criteria & BUILDER Category & $\begin{array}{l}\text { BUILDER Sub } \\
\text { Issue }\end{array}$ \\
\hline Green & $\begin{array}{l}\text { Displays a mixture of colorful plants and } \\
\text { greenery appropriate to the area }\end{array}$ & Aesthetics & $\begin{array}{l}\text { Exterior } \\
\text { Aesthetics }\end{array}$ \\
\hline Amber & $\begin{array}{l}\text { Displays few plantings of color and } \\
\text { greenery }\end{array}$ & Aesthetics & $\begin{array}{l}\text { Exterior } \\
\text { Aesthetics }\end{array}$ \\
\hline Red & No plantings & Aesthetics & $\begin{array}{l}\text { Exterior } \\
\text { Aesthetics }\end{array}$ \\
\hline ISR-I Component & ISR-I Sub Component & ISR-I Priority & \\
\hline $\begin{array}{l}\text { Building Exterior - } \\
\text { General }\end{array}$ & Outside Drainage & High & \\
\hline ISR-I Rating & ISR-I Criteria & BUILDER Category & $\begin{array}{l}\text { BUILDER Sub } \\
\text { Issue }\end{array}$ \\
\hline
\end{tabular}




\begin{tabular}{|c|c|c|c|}
\hline Green & Outflow drains away from the building & \multicolumn{2}{|l|}{ Drainage } \\
\hline Amber & $\begin{array}{l}\text { Outflow ponds at the building base around } \\
\text { splash blocks }\end{array}$ & \multicolumn{2}{|l|}{ Drainage } \\
\hline Red & $\begin{array}{l}\text { Outflow ponds at building base; no splash } \\
\text { blocks }\end{array}$ & \multicolumn{2}{|l|}{ Drainage } \\
\hline ISR-I Component & ISR-I Sub Component & \multicolumn{2}{|l|}{ ISR-I Priority } \\
\hline $\begin{array}{l}\text { Building Exterior - } \\
\text { General }\end{array}$ & Exterior Lighting & \multicolumn{2}{|l|}{ High } \\
\hline ISR-I Rating & ISR-I Criteria & BUILDER Category & $\begin{array}{l}\text { BUILDER Sub } \\
\text { Issue }\end{array}$ \\
\hline \multirow[t]{2}{*}{ Green } & $\begin{array}{l}\text { Provides direct or area lighting for: } \\
\text { (Security, Pedrestrian Movement, Safety } \\
\text { and Exit Routes, Generate Exterior) }\end{array}$ & \multirow[t]{2}{*}{ Access } & $\begin{array}{l}\text { Directional } \\
\text { Info and } \\
\text { Signage }\end{array}$ \\
\hline & $\begin{array}{l}\text { Not more than } 1 \text { of the } 4 \text { types of lighting in } \\
\text { the GREEN column is missing }\end{array}$ & & $\begin{array}{l}\text { Directional } \\
\text { Info and } \\
\text { Signage }\end{array}$ \\
\hline ISR-I Component & ISR-I Sub Component & \multicolumn{2}{|l|}{ ISR-I Priority } \\
\hline $\begin{array}{l}\text { Building Exterior - } \\
\text { General }\end{array}$ & Building Exterior Signage & \multicolumn{2}{|l|}{ Medium } \\
\hline ISR-I Rating & ISR-I Criteria & BUILDER Category & $\begin{array}{l}\text { BUILDER Sub } \\
\text { Issue }\end{array}$ \\
\hline \multirow[t]{2}{*}{ Green } & \multirow[t]{2}{*}{ ADAAG/UFAS compliant } & \multirow[t]{2}{*}{ Accessibility } & $\begin{array}{l}\text { ABA } \\
\text { compliance }\end{array}$ \\
\hline & & & $\begin{array}{l}\text { Directional } \\
\text { Info and } \\
\text { Signage }\end{array}$ \\
\hline \multirow[t]{2}{*}{ Green } & \multirow[t]{2}{*}{$\begin{array}{l}\text { Includes directions to parking, entrances, } \\
\text { and facilities }\end{array}$} & \multirow[t]{2}{*}{ Access } & $\begin{array}{l}\text { Directional } \\
\text { Info and } \\
\text { Signage }\end{array}$ \\
\hline & & & $\begin{array}{l}\text { Directional } \\
\text { Info and } \\
\text { Signage }\end{array}$ \\
\hline Amber & ADAAG/UFAS compliant & Accessibility & $\begin{array}{l}\text { ABA } \\
\text { compliance }\end{array}$ \\
\hline Amber & Not well coordinated, but readable & Access & $\begin{array}{l}\text { Directional } \\
\text { Info and } \\
\text { Signage }\end{array}$ \\
\hline Amber & $\begin{array}{l}\text { Missing directories to parking, entrances, } \\
\text { or facilities }\end{array}$ & \multirow[t]{2}{*}{ Access } & $\begin{array}{l}\text { Directional } \\
\text { Info and } \\
\text { Signage }\end{array}$ \\
\hline Red & $\begin{array}{l}\text { Does not meet AMBER column minimum } \\
\text { conditions }\end{array}$ & & $\begin{array}{l}\text { Directional } \\
\text { Info and } \\
\text { Signage }\end{array}$ \\
\hline ISR-I Component & ISR-I Sub Component & ISR-I Priority & \\
\hline $\begin{array}{l}\text { Building Exterior - } \\
\text { General }\end{array}$ & Mechanical Equipment & Low & \\
\hline ISR-I Rating & ISR-I Criteria & BUILDER Category & $\begin{array}{l}\text { BUILDER Sub } \\
\text { Issue }\end{array}$ \\
\hline Green & $\begin{array}{l}\text { Screened and painted to match building } \\
\text { design }\end{array}$ & Aesthetics & $\begin{array}{l}\text { Exterior } \\
\text { Aesthetics }\end{array}$ \\
\hline
\end{tabular}




\begin{tabular}{|c|c|c|c|}
\hline \multirow{2}{*}{$\begin{array}{l}\text { Amber } \\
\text { Red }\end{array}$} & \multirow{2}{*}{$\begin{array}{l}\text { Unscreened, but painted to match building } \\
\text { color } \\
\text { Unscreened and not painted to match } \\
\text { building color }\end{array}$} & \multirow{2}{*}{$\begin{array}{l}\text { Aesthetics } \\
\text { Aesthetics }\end{array}$} & $\begin{array}{l}\text { Exterior } \\
\text { Aesthetics }\end{array}$ \\
\hline & & & $\begin{array}{l}\text { Exterior } \\
\text { Aesthetics }\end{array}$ \\
\hline ISR-I Component & ISR-I Sub Component & ISR-I Priority & \\
\hline $\begin{array}{l}\text { Building Exterior - } \\
\text { Roof }\end{array}$ & Roof & High & \\
\hline ISR-I Rating & ISR-I Criteria & BUILDER Category & $\begin{array}{l}\text { BUILDER Sub } \\
\text { Issue }\end{array}$ \\
\hline Green & Walkways prevent foot traffic damage & $\begin{array}{l}\text { Missing or } \\
\text { Improper } \\
\text { Components }\end{array}$ & $\begin{array}{l}\text { Missing } \\
\text { Components } \\
?\end{array}$ \\
\hline Amber & $\begin{array}{l}\text { Walkways are present, but there is } \\
\text { noticeable damage to roof material }\end{array}$ & $\begin{array}{l}\text { Missing or } \\
\text { Improper } \\
\text { Components }\end{array}$ & $\begin{array}{l}\text { Missing } \\
\text { Components } \\
?\end{array}$ \\
\hline Red & $\begin{array}{l}\text { No walkways; noticeable damage to roof } \\
\text { material }\end{array}$ & $\begin{array}{l}\text { Missing or } \\
\text { Improper } \\
\text { Components }\end{array}$ & $\begin{array}{l}\text { Missing } \\
\text { Components } \\
?\end{array}$ \\
\hline ISR-I Component & ISR-I Sub Component & ISR-I Priority & \\
\hline $\begin{array}{l}\text { Building Exterior - } \\
\text { Roof }\end{array}$ & Rooftop Mechanical Units & Medium & \\
\hline ISR-I Rating & ISR-I Criteria & BUILDER Category & $\begin{array}{l}\text { BUILDER Sub } \\
\text { Issue }\end{array}$ \\
\hline Green & $\begin{array}{l}\text { Screened from view of adjacent/taller } \\
\text { buildings. Penthouse or screens installed. }\end{array}$ & Aesthetics & $\begin{array}{l}\text { Exterior } \\
\text { Aesthetics }\end{array}$ \\
\hline Amber & $\begin{array}{l}\text { Screened from view of adjacent/taller } \\
\text { buildings. Penthouse or screens in } \\
\text { disrepair, but cannot see units. }\end{array}$ & Aesthetics & $\begin{array}{l}\text { Exterior } \\
\text { Aesthetics }\end{array}$ \\
\hline Red & $\begin{array}{l}\text { Not screened from view of adjacent/taller } \\
\text { buildings. Penthouse or screens do not } \\
\text { prevent view from adjacent/taller buildings. }\end{array}$ & Aesthetics & $\begin{array}{l}\text { Exterior } \\
\text { Aesthetics }\end{array}$ \\
\hline ISR-I Component & ISR-I Sub Component & ISR-I Priority & \\
\hline $\begin{array}{l}\text { Buildng Exterior - } \\
\text { Doors }\end{array}$ & Disabled Access & High & \\
\hline ISR-I Rating & ISR-I Criteria & BUILDER Category & $\begin{array}{l}\text { BUILDER Sub } \\
\text { Issue }\end{array}$ \\
\hline Green & Meets ADAAG/UFAS requirements & Accessibility & $\begin{array}{l}\text { ABA } \\
\text { compliance }\end{array}$ \\
\hline Red & $\begin{array}{l}\text { Does not meet GREEN column minimum } \\
\text { requirements }\end{array}$ & Accessibility & $\begin{array}{l}\text { ABA } \\
\text { compliance }\end{array}$ \\
\hline ISR-I Component & ISR-I Sub Component & ISR-I Priority & \\
\hline $\begin{array}{l}\text { Buildng Exterior - } \\
\text { Doors }\end{array}$ & Exterior Doors & High & \\
\hline ISR-I Rating & ISR-I Criteria & BUILDER Category & $\begin{array}{l}\text { BUILDER Sub } \\
\text { Issue }\end{array}$ \\
\hline Amber & Hinge pins can be removed from outside & ATFP & $\begin{array}{l}\text { ATFP } \\
\text { Requirement } \\
\mathrm{s}\end{array}$ \\
\hline
\end{tabular}




\begin{tabular}{|c|c|c|c|}
\hline Red & Hinge pins are easily removed from outside & ATFP & $\begin{array}{l}\text { ATFP } \\
\text { Requirement } \\
\mathrm{s}\end{array}$ \\
\hline ISR-I Component & ISR-I Sub Component & ISR-I Priority & \\
\hline Lobby & Lobby Area & High & \\
\hline ISR-I Rating & ISR-I Criteria & BUILDER Category & $\begin{array}{l}\text { BUILDER Sub } \\
\text { Issue }\end{array}$ \\
\hline Green & $\begin{array}{l}\text { ADAAG/UFAS compliant and meets mission } \\
\text { needs }\end{array}$ & Accessibility & $\begin{array}{l}\text { ABA } \\
\text { compliance }\end{array}$ \\
\hline Green & $\begin{array}{l}\text { ADAAG/UFAS accessible public restroom is } \\
\text { provided near building entrance or lobby } \\
\text { area }\end{array}$ & Accessibility & $\begin{array}{l}\text { ABA } \\
\text { compliance }\end{array}$ \\
\hline Green & $\begin{array}{l}\text { ADAAG/UFAS accessible water fountain is } \\
\text { provided near building entrance of lobby } \\
\text { area }\end{array}$ & Accessibility & $\begin{array}{l}\text { ABA } \\
\text { compliance }\end{array}$ \\
\hline Amber & $\begin{array}{l}\text { ADAAG/UFAS compliant and meets mission } \\
\text { needs }\end{array}$ & Accessibility & $\begin{array}{l}\text { ABA } \\
\text { compliance }\end{array}$ \\
\hline Amber & $\begin{array}{l}\text { ADAAG/UFAS accessible public restroom is } \\
\text { provided }\end{array}$ & Accessibility & $\begin{array}{l}\text { ABA } \\
\text { compliance }\end{array}$ \\
\hline Amber & $\begin{array}{l}\text { ADAAG/UFAS accessible water fountain is } \\
\text { provided }\end{array}$ & Accessibility & $\begin{array}{l}\text { ABA } \\
\text { compliance }\end{array}$ \\
\hline Red & $\begin{array}{l}\text { Does not meet AMBER column minimum } \\
\text { conditions }\end{array}$ & Accessibility & $\begin{array}{l}\text { ABA } \\
\text { compliance }\end{array}$ \\
\hline ISR-I Component & ISR-I Sub Component & ISR-I Priority & \\
\hline Lobby & Lighting and Outlets & High & \\
\hline ISR-I Rating & ISR-I Criteria & BUILDER Category & $\begin{array}{l}\text { BUILDER Sub } \\
\text { Issue }\end{array}$ \\
\hline Green & $\begin{array}{l}\text { At least one electrical duplex outlet (three } \\
\text { prong grounded) on all wall surfaces }\end{array}$ & Building Services & $\begin{array}{l}\text { Electrical } \\
\text { Grounding } \\
\text { System }\end{array}$ \\
\hline Amber & $\begin{array}{l}\text { One or more walls lack grounded duplex } \\
\text { outlets }\end{array}$ & Building Services & $\begin{array}{l}\text { Electrical } \\
\text { Grounding } \\
\text { System }\end{array}$ \\
\hline Red & No grounded duplex outlets in lobby, or & Building Services & $\begin{array}{l}\text { Electrical } \\
\text { Grounding } \\
\text { System }\end{array}$ \\
\hline ISR-I Component & ISR-I Sub Component & ISR-I Priority & \\
\hline Lobby & Interior Doors & Medium & \\
\hline ISR-I Rating & ISR-I Criteria & BUILDER Category & $\begin{array}{l}\text { BUILDER Sub } \\
\text { Issue }\end{array}$ \\
\hline Green & Have lever handles or push-plates & Accessibility & $\begin{array}{l}\text { ABA } \\
\text { compliance }\end{array}$ \\
\hline Green & $\begin{array}{l}\text { Allow access by the disabled to public or } \\
\text { work spaces in the facility }\end{array}$ & Accessibility & $\begin{array}{l}\text { ABA } \\
\text { compliance }\end{array}$ \\
\hline Green & $\begin{array}{l}\text { Interior doors that are also fire/exit doors, } \\
\text { and normally in an open position, are } \\
\text { equipped with automatic closure devices } \\
\text { and panic hardware }\end{array}$ & ATFP & $\begin{array}{l}\text { ATFP } \\
\text { Requirement } \\
\mathrm{s}\end{array}$ \\
\hline
\end{tabular}




\begin{tabular}{|c|c|c|c|}
\hline \multirow[t]{2}{*}{ Green } & \multicolumn{2}{|l|}{$\begin{array}{l}\text { Interior doors that exit to the exterior are } \\
\text { metal or solid core wood and open easily }\end{array}$} & $\begin{array}{l}\text { ATFP } \\
\text { Requirement } \\
\mathrm{s}\end{array}$ \\
\hline & $\begin{array}{l}\text { Panic hardware does not require a key or } \\
\text { special tools to open from inside }\end{array}$ & Access & $\begin{array}{l}\text { Building } \\
\text { Egress }\end{array}$ \\
\hline Amber & $\begin{array}{l}\text { Allow access by the disabled to public or } \\
\text { work spaces in the facility }\end{array}$ & Accessibility & $\begin{array}{l}\text { ABA } \\
\text { compliance }\end{array}$ \\
\hline ISR-I Component & ISR-I Sub Component & ISR-I Priority & \\
\hline Lobby & Computer/LAN System & Medium & \\
\hline ISR-I Rating & ISR-I Criteria & BUILDER Category & $\begin{array}{l}\text { BUILDER Sub } \\
\text { Issue }\end{array}$ \\
\hline Green & $\begin{array}{l}\text { Enough LAN outlets are available to } \\
\text { support current mission requirements }\end{array}$ & Building Services & $\begin{array}{l}\text { Building IT } \\
\text { System }\end{array}$ \\
\hline Amber & Not enough LAN outlets are available & Building Services & $\begin{array}{l}\text { Building IT } \\
\text { System }\end{array}$ \\
\hline ISR-I Component & ISR-I Sub Component & ISR-I Priority & \\
\hline Lobby & Telephone System & Medium & \\
\hline ISR-I Rating & ISR-I Criteria & BUILDER Category & $\begin{array}{l}\text { BUILDER Sub } \\
\text { Issue }\end{array}$ \\
\hline Green & $\begin{array}{l}\text { Enough telephone jacks are available to } \\
\text { support current mission requirements }\end{array}$ & \multirow[t]{2}{*}{ Building Services } & $\begin{array}{l}\text { Building } \\
\text { Telephone } \\
\text { System }\end{array}$ \\
\hline Amber & Not enough telephone jacks are available & & $\begin{array}{l}\text { Building } \\
\text { Telephone } \\
\text { System }\end{array}$ \\
\hline ISR-I Component & ISR-I Sub Component & ISR-I Priority & \\
\hline ISR-I Rating & ISR-I Criteria & BUILDER Category & $\begin{array}{l}\text { BUILDER Sub } \\
\text { Issue }\end{array}$ \\
\hline \multirow[t]{2}{*}{ Green } & \multirow[t]{2}{*}{ ADAAG/UFAS compliant } & Accessibility & $\begin{array}{l}\text { ABA } \\
\text { compliance }\end{array}$ \\
\hline & & Access & $\begin{array}{l}\text { Directional } \\
\text { Info and } \\
\text { Signage }\end{array}$ \\
\hline \multirow[t]{2}{*}{ Amber } & ADAAG/UFAS compliant & Accessibility & $\begin{array}{l}\text { ABA } \\
\text { compliance }\end{array}$ \\
\hline & $\begin{array}{l}\text { Present, but not current; does not include a } \\
\text { building directory }\end{array}$ & \multirow[t]{2}{*}{ Access } & $\begin{array}{l}\text { Directional } \\
\text { Info and } \\
\text { Signage }\end{array}$ \\
\hline Red & $\begin{array}{l}\text { Does not meet AMBER column minimum } \\
\text { conditions }\end{array}$ & & $\begin{array}{l}\text { Directional } \\
\text { Info and } \\
\text { Signage }\end{array}$ \\
\hline ISR-I Component & ISR-I Sub Component & ISR-I Priority & \\
\hline Elevators & Saftey Standards & High & \\
\hline ISR-I Rating & ISR-I Criteria & BUILDER Category & $\begin{array}{l}\text { BUILDER Sub } \\
\text { Issue }\end{array}$ \\
\hline Green & $\begin{array}{l}\text { Emergency power circuits for lights, } \\
\text { speaker, telephones, and controls are } \\
\text { present and work well }\end{array}$ & Building Services & $\begin{array}{l}\text { Uninterruptib } \\
\text { le Power } \\
\text { Supply }\end{array}$ \\
\hline
\end{tabular}




\begin{tabular}{|c|c|c|c|}
\hline \multirow[t]{2}{*}{ Green } & \multirow{2}{*}{$\begin{array}{l}\text { Firefighter key control available } \\
\text { Controls and signals work and } \\
\text { accommodate the disabled }\end{array}$} & \multirow{2}{*}{$\begin{array}{l}\text { ATFP } \\
\text { Accessibility }\end{array}$} & $\begin{array}{l}\text { ATFP } \\
\text { Requirement } \\
\mathrm{s}\end{array}$ \\
\hline & & & $\begin{array}{l}\text { ABA } \\
\text { compliance }\end{array}$ \\
\hline ISR-I Component & ISR-I Sub Component & ISR-I Priority & \\
\hline Elevators & Capacity & High & \\
\hline ISR-I Rating & ISR-I Criteria & BUILDER Category & $\begin{array}{l}\text { BUILDER Sub } \\
\text { Issue }\end{array}$ \\
\hline \multirow[t]{2}{*}{ Green } & \multirow{2}{*}{$\begin{array}{l}\text { Accommodates a mobile stretcher for } \\
\text { medical emergencies } \\
\text { Number and size of elevators support } \\
\text { population served }\end{array}$} & \multirow{2}{*}{$\begin{array}{l}\text { Size and } \\
\text { Configuration } \\
\text { Size and } \\
\text { Configuration }\end{array}$} & $\begin{array}{l}\text { Building } \\
\text { Configuration }\end{array}$ \\
\hline & & & $\begin{array}{l}\text { Building } \\
\text { Configuration }\end{array}$ \\
\hline \multirow[t]{2}{*}{ Amber } & \multirow{3}{*}{$\begin{array}{l}\text { Accommodates a mobile stretcher for } \\
\text { medical emergencies } \\
\text { Number and size of elevators support } 75 \% \\
\text { of population served } \\
\text { Does not meet AMBER column minimum } \\
\text { conditions }\end{array}$} & \multirow{3}{*}{$\begin{array}{l}\text { Size and } \\
\text { Configuration } \\
\text { Size and } \\
\text { Configuration } \\
\text { Size and } \\
\text { Configuration }\end{array}$} & $\begin{array}{l}\text { Building } \\
\text { Configuration }\end{array}$ \\
\hline & & & $\begin{array}{l}\text { Building } \\
\text { Configuration }\end{array}$ \\
\hline Red & & & $\begin{array}{l}\text { Building } \\
\text { Configuration }\end{array}$ \\
\hline ISR-I Component & ISR-I Sub Component & ISR-I Priority & \\
\hline Elevators & Elevator Signage & Low & \\
\hline ISR-I Rating & ISR-I Criteria & BUILDER Category & $\begin{array}{l}\text { BUILDER Sub } \\
\text { Issue }\end{array}$ \\
\hline \multirow[t]{2}{*}{ Green } & ADAAG/UFAS compliant & Accessibility & $\begin{array}{l}\text { ABA } \\
\text { compliance }\end{array}$ \\
\hline & In place, inside and outside the Cabs & Access & $\begin{array}{l}\text { Directional } \\
\text { Info and } \\
\text { Signage }\end{array}$ \\
\hline \multirow[t]{2}{*}{ Green } & \multirow[b]{2}{*}{$\begin{array}{l}\text { Does not meet GREEN column mir } \\
\text { conditions }\end{array}$} & \multirow[t]{2}{*}{ Access } & $\begin{array}{l}\text { Directional } \\
\text { Info and } \\
\text { Signage }\end{array}$ \\
\hline & & & $\begin{array}{l}\text { Directional } \\
\text { Info and } \\
\text { Signage }\end{array}$ \\
\hline ISR-I Component & ISR-I Sub Component & ISR-I Priority & \\
\hline Corridors & Corridor Transit Area & High & \\
\hline ISR-I Rating & ISR-I Criteria & BUILDER Category & $\begin{array}{l}\text { BUILDER Sub } \\
\text { Issue }\end{array}$ \\
\hline \multirow[t]{2}{*}{ Green } & \multirow[t]{2}{*}{$\begin{array}{l}\text { Meets ADAAG/UFAS accessibility guidelines } \\
\text { and mission needs }\end{array}$} & \multirow[t]{2}{*}{ Accessibility } & $\begin{array}{l}\text { ABA } \\
\text { compliance }\end{array}$ \\
\hline & & & $\begin{array}{l}\text { ATFP } \\
\text { Requirement } \\
\mathrm{s}\end{array}$ \\
\hline \multirow[t]{2}{*}{ Amber } & \multirow[t]{2}{*}{$\begin{array}{l}\text { Meets ADAAG/UFAS accessibility guidelines } \\
\text { and mission needs }\end{array}$} & \multirow[t]{2}{*}{ Accessibility } & $\begin{array}{l}\text { ABA } \\
\text { compliance }\end{array}$ \\
\hline & & & $\begin{array}{l}\text { ATFP } \\
\text { Requirement } \\
\mathrm{s}\end{array}$ \\
\hline ISR-I Component & ISR-I Sub Component & ISR-I Priority & \\
\hline
\end{tabular}




\begin{tabular}{|c|c|c|c|}
\hline Corridors & Lighting and Outlets & \multicolumn{2}{|l|}{ High } \\
\hline ISR-I Rating & ISR-I Criteria & BUILDER Category & $\begin{array}{l}\text { BUILDER Sub } \\
\text { Issue }\end{array}$ \\
\hline \multirow[t]{2}{*}{ Green } & \multirow{2}{*}{$\begin{array}{l}\text { Overhead, emergency, and exit lighting is } \\
\text { available; more than } 90 \% \text { is working } \\
\text { At least one electrical duplex (three prong } \\
\text { grounded) outlet on all wall surfaces }\end{array}$} & Access & $\begin{array}{l}\text { Directional } \\
\text { Info and } \\
\text { Signage }\end{array}$ \\
\hline & & Building Services & $\begin{array}{l}\text { Electrical } \\
\text { Grounding } \\
\text { System }\end{array}$ \\
\hline Amber & $\begin{array}{l}\text { One or more walls lack grounded duplex } \\
\text { outlets }\end{array}$ & Building Services & $\begin{array}{l}\text { Electrical } \\
\text { Grounding } \\
\text { System }\end{array}$ \\
\hline ISR-I Component & ISR-I Sub Component & ISR-I Priority & \\
\hline Corridors & Corridor Doors & High & \\
\hline ISR-I Rating & ISR-I Criteria & BUILDER Category & $\begin{array}{l}\text { BUILDER Sub } \\
\text { Issue }\end{array}$ \\
\hline Green & $\begin{array}{l}\text { ADAAG/UFAS accessibility to public or work } \\
\text { spaces in the facility }\end{array}$ & Accessibility & $\begin{array}{l}\text { ABA } \\
\text { compliance }\end{array}$ \\
\hline \multirow[t]{2}{*}{ Green } & \multirow{2}{*}{$\begin{array}{l}\text { Doors have lever handles or push-plates } \\
\text { Interior doors that are also fire/exit doors, } \\
\text { and normally in an open position, are } \\
\text { equipped with automatic closure devices } \\
\text { and panic hardware }\end{array}$} & \multirow[t]{2}{*}{ Accessibility } & $\begin{array}{l}\text { ABA } \\
\text { compliance }\end{array}$ \\
\hline & & & $\begin{array}{l}\text { ATFP } \\
\text { Requirement } \\
\mathrm{s}\end{array}$ \\
\hline Green & $\begin{array}{l}\text { Interior doors that exit to the exterior are } \\
\text { metal or solid core wood and open easily } \\
\text { from the inside }\end{array}$ & & $\begin{array}{l}\text { ATFP } \\
\text { Requirement } \\
\mathrm{s}\end{array}$ \\
\hline Green & \multirow{2}{*}{$\begin{array}{l}\text { Panic hardware does not require a key or } \\
\text { special tools to open from inside } \\
\text { ADAAG/UFAS accessibility to public or work } \\
\text { spaces in the facility }\end{array}$} & ATFP & $\begin{array}{l}\text { Building } \\
\text { Egress }\end{array}$ \\
\hline Amber & & Accessibility & $\begin{array}{l}\text { ABA } \\
\text { compliance }\end{array}$ \\
\hline ISR-I Component & ISR-I Sub Component & ISR-I Priority & \\
\hline Corridors & Corridor Signage & Low & \\
\hline ISR-I Rating & ISR-I Criteria & BUILDER Category & $\begin{array}{l}\text { BUILDER Sub } \\
\text { Issue }\end{array}$ \\
\hline \multirow[t]{2}{*}{ Green } & \multirow[t]{2}{*}{ ADAAG/UFAS compliant } & \multirow[t]{2}{*}{ Accessibility } & $\begin{array}{l}\text { ABA } \\
\text { compliance }\end{array}$ \\
\hline & & & $\begin{array}{l}\text { Directional } \\
\text { Info and } \\
\text { Signage }\end{array}$ \\
\hline \multirow[t]{2}{*}{ Amber } & ADAAG/UFAS compliant & Accessibility & $\begin{array}{l}\text { ABA } \\
\text { compliance }\end{array}$ \\
\hline & \multirow[b]{2}{*}{$\begin{array}{l}\text { Does not meet AMBER column minimum } \\
\text { conditions }\end{array}$} & \multirow[t]{2}{*}{ Access } & $\begin{array}{l}\text { Directional } \\
\text { Info and } \\
\text { Signage }\end{array}$ \\
\hline Red & & & $\begin{array}{l}\text { Directional } \\
\text { Info and } \\
\text { Signage }\end{array}$ \\
\hline ISR-I Component & ISR-I Sub Component & ISR-I Priority & \\
\hline
\end{tabular}




\begin{tabular}{|c|c|c|c|}
\hline Stairs & Landings and Treads & High & \\
\hline ISR-I Rating & ISR-I Criteria & BUILDER Category & $\begin{array}{l}\text { BUILDER Sub } \\
\text { Issue }\end{array}$ \\
\hline \multirow[t]{2}{*}{ Green } & \multirow{4}{*}{$\begin{array}{l}\text { Covered with non-skid material } \\
\text { Push plate or lever handle hardware on } \\
\text { corridor side } \\
\text { Panic hardware does not require key or } \\
\text { special tools to operate from inside } \\
\text { Panic hardware requires key or special } \\
\text { tools to operate from inside }\end{array}$} & Access & $\begin{array}{l}\text { Building } \\
\text { Egress }\end{array}$ \\
\hline & & Accessibility & $\begin{array}{l}\text { ABA } \\
\text { compliance }\end{array}$ \\
\hline \multirow[t]{2}{*}{ Green } & & \multirow[t]{2}{*}{ Access } & $\begin{array}{l}\text { Building } \\
\text { Egress }\end{array}$ \\
\hline & & & $\begin{array}{l}\text { Building } \\
\text { Egress }\end{array}$ \\
\hline ISR-I Component & ISR-I Sub Component & ISR-I Priority & \\
\hline Stairs & Lighting and Outlets & High & \\
\hline ISR-I Rating & ISR-I Criteria & BUILDER Category & $\begin{array}{l}\text { BUILDER Sub } \\
\text { Issue }\end{array}$ \\
\hline \multirow[t]{2}{*}{ Green } & \multirow[t]{2}{*}{$\begin{array}{l}\text { Exit and emergency lights are in place and } \\
\text { working, and tied to backup power, either } \\
\text { emergency generator or battery }\end{array}$} & Access & $\begin{array}{l}\text { Building } \\
\text { Egress }\end{array}$ \\
\hline & & Building Services & $\begin{array}{l}\text { Electrical } \\
\text { Grounding } \\
\text { System }\end{array}$ \\
\hline \multirow[t]{2}{*}{ Amber } & \multirow[t]{2}{*}{$\begin{array}{l}\text { Exit and emergency lights are in place, at } \\
\text { least } 75 \% \text { are working, and are tied to } \\
\text { backup power, either emergency generator } \\
\text { or battery }\end{array}$} & \multirow[b]{2}{*}{ Building Services } & $\begin{array}{l}\text { Building } \\
\text { Egress }\end{array}$ \\
\hline & & & $\begin{array}{l}\text { Electrical } \\
\text { Grounding } \\
\text { System }\end{array}$ \\
\hline ISR-I Component & ISR-I Sub Component & ISR-I Priority & \\
\hline Stairs & Signage & Low & \\
\hline ISR-I Rating & ISR-I Criteria & BUILDER Category & $\begin{array}{l}\text { BUILDER Sub } \\
\text { Issue }\end{array}$ \\
\hline \multirow[t]{2}{*}{ Green } & \multirow[t]{2}{*}{ ADAAG/UFAS compliant } & Accessibility & $\begin{array}{l}\text { ABA } \\
\text { compliance }\end{array}$ \\
\hline & & Access & $\begin{array}{l}\text { Directional } \\
\text { Info and } \\
\text { Signage }\end{array}$ \\
\hline \multirow[t]{2}{*}{ Amber } & ADAAG/UFAS compliant & Accessibility & $\begin{array}{l}\text { ABA } \\
\text { compliance }\end{array}$ \\
\hline & \multirow{2}{*}{$\begin{array}{l}\text { Present, but not current } \\
\text { Does not meet AMBER column minimum } \\
\text { conditions }\end{array}$} & \multirow[t]{2}{*}{ Access } & $\begin{array}{l}\text { Building } \\
\text { Entry }\end{array}$ \\
\hline Red & & & $\begin{array}{l}\text { Building } \\
\text { Entry }\end{array}$ \\
\hline ISR-I Component & ISR-I Sub Component & ISR-I Priority & \\
\hline \multicolumn{3}{|l|}{ Administrative } & \\
\hline ISR-I Rating & ISR-I Criteria & BUILDER Category & $\begin{array}{l}\text { BUILDER Sub } \\
\text { Issue }\end{array}$ \\
\hline
\end{tabular}




\begin{tabular}{|c|c|c|c|}
\hline Green & ADAAG/UFAS compliant & Accessibility & $\begin{array}{l}\text { ABA } \\
\text { compliance }\end{array}$ \\
\hline Green & Flexible layout; space meets mission needs & $\begin{array}{l}\text { Size and } \\
\text { Configuration }\end{array}$ & $\begin{array}{l}\text { Building } \\
\text { Configuration }\end{array}$ \\
\hline Green & $\begin{array}{l}\text { Sufficient storage space, close to work } \\
\text { stations, meets mission needs }\end{array}$ & $\begin{array}{l}\text { Size and } \\
\text { Configuration }\end{array}$ & Overcrowding \\
\hline Amber & ADAAG/UFAS compliant & Accessibility & $\begin{array}{l}\text { ABA } \\
\text { compliance }\end{array}$ \\
\hline Amber & Space restricts aisle and workstation layout & $\begin{array}{l}\text { Size and } \\
\text { Configuration }\end{array}$ & $\begin{array}{l}\text { Occupant } \\
\text { Interaction }\end{array}$ \\
\hline Amber & $\begin{array}{l}\text { Marginal storage space, not close to } \\
\text { workstations, but meets mission needs }\end{array}$ & $\begin{array}{l}\text { Size and } \\
\text { Configuration }\end{array}$ & $\begin{array}{l}\text { Building } \\
\text { Configuration }\end{array}$ \\
\hline Red & $\begin{array}{l}\text { Does not meet AMBER column minimum } \\
\text { conditions }\end{array}$ & $\begin{array}{l}\text { Size and } \\
\text { Configuration }\end{array}$ & $\begin{array}{l}\text { Building } \\
\text { Configuration }\end{array}$ \\
\hline ISR-I Component & ISR-I Sub Component & ISR-I Priority & \\
\hline $\begin{array}{l}\text { Administrative } \\
\text { Areas }\end{array}$ & Lighting and Outlets & High & \\
\hline ISR-I Rating & ISR-I Criteria & BUILDER Category & $\begin{array}{l}\text { BUILDER Sub } \\
\text { Issue }\end{array}$ \\
\hline Green & $\begin{array}{l}\text { At least one electrical duplex (three prong } \\
\text { grounded) outlet at all workstations }\end{array}$ & Building Services & $\begin{array}{l}\text { Building } \\
\text { Telephone } \\
\text { System }\end{array}$ \\
\hline Green & $\begin{array}{l}\text { Besides workstations, there is at least one } \\
\text { electrical duplex outlet on all interior walls } \\
\text { of the area }\end{array}$ & Building Services & $\begin{array}{l}\text { Electrical } \\
\text { Distribution }\end{array}$ \\
\hline Amber & $\begin{array}{l}\text { One or more workstations lack grounded } \\
\text { duplex outlets }\end{array}$ & Building Services & $\begin{array}{l}\text { Electrical } \\
\text { Grounding } \\
\text { System }\end{array}$ \\
\hline Amber & $\begin{array}{l}\text { Besides work stations, there is at least one } \\
\text { electrical duplex outlet on } 1 \text { wall of the } \\
\text { area }\end{array}$ & Building Services & $\begin{array}{l}\text { Electrical } \\
\text { Distribution }\end{array}$ \\
\hline ISR-I Component & ISR-I Sub Component & ISR-I Priority & \\
\hline $\begin{array}{l}\text { Administrative } \\
\text { Areas }\end{array}$ & Computer/LAN system & High & \\
\hline ISR-I Rating & ISR-I Criteria & BUILDER Category & $\begin{array}{l}\text { BUILDER Sub } \\
\text { Issue }\end{array}$ \\
\hline Green & $\begin{array}{l}\text { Enough LAN outlets are available to } \\
\text { support current mission requirements }\end{array}$ & Building Services & $\begin{array}{l}\text { Building IT } \\
\text { System }\end{array}$ \\
\hline Amber & Not enough LAN outlets are available & Building Services & $\begin{array}{l}\text { Building IT } \\
\text { System }\end{array}$ \\
\hline Red & If required, LAN outlets are not available & Building Services & $\begin{array}{l}\text { Building IT } \\
\text { System }\end{array}$ \\
\hline ISR-I Component & ISR-I Sub Component & ISR-I Priority & \\
\hline $\begin{array}{l}\text { Administrative } \\
\text { Areas }\end{array}$ & Telephone Systems & High & \\
\hline ISR-I Rating & ISR-I Criteria & BUILDER Category & $\begin{array}{l}\text { BUILDER Sub } \\
\text { Issue }\end{array}$ \\
\hline
\end{tabular}




\begin{tabular}{|c|c|c|c|}
\hline \multirow[b]{2}{*}{ Amber } & $\begin{array}{l}\text { Enough telephone jacks are available to } \\
\text { support current mission requirements }\end{array}$ & \multirow[t]{2}{*}{ Building Services } & $\begin{array}{l}\text { Building } \\
\text { Telephone } \\
\text { System }\end{array}$ \\
\hline & \multirow[t]{2}{*}{ Not enough telephone jacks are available } & & $\begin{array}{l}\text { Building } \\
\text { Telephone } \\
\text { System }\end{array}$ \\
\hline Red & & Building Services & $\begin{array}{l}\text { Building } \\
\text { Telephone } \\
\text { System }\end{array}$ \\
\hline ISR-I Component & ISR-I Sub Component & ISR-I Priority & \\
\hline $\begin{array}{l}\text { Administrative } \\
\text { Areas }\end{array}$ & Interior Doors & Medium & \\
\hline ISR-I Rating & ISR-I Criteria & BUILDER Category & $\begin{array}{l}\text { BUILDER Sub } \\
\text { Issue }\end{array}$ \\
\hline Green & Doors have lever handles & Accessibility & $\begin{array}{l}\text { ABA } \\
\text { compliance }\end{array}$ \\
\hline Green & $\begin{array}{l}\text { Allow access by the disabled to public or } \\
\text { work spaces in the facility }\end{array}$ & Accessibility & $\begin{array}{l}\text { ABA } \\
\text { compliance }\end{array}$ \\
\hline Green & $\begin{array}{l}\text { Doors that exit to the exterior are equipped } \\
\text { with fire/exit signs and panic hardware }\end{array}$ & Access & $\begin{array}{l}\text { Building } \\
\text { Egress }\end{array}$ \\
\hline Amber & $\begin{array}{l}\text { Allow access by the disabled to public or } \\
\text { work spaces in the facility }\end{array}$ & Accessibility & $\begin{array}{l}\text { ABA } \\
\text { compliance }\end{array}$ \\
\hline Amber & $\begin{array}{l}\text { Doors that exit to the exterior are equipped } \\
\text { with fire/exit signs and panic hardware }\end{array}$ & Access & $\begin{array}{l}\text { Building } \\
\text { Egress }\end{array}$ \\
\hline ISR-I Component & ISR-I Sub Component & ISR-I Priority & \\
\hline $\begin{array}{l}\text { Administrative } \\
\text { Areas }\end{array}$ & Signage & Low & \\
\hline ISR-I Rating & ISR-I Criteria & BUILDER Category & $\begin{array}{l}\text { BUILDER Sub } \\
\text { Issue }\end{array}$ \\
\hline Green & ADAAG/UFAS compliant & Accessibility & $\begin{array}{l}\text { ABA } \\
\text { compliance }\end{array}$ \\
\hline Amber & ADAAG/UFAS compliant & Accessibility & $\begin{array}{l}\text { ABA } \\
\text { compliance }\end{array}$ \\
\hline ISR-I Component & ISR-I Sub Component & ISR-I Priority & \\
\hline $\begin{array}{l}\text { Bathrooms/Show } \\
\text { ers }\end{array}$ & Plumbing Fixtures & High & \\
\hline ISR-I Rating & ISR-I Criteria & BUILDER Category & $\begin{array}{l}\text { BUILDER Sub } \\
\text { Issue }\end{array}$ \\
\hline Green & Ample hot water & Building Services & $\begin{array}{l}\text { Hot Water } \\
\text { Supply }\end{array}$ \\
\hline Green & Dependable and adequate water pressure & Building Services & $\begin{array}{l}\text { Building } \\
\text { Water Supply }\end{array}$ \\
\hline Amber & Lukewarm "hot" water & Building Services & $\begin{array}{l}\text { Hot Water } \\
\text { Supply }\end{array}$ \\
\hline Amber & Low water pressure & Building Services & $\begin{array}{l}\text { Building } \\
\text { Water Supply }\end{array}$ \\
\hline ISR-I Component & ISR-I Sub Component & ISR-I Priority & \\
\hline $\begin{array}{l}\text { Bathrooms/Show } \\
\text { ers }\end{array}$ & Bathrooms/Showers Configuration & High & \\
\hline
\end{tabular}




\begin{tabular}{|c|c|c|c|}
\hline ISR-I Rating & ISR-I Criteria & BUILDER Category & $\begin{array}{l}\text { BUILDER Sub } \\
\text { Issue }\end{array}$ \\
\hline \multirow[t]{2}{*}{ Green } & \multirow{3}{*}{$\begin{array}{l}\text { Private bathroom for each bedroom } \\
\text { All bathrooms must be sized to the } \\
\text { ADAAG/UFAS standard } \\
\text { A minimum of } 10 \% \text { of total bathrooms in } \\
\text { the facility are ADAAG/UFAS compliant }\end{array}$} & \multirow[t]{2}{*}{$\begin{array}{l}\text { Size and } \\
\text { Configuration }\end{array}$} & Overcrowding \\
\hline & & & $\begin{array}{l}\text { ABA } \\
\text { compliance }\end{array}$ \\
\hline Green & & Accessibility & $\begin{array}{l}\text { ABA } \\
\text { compliance }\end{array}$ \\
\hline \multirow[t]{2}{*}{ Amber } & \multirow{2}{*}{$\begin{array}{l}\text { Shared bathroom } \\
\text { A minimum of } 10 \% \text { of total bathrooms in } \\
\text { the facility are ADAAG/UFAS compliant }\end{array}$} & \multirow[t]{2}{*}{$\begin{array}{l}\text { Size and } \\
\text { Configuration }\end{array}$} & Overcrowding \\
\hline & & & $\begin{array}{l}\text { ABA } \\
\text { compliance }\end{array}$ \\
\hline ISR-I Component & ISR-I Sub Component & ISR-I Priority & \\
\hline $\begin{array}{l}\text { Bathrooms/Show } \\
\text { ers }\end{array}$ & Ventilation & \multicolumn{2}{|l|}{ High } \\
\hline ISR-I Rating & ISR-I Criteria & BUILDER Category & $\begin{array}{l}\text { BUILDER Sub } \\
\text { Issue }\end{array}$ \\
\hline Green & \multirow{3}{*}{$\begin{array}{l}\text { Ventilation integrated into forced air } \\
\text { system } \\
\text { Fans provided, but not integrated into } \\
\text { forced air system } \\
\text { Does not meet AMBER column minimum } \\
\text { conditions }\end{array}$} & Comfort & $\begin{array}{l}\text { Ventilation } \\
\text { Capacity }\end{array}$ \\
\hline Amber & & \multirow[t]{2}{*}{ Comfort } & $\begin{array}{l}\text { Ventilation } \\
\text { Capacity }\end{array}$ \\
\hline Red & & & $\begin{array}{l}\text { Ventilation } \\
\text { Capacity }\end{array}$ \\
\hline ISR-I Component & ISR-I Sub Component & ISR-I Priority & \\
\hline $\begin{array}{l}\text { Bathrooms/Show } \\
\text { ers }\end{array}$ & Lighting and Outlets & \multicolumn{2}{|l|}{ High } \\
\hline ISR-I Rating & ISR-I Criteria & BUILDER Category & $\begin{array}{l}\text { BUILDER Sub } \\
\text { Issue }\end{array}$ \\
\hline \multirow[t]{2}{*}{ Green } & \multirow[t]{2}{*}{$\begin{array}{l}\text { All outlets grounded/GFI rated available } \\
\text { where water may be present }\end{array}$} & \multirow[t]{2}{*}{ Building Services } & $\begin{array}{l}\text { Electrical } \\
\text { Grounding } \\
\text { System }\end{array}$ \\
\hline & & & $\begin{array}{l}\text { Electrical } \\
\text { Grounding } \\
\text { System }\end{array}$ \\
\hline ISR-I Component & ISR-I Sub Component & ISR-I Priority & \\
\hline $\begin{array}{l}\text { Bathrooms/Show } \\
\text { ers }\end{array}$ & Doors & Medium & \\
\hline ISR-I Rating & ISR-I Criteria & BUILDER Category & $\begin{array}{l}\text { BUILDER Sub } \\
\text { Issue }\end{array}$ \\
\hline Green & $\begin{array}{l}\text { Fully functional, with lever handles, push } \\
\text { plates and kick-plates }\end{array}$ & Accessibility & $\begin{array}{l}\text { ABA } \\
\text { compliance }\end{array}$ \\
\hline ISR-I Component & ISR-I Sub Component & ISR-I Priority & \\
\hline $\begin{array}{l}\text { Bathrooms/Show } \\
\text { ers }\end{array}$ & Bathroom Accessories & Low & \\
\hline ISR-I Rating & ISR-I Criteria & BUILDER Category & $\begin{array}{l}\text { BUILDER Sub } \\
\text { Issue }\end{array}$ \\
\hline
\end{tabular}




\begin{tabular}{|c|c|c|c|}
\hline Green & $\begin{array}{l}\text { Dispensers for hand soap, towels, toilet } \\
\text { paper, disposal containers for hygiene } \\
\text { products, etc., are present and easily } \\
\text { accessible }\end{array}$ & $\begin{array}{l}\text { Missing or } \\
\text { Improper } \\
\text { Components }\end{array}$ & $\begin{array}{l}\text { Missing } \\
\text { Components } \\
?\end{array}$ \\
\hline Amber & $\begin{array}{l}\text { Accessories are available, but difficult to } \\
\text { access }\end{array}$ & Accessibility & $\begin{array}{l}\text { ABA } \\
\text { compliance }\end{array}$ \\
\hline ISR-I Component & ISR-I Sub Component & ISR-I Priority & \\
\hline Fire Protection & Sprinklers (Records Check) & High & \\
\hline ISR-I Rating & ISR-I Criteria & BUILDER Category & $\begin{array}{l}\text { BUILDER Sub } \\
\text { Issue }\end{array}$ \\
\hline Red & $\begin{array}{l}\text { Local Fire Marshal requires replacement of } \\
\text { system }\end{array}$ & $\begin{array}{l}\text { Environmental/He } \\
\text { alth }\end{array}$ & $\begin{array}{l}\text { Fire } \\
\text { Suppression }\end{array}$ \\
\hline ISR-I Component & ISR-I Sub Component & ISR-I Priority & \\
\hline Fire Protection & Fire Alarm Systems & High & \\
\hline ISR-I Rating & ISR-I Criteria & BUILDER Category & $\begin{array}{l}\text { BUILDER Sub } \\
\text { Issue }\end{array}$ \\
\hline Green & $\begin{array}{l}\text { Emergency notification system considers } \\
\text { auditory and visual impairments and } \\
\text { ensures strobe lights and audible alarms } \\
\text { are in each living/sleeping room }\end{array}$ & $\begin{array}{l}\text { Environmental/He } \\
\text { alth }\end{array}$ & $\begin{array}{l}\text { Fire/Smoke } \\
\text { Detection }\end{array}$ \\
\hline ISR-I Component & ISR-I Sub Component & ISR-I Priority & \\
\hline Fire Protection & Standpipe System (Records Check) & Medium & \\
\hline ISR-I Rating & ISR-I Criteria & BUILDER Category & $\begin{array}{l}\text { BUILDER Sub } \\
\text { Issue }\end{array}$ \\
\hline Red & No standpipe system & $\begin{array}{l}\text { Environmental/He } \\
\text { alth }\end{array}$ & $\begin{array}{l}\text { Fire } \\
\text { Suppression }\end{array}$ \\
\hline Red & $\begin{array}{l}\text { Local Fire Marshal requires replacement of } \\
\text { system }\end{array}$ & $\begin{array}{l}\text { Environmental/He } \\
\text { alth }\end{array}$ & $\begin{array}{l}\text { Fire } \\
\text { Suppression }\end{array}$ \\
\hline ISR-I Component & ISR-I Sub Component & ISR-I Priority & \\
\hline Fire Protection & Smoke/Heat Sensing Detectors & Medium & \\
\hline ISR-I Rating & ISR-I Criteria & BUILDER Category & $\begin{array}{l}\text { BUILDER Sub } \\
\text { Issue }\end{array}$ \\
\hline Green & $\begin{array}{l}\text { If required, there is a central fire control } \\
\text { panel for the facility that indicates where in } \\
\text { the facility a detector is sensing heat or } \\
\text { smoke (floor, zone, ceiling space, } \\
\text { ductwork) }\end{array}$ & $\begin{array}{l}\text { Environmental/He } \\
\text { alth }\end{array}$ & $\begin{array}{l}\text { Fire/Smoke } \\
\text { Detection }\end{array}$ \\
\hline Green & Alerts a Central Fire Station & $\begin{array}{l}\text { Environmental/He } \\
\text { alth }\end{array}$ & $\begin{array}{l}\text { Fire/Smoke } \\
\text { Detection }\end{array}$ \\
\hline Amber & $\begin{array}{l}\text { If required, there is central fire control } \\
\text { panel, but it indicates only that an alarm } \\
\text { initiated at a particular floor or zone; } \\
\text { ceilings, ductwork, etc., are not alarmed }\end{array}$ & $\begin{array}{l}\text { Environmental/He } \\
\text { alth }\end{array}$ & $\begin{array}{l}\text { Fire/Smoke } \\
\text { Detection }\end{array}$ \\
\hline Red & $\begin{array}{l}\text { Though required, there is no central fire } \\
\text { control panel for the facility }\end{array}$ & $\begin{array}{l}\text { Environmental/He } \\
\text { alth }\end{array}$ & $\begin{array}{l}\text { Fire/Smoke } \\
\text { Detection }\end{array}$ \\
\hline Red & Does not alert a Central Fire Station & $\begin{array}{l}\text { Environmental/He } \\
\text { alth }\end{array}$ & $\begin{array}{l}\text { Fire/Smoke } \\
\text { Detection }\end{array}$ \\
\hline ISR-I Component & ISR-I Sub Component & ISR-I Priority & \\
\hline Lounge & Lighting and Outlets & High & \\
\hline
\end{tabular}




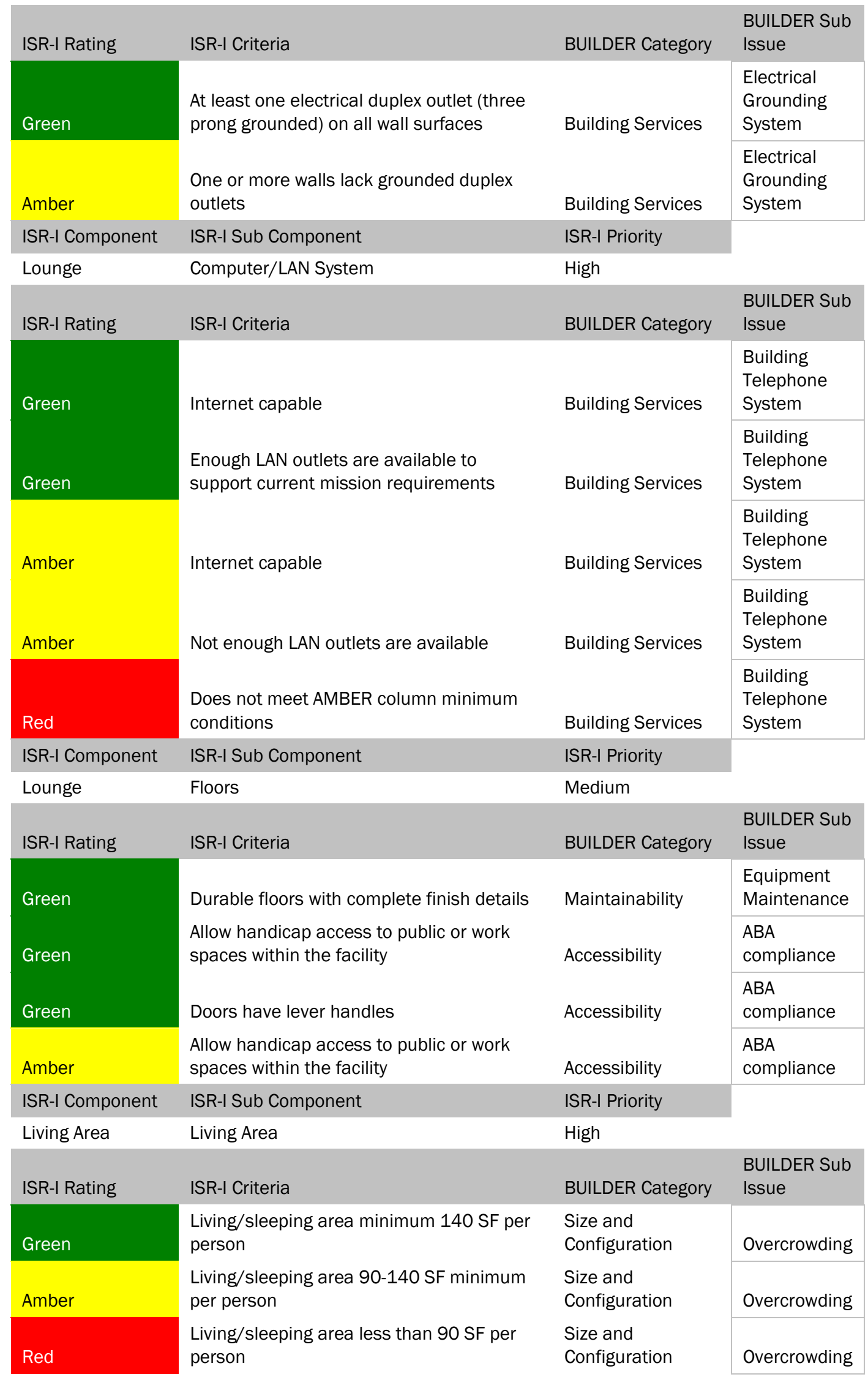




\begin{tabular}{|c|c|c|c|}
\hline ISR-I Component & ISR-I Sub Component & ISR-I Priority & \\
\hline Living Area & Lighting and Outlets & High & \\
\hline ISR-I Rating & ISR-I Criteria & BUILDER Category & $\begin{array}{l}\text { BUILDER Sub } \\
\text { Issue }\end{array}$ \\
\hline \multirow[t]{2}{*}{ Green } & $\begin{array}{l}\text { At least one electrical duplex outlet (three } \\
\text { prong grounded) on all wall surfaces }\end{array}$ & \multirow[t]{2}{*}{ Building Services } & $\begin{array}{l}\text { Electrical } \\
\text { Grounding } \\
\text { System }\end{array}$ \\
\hline & $\begin{array}{l}\text { One or more walls lack grounded duplex } \\
\text { outlets }\end{array}$ & & $\begin{array}{l}\text { Electrical } \\
\text { Grounding } \\
\text { System }\end{array}$ \\
\hline ISR-I Component & ISR-I Sub Component & ISR-I Priority & \\
\hline Living Area & Telephone System & High & \\
\hline ISR-I Rating & ISR-I Criteria & BUILDER Category & $\begin{array}{l}\text { BUILDER Sub } \\
\text { Issue }\end{array}$ \\
\hline \multirow[t]{2}{*}{ Green } & \multirow[t]{2}{*}{ Teletype capable wiring } & \multirow[t]{2}{*}{ Building Services } & $\begin{array}{l}\text { Building } \\
\text { Telephone } \\
\text { System }\end{array}$ \\
\hline & & & $\begin{array}{l}\text { Building } \\
\text { Telephone } \\
\text { System }\end{array}$ \\
\hline Green & At least one phone jack is available & Building Services & $\begin{array}{l}\text { Building } \\
\text { Telephone } \\
\text { System }\end{array}$ \\
\hline ISR-I Component & ISR-I Sub Component & ISR-I Priority & \\
\hline Living Area & Computer/LAN System & High & \\
\hline ISR-I Rating & ISR-I Criteria & BUILDER Category & $\begin{array}{l}\text { BUILDER Sub } \\
\text { Issue }\end{array}$ \\
\hline Green & \multirow[b]{2}{*}{$\begin{array}{l}\text { Enough LAN outlets are available to } \\
\text { support current mission requirements }\end{array}$} & Building Services & $\begin{array}{l}\text { Building } \\
\text { Telephone } \\
\text { System }\end{array}$ \\
\hline Green & & Building Services & $\begin{array}{l}\text { Building } \\
\text { Telephone } \\
\text { System }\end{array}$ \\
\hline \multirow[t]{2}{*}{ Amber } & Internet connectivity available & Building Services & $\begin{array}{l}\text { Building } \\
\text { Telephone } \\
\text { System }\end{array}$ \\
\hline & Not enough LAN outlets are available & \multirow[t]{2}{*}{ Building Services } & $\begin{array}{l}\text { Building } \\
\text { Telephone } \\
\text { System }\end{array}$ \\
\hline Red & $\begin{array}{l}\text { Does not meet AMBER column minimum } \\
\text { conditions }\end{array}$ & & $\begin{array}{l}\text { Building } \\
\text { Telephone } \\
\text { System }\end{array}$ \\
\hline ISR-I Component & ISR-I Sub Component & ISR-I Priority & \\
\hline Living Area & Doors & High & \\
\hline ISR-I Rating & ISR-I Criteria & BUILDER Category & $\begin{array}{l}\text { BUILDER Sub } \\
\text { Issue }\end{array}$ \\
\hline Green & $\begin{array}{l}\text { Allows handicap access to public or work } \\
\text { spaces within the facility }\end{array}$ & Accessibility & $\begin{array}{l}\text { ABA } \\
\text { compliance }\end{array}$ \\
\hline
\end{tabular}




\begin{tabular}{|c|c|c|c|}
\hline Green & \multirow{2}{*}{$\begin{array}{l}\text { Doors have lever handles } \\
\text { Allows handicap access to public or work } \\
\text { spaces within the facility }\end{array}$} & \multirow{2}{*}{$\begin{array}{l}\text { Accessibility } \\
\text { Accessibility }\end{array}$} & $\begin{array}{l}\text { ABA } \\
\text { compliance }\end{array}$ \\
\hline Amber & & & $\begin{array}{l}\text { ABA } \\
\text { compliance }\end{array}$ \\
\hline ISR-I Component & ISR-I Sub Component & ISR-I Priority & \\
\hline Living Area & Floors & Medium & \\
\hline ISR-I Rating & ISR-I Criteria & BUILDER Category & $\begin{array}{l}\text { BUILDER Sub } \\
\text { Issue }\end{array}$ \\
\hline Green & Durable floors with complete finish details & Maintainability & $\begin{array}{l}\text { Equipment } \\
\text { Maintenance }\end{array}$ \\
\hline ISR-I Component & ISR-I Sub Component & ISR-I Priority & \\
\hline Living Area & HVAC Controls & Medium & \\
\hline ISR-I Rating & ISR-I Criteria & BUILDER Category & $\begin{array}{l}\text { BUILDER Sub } \\
\text { Issue }\end{array}$ \\
\hline Green & $\begin{array}{l}\text { Each sleeping area has individual climate } \\
\text { controls }\end{array}$ & Comfort & $\begin{array}{l}\text { HVAC } \\
\text { Controls }\end{array}$ \\
\hline Amber & $\begin{array}{l}10 \% \text { or more of sleeping area has } \\
\text { individual climate controls }\end{array}$ & Comfort & $\begin{array}{l}\text { HVAC } \\
\text { Controls }\end{array}$ \\
\hline ISR-I Component & ISR-I Sub Component & ISR-I Priority & \\
\hline Kitchenette & Kitchenette & Medium & \\
\hline ISR-I Rating & ISR-I Criteria & BUILDER Category & $\begin{array}{l}\text { BUILDER Sub } \\
\text { Issue }\end{array}$ \\
\hline Green & $\begin{array}{l}\text { Standard kitchen with range, microwave } \\
\text { oven, garbage disposal, standard size } \\
\text { refrigerator, and counter seating }\end{array}$ & $\begin{array}{l}\text { Size and } \\
\text { Configuration }\end{array}$ & Overcrowding \\
\hline Green & $\begin{array}{l}\text { Kitchen for disabled Soldier meets } \\
\text { accessibility requirement }\end{array}$ & Accessibility & $\begin{array}{l}\text { ABA } \\
\text { compliance }\end{array}$ \\
\hline Green & Space meets mission needs & $\begin{array}{l}\text { Size and } \\
\text { Configuration }\end{array}$ & Overcrowding \\
\hline Amber & $\begin{array}{l}\text { Kitchen or kitchenette provided, but does } \\
\text { not meet GREEN column minimum } \\
\text { conditions }\end{array}$ & Accessibility & $\begin{array}{l}\text { ABA } \\
\text { compliance }\end{array}$ \\
\hline Red & No Kitchen or Kitchenette provided & $\begin{array}{l}\text { Missing or } \\
\text { Improper } \\
\text { Components }\end{array}$ & $\begin{array}{l}\text { Missing } \\
\text { Components } \\
?\end{array}$ \\
\hline ISR-I Component & ISR-I Sub Component & ISR-I Priority & \\
\hline Kitchenette & Plumbing Fixtures & High & \\
\hline ISR-I Rating & ISR-I Criteria & BUILDER Category & $\begin{array}{l}\text { BUILDER Sub } \\
\text { Issue }\end{array}$ \\
\hline Green & Lever actuated faucets & Accessibility & $\begin{array}{l}\text { ABA } \\
\text { compliance }\end{array}$ \\
\hline Green & Ample hot water & Building Services & $\begin{array}{l}\text { Hot Water } \\
\text { Supply }\end{array}$ \\
\hline Green & Dependable and adequate water pressure & Building Services & $\begin{array}{l}\text { Building } \\
\text { Water Supply }\end{array}$ \\
\hline Amber & Lever actuated faucets & Accessibility & $\begin{array}{l}\text { ABA } \\
\text { compliance }\end{array}$ \\
\hline
\end{tabular}




\begin{tabular}{|c|c|c|c|}
\hline \multirow[t]{2}{*}{ Amber } & \multirow[t]{2}{*}{ Lukewarm "hot” water } & \multirow{2}{*}{$\begin{array}{l}\text { Building Services } \\
\text { Building Services }\end{array}$} & $\begin{array}{l}\text { Hot Water } \\
\text { Supply }\end{array}$ \\
\hline & & & $\begin{array}{l}\text { Building } \\
\text { Water Supply }\end{array}$ \\
\hline ISR-I Component & ISR-I Sub Component & ISR-I Priority & \\
\hline Kitchenette & Lighting and Outlets & High & \\
\hline ISR-I Rating & ISR-I Criteria & BUILDER Category & $\begin{array}{l}\text { BUILDER Sub } \\
\text { Issue }\end{array}$ \\
\hline \multirow[t]{2}{*}{ Green } & \multirow[t]{2}{*}{$\begin{array}{l}\text { All outlets grounded/GFI rated available } \\
\text { where water may be present }\end{array}$} & \multirow[t]{2}{*}{ Building Services } & $\begin{array}{l}\text { Electrical } \\
\text { Grounding } \\
\text { System }\end{array}$ \\
\hline & & & $\begin{array}{l}\text { Electrical } \\
\text { Grounding } \\
\text { System }\end{array}$ \\
\hline ISR-I Component & ISR-I Sub Component & ISR-I Priority & \\
\hline Kitchenette & Cabinets and Countertops & High & \\
\hline ISR-I Rating & ISR-I Criteria & BUILDER Category & $\begin{array}{l}\text { BUILDER Sub } \\
\text { Issue }\end{array}$ \\
\hline \multirow[t]{2}{*}{ Green } & \multirow[t]{2}{*}{$\begin{array}{l}\text { ADAAG/UFAS accessible cabinets and } \\
\text { countertops are provided when space is } \\
\text { identified as ADAAG/UFAS accessible room } \\
\text { module }\end{array}$} & \multirow{4}{*}{$\begin{array}{l}\text { Accessibility } \\
\text { Missing or } \\
\text { Improper } \\
\text { Components }\end{array}$} & $\begin{array}{l}\text { ABA } \\
\text { compliance }\end{array}$ \\
\hline & & & $\begin{array}{l}\text { Missing } \\
\text { Components } \\
?\end{array}$ \\
\hline \multirow[t]{2}{*}{ Amber } & \multirow[t]{2}{*}{$\begin{array}{l}\text { ADAAG/UFAS accessible cabinets and } \\
\text { countertops are provided when space is } \\
\text { identified as ADAAG/UFAS accessible room } \\
\text { module }\end{array}$} & & $\begin{array}{l}\text { ABA } \\
\text { compliance }\end{array}$ \\
\hline & & & $\begin{array}{l}\text { Missing } \\
\text { Components } \\
?\end{array}$ \\
\hline ISR-I Component & ISR-I Sub Component & ISR-I Priority & \\
\hline Kitchenette & Appliances & High & \\
\hline ISR-I Rating & ISR-I Criteria & BUILDER Category & $\begin{array}{l}\text { BUILDER Sub } \\
\text { Issue }\end{array}$ \\
\hline \multirow[b]{2}{*}{ Amber } & \multirow[t]{2}{*}{$\begin{array}{l}\text { Include a refrigerator/freezer and } \\
\text { microwave }\end{array}$} & \multirow{2}{*}{$\begin{array}{l}\text { Missing or } \\
\text { Improper } \\
\text { Components } \\
\text { Missing or } \\
\text { Improper } \\
\text { Components }\end{array}$} & $\begin{array}{l}\text { Missing } \\
\text { Components } \\
?\end{array}$ \\
\hline & & & $\begin{array}{l}\text { Missing } \\
\text { Components } \\
?\end{array}$ \\
\hline ISR-I Component & ISR-I Sub Component & ISR-I Priority & \\
\hline Kitchenette & Doors & Medium & \\
\hline ISR-I Rating & ISR-I Criteria & BUILDER Category & $\begin{array}{l}\text { BUILDER Sub } \\
\text { Issue }\end{array}$ \\
\hline Green & ADAAG/UFAS compliant & Accessibility & $\begin{array}{l}\text { ABA } \\
\text { compliance }\end{array}$ \\
\hline
\end{tabular}




\begin{tabular}{|c|c|c|c|}
\hline Green & $\begin{array}{l}\text { Fully functional, with lever handles, push } \\
\text { plates and kick-plates }\end{array}$ & Accessibility & $\begin{array}{l}\text { ABA } \\
\text { compliance }\end{array}$ \\
\hline \multirow[b]{2}{*}{ Amber } & \multirow{2}{*}{$\begin{array}{l}\text { ADAAG/UFAS compliant } \\
\text { Lever handles, push plates, or kick plates } \\
\text { are chipped or worn }\end{array}$} & \multirow[t]{2}{*}{ Accessibility } & $\begin{array}{l}\text { ABA } \\
\text { compliance }\end{array}$ \\
\hline & & & $\begin{array}{l}\text { ABA } \\
\text { compliance }\end{array}$ \\
\hline ISR-I Component & ISR-I Sub Component & ISR-I Priority & \\
\hline Kitchenette & Ventilation & Medium & \\
\hline ISR-I Rating & ISR-I Criteria & BUILDER Category & $\begin{array}{l}\text { BUILDER Sub } \\
\text { Issue }\end{array}$ \\
\hline \multirow[t]{2}{*}{ Green } & \multirow{2}{*}{$\begin{array}{l}\text { Ventilation integrated into forced air } \\
\text { system } \\
\text { Fans provided, but not integrated into } \\
\text { forced air system }\end{array}$} & \multirow[b]{2}{*}{ Comfort } & $\begin{array}{l}\text { Ventilation } \\
\text { Capacity }\end{array}$ \\
\hline & & & $\begin{array}{l}\text { Ventilation } \\
\text { Capacity }\end{array}$ \\
\hline ISR-I Component & ISR-I Sub Component & ISR-I Priority & \\
\hline Laundry Room & Plumbing Fixtures & High & \\
\hline ISR-I Rating & ISR-I Criteria & BUILDER Category & $\begin{array}{l}\text { BUILDER Sub } \\
\text { Issue }\end{array}$ \\
\hline \multirow[t]{2}{*}{ Green } & \multirow[t]{2}{*}{ Ample hot water } & Building Services & $\begin{array}{l}\text { Hot Water } \\
\text { Supply }\end{array}$ \\
\hline & & Building Services & $\begin{array}{l}\text { Building } \\
\text { Water Supply }\end{array}$ \\
\hline Amber & Lukewarm "hot" water & Building Services & $\begin{array}{l}\text { Hot Water } \\
\text { Supply }\end{array}$ \\
\hline Amber & Low water pressure & Building Services & $\begin{array}{l}\text { Building } \\
\text { Water Supply }\end{array}$ \\
\hline \multirow[t]{2}{*}{ Red } & \multirow[b]{2}{*}{ Very low water pressure } & Building Services & $\begin{array}{l}\text { Hot Water } \\
\text { Supply }\end{array}$ \\
\hline & & Building Services & $\begin{array}{l}\text { Building } \\
\text { Water Supply }\end{array}$ \\
\hline ISR-I Component & ISR-I Sub Component & ISR-I Priority & \\
\hline Laundry Room & Lighting and Outlets & High & \\
\hline ISR-I Rating & ISR-I Criteria & BUILDER Category & $\begin{array}{l}\text { BUILDER Sub } \\
\text { Issue }\end{array}$ \\
\hline \multirow[t]{2}{*}{ Green } & \multirow[t]{2}{*}{$\begin{array}{l}\text { All outlets grounded/GFI rated available } \\
\text { where water may be present }\end{array}$} & \multirow[t]{2}{*}{ Building Services } & $\begin{array}{l}\text { Electrical } \\
\text { Grounding } \\
\text { System }\end{array}$ \\
\hline & & & $\begin{array}{l}\text { Electrical } \\
\text { Grounding } \\
\text { System }\end{array}$ \\
\hline ISR-I Component & ISR-I Sub Component & ISR-I Priority & \\
\hline Laundry Room & Washers and Dryers & High & \\
\hline ISR-I Rating & ISR-I Criteria & BUILDER Category & $\begin{array}{l}\text { BUILDER Sub } \\
\text { Issue }\end{array}$ \\
\hline Green & 1 washer and 1 dryer per room module, or & $\begin{array}{l}\text { Missing or } \\
\text { Improper } \\
\text { Components }\end{array}$ & $\begin{array}{l}\text { Missing } \\
\text { Components } \\
?\end{array}$ \\
\hline
\end{tabular}




\begin{tabular}{|c|c|c|c|}
\hline Green & $\begin{array}{l}\text { Large capacity washer and dryers in a } \\
\text { shared laundry at minimum ratio of } 8: 1 \\
\text { (washers) and } 6: 1 \text { dryers }\end{array}$ & $\begin{array}{l}\text { Missing or } \\
\text { Improper } \\
\text { Components }\end{array}$ & $\begin{array}{l}\text { Missing } \\
\text { Components } \\
?\end{array}$ \\
\hline \multirow[t]{2}{*}{ Amber } & \multirow{2}{*}{$\begin{array}{l}1 \text { washer and } 1 \text { dryer per room module, or } \\
\text { Large capacity washer and dryers in a } \\
\text { shared laundry at minimum ratio of } 8: 1 \\
\text { (washers) and } 6: 1 \text { dryers }\end{array}$} & \multirow{2}{*}{$\begin{array}{l}\text { Missing or } \\
\text { Improper } \\
\text { Components } \\
\text { Missing or } \\
\text { Improper } \\
\text { Components }\end{array}$} & $\begin{array}{l}\text { Missing } \\
\text { Components } \\
?\end{array}$ \\
\hline & & & $\begin{array}{l}\text { Missing } \\
\text { Components } \\
?\end{array}$ \\
\hline ISR-I Component & ISR-I Sub Component & ISR-I Priority & \\
\hline Laundry Room & Ventilation & High & \\
\hline ISR-I Rating & ISR-I Criteria & BUILDER Category & $\begin{array}{l}\text { BUILDER Sub } \\
\text { Issue }\end{array}$ \\
\hline Green & \multirow{3}{*}{$\begin{array}{l}\text { Dryers vent to the building exterior } \\
\text { Ventilation integrated into forced air } \\
\text { system } \\
\text { Does not meet GREEN column minimum } \\
\text { conditions }\end{array}$} & Comfort & $\begin{array}{l}\text { Ventilation } \\
\text { Capacity }\end{array}$ \\
\hline \multirow[t]{2}{*}{ Green } & & \multirow[t]{2}{*}{ Comfort } & $\begin{array}{l}\text { Ventilation } \\
\text { Capacity }\end{array}$ \\
\hline & & & $\begin{array}{l}\text { Ventilation } \\
\text { Capacity }\end{array}$ \\
\hline ISR-I Component & ISR-I Sub Component & ISR-I Priority & \\
\hline Laundry Room & Doors & Medium & \\
\hline ISR-I Rating & ISR-I Criteria & BUILDER Category & $\begin{array}{l}\text { BUILDER Sub } \\
\text { Issue }\end{array}$ \\
\hline Green & \multirow{2}{*}{$\begin{array}{l}\text { ADAAG/UFAS compliant } \\
\text { Fully functional, with lever handles, push } \\
\text { plates and kick-plates }\end{array}$} & Accessibility & $\begin{array}{l}\text { ABA } \\
\text { compliance }\end{array}$ \\
\hline Green & & Accessibility & $\begin{array}{l}\text { ABA } \\
\text { compliance }\end{array}$ \\
\hline \multirow[t]{2}{*}{ Amber } & \multirow{2}{*}{$\begin{array}{l}\text { ADAAG/UFAS compliant } \\
\text { Lever handles, push plates, or kick plates } \\
\text { are chipped or worn }\end{array}$} & \multirow[t]{2}{*}{ Accessibility } & $\begin{array}{l}\text { ABA } \\
\text { compliance }\end{array}$ \\
\hline & & & $\begin{array}{l}\text { ABA } \\
\text { compliance }\end{array}$ \\
\hline ISR-I Component & ISR-I Sub Component & ISR-I Priority & \\
\hline Laundry Room & Scrub Sinks & Medium & \\
\hline ISR-I Rating & ISR-I Criteria & BUILDER Category & $\begin{array}{l}\text { BUILDER Sub } \\
\text { Issue }\end{array}$ \\
\hline \multirow[t]{2}{*}{ Green } & \multirow{2}{*}{$\begin{array}{l}\text { Lever actuated faucet } \\
\text { Equipment scrub designated space } \\
\text { available }\end{array}$} & \multirow{2}{*}{$\begin{array}{l}\text { Accessibility } \\
\text { Size and } \\
\text { Configuration }\end{array}$} & $\begin{array}{l}\text { ABA } \\
\text { compliance }\end{array}$ \\
\hline & & & Overcrowding \\
\hline Amber & \multirow{2}{*}{$\begin{array}{l}\text { Lever actuated faucet } \\
\text { Does not meet AMBER column minimum } \\
\text { conditions }\end{array}$} & \multirow[t]{2}{*}{ Accessibility } & $\begin{array}{l}\text { ABA } \\
\text { compliance }\end{array}$ \\
\hline Red & & & $\begin{array}{l}\text { ABA } \\
\text { compliance }\end{array}$ \\
\hline
\end{tabular}




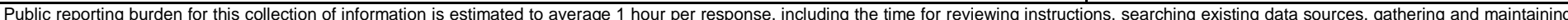

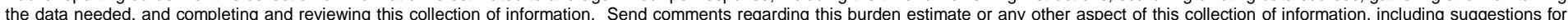

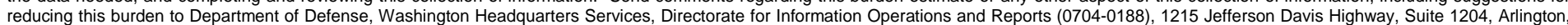

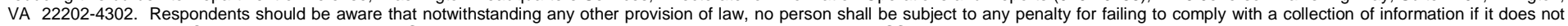
display a currently valid OMB control number. PLEASE DO NOT RETURN YOUR FORM TO THE ABOVE ADDRESS.

\section{REPORT DATE (DD-MM-YYYY) \\ September 2010}

4. TITLE AND SUBTITLE

Development of Army Facility Functionality Assessment Criteria and Procedures

\section{AUTHOR(S)}

Michael N. Grussing, Lance R. Marrano, and Matthew C. Walters r

\section{DATES COVERED (From - To)}

5a. CONTRACT NUMBER

5b. GRANT NUMBER

5c. PROGRAM ELEMENT NUMBER

ITTP

5d. PROJECT NUMBER

FY09-38

5e. TASK NUMBER

5f. WORK UNIT NUMBER

8. PERFORMING ORGANIZATION REPORT NUMBER

ERDC/CERL TR-10-17

\section{Construction Engineering Research Laboratory}

P.O. Box 9005

Champaign, IL 61826-9005

10. SPONSOR/MONITOR'S ACRONYM(S) ACSIM

Office of the Assistant Chief of Staff for Installation Management Facilities Branch (DAIM-ODF) 2511 Jefferson Davis Highway

11. SPONSOR/MONITOR'S REPORT Arlington, VA 22202 NUMBER(S)

\section{DISTRIBUTION / AVAILABILITY STATEMENT}

Approved for public release; distribution is unlimited.

\section{SUPPLEMENTARY NOTES}

\section{ABSTRACT}

This report describes the process for identifying building functionality criteria and assessing the functional capability of Army facility real property. The criteria are to be incorporated into a process to measure the functionality and performance of existing Army buildings for support of sustainment, restoration, and modernization (SRM) decisions. This process is based on a general functionality assessment framework developed for the BUILDERTM Sustainment Management System (SMS). BUILDER includes an algorithm and procedure for calculating a building functionality index (FI) based on a predefined set of criteria. The FI indicates any decrease in building performance due to technical obsolescence, user requirement changes, or new codes or standards. These generalized criteria are supplemented with Army-specific criteria based on current Army Standards and Army Standard Designs. In addition, facility functionality-related criteria from the Army Installation Status Report for Infrastructure (ISR-I) are identified and mapped to BUILDER criteria. This linkage provides a way to exchange information between ISR-I and BUILDER, creating the technical basis for an integrated facility management environment. This report presents the results of the work and offers recommendations pertaining to future integration efforts.

\section{SUBJECT TERMS}

asset management, Functionality Index (FI), Sustainment Management Systems (SMS), infrastructure, evaluation, Installation Status Report for Infrastructure (ISR-I)

\section{SECURITY CLASSIFICATION OF:}

\section{a. REPORT}

Unclassified

b. ABSTRACT
Unclassified

17. LIMITATION OF ABSTRACT
c. THIS PAGE
Unclassified

\section{NUMBER \\ 19a. NAME OF RESPONSIBLE} OF PAGES

179 PERSON

19b. TELEPHONE NUMBER (include area code) 